\title{
Bibliography of Publications
}

Relating to Ground Water

Prepared by the

Geological Survey and

Cooperating Agencies

1946-55

GEOLOGICALSURVEY WATER-SUPPLY PAPER 1492

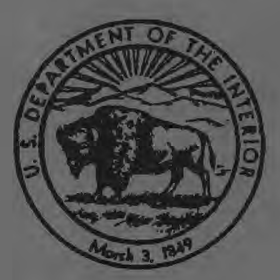




\section{Bibliography of Publications}

Relating to Ground Water

Prepared by the

Geological Survey and

Cooperating Agencies

1946-55

By ROBERT C. VORHIS

GEOLOGICAL SURVEY WATER-SUPPLY PAPER 1492

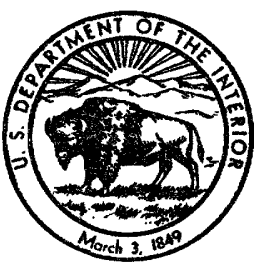




\section{UNITED STATES DEPARTMENT OF THE INTERIOR}

FRED A. SEATON, Secretary

\section{GEOLOGICAL SURVEY}

Thomas B. Nolan, Director 


\section{CONTENTS}

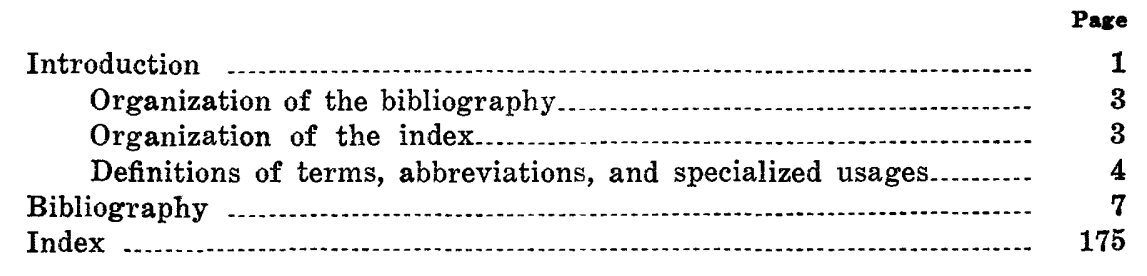

\section{ILLUSTRATION}

Figure 1. Map showing area covered by each part of the report on water levels and artesian pressures

\section{TABLE}

TABLE 1. Reports on water levels and artesian pressures in observation wells in the United States. 


\title{
BIBLIOGRAPHY OF PUBLICATIONS RELATING TO GROUND WATER PREPARED BY THE GEOLOGICAL SURVEY AND COOPERATING AGENCIES 1946-55
}

\author{
By ROBERT C. VorHIS
}

\section{INTRODUCTION}

The publications cited in this bibliography are products of the continuing systematic investigation of ground water by the United States Geological Survey. The investigations, which began on a very modest scale, have evolved from simple inventories of wells and their yields through general identification and evaluation of water-bearing formations (aquifers) to detailed quantitative studies of ground-water areas, including both those that are promising and those that have been overdeveloped. The basic authority under which ground-water investigations have been made by the Geological Survey is contained in the appropriation bills of 1902 and subsequent years. These have provided for gaging streams and determining the water supply of the United States, and for investigating: underground currents and artesian wells, and methods of utilizing the water resources. The investigations, for the most part, have been conducted within the Geological Survey by the Ground Water Branch (called the Ground Water Division until December 31, 1948). The Ground Water Branch has as its functions: (1) to determine, for all parts of the United States and its territories and island possessions, the occurrence, quantity, head, and quality of the ground water; (2) to determine the best methods of using and conserving ground water; and (3) to publish findings so that the available information for all areas can be found readily.

In fulfillment of the third function, four previous bibliographies have been published as water-supply papers by the Geological Survey. Water-Supply Paper 120 covered publications of the period 1879-1904; Water-Supply Paper 163, the year 1905; Water-Supply Paper 427, the period 1879-1918; and WaterSupply Paper 992, the period 1879-1946. All but one of these have been limited to ground-water literature written by Survey 
authors or prepared under Survey supervision. The one exception, the bibliography for 1905, was an attempt to establish an annual ground-water bibliography giving complete coverage of both Survey and non-Survey ground-water literature, including foreign papers.

The present volume is intended primarily as a guide to published ground-water literature prepared by the U. S. Geological Survey and cooperating agencies during the period 1946-55, inclusive. Though intended as a supplement to Water-Supply Paper 992, it is arranged differently so as to enable the reader to locate references on areal reports and ground-water subjects with a minimum of effort. The index serves as a guide to the literature on ground water, but not to the numerous collateral studies that are associated with ground-water investigations. For example, geology is subordinated in the abstracts and index because that subject is covered in a series of bibliographies, prepared by the Geological Survey, entitled "Bibliography of North American geology." Collateral studies, such as sections on climate, history, surface water, and glacial geology, are not indexed. Geologic maps, however, are indexed under the subheading geologic maps that appears under State names, and the location of each mapped area is indicated. Many of the maps cited are special-purpose geologic maps in that they may show such features of a formation as its top or bottom surface or its thickness.

About 950 papers are described in this volume. The Geological Survey published 107 of these as water-supply papers, 69 as circulars, 5 as hydrologic atlases, 4 as professional papers, 4 as quadrangle maps, and 125 as duplicated reports. The remainder were published by other governmental agencies, cooperating agencies, and scientific and technical organizations.

Purposely omitted from this bibliography are many reports prepared within the Ground Water Branch during the period. Such are (1) open-file reports issued in only a few copies and not readily available to the public, though many of them will be published; (2) reports dealing solely with diverse collateral subjects such as petrography, meteorites, glacial boulders, stratigraphy, oil possibilities, and tsunamis; (3) abstracts published separately from the papers they describe; (4) ground-water papers published by cooperating agencies but not prepared under a cooperative program; (5) duplicated reports superseded by formal publications; and (6) printed discussions by Survey staff members of papers written by non-Survey authors. 
This bibliography was compiled at the suggestion of, and under the general supervision of, A. N. Sayre, chief, Ground Water Branch, and under the direct supervision of C. L. McGuinness, chief of the Technical Reports Section of that Branch. Annual lists of Geological Survey ground-water reports compiled by Margaret Griffin of the Survey were used as the starting point in the preparation of this bibliography. D. W. Hastie and W. G. Dawson, reference librarians in the Geological Survey Library, have helped by locating many out-of-the-way, hard-to-find papers.

\section{ORGANIZATION OF THE BIBLIOGRAPHY}

The arrangement of the references in this bibliography is by author and is essentially similar to that now used in the "Bibliography of North American geology" and the "Bibliography of geology exclusive of North America," the latter published by the Geological Society of America. Many of the references are followed by two paragraphs, one giving a brief abstract and the other annotating the data included in the reports. The abstracts are based on examination of reports, condensation of authors' abstracts, abridgment of Survey press releases, or modification of the descriptive notes in the monthly list "New publications of the Geological Survey."

Cross references at the heads of the citations, as well as references in the index, are to the senior author. In cross references the surname of the senior author is given alone, except where there is more than one author having the same surname.

In order to give the user of the bibliography an idea as to the detail in which each area has been treated, the annotations for areal reports give the number of square miles covered and the number of well records, well logs, chemical analyses, etc., that are tabulated. For example, if chemical analyses are cited, the report probably contains a discussion of the chemical quality of the water in the area described.

The stratigraphic nomenclature used in the annotations is that used by the author or the publishing agency at the time of publication and does not necessarily conform to the current usage of the U. S. Geological Survey.

\section{ORGANIZATION OF THE INDEX}

The index is a guide both to areal reports and to reports and papers discussing particular subjects rather than areas. The areas are indexed primarily under State names or, for those few reports concerning foreign areas, under the appropriate country name. Geologic and hydrologic maps are listed under State names. 
The subjects indexed are generalized as much as possible, so that related reports can be grouped together. For example, grouped under the heading Water levels is a wide range of subjects: methods of water-level measurement, barometric and seismic fluctuations of water levels, and others.

\section{DEFINITIONS OF TERMS, ABBREVIATIONS, AND SPECIAL USAGES}

[Abbreviations used in citations are defined in "Abbreviations used in publications of the U. S. Geological Survey"]

Acre-ft. Acre-foot, a unit for measuring the volume of water, is equal to the quantity of water required to cover 1 acre to a depth of 1 foot, or 43,560 cubic feet.

Acre-ft per yr. Acre-feet per year.

Aquifer. A geologic formation, group of formations, or part of a formation that is water bearing.

Aquifer test. (also Pumping test). A test to determine the hydraulic characteristics of an aquifer by observing the effect on water levels in wells of controlled or observed changes in the forces that affect the water levels. Includes controlled pumping or recharge tests and observation of the effects of cyclic phenomena like tides.

Aquifer-test data. Used in this bibliography to indicate published data from an aquifer test in a form complete enough that the results can be recomputed or restudied.

Aquifer-test results. Used in this bibliography to indicate that the results of an aquifer test (transmissibility, $T$, and storage, $S$, values) are published without the data from which they were computed.

Cfs. Cubic feet per second, a unit for measurement of the rate of flow of water.

Chemical analyses. For the purpose of this report, chemical analyses are considered as analyses of the chemical constituents and related properties of water samples. A comprehensive chemical analysis is considered to be one in which determinations were made for at least calcium, magnesium, sodium, bicarbonate, sulfate, and chloride. A complete chemical analysis is considered to be one in which many minor constituents also were determined. A partial chemical analysis is one in which determinations were made of at least the bicarbonate, sulfate, and chloride. Where the unqualified term chemical analysis is used, comprehensive analysis is to be inferred.

Fence diagram. Two or more geologic cross sections assembled to give a three-dimensional representation.

Geologic map (interpreted broadly). A map showing one or more of the following features: areal distribution of a geologic unit or units at or below the surface, altitude of the top or other horizon of the unit, and structure or thickness of the unit.

Gpd. Gallons per day.

Gpm. Gallons per minute. 
Mgd. Million gallons per day.

Mgy. Million gallons per year.

Particle-size analysis-The data obtained by mechanical analysis, including elutriation, of granular materials.

Ppm. Parts per million.

Test-hole log. Used in this bibliography to include all logs of wells drilled specifically for test purposes and wells from which samples were collected for examination by a ground-water hydrologist.

Water-level map. Used in this bibliography for a map showing contours of the water table of an unconfined aquifer or the piezometric surface of an artesian aquifer, or both.

Well logs. As used in this bibliography, includes drillers' logs as distinguished from logs prepared by geologists and ground-water hydrologists.

Well records. As used in this bibliography, includes well data, generally in tabular form, giving well owner, depth, diameter, depth to water, aquifer penetrated, yield, use of the water, etc. 
TABLE 1.-Reports on water levels and artesian pressures in observation wells in the United States, 1944-55

\begin{tabular}{|c|c|c|c|c|c|c|}
\hline \multirow{2}{*}{$\begin{array}{c}\text { Report } \\
\text { year }\end{array}$} & \multicolumn{6}{|c|}{ Numbers of water-supply papers } \\
\hline & Part 1 & Part 2 & Part 3 & Part 4 & Part 5 & Part 6 \\
\hline 1944 & 1016 & 1017 & 1018 & 1019 & 1020 & 1021 \\
\hline $1945 \ldots$ & 1023 & 1024 & 1025 & 1026 & 1027 & 1028 \\
\hline $1946 \ldots$ & 1071 & 1072 & 1073 & 1074 & 1075 & 1076 \\
\hline $1947 \ldots$ & 1096 & 1097 & 1098 & 1099 & 1100 & 1101 \\
\hline $1948 \ldots .$. & 1126 & 1127 & 1128 & 1129 & 1130 & 1131 \\
\hline $1949 \ldots$ & 1156 & 1157 & 1158 & 1159 & 1160 & 1161 \\
\hline 1950. & 1165 & 1166 & 1167 & 1168 & 1169 & 1170 \\
\hline 1951. & 1191 & 1192 & 1193 & 1194 & 1195 & 1196 \\
\hline 1952. & 1221 & 1222 & 1223 & 1224 & 1225 & 1226 \\
\hline $1953 \ldots$ & 1265 & 1266 & 1267 & 1268 & 1269 & 1270 \\
\hline 1954 & 1321 & 1322 & 1323 & 1324 & 1325 & 1326 \\
\hline $1955 \ldots$ & 1404 & $1405^{*}$ & 1406 & 1407 & 1408 & $1409^{* * *}$ \\
\hline
\end{tabular}

*In press.

**In preparation.

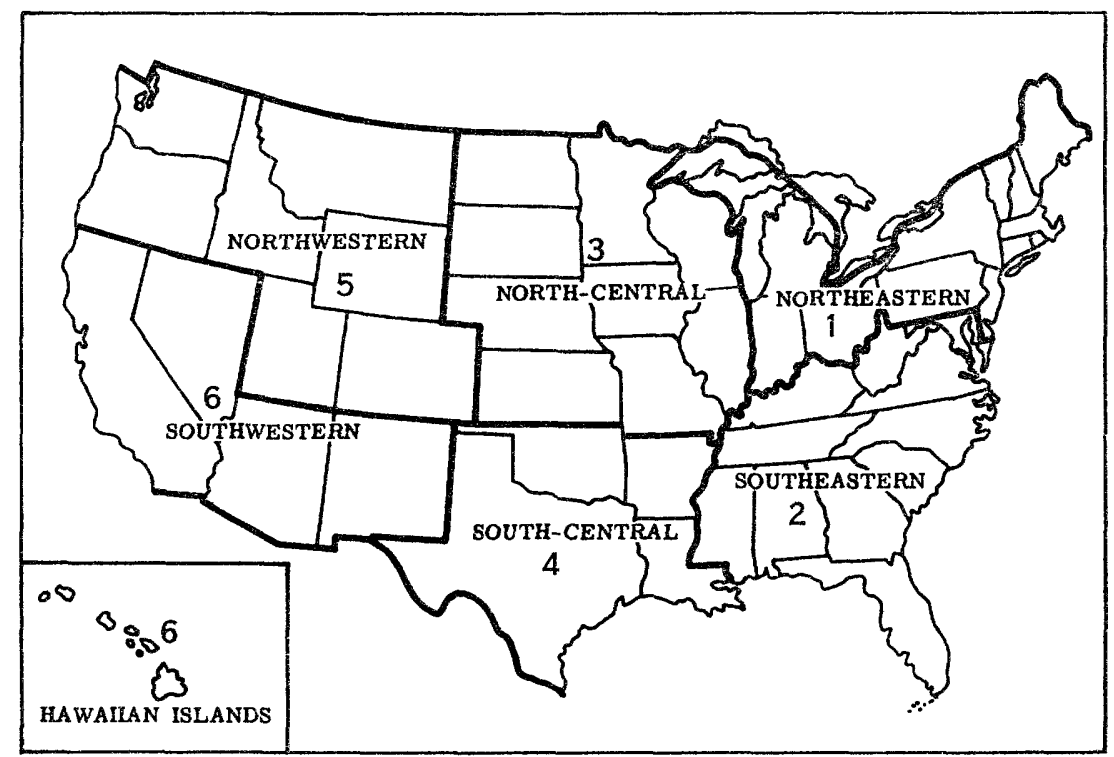

FIGURE 1.-Map showing area covered by each part of the reports on water levels and artesian pressures in observation wells in the United States, 1944-55. 


\section{BIBLIOGRAPHY}

Adamson, John H., Jr.

1947. Review of ground-water collection and development methods: Am.

Water Works Assoc. Jour., v. 39, no. 8, p. 739-746.

Describes in general terms the properties of rocks and the behavior of ground water; outlines briefly the use of springs, infiltration galleries, and wells, and artificial recharge; and discusses problems of ground-water use and studies to determine safe yield in Pennsylvania.

1949a. Ground-water significance in Pittsburgh area: Pa. Dept. Int. Affairs Monthly Bull., v. 17, no. 10, p. 26-32.

For a fuller treatment of the subject, see Adamson $49 \mathrm{~b}^{1}$.

1949b. (and Graham, J. B., and Klein, N. H.). Ground-water resources of the valley-fill deposits of Allegheny County, Pennsylvania: Pa. Topog. and Geol. Survey Bull. W8, 181 p., 5 pis., 9 figs.

The chief aquifer is glacial outwash in the Ohio and Allegheny River valleys. A less important aquifer is the nonglacial sand and gravel in the Monongahela and Youghiogheny River valleys. Away from the valleys, bedrock aquifers yield supplies adequate only for farm and domestic use.

Data include about 300 well records, 68 well logs, and 61 partial chemical analyses. A map shows the bedrock surface of the Triangle area in Pittsburgh (scale about 1:7,000).

Akin, P. Donald. See also Aronow, Saul, 53a, 53b; Conover, C. S., 42a, $42 b, 42 c$; Dennis, P. E., 49a, 49b, 50a, 50b; Laird, W. M., 48.

1942 (1953). Report on testing of water supply wells for Deming Airfield, New Mexico: N. Mex. State Engineer 14th and 15th Bienn. Repts., p. 383-417, 11 figs.

Gives logs and aquifer-test data for each of three wells drilled at Deming, N. Mex.

1946. Ground water in beach deposits of glacial Lake Agassiz near Mountain, Pembina County, North Dakota: U. S. Geol. Survey N. Dak. Ground-Water Studies 2, 27 p., 5 figs.

Deposits of beach sand are able to yield $30,000 \mathrm{gpd}$. Underflow is estimated at 50,000 gpd along a 3,000-foot line.

Data for the 3 -sq-mi area include 44 well records, 28 well logs, and maps showing water levels and the saturated thickness of sands.

1947. Geology and ground-water conditions at Minot, North Dakota: U. S. Geol. Survey N. Dak. Ground-Water Studies 6, 99 p., 12 figs.

An aquifer of glacial outwash sand and gravel in the buried valley of the Souris River is capable of yielding $3.5 \mathrm{mgd}$ without excessive lowering of pumping levels.

Data for the 14-sq-mi area include 64 well records, 7 test-hole logs, 17 well $\operatorname{logs}, 28$ chemical analyses, aquifer-test data for glacial outwash in the Souris

In the bibliography, the number that follows the author's name in a cross reference consists of the last two figures of the year of publication. 
River valley, and a geologic map (scale about $1: 21,000$ ) modified from a map by Prouty.

1950. Current ground-water work in North Dakota and Minnesota, in Proceedings of Minnesota conference on underground waters: Minn. Div. Waters Bull. 2, p. 56-59.

Reviews briefly ground-water investigations in the two States.

1951a. Ground water in the Mohall area, Bottineau and Renville Counties, North Dakota: U. S. Geol. Survey N. Dak. Ground-Water Studies 17, 76 p., 3 figs.

Alluvial deposits of sand and gravel in the valleys of intermittent streams are the only source of ground water of reasonably good quality in the Mohall area. Upper bedrock aquifers yield water of poor quality, highly charged with sodium chloride and sodium bicarbonate. Deeper bedrock formations that may be potential aquifers include the Dakota sandstones; these formations, however, probably would yield water too mineralized for general use.

Data for the 120-sq-mi area include 235 well records, $46 \mathrm{logs}$ of wells and test holes, 68 chemical analyses, 7 geological cross sections, and a geologic sketch map (scale 1:62,500).

1951b. Progress report on the geology and ground-water resoures of the Devils Lake area, North Dakota: U. S. Geol. Survey dupl. rept., 8 p., 1 fig.

This report is a generalized statement that contains no basic data.

1952a. Ground water in the Litchville area, Barnes County, North Dakota:

U. S. Geol. Survey N. Dak. Ground-Water Studies 18, 51 p., 4 figs.

Ground water is available in the Litchville area at depths of 1,000 to $1,300 \mathrm{ft}$. in the Dakota sandstone and at shallower depths in certain glacialoutwash channels, particularly in the western part of the area. The channel deposits can yield about 20,000 to $35,000 \mathrm{gpd}$ per mile of their length.

Data for the 72-sq-mi area include 148 well records, 34 test-hole logs, 19 chemical analyses, 4 geologic cross sections, and a geologic map (scale $1: 63,360)$.

1952b. (and Jones, J. R.). Geology and ground-water resources of the Cloquet area, Carlton County, Minnesota: Minn. Div. Waters Bull. 6, 63 p., 6 figs.

The chief aquifers are outwash deposits associated with the younger drift. Some glaciofluvial aquifers are included in or associated with the next older, or red, drift. No aquifers are found in the still older gray to brown drift. To exploit the ground-water resources fully, a large number of wells of relatively small individual yield spread over a large part of the township would be required.

Data for the 37-sq-mi area include more than 300 well records, 30 test-hole logs, 10 chemical analyses, results for aquifer tests of glacial outwash, a summary of results from electrical-resistivity studies, a water-level map, and an areal geologic map (scale about 1:40,000).

Alexander, W. H., Jr.

1947. Ground-water resources of San Jacinto County, Texas: Tex. Board Water Engineers dupl. rept., 29 p., 1 pl., 2 figs.

Data for the 619-sq-mi county include 123 well records, 23 well logs, 90 chemical analyses, and a cross section. The geologic map is based on the 1937 geologic map of Texas. 
1950. Ground-water resources of Liberty County, Texas, with a section on stream runoff by S. D. Breeding: U. S. Geol. Survey Water-Supply Paper 1079-A, p. 1-61, 1 pl., figs. 1-4.

Describes briefly the geology and ground-water resources of Liberty County, which is on the Gulf Coastal Plain in southeastern Texas. The Teritary and Quaternary sediments, which dip toward the Gulf, contain water under artesian pressure in all parts of the county. In areas of low altitude, such as the Trinity River valley, the pressure is sufficient to cause wells to flow. Most of the ground water is obtained from deep wells in the Lissie formation of Pleistocene age. The report contains also a brief discussion of stream runoff, including a description of daily tests of the quality of the water in the Trinity River. Temperature of ground water increases at an average rate of $1^{\circ} \mathrm{F}$ per $94 \mathrm{ft}$ of depth.

Data for the 1,173-sq-mi county include 248 well records, 92 well logs, and 145 chemical analyses.

Allen, William B. See also Cushman, R. V., 53b; Jeffords, R. M., 48b.

1948a. Ground-water resources of the Pawtucket quadrangle, Rhode Island and Massachusets, in The geology and ground-water resources of the Pawtucket quadrangle, Rhode Island: R. I. Port and Indus. Devel. Comm. Geol. Bull. 3, p. 38-85, 3 maps, 1 pl., 7 figs.

Ground-water resources of the area are far from fully utilized. The buried valleys of the Blackstone and Abbott Run drainage systems contain large volumes of permeable material and offer prospects for development of large ground-water supplies.

Data include 349 well records, 23 well logs, 18 chemical analyses, and results of an aquifer test of outwash at Ashton. Maps at a scale of 1:31,680 show outwash deposits, surficial geology (by N. E. Chute), and bedrock geology (by A. W. Quinn, R. G. Ray, and W. L. Seymour).

1948b. (and Jeffords, R. M.). Ground-water resources in the vicinity of Exeter, Rhode Island.: R. I. Port and Indus. Devel. Comm. Sci. Contr. 2, 42 p., 10 figs.

Abundant ground water satisfactory for public supply and industrial use is available from the thicker deposits of glacial sand and gravel underlying the area.

Data for the 20-sq-mi area includes 32 well records, 7 well logs, and particlesize analyses. Data are given for an aquifer test of outwash desposits at Exeter. A map shows distribution of glacial materials in the area (scale about 1:30,000).

1950a. Ground-water resources of Woonsocket, Rhode Island, in The geology and ground-water resources of Woonsocket, Rhode Island:

R. I. Port and Indus. Devel. Comm. Geol. Bull. 5, p. 18-40, 2 pls., 5 figs.

Buried valleys that pass beneath the city of Woonsocket contain large volumes of highly permeable stratified glacial drift. The underground reservoirs of these valleys are largely undeveloped and if pumped offer opportunity for induced recharge.

Data include 78 well records, 36 well $\operatorname{logss}$, and 3 chemical analyses. Maps at a scale of $1: 15,840$ show preliminary surficial geology and bedrock geology (by W. B. Allen and A. W. Quinn).

1950b. (and Blackhall, J. A.). Ground-water resources of Bristol, Warren, and Barrington, Bristol County, Rhode Island: R. 1. Port and Indus. Devel. Comm. Sci. Contr. 3, 14 p., 1 pl., 1 fig. 
Only small supplies of ground water are available. In the town of Barrington, deposits of stratified drift will yield moderate supplies of ground waterprobably not more than a total of $11 / 2 \mathrm{mgd}$.

Data include 195 well records, 8 chemical analyses, and a map of outwash deposits (scale about 1:30,000).

1951a. Ground-water resources of the Georgiaville quadrangle, Rhode Island, in The geology and ground-water resources of the Georgiaville quadrangle, Rhode Isiand: R. I. Port and Indus. Devel. Comm. Geol. Bull. 4, pt. 2, p. 31-75, pl. 3, figs. 2-7.

The buried valleys of the Branch and Woonasquatucket drainage systems are favorable for development of large ground-water supplies.

Data include 300 well records, 4 well logs, and 15 chemical analyses. Maps (scale 1:31,680) show outwash deposits (by W. B. Allen) and surficial and bedrock geology (by G. M. Richmond).

1951b. Technical investigations of additional ground-water supplies in Rhode Island: New England Water Works Assoc. Jour., v. 65, no. 3, p. 211-216, 1 fig.

Areal ground-water studies have been completed for the Pawtucket and Georgiaville 71/2-minute quadrangles and the cities of Providence and Woonsocket. Other intensive local studies are shown on an index map.

1953a. The ground-water resources of Rhode Island-A reconnaissance, with a section on surface-water resources by H. B. Kinnison: R. I.

Devel. Council Geol. Bull. 6, 170 p., 5 pls., 6 figs.

The chief aquifers are glacial-outwash deposits. Wells in sedimentary rocks have average yields 3 times as great as wells in igneous and metamorphic rocks. Wells in till yield only small supplies of water. Groundwater use in Rhode Island is about $25 \mathrm{mgd}$.

Data for the 1,058-sq-mi State include 800 well records, 100 well logs, and 102 chemical analyses. A map shows promising areas for moderate to large ground-water development. Other maps show generalized bedrock and surficial geology (scale about 1:125,000).

1953b. Ground-water studies in Rhode Island: New England Water Works Assoc. Jour., v. 67, no. 2, p. 96-113, 7 figs.

Yields as high as 2,700 gpm have been reported for wells in glacial deposits -5 times the best yield reported for wells in bedrock. An average of about $25 \mathrm{mgd}$ is pumped from wells in the State.

Anders, Robert B. See Peek, H. M., 55.

Armstrong, Clarence A. See Stearns, R. G., 55.

Arnow, Theodore. See also Perlmutter, N. M., 53.

1949. The ground-water resources of Albany County, New York: N. Y. Water Power and Control Comm. Bull. GW-20, 56 p., 2 pls., 6 figs.

Glacial deposits are the major source of ground water. The yield of wells in bedrock is small compared to that of wells in glacial or alluvial deposits.

Data for 531-sq-mi county include 286 well records, 17 spring records, 31 well logs, 30 chemical analyses, and a map of bedrock geology adapted from existing sources.

1951a. The ground-water resources of Fulton County, New York: N. Y. Water Power and Control Comm. Bull. GW-24, 41 p., 2 pls., 9 figs. 
Glacial deposits are the best aquifers in the county. An area that may be a possible source of large ground-water supplies is in the vicinity of Gloversville, where a part of the buried preglacial valley of the Sacandaga River was outlined by resistivity and seismic surveys.

Data for the 497-sq-mi county include 219 well and spring records, 14 well logs, 22 chemical analyses, 2 geologic cross sections, graphs for resistivity surveys, a seismic time-distance graph, and a geologic map of the bedrock adapted from an existing source.

1951b. The ground-water resources of Columbia County, New York: N. Y. Water Power and Control Comm. Bull. GW-25, 47 p., 3 pls., 4 figs.

The ground-water supply is sufficient to meet more than the present demands. Alluvial deposits and glacial sand and gravel are the most productive aquifers. Lebanon Warm Spring yields water of deep-seated origin rising along a fault plane. All other ground-water in the county has its source in precipitation on the immediate area.

Data for the 638-sq-mi county include 397 well and 19 spring records, 25 well logs, 24 chemical analyses, a geologic cross section, and a map of buried rock topography (scale about $1: 134,000$ ). Geologic maps of surficial deposits and bedrock are adapted from existing sources.

1954. The hydrology of the northern Marshall Island: Pacific Sci. Board Atoll Research Bull. 30, 7 p., 6 figs.

Presents observations on ground-water collected in the Marshall Islands during visits to 11 atolls. The average height of fresh water above sea level is less than $1 \mathrm{ft}$, so depth of fresh water below sea level generally is not more than $40 \mathrm{ft}$ at the deepest point.

Data include 13 chemical analyses, comparison of tides in ocean and wells, and comparison of hardness and chloride content of water, with distance from shore.

1955. The hydrology of Ifalik Atoll, Western Caroline Islands: Pacific Sci. Board Atoll Research Bull. 44, 15 p., 10 figs.

Data for the 0.6-sq-mi atoll, which is 360 nautical miles south of Guam, include records of rainfall, tide, atmospheric pressure, relative humidity, temperature, and 6 comprehensive and numerous partial chemical analyses. Hardness, chloride content, and ground-water levels are related to tides and distance from shore.

\section{Aronow, Saul}

1953a. (and Dennis, P. E., and Akin, P. D.). Geology and ground-water resources of the Minnewaukan area, Benson County, North Dakota: U. S. Geol. Survey N. Dak. Ground-Water Studies 19, 125 p., 15 figs.

Ground water is limited in amount and much is of poor quality. Glacial outwash will yield a maximum of 50 to $100 \mathrm{gpm}$, except that in a bedrock "low" under the dry lake bed east of Minnewaukan the outwash is capable of yielding water at a rate of several hundred to more than $1,000 \mathrm{gpm}$. Most wells yield hard water of generally poor quality containing objectionable amounts of sulfate, iron, and dissolved solids.

Data for the 150-sq-mi area include 137 well records, 71 test-hole and well logs, 22 chemical analyses, 8 geologic cross sections, and a geologic map (scale about 1:61,000). 
1953b. (and Dennis, P. E., and Akin, P. D.). Geology and ground-water resources of the Michigan City area, Nelson County, North Dakota: U. S. Geol. Survey N. Dak. Ground-Water Studies 21, 125 p., 8 figs.

The surface material in the area is glacial drift and the immediately underlying bedrock is the Pierre shale. Both yield water, but only in small quantities. Water in larger quantities could be obtained from the Dakota formation at depth of 1,200 to $1,300 \mathrm{ft}$, but it would be highly mineralized and unsuitable for general use.

Data for the 112-sq-mi area include 275 well records, .65 test-hole and well logs, 25 chemical analyses, 5 geologic sections, results of aquifer tests on both glacial outwash and the Pierre shale, and a geologic map (scale about 1:55,000).

\section{Asselstine, Erwin S.}

1946. Progress report on ground-water conditions in the Cortland quadrangle, New York: N. Y. Water Power and Control Comm. Bull. GW16,49 p., 2 pls., 2 figs.

Sufficient water for domestic needs can be obtained anywhere in the county from wells in bedrock. Larger supplies are available only from sand and gravel deposits in the valleys.

Data for the 200-sq-mi area include 97 well records and 15 chemical analyses.

1955. (and Grossman, I. G.). The ground-water resources of Westchester County, New York; part 1, records of wells and test holes: N. Y. Water Power and Control Comm. Bull. GW-35, 79 p., 3 pl., 1 fig.

Contains brief description of the consolidated bedrock and unconsolidated surficial deposits which together are the source of all ground water in Westchester County.

Data includes logs of 96 wells and borings and well records for more than 1100 wells.

\section{Austin. Gene M.}

1954. Records of wells in Bastrop County, Texas: Tex. Board Water Engineers Bull. 5413, 43 p., 1 pl.

Data for the 885 -sq-mi county include 515 well records, 25 well logs, 111 chemical analyses, and periodic measurements of depth to water in 14 wells.

Babcock, Horace M. See also Halpenny, L. C., 47a; Rapp, J. R., 53b; Visher, R. N., 53.

1947a. (and Brown, S. C.). Ground-water resources of Peeples Valley, Arizona: U. S. Geol. Survey dupl. rept., 13 p., 1 pl.

Peeples Valley occupies a basin formed in the hard rocks of the Weaver Mountains. The outlet of the valley was dammed by a lava flow that created a deep lake. The deposits that eventually filled the lake are generally permeable and are the major aquifer.

Data include 38 well records, 19 chemical analyses, and a geologic map (scale about 1:58,000).

1947b. (and Brown, S. C., and Hem, J. D.). Geology and ground-water resources of the Wellton-Mohawk area, Yuma County, Arizona: U. S. Geol. Survey dupl. rept., 22 p., 2 pls., 2 figs.

The area is a flat desert plain that extends about 40 miles along the Gila River. The chief aquifer is the younger alluvial fill, but its water is highly 
mineralized and most of it is considered injurious to unsatisfactory for irrigation.

Data for the 700-sq-mi area include 21 well records, 17 well logs, 11 chemical analyses, and maps showing distribution of dissolved solids in the water of the alluvial fill, water level, and geology (scale about 1:150,000). For more recent reports, see Babcock $48 \mathrm{~b}$ and Halpenny 52.

1947c. (and Snyder, C. T.). Ground-water resources of the Holbrook area, Navajo County, Arizona, with a section on quality of water by

J. D. Hem: U. S. Geol. Survey dupl. rept., 27 p., 3 pls.

Water from precipitation percolates into the Coconino sandstone and moves generally northeast where it is discharged through springs and wells. The main discharge area is south of the river between Holbrook and Joseph City; total measured discharge in 1946 was 4,300 acre-ft.

Data for the 3,200-sq-mi area include 49 well records, 9 well logs, 35 chemical analyses, and maps showing artesian area along the Little Colorado River, distribution of dissolved solids in water in the Coconino sandstone, and areal geology (scale about 1:380,000).

1948a. Memorandum on ground-water supply of the Joseph City irrigation district (Arizona): U. S. Geol. Survey dupl. rept., 9 p., 1 fig.

The chief aquifer is the Coconino sandstone, which is recharged in the area to the south along the Mogollon Rim. Results of three aquifer tests on this sandstone indicate that the maximum annual requirement of 3,720 acre-ft can be developed.

1948b. (and Kendall, K. K.). Geology and ground-water resources of the Gila Bend basin, Maricopa County, Arizona, with a section on quality of water by J. D. Hem: U. S. Geol. Survey dupl. rept., 26 p., 3 pls.

The basin is a wide, gently sloping desert plain where ground water is being developed for irrigation. Chief aquifers are the gravel and sand deposits of the older and younger valley fill and, to a lesser degree, the sandstone beds of the fanglomerate unit.

Data for the 800 -sq-mi area include 15 well records, 9 well logs, 11 chemical analyses, and a geologic map (scale about 1:150,000). For a more recent report, see Halpenny 52.

1948c. (and Sourdry, A. M.). Wellton-Mohawk area, Yuma County, Arizona, records of wells, well logs, water analyses, and maps showing locations of wells: U. S. Geol. Survey dupl. rept., 39 p., 1 pl.

Data for the 700 -sq-mi area include 150 well records, 79 well $\operatorname{logs}, 78$ chemical analyses, and a geologic map (scale about 1:150,000). For a more recent report, see Halpenny 52.

1951. (and Visher, F. N.). Ground-water conditions in the Dutch Flats area, Scotts Bluff and Sioux Counties, Nebraska, with a section on chemical quality of the ground water by W. H. Durum: U. S. Geol. Survey Circ. 126, 51 p., 2 pls., 10 figs.

A rise in the water table due to excessive recharge in the terrace deposits that underlie the Dutch Flats area, Nebraska, has caused waterlogging of low ground. Lining the canals and laterals and applying less water to the land would reduce the amount of recharge, and installing more drains and pumping additional water from the ground-water reservoir would increase the amount of discharge. Pumped water could be used for irrigation, which would reduce the amount of surface water needed in the area. Lowering the water 
table would reduce but not necessarily eliminate seepage in the part of the area where a partly buried ridge of the Brule formation is present. The ground water is hard and siliceous but is moderately low in mineral content. It is satisfactory for both irrigation and domestic use.

Data for the 60-sq-mi area include 75 well records, 16 well logs, periodic water-level measurements, and 10 chemical analyses. Maps show water levels, depth to water, and geology (scale 1:63,360).

1952a. (and Rapp, J. R.). Reconnaissance of the geology and groundwater resources of the Horse Creek-Bear Creek area, Laramie and Goshen Counties, Wyoming, with a section on chemical quality of the water by W. H. Durum: U. S. Geol. Survey Circ. 162, 28 p., 1 pl., 10 figs.

The Brule formation and Arikaree sandstone yield small quantities of water to wells and springs. Alluvium, which underlies the principal stream valleys, yields water readily to wells. Water in the alluvium is unconfined and in places occurs in quantities sufficient for irrigation. In the eastern part of the area irrigation wells yielding 450 to $900 \mathrm{gpm}$ obtain water from the alluvium; additional wells having comparable yields could be developed in this vicinity and in other places along Horse and Bear Creeks. Water in the alluvium and Arikaree sandstone is principally of the calcium bicarbonate type; water in the Brule formation is essentially of the sodium bicarbonate type. Although hard, the ground water is generally satisfactory for domestic use, and most of the samples rated excellent to good for irrigation. The exceptions were samples of water from the Brule formation: this water, if used at all, should be applied only to well-drained land. Data for the 1,000sq-mi area include 92 well records, 10 well logs, 11 chemical analyses, and a geologic map (scale 1:125,000).

1952b. (and Visher, F. N.). Reconnaissance of the geology and groundwater resources of the Pumpkin Creek area, Morrill and Banner Counties, Nebraska, with a section on chemical quality of the water by W. H. Durum: U. S. Geol. Survey Circ. 156, 30 p., 1 pl., 8 figs.

Discusses ground-water potentials for irrigation. The Brule, Arikaree, and Ogallala formations and alluvium are exposed in this area. The alluvium, which underlies the flood plains of Pumpkin Creek and its major tributaries, is the principal aquifer in the area, and an aquifer test was made on it. In most places, yields of 1,000 to $2,000 \mathrm{gpm}$ probably could be obtained from properly constructed wells in this aquifer. The Ogallala formation yields water to domestic and stock wells in the upland area south of the Pumpkin Creek valley. About 21,300 acre-ft of ground water leaves the area annually as streamflow and is roughly the amount of additional ground water available for development. Cost of pumping is discussed.

Data for the 400-sq-mi area include 83 well and spring records, 26 well logs, 30 chemical analyses, periodic water-level measurements, and a geologic map (scale about $1: 125,000$ ).

Bach, W. Kenneth. See Swenson, F. A., 51.

Baker, J. A.

1955. Geology and ground-water resources of the Paintsville area, Kentucky: U. S. Geol. Survey Water-Supply Paper 1257, 123 p., 3 pls., 10 figs.

The Paintsville area lies in the eastern Kentucky coalfield. The freshwater aquifers include the Lee and Breathitt formations of Pennsylvanian 
age, and Quaternary alluvium. Rocks older than Pennsylvanian yield salty water.

Data for the 60 -sq-mi area include 1,020 well records, 17 well logs, 53 chemical analyses, 4 measured geologic sections, results of "slug" aquifer tests on the Breathitt and Lee formations, 3 geologic cross sections, and a map (scale $1: 31,680)$ showing areal geology and top of the Lee formation.

Baker, Roger C. See also Hale, H., 47; Hewitt. F. A., 49; Klein, Howard, 50 ; Searcy, J. K., 52 ; Tait, D. B., 53.

1948. (and Hewitt, F. A., and Billingsley, G. A.). Ground-water resources of the El Dorado area, Union County, Arkansas: Ark. Univ.

Bur. Research, Research Ser. 14, 39 p., 6 figs.

The chief aquifer is a 200-ft zone in the Sparta sand at a depth of 550 to $650 \mathrm{ft}$ below land surface at El Dorado. Pumpage from it was $10.6 \mathrm{mgd}$ in 1947. Other important aquifers are the "lignitic" sand of the Cockfield formation and the "greensand" in the upper part of the Sparta sand.

Data for the 360-sq-mi area include 7 chemical analyses, aquifer-test results for Sparta sand, and pumpage data. Illustrations include a geologic cross section and a geologic map (scale about 1:500,000).

1950. An occurrence of saline ground water on Guadalcanal: Am. Geophys. Union Trans., v. 31, no. 1, p. 58-60, 1 fig.

On Guadalcanal, wells drilled between the Lunga and Nalimbu Rivers disclosed salty ground water, which probably is connate.

1955. Arkansas' ground-water resources: Ark. Geol. and Conserv. Comm. Water Res. Circ. 1, 16 p., 8 figs.

Ground-water use in Arkansas in $\mathbf{1 9 5 2}$ is estimated at 865 mgd. About 90 percent is pumped from aquifers in the Coastal Plain.

Maps show areas of chief aquifers, yields, depth to water in the Coastal Plain, water-level decline in the Grand Prairie region (1915-53), and waterlevel change in eastern Arkansas (1938-53).

Barclay, Joseph E. See also Reed, E. W., 52b.

1952. Origin of the Drummond Flat, Garfield County Oklahoma: Okla. Acad. Sci. Proc., v. 33, p. 197-198.

Author suggests that the unusually large flat and the peculiar drainage pattern on it are due to the filling of a lake whose basin was produced by collapse of near-surface rocks after the removal by solution of salt, limestone, or gypsum from the underlying bedrock

1953 (1955). (and Burton, L. C.). Ground-water resources of the terrace deposits and alluvium of western Tillman County, Oklahoma: Okla. Div. Water Res. Bull. 12, 71 p., 6 pls., 6 figs.

The chief aquifers are stream-laid terrace deposits, which average about $42 \mathrm{ft}$ thick, and alluvium, which averages about $34 \mathrm{ft}$ thick. "Safe yield" of the terrace deposits is roughly $100 \mathrm{gpm}$ per sq mi.

Data for the 285-sq-mi area include 175 selected well records, 72 test-hole $\log \mathrm{s}, 45$ well logs, 17 chemical analyses, and results for aquifer tests of terrace deposits. Maps (scale 1:100,000) show water levels, thickness of terrace deposits and alluvium, bedrock surface, and areal geology.

Barksdale, Henry C. See also Herpers, Henry, 51.

1946. (and DeBuchananne, G. D.). Artificial recharge of productive ground-water aquifers in New Jersey: Econ. Geology, v. 41, no. 7, p. 726-737, 3 figs. 
Artificial recharge by water spreading is practiced at five localities in New Jersey. Most are in areas where wells tap aquifers in their intake area so that water artificially recharged can percolate rather directly down to the wells. Deposition of silt decreased the recharge rate at East Orange from 170,000 to $130,000 \mathrm{gpd}$ per acre in a period of 8 years.

1949. Depletion of ground water in New Jersey: Am. Water Works Assoc. Jour., v. 41, no. 6, p. 511-515.

Ground-water resources of New Jersey have not been depleted on a large scale but some serious local conditions exist. Ground-water supplies are seriously depleted in the Rahway River valley and the Newark area, and salt-water encroachment is endangering the Atlantic City, Cape May, and Parlin water supplies.

1952. Ground water in the New Jersey Pine Barrens area: Bartonia, no. 26, p. $36-38$.

The sandy aquifers in the Pine Barrens area of the Coastal Plain in southern New Jersey are capable of yielding large quantities of water. The large infiltration and storage capacities of these aquifers make surface reservoirs generally unnecessary, which is fortunate because such reservoirs would be large and shallow and would lose heavily by evaporation.

1953. (and Jones P. H.). Availability of ground water in lower Delaware basin: Pa. Dept. Int. Affairs Monthly Bull. v. 21, no. 2, p. 3-10, 26, 2 figs.

Reviews occurrence, withdrawals, and use of ground water in the 11-county area around Philadelphia. A map shows the water-yielding ability of aquifers.

1955a. (and Lang, S. M.). Ground water in the Delaware River valley: Am. Soc. Civil Engineers Proc., v. 81, separate 593, 8 p.

Consolidated rocks of the upper Delaware River valley yield small to moderate ground-water supplies, but great care should be taken in the spacing of wells to reduce interference. The ground water in some of these rocks may be fairly hard and moderately high in dissolved solids.

Coastal Plain formations yield moderate to large ground-water supplies. The largest ground-water yields are obtained where Coastal Plain aquifers crop out along the Delaware River. The waters are of good overall quality except locally where contaminated by industrial wastes or by recharge from mineralized or polluted surface waters.

1955b. (and Remson, Irwin). Effect of land-management practices on ground water: Internat. Union Geodesy and Geophysics, Internat. Assoc. Sci. Hydrology, Rome, 1954, v. 2, p. 520-525.

The effect of land-management practices on the available supply of ground water depends upon the geology, topography, soils, and climate of an area. Subject to these controls, land-management practices may affect significantly the ground-water recharge, storage, and disharge.

Barnes, B. A. See also George, W. O., 45.

1947. (and Livingston, Penn). Value of the electrical log for estimating ground-water supplies and the quality of the ground water: Am. Geophys. Union Trans., v. 28, no. 6, p. 903-911, 5 figs.

Describes briefly the use of electric logs for estimating quantity and quality of ground-water supplies. The logs interpreted are from the Coastal Plain in Texas, where the rocks consist mostly of clay, sandy clay, and shale interbedded with sand and sandstone. 
Barnes, Jack R. See also Goines, W. H., 51.

1948. Ground-water resources of Wharton County, Texas: Tex. Board Water Engineers dupl. rept., 80 p., 3 pls., 1 fig.

Data for the 1,079-sq-mi county include 399 well records, 82 well logs, 11 facsimilies of electric logs, periodic water-level measurements, and 155 chemical analyses. The geologic map is based on the 1937 geologic map of Texas.

1949. (and Ellis, W. C., Leggat, E. R., Scalapino, R. A., and George, W. 0.). Geology and ground water in the irrigated region of the southern High Plains in Texas, with a section on quality of water by Burdge Irelan: Tex. Board Water Engineers Prog. Rept. 7, 51 p., 7 pls., 32 figs.

The rate of ground-water development in the southern High Plains in Texas during the past decade is believed to be unsurpassed in any comparable area in the United States. About 10,000 wells were used in 1948 to irrigate more than a million acres of cropland. The rate of pumping so exceeds the rate of recharge that the withdrawal may be considered as coming essentially from storage. If present trends in pumping and decline in water level continue, some localities may be seriously affected in 5 to 10 years. In other, larger areas where wells are widely spaced, the declines of water levels to date are small. The chief aquifer is the Ogallala formation.

Data include physical properties of 8 sand samples from the Ogallala formation, and periodic water-level measurements. Maps of water-level decline are shown for the periods March 1938 to March 1949 and March 1948 to March 1949.

Barraclough, Jack T. See also Heath, R. C., 54a.

1953. Records of wells in western Jefferson County, Idaho. U. S. Geol. Survey dupl. rept., 54 p., 1 pl., 2 figs.

Data for the 630-sq-mi area include 242 well records and 23 well logs.

Bayne, C. K. See Williams, C. C., 46 a.

Bennett, Robert Raymond. See also Meyer, R. R., $55 \mathrm{a}$.

1946b. Ground water in the Baltimore area, Maryland: Md. Dept. Research and Education Educ. ser. 13, 15 p., 2 figs.

The Patuxent and Patapsco formations in the Baltimore area yield about $40 \mathrm{mgd}$. A large part of the Patapsco formation and Pleistocene sediments, and some parts of the Patuxent formation, have been contaminated by the infiltration of salt and acidic waters. The Patuxent and a part of the Patapsco are being further contaminated through leaky wells, which should be repaired by cementing.

For a later, more comprehensive report on the Baltimore area, see Bennett $52 b$.

1946a. Ground-water resources, in The physical features of Carroll County and Frederick County: Md. Dept. Geology, Mines, and Water Res., p. 165-187.

The counties lie in parts of four ground-water areas: the Blue Ridge, Triassic, Frederick Valley limestone, and eastern Piedmont areas. Small to moderate supplies are generally available in the Triassic and Piedmont areas, and small to meager supplies in the Blue Ridge. Conditions are spotty in the Frederick Valley limestone area, there being a few large-yielding wells but also some failures.

Data for the 1,120-sq-mi area include 420 well records. 
1952. (and Meyer, R. R.). Geology and ground-water resources of the Baltimore area, Maryland: Md. Dept. Geology, Mines, and Water Res. Bull. 4, 573 p., 26 pls., 30 figs.

The chief aquifers are the Patuxent and Patapsco formations, which consist mainly of irregular beds of sand, gravel, and clay dipping gently and thickening progressively to the southeast. The two aquifers are separated by the Arundel clay. Ground water in the area has a normally low mineral content, but heavy pumping has caused local encroachment of salt water; defective wells have permitted contaminated water to move downward into fresh water, and industrial wastes have caused local contamination with chromium and sulfuric acid. Pumpage in the industrial area is limited by the transmissibility of the formations and not by the potential rate of recharge. Safe yield, methods of well construction and repair, and methods of testing for salt-water encroachment are discussed.

Data for the 200-sq-mi area include 1,450 well records, 23 test-hole logs, 307 well logs, chemical analyses and chloride determinations, water-level measurements, pumpage figures, and heavy-mineral studies. Illustrations include block diagrams, a fence diagram, and geologic cross sections. Maps show chloride contamination, water levels in Patuxent and Patapsco formations, ground-water flow lines, top of Arundel clay, bedrock surface, and thickness of Pleistocene deposits. Graphic diagrams for 2 test holes include the following data: driller's log, sample log, drilling-time log, electric log, caliper log, mud-salinity log, and, for selected beds, permeability and histograms of particle-size analyses. The geologic map is taken from existing maps.

\section{Berdan, Jean M.}

1948. Hydrology of limestone terrane in Schoharie County, New York: Am. Geophys. Union Trans., v. 29, no. 2, p. 251-253, 3 figs.

The effects of solution on Devonian and Upper Silurian carbonate rocks are well displayed in Schoharie County because the outcrop belt is relatively wide. A brief discussion of types of caverns is given.

1950. The ground-water resources of Schoharie County, New York: N. Y. Water Power and Control Comm. Bull. GW-22, 61 p., 2 pls., 4 figs.

Moderately large supplies of ground water may be available from sand and gravel deposits in Catskill Valley and the Manorkill and Jefferson areas. Cobleskill Valley and most of Schoharie Valley contain extensive clay deposits laid down in glacial lakes and it is unlikely that large supplies can be developed. Drilled wells in bedrock in the southern three-quarters of the county yield an average of $15 \mathrm{gpm}$.

Data for the 620-sq-mi area include 332 well and spring records, 45 well logs, 34 chemical analyses, and a geologic map (scale about 1:125,000) adapted in part from existing sources.

1955. The ground-water resources of Greene County, New York: N. Y.

Water Power and Control Comm. Bull. GW-34, 62 p., 3 pls., 5 figs.

The chief aquifer is the Catskill formation, which underlies the western five-sixths of the county. The average yield of wells drilled into it is $20 \mathrm{gpm}$, whereas yields of wells in the other bedrock formations average no more than $10 \mathrm{gpm}$. Sand and gravel are not widespread but wells in them yield an average of $22 \mathrm{gpm}$.

Data for the $653-$ sq-mi county include 315 well and 20 spring records, 45 
well logs, and 49 chemical analyses. Maps show bedrock and surficial geology, adapted from published sources.

Bernhagen, Ralph J. See also Van Tuyl, D. W., 47.

1947. (and Schaefer, E. J.). Ground-water conditions in Butler and Hamilton Counties, Ohio, 1946: Ohio Water Res. Board Bull. 8, 35 p., 13 pls.

Ground-water conditions are described for 9 localities in an area of heavily pumped glacial outwash: Middletown, Miami Valley between Middletown and Hamilton, Hamilton, Fairfield Township, Miami and Whitewater Valleys, Mill Creek valley, Norwood Trough, Little Miami Valley, and Ohio River valley.

Data include water-level measurements, cross sections, and a water-level map of the Hamilton area.

Berry, Delmar W.

1952. Geology and ground-water resources of Lincoln County, Kansas: Kans. Geol. Survey Bull. 95, 96 p., 7 pls., 12 figs.

Alluvial fill of valleys yields potable water adequate for domestic and stock use. Sandstones in the Dakota formation yield supplies of variable quality and quantity.

Basic data for the 726-sq-mi area include 175 well records, 43 test-hole logs, water-level data, 28 comprehensive chemical analyses, and 88 analyses for chloride and nitrate. Interpretive data include a water-level map for the Saline River valley, a depth-to-water map, distribution of chloride and nitrate, relation of fluoride to depth in Dakota formation, 6 geologic cross sections, and a geologic map (scale 1:85,000).

1955. Reconnaissance of the geology and ground-water resources of the Cokeville area, Lincoln County, Wyoming: U. S. Geol. Survey dupl. rept., 11 p., 1 fig.

Wells yielding as much as $200 \mathrm{gpm}$ can be obtained from saturated alluvium as much as $150 \mathrm{ft}$ thick that underlies Bear River valley.

Data for the 60-sq-mi area include 5 well records, 3 well logs, and a geologic map (scale 1:63,360).

Bierschenk, William $\mathbf{H}$.

1954. Ground-water resources of the Bristol quadrangle, Rhode Island and Massachusetts: R. I. Devel, Council Geol. Bull. 7, 98 p., 3 pls., 7 figs.

Development of large supplies of ground water in the Bristol quadrangle appears to be possible only in the Barrington area, where the outwash deposits are thick and locally very permeable. In Warren, Bristol, Portsmouth, and Warwick, conditions do not favor development of more than small supplies.

Data include 215 well records, 50 test-hole logs, and 17 chemical analyses. Data are given for an aquifer test of outwash at Barrington. A map shows outwash deposits (scale 1:31,680); geologic sections through Barrington show position of bedrock surface and lithology of unconsolidated deposits.

Billingsley. G. A. See Baker, R. C., 48; Counts, H. B., 55; Hale, H., 47; Hewitt, F. A., 49; Klein, H., 50; Robinson, W. H., 53; Tait, D. B., 53.

Blackhall, J. A. See Allen, W. B., $50 \mathrm{~b}$. 
Blankenship, Reginald R. See Schneider, Robert, 50.

Bluhm, Floyd I. See also McDonald, H. R., $47 \mathrm{~b}$.

1949. (and Wolcott, H. N.). Ground-water resources of Deer Valley, Maricopa County, Arizona, with a section on quality of water by J. D. Hem: U. S. Geol. Survey dupl. rept., 34 p., 3 pls., 2 figs.

The aquifers are discontinuous layers and lenses of sand and gravel in alluvial fill. Depth to water ranges from $150 \mathrm{ft}$ near the Arizona Canal to more than $300 \mathrm{ft}$ in the northern part of the area. In 1948 the average pumping lift was $270 \mathrm{ft}$, average well discharge was $1,700 \mathrm{gpm}$, and average specific capacity was $\mathbf{5 0} \mathrm{gpm}$ per $\mathrm{ft}$ of drawdown. Lowering of water levels has changed the natural direction of flow and water now moves radially into the area. Specific yield of the alluvium is between 8.2 and 11.3 per cent.

Data for the 600-sq-mi area include 110 well records, 13 well logs, and 61 chemical analyses. Maps show water levels, depth to water, water-level decline, chloride distribution in alluvial fill, and areal geology (scale about $1: 80,000)$.

Bodle, R. R.

1945. Earthquake fluctuations in wells, in United States earthquakes, 1943 : U. S. Coast and Geodetic Survey Serial 672, p. 23-26.

Data for seismic water-level fluctuations in 1943 are given for U. S. Geological Survey observation wells in Florida, Louisiana, Mississippi, and Utah.

1946. Earthquake fluctuations in wells in United States earthquakes, 1944: U. S. Coast and Geodetic Survey Serial 682, p. 25-26.

Data for seismic water-level fluctuations in Florida observation wells of the U. S. Geological Survey are listed for the period January-October 1944. Also listed are disturbances recorded at stream-gaging stations in New York State resulting from the St. Lawrence Valley quake of Sept. 5, 1944.

Bodhaine, G. L. See Mundorff, M. J., 54.

Bogart, Dean B. See Parker, G. G., 55c.

Boggess, Durwald H. See also Coskery, O. J.. 56.

1955. (and Coskery, O. J.). Water levels and artesian pressures in Delaware, 1953: Del. Geol. Survey Water-Level Rept. 2, 10 p., 2 figs. This is an advance release of the data included in the Delaware section of the annual water-level report (see table 1 and figure 1 ).

\section{Bradley, Edward}

1955. Summary of the ground-water resources of the Laramie River drainage basin, Wyoming, and the North Platte River drainage basin from Douglas, Wyoming, to the Wyoming-Nebraska State Line: U. S. Geol. Survey dupl. rept., 11 p., 1 fig.

Geologic and hydrologic data are generally sufficient to delineate those parts of the report area where large supplies of ground water can be developed. Well-site selection, however, should be based on test drilling. The ground-water potential of the Paleozoic and Mesozoic formations remains undetermined.

\section{Bramkamp, Richard}

1948. (and Brown, G. F.). Ground water in the Nejd, Saudi Arabia: N. Y. Acad. Sci. Trans., 2d ser., v. 10, no. 7, p. 236-237. ' i 
Ground-water solution of anhydrite has caused slumping in a collapsed zone several kilometers wide and 900 kilometers long. The east side of the slumped zone is marked by a cliff, where the collapse of caves has caused the formation of pits as much as $\mathbf{1 0 0}$ meters deep. Water in the pits is currently saturated with calcium sulfate, and the rate of retreat of the cliff toward the east is believed to be a function of the rate at which unsaturated ground water reaches the anhydrite face.

Branch, John R. See Prescott, G. C., 54.

Brannock, W. W. See also White, D. E., 48, 50, 53.

1948. (and Fix, P. F., Gianella, V. P., and White, D. E.). Preliminary geochemical results at Steamboat Springs, Nevada: Am. Geophys. Union Trans., จ. 29, no. 2, p. 211-226, 12 figs.

The springs seem to be structurally related to faults and genetically related to the magmatic source of recent volcanic domes of pumiceous rhyolite. Many of the springs are at or near the boiling point; the geothermal gradient near the surface is very high, commonly exceeding $1^{\circ} \mathrm{F}$ per foot of depth. Water analyses indicate a parent saline water diluted to varying degrees by meteoric water of low concentration at some unknown depth below the surface. Heavy rains have marked effects on the discharge, salinity, and temperature. The discharge responds to changes in atmospheric pressure, but artesian conditions are either obscured or absent. The acidity or alkalinity of the waters appears to be related to the temperature of the springs, the most alkaline waters tending to occur in the springs and wells of highest temperature. The springs deposit sediment containing antimony, quicksilver, gold, and silver.

Branson, Carl C. See Reed, E. W., 55.

Brashears. Maurice L., Jr. See also de Laguna, Wallace, 46.

1946. Artificial recharge of ground water on Long Island, New York: Econ. Geology, v. 41, no. 5, p. 503-516, 7 figs.

Further overdevelopment of ground water on Long Island has been essentially prevented since 1933 by a conservation policy, based on State law, requiring return to the ground of water pumped for cooling and other noncontaminating uses from new wells having capacities greater than $70 \mathrm{gpm}$. The cone of depression in Brooklyn, N. Y., continued to enlarge until near the end of 1941; since then water levels have gradually recovered. During the summer of 1944, more than 200 recharge wells and recharge pits were returning water at a rate of $60 \mathrm{mgd}$.

1949a. Bibliography of geology and ground-water conditions on Long Island, in Mapping of geologic formations and aquifers of Long Island, New York: N. Y. Water Power and Control Comm. Bull. GW-18, p. 207-212.

This report includes 69 references.

1949b. (and others). Report of committee for survey of ground water in New England: New England Water Works Assoc. Jour., v. 63, no. 2, p. 175-200.

Data on public ground-water supplies in the New England States are presented. These include maximum depth of well in each State, types of water supplies used, and types of new wells developed since 1922. Tables give well records and quality data for more than 300 water systems. 
Briggs, Revoe C.

1955. (and Troxell, H. C.). Effect of Arvin-Tehachapi earthquake on spring and stream flow, in Earthquakes in Kern County, Calif., during 1952: Calif. Div. Mines Bull. 171, p. 81-97, 19 figs.

Flow in many of the streams and springs in the area covered by this report increased as a result of the Arvin-Tehachapi earthquake of July 21, 1952. Although this increase in flow appears to have been temporary, there was still evidence of it in some of the streams and springs as late as June 1953, when the report was prepared. It is doubtful if the earthquake had any permanent effect on the recharge areas or on the permeability of the aquifers. The temporary increase in some cases is probably due to the mere disturbance of the unconsolidated material in the discharge areas, resulting in the clearing of the existing outlets and opening of new ones.

Broadhurst, S. D. See LeGrand, H. E., $55 \mathrm{~b}$.

Broadhurst, William L. See also Dale, O. C., 53; Sundstrom, R. W., 48c, $49 \mathrm{a}$.

1946. Ground water in the High Plains of Texas: Tex. Board Water Engineers Prog. Rept. 6, 31 p., 10 figs.

Consists almost entirely of basic data and discussion of water-level trends. For a later report, see Barnes 49.

1950a. Ground-water resources of Gregg County, Texas, with a section on stream runoff by S. D. Breeding: U. S. Geol. Survey Water-Supply Paper 1079-B, p. 63-105, figs. 5-6.

This paper gives a general discussion of the geology of the area in relation to ground water and, in detail, the ground-water resources in different parts of the area. Runoff data are given for the Sabine River at Gladewater and Longview. Chief aquifers are sands of the Wilcox group, Carrizo sand, and Mount Selman formation.

Data for the 284-sq-mi county include 89 well records, 50 well $\operatorname{logs}$, and 98 chemical analyses. A geologic map is based on the 1937 geologic map of Texas.

1950b. (and Sundstrom, R. W., and Rowley, J. H.). Public water supplies in southern Texas: U. S. Geol. Survey Water-Supply Paper 1070, 114 p., 1 pl.

This report describes the public water supplies in 42 counties of southern Texas, extending from the Rio Grande northward to the northern boundaries of Kinney, Uvalde, Bandera, Kendall, and Hays Counties and eastward to the eastern boundaries of Caldwell, Gonzales, De Witt, Victoria, and Calhoun Counties. Of the 114 public supplies described, 79 use ground water. The use of water for public supply averaged $95 \mathrm{mgd}$, of which $55 \mathrm{mgd}$ was ground water.

For type of data included, see Sundstrom 48a.

1951a. Ground water in Texas for irrigation: Tex. Board Water Engineers dupl. rept., $5 \mathrm{p}$.

General areas are reported where ground water is available in quantities sufficient for irrigation. One limiting factor in irrigation is the lift at which pumping is no longer profitable.

1951b. (and Sundstrom, R. W., and Weaver, D. E.). Public water supplies in western Texas: U. S. Geol. Survey Water-Supply Paper 1106, $168 \mathrm{p} ., 1 \mathrm{pl}$. 
A description of the public water supplies in 81 counties of western Texas, lying generally west of the 100th meridian. Of the 142 public supplies described, 133 use ground water. The use of water for public supply averaged $78 \mathrm{mgd}$, of which $61 \mathrm{mgd}$ was ground water.

For type of data included, see Sundstrom $48 \mathrm{a}$.

1952. Ground-water hydrology: Tex. Board Water Engineers dupl. rept., 9 p.

1953. Coastal Plain near Houston, Texas, in Subsurface facilities of water management and patterns of supply-Type area studies: U. S. Cong., House Comm. Interior and Insular Affairs, Phys. and Econ. Found. Nat. Res. v. 4, chap. 3, p. 51-69, 15 figs.

Pumping could be greater with less water-level decline, if it were less concentrated areally. Unwatering of sands at their outcrops to capture recharge that is now rejected and reduction of natural consumptive use by lowering the water table have not been investigated. Present hydrologic data are inadequate.

1954. Ground-water hydrology: Tex. Univ. Law School Water Law Conf. Proc., p. 5-10.

A major problem in legal control of water resources is the writing of statutes that are in accord with basic hydrologic principles and also flexible enough to be applicable with justice to the wide variety of hydrologic conditions that may be found in any one state.

Brookhart, Joseph W. See also Schlanger, S. O., 55.

1949. The ground-water resources, in The water resources of Anne Arundel County, Maryland: Md. Dept. Geology, Mines, and Water Res. Bull. 5, p. 28-149, pls, 3-7, figs 5-10.

The chief aquifers are sands in the Patuxent and Patapsco formations of Early Cretaceous age, the Raritan and Magothy formations of Late Cretaceous age, and the Aquia formation (greensand) of Eocene age.

Data for the 417-sq-mi area include 600 well records, 6 test-hole logs, 152 well logs, and 102 chemical analyses. Illustrations include a geologic cross section and maps showing the top of the Magothy sand and top of the Aquia formation.

Brown, Delbert W.

1955. Ground-water resources of the Middle Loup division of the lower Platte River basin, Nebraska, with a section on chemical quality of the ground water by F. H. Rainwater; U. S. Geol. Survey Water-Supply Paper 1258, 85 p., 2 pls., 13 figs.

The Middle Loup division of the lower Platte River basin lies in parts of Blaine, Custer, Valley, Sherman, and Howard Counties, Nebraska. Unconsolidated deposits of Quaternary age and the underlying Ogallala formation are the sources of all water yielded by wells in the area. In 1950, all 57 irrigation wells tapped deposits of quaternary age. These wells averaged $115 \mathrm{ft}$ in depth and $875 \mathrm{gpm}$ in yield. The ground water is hard but otherwise satisfactory for domestic use and is exceptionally well suited for irrigation. Little change in chemical quality of the ground water will result from irrigation.

Data for the 650-sq-mi area include 243 well records, records for 241 observation wells, and 21 chemical analyses. Maps show depth to water and water levels. 
Brown, Edwin A. See also Stuart, W. T., 54.

1949. Ground-water resources of Boone County, Indiana: Ind. Div. Water Res. Bull. 4, 152 p., 5 pls., 11 figs.

Sand and gravel deposits within glacial drift are the chief aquifers. Bedrock wells in Devonian limestones and Mississipian limestones and sandstones have small yields.

Data for the 427 -sq-mi area include 720 well records, 103 well logs, and many partial chemical analyses. Maps show water levels and bedrock surface (scale about 1:25,000).

1951. (and Stuart, W. T.). Ground-water resources of the glacial deposits in the Bessemer area, Gogebic County, Michigan, 1950: Mich. Geol Survey Div. Progress Rept. 14, 68 p., 8 figs.

Seven areas near Bessemer are favorable for development of ground-water supplies.

Data for the 120 -sq-mi area include 215 well records, 69 well $\operatorname{logs}$, and 1 comprehensive and 17 partial chemical analyses. Results are given for an aquifer test of outwash sand and gravel at Bessemer. A map shows surficial geology (scale about 1:50,000).

Brown, Eugene. See Cooper, H. H., Jr., 53.

Brown, Glen F. See also Bramkamp, Richard, 48.

1947. Geology and artesian water of the alluvial plain in northwestern Mississippi: Miss. Geol. Survey Bull. 65, 424 p., 13 pls., 38 figs.

Describes the geology and water-bearing properties of the 6 chief artesian aquifers in the Eocene in all or part of 19 counties; also, briefly, ground water in the alluvium. States that artesian pressures over the years have shown marked lowering, and the installation of many wells with multiple screens or multiple-slotted pipe has caused the originally separate pressure systems to become merged in places.

Data for the 6,600-sq-mi area include 1,300 well records, 226 well logs, physical properties of sands, and 65 comprehensive and 90 partial chemical analyses. Maps of water levels in 1938-39 are shown for 4 of the aquifers and a tabulation of declines is given for the 6 aquifers covering periods of one to 39 years. Other illustrations include geologic cross sections and structure maps (scale 1:500,000) showing top of Porters Creek clay, base of Meridian sand, and base of Kosciusko sand.

Brown, Philip M. See LeGrand, H. E., 55c.

Brown, Richmond F.

1950. Ground water in the vicinity of Brush, Colorado: Colo. Water Conserv. Board, Ground-Water Ser., Circ. 2, 27 p., 2 pls.

Abundant ground water is available in the alluvium of South Platte and Big Beaver Valleys. A dependable supply of relatively soft water also can be developed in the sand-dune area of South Platte Valley. In one well iron content dropped with pumping from 7.2 to $0.0 \mathrm{ppm}$.

Data for the 70-sq-mi area include 85 well records, 12 test-hole logs, 21 well logs, and 18 chemical analyses. Illustrations include a fence diagram and a map showing water levels and areal geology (scale about 1:96,000).

1954. Public and industrial water supplies of the Mississippian Plateau region Kentucky: U. S. Geol. Survey Circ. 341, 38 p., 2 pls., 3 figs.

About 33 million gallons of water is pumped each day for public and indus- 
trial supplies in the Mississippian Plateau region. Of this amount, about $25 \mathrm{mgd}$ is pumped from ground-water sources and $8 \mathrm{mgd}$ from surface water. About $12 \mathrm{mgd}$ is used for public supplies and $21 \mathrm{mgd}$ for industrial purposes.

Two maps show graphically the amount of water pumped and the chemical character of the water in the 11,882-sq-mi area. Tables contain data on 68 water supplies and 44 chemical analyses. A generalized section shows the geologic formations present in the area and their water-bearing characteristics.

Brown, Russel H. See ulso Parker, G. G., 55c; Theis, C. V., 51.

1946. (and Ferris, J. G.). Progress report on ground-water resources of the southwestern part of Broome County, New York: N. Y. Water Power and Control Comm. Bull. GW-15, 48 p., 3 pls., 11 figs.

The area includes the "Triple Cities" of Binghamton, Johnson City, and Endicott.

Data for the 200-sq-mi area include 58 well records, 30 logs of borings, 33 chemical analyses, pumpage figures for an 8-year period, results for an aquifer test of sand and gravel at Fenton, and rough estimates of water entering and leaving the area.

1953. Selected procedures for analyzing aquifer-test data: Am. Water Works Assoc. Jour., v. 45, no. 8, p. 844-866, 19 figs.

Demonstrates selected applications of the Theis nonequilibrium formula, as used to determine the hydrologic characteristics of aquifers. These include computation of coefficients of transmissibility and storage and indentification of aquifer boundaries, all on basis of drawdown and recovery data collected at observation wells near a pumped well.

Brown, Stuart C. See Babcock, H. M., 47a, 47b; Halpenny, L. C., 49.

Buford, Thomas B. See Jones, P. H., 51.

Burnham, W. L.

1954. Data on water wells in Borrego, Ocotillo, San Felipe, and Vallecito Valley areas, eastern San Diego County, California: U. S. Geol. Survey dupl. rept., 60 p., 1 pl.

The 250-sq-mi area covers four desert valleys. Data include 174 well records, 46 well logs, 53 chemical analyses, and a geologic reconnaissance map (scale 1:125,000).

1955. Data on water wells in Coyote, Cronise, Soda, and Silver Lake valleys, San Bernardino County, California: U. S. Geol. Survey dupl. rept., 48 p., 1 pl.

The 600-sq-mi area covers four desert basins in the central part of the county. Data include 86 well records, 19 well logs, 37 chemical analyses, and a geologic reconnaissance map (scale $1: 125,000$ ).

Burt, Edward M. See Ferris, J. G., 54.

Burtis, Verle M. See Lohman, S. W., 53c, 53d.

Burton, Lee C. See Barclay, J. E., 53.

Butler, R. Glenn. See Thomas, H. E., $52 \mathrm{e}$.

Byers, A. C.

1946. (and Wenzel, L. K., Laird, W. M., and Dennis, P. E.). Ground water in the Fargo-Moorhead area, North Dakota and Minnesota: U. S. Geol. Survey dupl. rept., 72 p., 1 pl., 4 figs. 
Data for the 375-sq-mi area include 13 test-hole logs, 25 well logs, 1 geologic cross section, pumpage figures, 5 comprehensive and 6 partial chemical analyses, and physical properties of sediment samples.

For a more recent report on this area, see Dennis 49a.

\section{Byrne, Frank Edward}

1948. (and McLaughlin, T. G.). Geology and ground-water resources of Seward County, Kansas: Kans. Geol. Survey Bull. 60, 140 p., 12 pls., 10 figs.

The chief aquifers are the Rexroad, Laverne, and Meade formations throughout the county, and alluvium in the Cimarron Valley. Depth to water ranges from less than $10 \mathrm{ft}$ in parts of Cimarron Valley to more than $200 \mathrm{ft}$ in parts of the upland.

Basic data for the 643-sq-mi county include 162 well records, 23 test-hole logs, 12 well logs, 7 measured geologic sections, and 20 chemical analyses. Illustrations include a water-level map, a depth-to-water map, a geologic fence diagram, and a geologic map (scale 1:125,000).

Callahan, Joseph T. See also Harshbarger, J. W., 53.

1955. (and Cushman, R. L.). Geology and ground-water supplies of the Fort Wingate Indian School area, McKinley County, New Mexico: U. S. Geol. Survey Circ. 360, 12 p., 3 figs.

The San Andres formation contains water under artesian conditions, and wells flow at the land surface. Three water-bearing sandstones are present in the Chinle formation, but they are believed unlikely to yield large amounts of water. Water from the San Andres formation is very hard and contains several hundred parts per million of sulfate.

Data for the 80-sq-mi area include a map of recharge and discharge areas of the San Andres formation, a measured geologic section, a geologic cross section, well- and spring-discharge measurements, and 7 chemical analyses.

Cardwell, W. D. E.

1953. Irrigation-well development in the Kansas River basin of eastern Colorado: U. S. Geol. Survey Circ. 295, 72 p., 3 pls., 5 figs.

The principal source of ground water in the area is the Ogallala formation; less important sources are alluvium and dune sand. Many more irrigation wells can be drilled in some parts of the area without exceeding the perennial yield of the aquifer.

Data for the 9,000-sq-mi area include 178 well records, 336 well logs, and water-level data. Maps show depth to water, water levels, and the erosion surface on the Pierre shale. A geologic fence diagram is included.

Carlston, Charles W.

1955. (and Graeff, G. D., Jr.). Ground-water resources of the Ohio River Valley in West Virginia, in Geology and economics resources of the Ohio River Valley in West Virginia: W. Va. Geol. Survey, v. 22, pt. 3, 131 p., 2 pls., 38 figs.

In the Ohio Valley section of West Virginia, public supplies draw more than $9 \mathrm{mgd}$ of ground water and industry uses $41 \mathrm{mgd}$. The character, thickness, distribution, and hydraulic characteristics of the alluvium are described. Information is given on water-level fluctuations, temperature of the water, and chemical character of the ground water in relation to that of the Ohio River. 
Data include 634 well records, 51 well logs, and 130 chemical analyses, and results for certain aquifer tests of Ohio Valley alluvium.

Carter, R. W.

1951. (and Herrick, S. M.). Water resources of the Atlanta metropolitan area: U. S. Geol. Survey Circ. 148, 19 p., 2 pls., 14 figs.

The area within a 2-mile radius of downtown Atlanta, Georgia, has sufficient water of generally satisfactory chemical quality to satisfy present domestic and industrial requirements except during periods of severe drought. When Buford Dam is completed it is expected that there will be enough water in the Chattahoochee River to supply the growing city of Atlanta and almost any type of industry that wishes to locate in the area. A map shows the range in yield of wells in various rock formations. Information on temperature and chemical quality of ground water is included, and the proper spacing of wells is explained. The public water-supply systems in the area are briefly described.

\section{Cederstrom, D. John}

1946a. Chemical character of ground water in the Coastal Plain of Virginia: Va. Geol. Survey Bull. 68, 62, p., 10 figs.

Gain in bicarbonate as ground water moves eastward is accounted for by chemical or biochemical breakdown of sulfate, with liberation of carbon dioxide which subsequently reacts with carbonate minerals to form bicarbonate. High chloride is considered to be due to incomplete flushing of the sea water with which the sediments were once saturated. The Yorktown formation of Miocene age yields moderately hard or hard calcium bicarbonate water, whereas water from the basal Miocene Calvert and the Eocene Nanjemoy formations is soft to moderately hard and is more similar to water from older deposits.

Data include 145 chemical analyses, a geologic cross section, and maps showing distribution of the major types of artesian water in the Coastal Plain in Virginia and distribution of hardness and fluoride in artesian water.

1946b. Genesis of ground waters in the Coastal Plain of Virginia: Econ. Geology, v. 41, no. 3, p. 218-245, 5 figs.

South of James River, Lower Cretaceous sands are the chief aquifers, whereas north of James River, Eocene strata are penetrated by most deep wells. Along the Fall Zone, water from deep wells is soft and has a low total mineralization. Eastward the water gains in mineral content and becomes a hard calcium bicarbonate water. As it migrates still farther eastward it is softened by base exchange and becomes a soft sodium bicarbonate water. In the vicinity of Chesapeake Bay the water is somewhat brackish and in places contains more than 1,000 ppm of chloride.

Data include 37 chemical analyses and maps showing distribution of the major types of artesian water and distribution of hardness and fluoride in artesian water.

1947a. Geology and water resources of southern Okinawa: Am. Assoc. Petroleum Geologists Bull., v. 31, no. 10, p. 1752-1783, 13 figs.

Deals particularly with the structural geology and water resources of the southern third of Okinawa. Large streams, some of which must be dammed if water is to be available during low-flow periods, and several very large springs are major sources of water. Wells in the Ryukyu limestone are 
practicable in relatively few places and will have rather small yields. Small sand deposits and alluvium will furnish only meager yields.

Data include a geologic map (scale about 1:180,000).

1947b. Artificial recharge of a brackish water well: Commonwealth, v. 14, no 12, p. $31,71-73,4$ figs.

Reviews a test near Williamsburg, Virginia, in which low-chloride water was pumped into a well that had yielded water containing several hundred parts per million of chloride. About 50 per cent of the recharged water was essentially unchanged chemically when pumped out.

1947c. Review of "Geology and ground-water resources of the Island of Hawaii," by H. T. Stearns and G. A. MacDonald: Econ. Geology, v. 42, no. 5, p. 498-500.

1947d. The Arlington gasoline-contamination problem: U. S. Geol. Survey dupl. rept., 5 p., 1 fig.

Ground water in Arlington, Virginia, was contaminated by seepage of gasoline from underground tanks. Test drilling outlined the area of contamination and gave indications as to source and possible spread of the gasoline-bearing water.

1950. Geology and ground-water resources of St. Croix, Virgin Islands: U. S. Geol. Survey Water-Supply Paper 1067, 117 p., 6 pls., 11 figs.

This report discusses the geology of St. Croix, existing water supplies, and a test-drilling project carried out in 1938-39, and describes briefly the National Park Services test-drilling project of 1940-41. Most water used on St. Croix is obtained from cisterns and wells, but during periodic droughts this supply dwindles. Test drilling showed that, in some well-defined alluvial valleys, yields as large as several tens of gallons per minute can be obtained from properly constructed wells less than 100 feet deep. The Tertiary Kingshill marl yields excellent water in places, but elsewhere supplies are very meager or salty, or both. The Cretaceous Mount Eagle volcanics generally yield only small supplies, but a diorite intrusive into the Mount Eagle rocks appears to have better ground-water possibilities. In many places, therefore, dependable wells for domestic supplies could be constructed, but larger supplies are available in very few places. It seems unlikely that water for full-scale irrigation can ever be developed on the island.

Data for the 84-sq-mi island include 165 well records, 14 well logs, 29 chemical analyses, lists of fossils, and a geologic map (scale 1:40,000).

1952. Summary of ground-water development in Alaska, 1950: U. S. Geol. Survey Circ. 169, 37 p., 1 pl.

Development of ground water in Alaska is in an early stage. Substantial developments exist only in the vicinities of Anchorage, Palmer, and Fairbanks. Elsewhere few wells are present and the possibilities are largely unknown. The most prolific aquifers are sandy valley fill and glacial outwash, particularly in the major valleys such as those of the Yukon and Tanana Rivers. Judging from the records of existing wells and from geologic similarity to better known areas elsewhere, supplies of many million gallons per day could be developed in many places. The water ranges in quality from good to poor, and high content of iron and organic matter is a problem in many areas. Little is yet known of the occurrence of water in bedrock. Permafrost is a factor to be considered in location of ground-water supplies and construction of wells in much of the interior. 
The report contains reconnaissance descriptions of the ground-water conditions and developments in about 70 communities south of the Brooks Range, which were visited by airplane beginning in 1947.

1953. (and Johnston, P. M., and Subitzky, Seymour). Occurrence and development of ground water in permafrost regions: U. S. Geol. Survey Circ. 275, 30 p., 11 figs.

This report summarizes the information available on the location and development of ground-water supplies in regions of perennially frozen ground. The occurrence of ground water in large areas of the Arctic and subarctic differs somewhat from its occurrence in more temperate climates, because of the presence of perennially frozen, impermeable ground underlying or interbedded with unfrozen deposits of various degrees of permeability. The problems of drilling wells in areas of permafrost are caused and aggravated by the prevailing low temperatures, both at the surface and in the subsurface. Although cable-tool or percussion-type drilling equipment is best adapted to well drilling in the Artctic, rotary equipment of different types also has been used successfully. With either type, modifications are necessary in equipment and techniques. During the drilling and after completion of the well, special precautions must be taken to prevent freezing. It is concluded that ground water is present in most permafrost areas and its recovery is practicable where the thickness of the permafrost is not too great.

The southern border of permafrost in North America is shown on a map and a selected bibliography is included.

Clark, William E. See Heath, R. C., 51.

Coates, Donald R.

1954. Memorandum on ground-water investigations in the Sells area, Papago Indian Reservation, Pima County, Arizona: U. S. Geol. Survey dupl. rept., 6 p., 1 pl.

The aquifers are sand and gravel beds in alluvium. Data for the 6-sq-mi area include 32 well records and a water-level map.

1955. (and Cushman, R. L.). Geology and ground-water resources of the Douglas basin, Arizona, with a section on quality of water by $\mathbf{J}$. $\mathbf{L}$. Hatchett: U. S. Geol. Survey Water-Supply Paper 1354, 56 p., 5 pls., 5 figs.

Douglas basin lies in Cochise County and is part of a large intermontane valley known as Sulphur Spring Valley. Ground water occurs largely in the saturated zone of the valley-fill sediments, especially in thin lenses and strata of sand and gravel which are interbedded with large thicknesses of silt and clay. Gypsum beds and extensive caliche deposits occur both on the surface and within the valley fill at various depths. Although the valley-fill sediments are as much as $2,800 \mathrm{ft}$ thick, the uppermost $300 \mathrm{ft}$ are the most permeable. In 1951, total ground-water discharge was about 50,000 acre-ft.

Data for the 1,200-sq-mi basin include 64 well and 11 spring records, 16 well logs, and 40 chemical analyses. Maps (scale 1:250,000) show water levels, depth to water, water-level change (1947-52), dissolved-solids content of the water, and areal geology.

Colby, Bruce Ronald. See Gatewood, J. S., 50.

Conover, Clyde S.

1942a (1953). (and Akin, P. D.). Progress report on the ground-water 
supply of Mimbres Valley, New Mexico, 1938-42: N. Mex. State Engineer 14th and 15th Bienn. Repts., p. 237-282, 12 figs.

In Membres Valley, Luna County, New Mexico, significant amounts of water are recharged to the aquifer only during years of exceptional rainfall such as 1941. Such years occur infrequently, and the effects of recharge are likely to be offset by extremely dry years in the long run. Most of the water being pumped is derived from storage, and water levels probably will continue downward.

Data include precipitation, monthly and annual discharge of Mimbres River, power use and pumpage of ground water, two aquifer tests, specific capacities of wells, and studies of water-level fluctuation. Illustrations show irrigated areas, changes in water levels, and depth to water.

1942b (1953). (and Akin, P. D.). Progress report on the ground-water supply of northern Lea County, New Mexico: N. Mex. State Engineer 14th and 15th Bienn. Repts., p. 285-309, 3 figs.

Because the ground water is being pumped from storage, water levels must decline more or less proportionately with pumping. Pumpage was 1,800 acre-ft in 1938.

Data include 2 well $\operatorname{logs}$ and maps of water-level change.

1942c (1953.) (and Akin, P. D.). Progress report on the ground-water supply of Portales Valley, New Mexico: N. Mex. State Engineer 14th and 15th Bienn. Repts., p. 313-346, 9 figs.

Water levels declined gradually as much as $10 \mathrm{ft}$ from 1932 to 1941 , mainly because of pumping, but rose to unprecedented levels after the heavy precipitation in 1941. Significant recharge occurs only during such infrequent periods of excess rainfall.

Data include precipitation and evaporation records, irrigation pumpage $(19,500$ acre-ft in 1939), and depth-to-water measurements. Illustrations include 6 maps of water-level change.

1951. Ground-water resources in New Mexico: N. Mex. Prof. Engineer, v. 3, no. 7, p. 9-12, figs. 1-3, July; v. 3, no. 8, p. 6-9, figs. 4-5, Aug.-Sept.

In areas of New Mexico remote from through-flowing surface streams, much or all of the ground-water reserve is being progressively diminished, or mined. In areas in or near stream valleys, the use of ground water will eventually reduce the flow of the surface streams. In the first-described areas, ground-water development should be limited in order to allow as much water as possible to drain toward irrigable areas, or other areas of water need. In the areas along streams, the ground-water body should be regarded as forming a reservoir and treated accordingly.

Maps show water-level decline from 1940 to 1950 in Mimbres and Portales Valleys and the Roswell shallow ground-water basin. Diagrams show theoretical effects of pumping.

1954. Ground-water conditions in the Rincon and Mesilla Valleys and adjacent areas in New Mexico: U. S. Geol. Survey Water-Supply Paper 1230, 200 p., 9 pls., 15 figs.

Rincon and Mesilla Valleys, the two southernmost expanded flood plains of the Rio Grande in New Mexico, are parts of the Rio Grande project of the U. S. Bureau of Reclamation. Droughts that resulted in deficient water storage in Elephant Butte and Caballo reservoirs gave impetus to the drilling of wells for water for irrigation. Surface and ground water in the valleys 
are interrelated in such a way that water pumped from ground-water storage is in effect "borrowed" from future supplies of surface water. At the time of the investigation (1946-48) only about 70 irrigation wells had been constructed or were under construction, but enough wells could be developed to furnish most of the water needed to irrigate about 100,000 acres in the valleys.

Data for the 500-sq-mi area include 255 well records, 53 well logs, 43 chemical analyses, periodic water-level measurements, water-level maps, a measured section of the Santa Fe formation, and results for aquifer tests of alluvium in the two valleys.

1955. (and Herrick, E. H., Hood, J. W., and Weir, J. E., Jr.). The occurrence of ground water in south-central New Mexico: N. Mex. Geol. Soc. Guidebook, 6th Field Conf., p. 108-120, 1 fig.

Conditions in four areas are described: The Truth or Consequences (Hot Springs) area, the Rio Grande valley south of Truth or Consequences, the Jornada del Muerto, and the Tularosa basin. The most dependable supplies of usable ground water in south-central New Mexico are found in the valley fill in the Rio Grande valley. Permeable river alluvium in the valley yields large quantities of water to irrigation wells. Elsewhere, in the La MesaJornada del Muerto and Tularosa intermontane basins, Tertiary and younger fill is less permeable and usually contains impotable water except near the edge of mountain masses. Consolidated rocks in this area do not supply appreciable quantities of potable water except the Yeso formation of Permian age, which supplies municipal and irrigation water from springs in the western Sacramento Mountains.

A map (scale about 1:1,200,000) shows water levels in intermontane basins in south-central New Mexico. Data for the average discharge and quality of thermal water in the Truth or Consequences area are given.

Cooper, Hilton H., Jr. See also Stringfield, V. T., 51a, 51b, 51c; Unklesbay, A. G., 46.

1946. (and Jacob, C. E.). A generalized graphical method for evaluating formation constants and summarizing well-field history: Am. Geophys. Union Trans., v. 27, no. 4, p. 526-534.

An approximate solution of the Theis equation can be obtained by a straight-line plot on semilog paper. Type curves are not required. The method is developed for tests involving a single discharging well operating at a steady rate, and is then generalized to apply to tests involving one or more wells discharging intermittently or at changing rates.

1950. (and Stringfield, V. T.). Ground water in Florida: Fla. Geol. Survey Inf. Circ. 3, 6 p., 4 figs.

Ground water in Florida is discussed as to occurrence, source and movement, consumption, and problems of development and conservation. Maps of Florida show areas in which water having a chloride content of more than $100 \mathrm{ppm}$ occurs at moderate depth, top of Ocala limestone, water levels in principal artesian aquifer, and areas of artesian flow.

1953. (and Kenner, W. E., and Brown, Eugene). Ground water in central and northern Florida, in Subsurface facilities of water management and patterns of supply-Type area studies: U. S. Cong., House Comm. Interior and Insular Affairs, Phys. and Econ. Found. Nat. Res., v. 4, chap. 9, p. 147-161, 23 figs; reprinted as Fla. Geol. Survey Rept. Inv. 10,37 p., 23 figs. 
Precipitation is aboundant, hence water is not in short supply. The area is unusual in that land surface is drained largely by movement of water underground. Water on the way to the ocean alternates between surface and ground water. Techniques are not yet available to handle studies of many local features of the hydrologic cycle.

Coskery, Oscar J. See also Boggess, D. H., 55.

1956 (1955). (and Boggess, D. H.). Water levels and artesian pressures in Delaware, 1954: Del. Geol. Survey Water-Level Rept. 3, 10 p., 2 figs.

An advance release of the data included in the Delaware section of the annual water-level report (see table 1 and figure 1 ).

Counts, H. B.

1954. (and Engler, Kyle). Changes in water levels in deposits of Quaternary age in eastern Arkansas from 1938 to 1953: Ark. Univ. Agr. Expt. Sta., Rept. Ser. 42, 11 p., 3 figs.

Water levels have declined from 0 to $10 \mathrm{ft}$ in 73 percent of the area, from 10 to $20 \mathrm{ft}$ in 13 percent, and more than $20 \mathrm{ft}$ in 3 percent. A slight rise in water levels is shown in about 11 percent of the area. Illustrations show water levels in 1938 and 1953 and water-level change from 1938 to 1953.

1955. (and Tait, D. B., Klein, Howard, and Billingsley, G. A.). Groundwater resources in a part of southwestern Arkansas: Ark. Geol. and Conserv. Comm. Water Res. Circ. 2, 35 p., 6 pls., 8 figs.

Chief aquifers are Trinity group, Tokio formation, and Nacatoch sand, all of Cretaceous age. Ground water is progressively more mineralized down dip. Ground-water use is $8.5 \mathrm{mgd}$.

Data for the 3,900-sq-mi area include 397 well records, 10 well logs, 328 chemical analyses, and data for aquifer tests of the Nacatoch sand, the Tokio formation, and Quaternary deposits. Illustrations include a geologic cross section; maps of outcrops of Trinity group, outcrops and contours on top of Tokio formation, and outcrops and contours on top of Nacatoch sand; and a geologic map based on a published source.

Cox, E. R. See Hale, W. E., 54.

Criner, James H., Jr. See Onellion, F. E., 55.

Cromack, G. H. See Sundstrom, R. W., $49 \mathrm{~b}$.

Cross, William P. See also Norris, S. E., 52b.

1949. The relation of geology to dry-weather stream flow in Ohio: Am. Geophys. Union Trans., v. 30, no. 4, p. 563-566, 3 figs.

The base flow of several streams in Ohio is shown by flow-duration curves. For comparison of basins in Ohio, the index of ground-water flow is the discharge in cfs per sq mi that is exceeded 90 percent of the time. Streamflow records provide basis for useful inferences to ground-water hydrology, but the converse is not true. A map of Ohio shows indices of base flow taken from duration curves.

1952. (and Schroeder, M. E., and Norris, S. E.). Water resources of the Mahoning River basin, Ohio, with special reference to the Youngstown area: U. S. Geol. Survey Circ. 177, 57 p., 1 pl., 24 figs.

Shortage of water for industrial use, gross pollution, high temperature of river water, and danger of floods present serious problems in the Mahoning 
River valley. The Youngstown area has 11 per cent of the Nation's steelproducing capacity and is the fourth largest steel center in the world. Total water demand including recirculation has been estimated at 1,270 mgd, equivalent to more than twice the average flow of the Mahoning River, the largest source of supply. The report summarizes and documents these facts and other available information that will assist with the development, control, and use of the water resources in this heavily industrialized region. The quantity and quality of water available, present water use, future water requirements, and possibilities for expanding the water supply are discussed with related physiographical features of the basin.

Maps show the distribution and water-bearing characteristics of the glacial deposits and of the consolidated rocks.

Crosthwaite, E. G. See Ferris, J. G., 54.

Cummins, J. W.

1947. (and Sanderson, E. E.). The water resources of Tuscarawas County, Ohio: Ohio Water Res. Board Bull. 6, 52 p., 18 pls.

The chief aquifer is glacial outwash in the main valleys. Sandstones in the bedrock yield enough water for farm and domestic purposes. In the development of any new supply, consideration must be given to the fact that water in the Tuscarawas River is high in chloride, and heavy pumping from wells near this stream may induce infiltration of such water. Also, drilling of fresh-water wells below depths of $350 \mathrm{ft}$ is unwise because of the presence of brine in most formations below this depth.

Data for the 571-sq-mi county include 22 chemical analyses, pumpage figures, 4 geologic cross sections, and an areal geologic map (scale about $1: 150,000)$.

Cushing, Elliott M. See Schneider, Robert, 48.

Cushman, Robert L. See also Callahan, J. T., 55; Coates, D. R., 55; Jones, R. S., 47.

1947. (and Jones, R. S.). Geology and ground-water resources of the San Simon basin, Cochise and Graham Counties, Arizona, with a section on quality of water by J. D. Hem: U. S. Geol. Survey dupl. rept., 27 p., 2 pls., 2 figs.

Between 1915 and 1946, artesian head in the valley fill decreased about $30 \mathrm{ft}$ in the flowing-well area near San Simon.

Data include 24 well records, 6 well logs, 15 chemical analyses, and a geologic map (scale about $1: 290,000$ ). For a more recent report, see Halpenny 52.

1955. (and Halpenny, L. C.). Effect of western drought on the water resources of Safford Valley, Arizona, 1940-1952: Am. Geophys. Union Trans., v. 36, no. 1 , p. 87-94, 4 figs.

The period 1940-41 was much wetter than average, and the period 1942-52 was much drier than average. The immediate effect of the drought was a decline in runoff, an increase in ground-water withdrawals, and a lowering of the water table. When the water table is low, the ground-water contains more dissolved matter and hence is less desirable. Even when the drought ends, the slow rate at which recharge moves from the mountain areas to the irrigated inner valley will cause effects of the drought to persist for some years. 
The drought had two beneficial effects: (1) the river bed when dry provided greater opportunity for recharge than when flow was perennial; and (2) the waste by phreatophytes was reduced.

\section{Cushman, Robert V.}

1950a. The ground-water resources of Rensselaer County, New York: N. Y. Water Power and Control Comm. Bull. GW-21, 56 p., 3 pls., 4 figs.

Stratified drift and related sand and gravel of fluvial origin are the best aquifers in the county. Bedrock yields small supplies of water, generally sufficient only for domestic and farm needs.

Data for the 651-sq-mi area include 350 well and 17 spring records, 22 well $\operatorname{logs}, 65$ chemical analyses, a geologic cross section, and a geologic map adapted from existing sources.

1950b. Bibliography of publications relating to ground water in Connecticut: Conn. Water Comm. and Dept. Health dupl. bibliography, 14 p., index map.

The biblography has an abstract for each of 57 reports issued through June 1, 1950. An index map aids in determining whether a report covering a particular area is available.

1952. Possible ground-water developments in Connecticut: Conn. Soc. Civil Engineers 68th Ann. Rept., p. 90-102, 6 figs.

Portrays the role of the aquifer in water supply and outlines the factors that should be considered in planning the development of a dependable ground-water supply.

1953a. The ground-water resources of Washington County, New York:

N. Y. Water Power and Control Comm. Bull. GW-33, 65 p., 3 pls., 10 figs.

Beds of coarse sand and gravel in outwash and delta deposits are the most productive water-bearing beds in the county. Bedrock is locally a poor source of water but is commonly well jointed, permitting small supplies to be obtained. The average yield of wells in sand and gravel is about 10 times the average of wells in bedrock. Mineralized water is found in wells near normal faults. A resistivity survey was used to delineate buried valleys.

Data for the 837-sq-mi area include more than 500 well and spring records, 29 well $\operatorname{logs}$, 39 chemical analyses, physical properties of sediments, and geologic maps of bedrock and surficial deposits adapted from existing sources.

1953b. (and Allen, W. B., and Pree, H. L., Jr.). Geologic factors affecting the yield of rock wells in southern New England: New England Water Works Assoc. Jour., v. 67, no. 2, p. 77-95, 4 pls., 1 fig.; Reprinted as Sci. Contr. Conn. State Water Comm., R. I. Devel. Council, and Mass. Dep. Public Works.

Rock type, geologic structure, topography, well depth, and type of overburden affect the yield of wells in bedrock. Averages of data for rock wells in southern New England are summarized in five tables.

A map shows the generalized bedrock geology of southern New England (scale about 1:1,600,000).

1955. Statement on ground water in Connecticut: Conn. Devel. Comm. Reference Manual of Indus. Location Factors, v. 5, sec. 7, p. 26-30, $1 \mathrm{pl}$.

A brief discussion of occurrence, availability, and quality of ground water 
in Connecticut. Gives expectable yields of wells in the several aquifers. Map shows promising areas for moderate to large ground-water development.

Dale, 0. C.

1952. Ground-water resources of Starr County, Texas: Tex. Board Water Engineers Bull. 5209, 47 p., 3 figs., 1 pl.

The Goliad sand is the chief aquifer. Alluvium in the Rio Grande Valley also is an important source of water.

Data for the 1,207-sq-mi area include 421 well records, 67 well logs, 2 cross sections showing electric logs, and 132 chemical analyses.

1953. (and Broadhurst, W. L.). Memorandum on ground-water irrigation in Mitchell County, Texas: Tex. Board Water Engineers dupl. rept., 12 p., 1 fig.

Data include 48 well records, 19 well logs, and 21 chemical analyses.

1954. (and George, W. O.). Ground-water resources of Cameron County, Texas: Tex. Board Water Engineers Bull. 5403, 63 p., 1 pl., 4 figs.

The chief aquifer is sand and gravel in the Rio Grande Valley, but only locally does it yield supplies of acceptable quality large enough to support irrigation or large-scale municipal pumping.

Data for the 883 -sq-mi area include 325 well records, 86 well $\operatorname{logs}, 200$ chemical analyses, and facsimiles of electric logs.

Dante, J. H. See also Follett, C. R., 46.

1946. Brisco County, Texas; records of wells, drillers' logs, water analyses, and map showing locations of wells: Tex. Board Water Engineers dupl. rept., 25 p., 1 map.

Data for the 887 -sq-mi county include 180 well records, 13 well logs, and 23 chemical analyses.

1947. Records of wells and springs in northern Pecos County, Texas: Tex. Board Water Engineers dupl. rept., 87 p., 1 pl.

Data include 437 well records, 108 well logs, and 238 chemical analyses.

Davis, Dan A. See Wentworth, C. K., 55.

Davis, George H. See also Poland, J. F., 51.

1952. (and Olmsted, F. H.). Geologic features and ground-water storage capacity of the Sutter-Yuba area, California, appendix B in SutterYuba Counties Investigation: Calif. Water Res. Board Bull. 6, p. 89104, 4 pls.

The estimated ground-water storage capacity in the Sutter-Yuba area between 20 and $200 \mathrm{ft}$ below land surface is $3,900,000$ acre- $\mathrm{ft}$. It is not known how much of this capacity is economically usable.

Data on storage capacity are given by area and type of deposit. Illustrations include 4 geologic cross sections and a map of areal geology (scale about $1: 200,000)$. The geologic events in the Sierra Nevada and on the east side of Sacramento Valley are listed in tabular form.

1954. (and Poland, J. F., and others). Ground-water conditions in the Mendota-Huron area, Fresno and King Counties, California: U. S. Geol. Survey Water-Supply Paper 1360-G, p. 409-587, pls. 28-36, figs. 66-73.

Discusses the development and chemical quality of ground water in this part of the San Joaquin Valley, estimates the recharge to and discharge from 
the ground-water bodies, and concludes that the net annual ground-water overdraft as of 1951 was about 350,000 acre-ft.

Data for the 1,300-sq-mi area include descriptions and chemical analyses for 803 wells, 3 geologic cross sections, a water-level map, representative hydrographs, and geochemical cross sections.

1955. (and Worts, G. F., Jr., and Wilson, H. D., Jr.). Water-level fluctuations in wells, in Earthquakes in Kern County, California, during 1952: Calif. Div. Mines Bull. 171, p. 99-106, 3 figs.

The Arvin-Tehachapi earthquake of July 21, 1952, caused fluctuations to be recorded in several California wells, with amplitudes of flucțuation ranging from $7.34 \mathrm{ft}$ in a well 20 miles northeast of the epicenter to $0.012 \mathrm{ft}$ in a well 180 miles southeast of the epicenter. Many records, especially from wells near the epicenter, show a small residual displacement of the water level above or below the level prior to the earthquake. Although the watersurface movements in wells penetrating partially confined or confined aquifers tend to decrease with distance from the epicenter, these fluctuations appear to be more directly related to the compressibility and elasticiy of the aquifer materials than to the degree of confinement of the aquifer or the distance of the well from the epicenter.

\section{Davis, Leon V.}

1950. Ground water in the Pond Creek basin, Caddo County, Oklahoma: Okla. Geol. Survey Min. Rept. 22, 23 p., 1 pl., 5 figs.

The chief aquifer is the Rush Springs sandstone. The formation consists mainly of very fine grained sandstone which is as much as $335 \mathrm{ft}$ thick. Results of one aquifer test show that $225 \mathrm{gpm}$ is the maximum yield of the well tested.

Data for the 320-sq-mi basin include also 8 well records, a graphic well log, and 12 chemical analyses.

1955. Geology and ground-water resources of Grady and northern Stephens Counties, Oklahoma: Okla. Geol. Survey Bull. 73, 184 p., 2 pls., 14 figs.

Chief aquifers are the Duncan and Rush Springs sandstones, terrace deposits, and alluvium. Other formations yield enough water for farm and domestic use, although in some areas it is highly mineralized.

Data for the 1,236-sq-mi area include 94 well records, 73 chemical analyses, aquifer tests of the Duncan and Rush Springs sandstones and the terrace deposits, and a geologic map (scale 1:63,360).

DeBuchananne, George D. See also Barksdale, H. C., 46.

1950. Ground water in relation to mining in the southeastern States, in Snyder, F. G., ed., Symposium on mineral resources of the southeastern United States: Knoxville, Tenn. Univ., p. 223-227.

Describes usefulness of ground-water studies as applied to mining, particularly in problems of dewatering.

\section{DeCook, Kenneth J.}

1955. (and Doyel, W. W.). Records of wells in Hays County, Texas:

Tex. Board Water Engineers Bull. 5501, 60 p., 1 pl.

Data for the 670 -sq-mi county include 482 well and spring records, 43 well logs, 235 chemical analyses, and periodic measurements of depth to water for. 41 wells. 


\section{de Laguna, Wallace}

1946. (and Brashears, M. L., Jr.). The configuration of the rock floor in western Long Island, New York: N. Y. Water Power and Control Comm. Bull. GW-13, 40 p., 1 map.

Because bedrock in the area is quite dense and impermeable, the bedrock surface represents the maximum depth to which a well can be drilled with expectations of finding water.

The map (scale $1: 125,000$ ) of the bedrock surface is based on records of 250 wells that reached or penetrated bedrock.

1948. Geologic correlation of logs of wells in Kings County, New York:

N. Y. Water Power and Control Comm. Bull. GW-17, 35 p., 3 pls.

Two geologic cross sections are based on the interpretation of about 400 logs of water wells in Brooklyn. Maps show location of wells and formations penetrated.

1949a. Geologic history of Long Island, in Suter, Russell, Mapping of geologic formations and aquifers of Long Island, New York: N. Y.

Water Power and Control Comm. Bull. GW-18, p. 25-46.

Outlines the geologic history of Long Island and attempts to distinguish between well-established and less well-established events. Unfortunately, well-established events are few.

1949b. (and Perlmutter, N. M.). Tables of geologic correlations of well $\log _{\mathrm{s}}$ in Long Island, in Mapping of geologic formations and aquifers of Long Island, New York: N. Y. Water Power and Control Comm. Bull. GW-18, p. 47-138.

Data given include total depth, elevation with respect to sea level of formational contacts, the reliability of the correlation, the screen setting, and the aquifer developed.

1953. Modified Norris electric tape: U. S. Geol. Survey dupl. rept., 5 p., 4 figs.

In order to measure water levels in wells having water that contains less than $50 \mathrm{ppm}$ of dissolved solids, a 0-80 micrometer was used. Long, narrow strips of sheet lead were fastened just above the magnesium tip at the end of the tape. These lead weights were held on by friction tape and painted with plastic or glyptol. Such a tape can be used in piezometers and wells where space limitations prevent use of ordinary tape weights.

Dennis, P. Eldon. See also Arnow, Saul, 53a, 53b; Byers, A. C., 46.

1946. (and Maxey, G. B., and Thomas, H. E.). Ground water in Pavant Valley, Millard County, Utah: Utah State Engineer Tech. Pub. 3, 96 p., 1 pl., 11 figs.

The chief aquifers are beds of unconsolidated sand and gravel in the valley fill. Much ground water may leak from the valley fill through basalt cones and lava fields along the western margin. At most places a well in the valley fill may intersect several artesian aquifers confined by : impermeable lake beds.

Data for the 300-sq-mi valley include 296 well records, 1 well $\log , 102$ chemical analyses, well-discharge measurements, and an areal geologic map (scale 1:62,560).

1947a. Ground water near Buxton, Traill County, North Dakota: U. S. Geol. Survey N. Dak. Ground-Water Studies 5, 29 p., 3 figs. 
Ridges of fine sand and gravel yield water to wells 7 to $120 \mathrm{ft}$ deep. Artesian water too highly mineralized for domestic use is obtained from fine sand in wells 160 to $450 \mathrm{ft}$ deep.

Data for the 72 -sq-mi area include 37 well records, 7 test-hole logs, and 19 chemical analyses.

1947b. Ground water in the Aneta area, Nelson County, North Dakota:

U. S. Geol. Survey N. Dak. Ground-Water Studies 7, 23 p., 2 figs.

A perennial supply of 30,000 to $50,000 \mathrm{gpd}$ is estimated to be available from sands and gravels deposited as glacial outwash in a channel.

Data for the 24-sq-mi area include 26 well records, 7 test-hole $\operatorname{logs}, 10$ chemical analyses, and a geologic sketch map (scale about 1:96,000).

1947c. Ground water in the Sharon area, Steele County, North Dakota:

U. S. Geol. Survey N. Dak. Ground-Water Studies 8, 29 p., 3 figs.

Buried gravel underlying the till of an end moraine appears to be a possible aquifer in the area.

Data for the 15-sq-mi area include 31 well records, 18 test-hole logs, 8 chemical analyses, and a geologic sketch map (scale about 1:100,000).

1948a. Ground water in the Wimbledon area, Barnes and Stutsman Counties, North Dakota: U. S. Geol. Survey N. Dak. Ground-Water Studies 10, 38 p., 2 figs.

Four previously unknown glacial-drift aquifers are described, the largest capable of supplying about $100,000 \mathrm{gpd}$.

Data for the 15-sq-mi area include 62 well records, 13 test-hole logs, 27 chemical analyses, a list of Foraminifera found in a core of the Niobrara shale, a geologic section, and a geologic map (scale about 1:43,000).

1948b. Ground water in the Hope area, Steele County, North Dakota: U. S. Geol. Survey N. Dak. Ground-Water Studies 9, 30 p., 2 figs.

The only aquifer is a deposit of sand and gravel 4 to $26 \mathrm{ft}$ thick. It was deposited as glacial outwash and later covered by a readvance of the ice which, on melting, left a cover of till of variable thickness.

Data for the 7-sq-mi area include 51 well records, 10 test-hole logs, and 16 chemical analyses.

1949a. (and Akin, P. D., and Jones, Suzanne L.). Ground water in the Wyndmere area, Richland County, North Dakota: U. S. Geol. Survey N. Dak. Ground-Water Studies 13, 59 p., 7 figs.

Supplies on the order of 30,000 to $70,000 \mathrm{gpd}$ possibly can be developed from sands of the Sheyenne delta of Lake Agassiz. A part of the deltaic materials at most localities and the entire thickness of the Lake Agassiz deposits in some localities are too fine grained to serve as aquifers.

Data for the 138-sq-mi area include 207 well records, 37 test-hole logs, 1 well $\log , 11$ chemical analyses, 6 geologic cross sections, and a geologic map (scale about 1:80,000).

1949b. (and Akin, P. D., and Worth, G. F., Jr.). Geology and groundwater resources of parts of Cass and Clay Counties, North Dakota, and Minnesota: U. S. Geol Survey N. Dak. Ground-Water Studies 11; Minn. Ground-Water Studies 1, 177 p., 8 figs.

The chief aquifers in this, the so-called Fargo-Moorhead area, are narrow, elongate glaciofluvial bodies of sand and gravel lying beneath the Lake Agassiz silt and in places underlain by several hundred feet of older lake 
clay and drift deposits. Differential compaction has produced low ridges in the lake plain above some of the aquifers, thus revealing their presence. Current withdrawal of ground water in the area is about $2 \frac{1 / 2}{\mathrm{mgd}}$. As the recharge is only about $1 \mathrm{mgd}$, about $1 \frac{1}{2} \mathrm{mgd}$ is being withdrawn from storage, causing water levels to decline. The large amount of water that remains in storage is sufficient to support the present withdrawal for many years, and by restricting future withdrawals to the most favorable parts of the area, a large part of the stored water can be recovered without excessive lowering of the water levels.

Data for the 360-sq-mi area include 546 well records, 31 test-hole logs, 46 well logs, 17 chemical analyses, 6 geologic cross sections, pumpage figures, and aquifer-test results for glacial drift.

1950a. (and Akin, P. D.). Ground water in the Portland area, Traill County, North Dakota: U. S. Geol. Survey N. Dak. Ground-Water Studies 15, 50 p., 6 figs.

A supply of ground water adequate in both quality and quantity for municipal or other large-scale uses is unlikely to be found in or immediately adjacent to the town of Portland. However, considerable quantities of highly mineralized water are available at depths of about 450 feet from the Dakota sandstone and lesser quantities of good water can be obtained from wells and springs in sands of the Elk Valley delta southwest of the town of Portland.

Data for the 120-sq-mi area include 179 well records, 39 test-hole logs, 15 chemical analyses, and results of an aquifer test on an artesian Cretaceous(?) sand at Portland.

1950b. (and Akin, P. D., and Jones, Suzanne L.). Ground water in the Kindred area, Cass and Richland Counties, North Dakota: U. S.

Geol. Survey N. Dak. Ground-Water Studies 14, 75 p., 13 figs.

Two sand beds deposited in glacial Lake Agassiz, one on the lake bottom and the other in a delta, are the most important aquifers. Town wells, located on the basis of this study, draw from the basal sand of the Lake Agassiz silt and presently supply municipal needs. Estimates suggest that storage is sufficient to supply the town through several dry seasons in which recharge is reduced or negligible.

Data for the 144-sq-mi area include 328 well records, 23 test-hole logs, 19 well logs, 20 chemical analyses, an aquifer test of Lake Agassiz deposits at Kindred, 7 geologic cross sections, and a geologic map (scale about 1:80,000).

1954. Geology and ground-water hydrology of the Lake Hefner area (Okla.), in Water-loss investigations-Lake Hefner studies, technical report: U. S. Geol. Survey Prof. Paper 269, p 10-16, figs 8-9.

The Hennessey shale underlying Lake Hefner is of such low permeability that seepage loss from the reservoir is estimated at only 0.2 acre-ft per day.

Deutsch, Morris. See Stewart, J. W., 54.

\section{Dingman, Robert J.}

1954a. (and Gordon, E. D.). Geology and ground-water resources of the Fort Berthold Indian Reservation, North Dakota, with a section on chemical quality of ground water by H. A. Swenson: U. S. Geol. Survey Water-Supply Paper 1259, 115 p., 2 pls., 15 figs.

In upland areas, the chief aquifers are lignite beds and the associated fine- to medium-grained sandstone beds of the Fort Union formation. The 
filling of Garrison Reservoir will cause a rise of water levels in aquifers now discharging below the operating level of the reservoir. All the permeable strata below this level will become saturated and ground-water bodies that are now separated will become hydraulically united.

Data for the 1,000-sq-mi area include 335 well records, 475 spring records, 113 test-hole logs, 39 chemical analyses, and measured geologic sections. Illustrations include a geologic cross section and maps showing water levels (scale about 1:125,000) and areal geology (scale 1:96,000).

1954b. (and Meyer, Gerald). The ground-water resources, in The water resources of Howard and Montgomery Counties: Md. Dept. Geology, Mines, and Water Res. Bull. 14, p. 1-139, pls. 1-5, figs 1-15.

Because the most extensive aquifers are crystalline rocks of early Paleozoic and Precambrian age, only moderately large perennial ground-water supplies can be obtained at best.

Data for the 745-sq-mi area include 684 well records, 180 well logs, and a generalized geologic map (scale about 1:125,000) based on existing sources. Studies show the relations between well depth, topographic location, geology, and well yields.

Dow, V. T. See Gordon, E. D., 53.

Doyel, William W. See also DeCook, K. J., 55; George, W. O., 52c; Winslow, A. G., 54a, 54b, 54c.

1954. (and Winslow, A. G., and Naftel, W. L.). Pumpage of ground water and decline of artesian pressure in the Houston district, Texas, during 1951 and 1952: Tex. Board Water Engineers Bull, 5401, 28 p., 21 figs.

Withdrawals of ground water in the Houston district averaged $308 \mathrm{mgd}$ in 1952. The largest recorded decline of artesian pressure between spring measurements of 1951 and 1953 was $49 \mathrm{ft}$ in the Pasadena area.

Maps show water levels in the district as of January 1941, March 1951, and March 1953.

Drescher, William J. See also Foley, F. C., 47, 53; Harder, A. H., 54.

1953a. Ground-water conditions in artesian aquifers in Brown County, Wisconsin: U. S. Geol. Survey Water-Supply Paper 1190, 49 p., 7 pls., 13 figs.

The chief aquifers are thick sandstone units of Cambrian and Ordovician age. Ground water is the source of all public and most private and industrial supplies in the county. The report includes data on water levels and the use of ground water from 1886 through 1949. An appendix gives additional data on water levels and pumpage for 1950-51. Around Green Bay, water levels have declined about $400 \mathrm{ft}$ owing to concentrated pumping. Data from aquifer tests are used to compute probable future declines of water level. The water from the sandstones is a hard calcium magnesium bicarbonate water.

Basic data for the 525-sq-mi area include 97 well records and 38 partial chemical analyses. Interpretive data include water-level maps for 1905 , March 1949, and September 1949; 3 cross sections; and maps showing distribution of chloride, fluoride, sulfate, and dissolved solids in the artesian water in the Green Bay area. 
1953b. (and Dreher, F. C., and Brown, P. N.). Water resources of the Milwaukee area, Wisconsin: U. S. Geol. Survey Circ. 247, 42 p., 25 figs.

In 1950 about $482 \mathrm{mgd}$ of surface and ground water was used in the area but much larger quantities of water can be developed. The public watersupply systems are described and the source and quality of the water served is given. The water-bearing properties of the important geologic formations are described. A map shows the bedrock surface. Water levels in wells in the Pleistocene glacial drift, Niagara dolomite, and sandstone aquifers of Cambrian and Ordovician age are given for the period 1946-50. Tables and graphs show the chemical quality and temperature of water from ground and surface sources. Laws affecting the use of water in the area are described briefly and the water-resources potential of the area is evaluated.

1955. Some effects of precipitation on ground water in Wisconsin: Wis. Geol. Survey Inf. Circ. 1, 17 p., 5 figs.

Reviews the effects of short-term, seasonal, and long-range variations in precipitation on confined and unconfined aquifers.

Durum, Walton H. See also Prior, C. H., 54; Searcy, J. K., 52.

For sections describing chemical quality of water in-

Box Butte County, Nebraska, see Nace, 63.

Dutch Flats area, Wyoming, see Babcock, 51.

Glendo-Wendover area, Wyoming, see Rapp, $53 b$.

Horse Creek-Bear Creek area, Wyoming, see Babcock, 52a.

La Prele area, Wyoming, see Rapp, 53c.

Missouri River Valley, northeastern Montana, see Swenson, F. A., 55.

Pass Creek Flats area, Wyoming, see Visher, 52.

Pumpkin Creek area, Nebraska, see Babcock, 52b.

(and Robert A. Krieger) Soil and moisture demonstration area, near Torrington, Wyoming, see Visher, 53.

1953. Relationship of the mineral constituents in solution to stream flow,

Saline River near Russell, Kansas: Am. Geophys. Union Trans., v. 34, no. 3 , p. $435-442,6$ figs.

Runoff from ground-water sources contributed 35 percent of the total runoff and 76 percent of the annual dissolved-solids discharge. Ground water discharging to the Saline River and its tributaries carries strong concentrations of dissolved minerals leached from saliferous and gypsiferous materials. Sodium, chloride, and sulfate are the most prominent constituents. Chloride concentrations of more than $1,900 \mathrm{ppm}$ were identified with low flow, and the chloride content was shown to be related hyperbolically to streamflow.

Dwyer, B. C. See Sunstrom, R. W., 49a.

Eakin, Thomas E. See also Loeltz, O. J., 53; Maxey, G. B., 49, 50.

1949 (1951). (and Maxey, G. B., and Robinson, T. W.). Ground water in Goshute-Antelope Valley, Elko County, Nevada, in Contributions to the hydrology of eastern Nevada: Nev. State Engineer Water Res. Bull. 12, p. 7-8, 19-34, 1 pl.

Chief aquifers are beds of sand and gravel underlying the alluvial apron and valley floor. Reconnaissance indicates that the average recharge and discharge are both about 10,000 acre-ft per yr. Under extensive develop- 
ment about one-fourth of this could be recovered by wells. The amount of water stored in the sediments is large-a change of stage of $1 \mathrm{ft}$ is estimated to involve roughly 36,000 acre-ft of water.

Data include 16 well records, 1 well $\mathrm{log}$, and 4 chemical analyses. A map shows water levels in the valley and reconnaissance geology (scale 1:250,000).

1950. Preliminary report on ground water in Fish Lake Valley, Nevada, and California: Nev. State Engineer Water Res. Bull. 11, 33 p., 2 pls.

From 15,000 to 20,000 acre-ft per yr more can be withdrawn than was pumped in 1949.

Data include 8 well records, 8 chemical analyses, and a reconnaissance land classification by H. C. Mason. Reconnaissance methods were used to estimate ground-water recharge and discharge.

1951a. (and Maxey, G. B.). Ground water in Ruby Valley, Elko and White Pine Counties, Nevada, in Contributions to the hydrology of eastern Nevada: Nev. State Engineer Water Res. Bull. 12, p. 10-12, 65-93, pl. 2.

Chief aquifers are permeable beds in the alluvial apron and the younger unconsolidated deposits underlying the floor of the valley. Annual recharge is about 68,000 acre-ft; discharge is mainly through transpiration by phreatophytes.

Data include 23 well records, 1 well $\log , 3$ chemical analyses, and reconnaissance geologic map (scale about 1:125,000).

1951b. (and Maxey, G. B.). Ground water in the Clover and Independence Valleys, Elko County, Nevada, in Contributions to the hydrology of eastern Navada: Nev. State Engineer Water Res. Bull. 12, p. 12-14, 95-125, pl. 3.

Chief aquifers are permeable beds in the lower parts of the alluvial apron and the younger unconsolidated deposits underlying the floor of the valley. Average annual recharge is about 21,000 acre-ft in Clover Valley and about 9,000 acre-ft in Independence Valley. Recoverable ground water is about 10,000 acre-ft per $\mathrm{yr}$ in the former and about 2,000 acre-ft per $\mathrm{yr}$ in the latter.

Data include 22 well records, 1 well $\mathrm{log}$, and a reconnaissance geologic map (scale about 1:125,000).

\section{Edwards, George J.}

1951. A preliminary report on the electrical-resistivity survey of Medicine Lake, Montana: U. S. Geol. Survey Circ. 97, 16 p., 9 figs.

In the vicinity of Medicine Lake, Montana, known information from well logs and tests on outcrops of the Fort Union formation was correlated with resistivity depth profiles. Resistivity data were used to prepare a bedrocksurface map and 6 cross sections. The map shows a bedrock channel under Medicine Lake but does not establish the direction of flow of the stream that occupied it.

\section{Eisenlohr, W. S., Jr.}

1948. Effect of water temperature on flow of a natural stream: Am. Geophys. Union Trans., v. 29, no. 2, p. 240-242, 3 figs.

About 3 percent of the variation in streamflow of the Kootenai River near Copeland, Idaho, has been found to be associated with variation in water temperature. 
Ellis, W. C. See also Barnes, J. R., 49.

1949. Ground-water resources of Borden County, Texas: Tex. Board Water Engineers dupl. rept., 26 p., 2 figs.

None of the aquifers can yield supplies of water adequate for irrigation or heavy industrial use.

Data for the 914-sq-mi area include 129 well records, 41 well $\operatorname{logs}$, and 84 chemical analyses. A geologic map is based on the 1937 geologic map of Texas.

Engler, Kyle. See Counts, H. B., 54 .

Fader, Stuart W. See also Nace, R. L., 50; West, S. W., 52.

1951a. Water levels in wells and lakes in Rathdrum Prairie and contiguous areas, Bonner and Kootenai Counties, northern Idaho: U. S. Geol. Survey dupl. rept., 90 p., 1 pl., 1 fig.

Data are given for a $270-\mathrm{sq}-\mathrm{mi}$ area.

1951b. Records of wells and ground-water withdrawals for irrigation in Raft River valley, Cassia County, Idaho: U. S. Geol. Survey dupl. rept., 141 p., 1 pl., 1 fig.

Data for the $800-$ sq-mi area include 284 well records, 29 well $\operatorname{logs}$, and well-discharge measurements.

1954. An analysis of contour maps of water levels in wells in southwestern Louisiana, 1952-53; La. Geol. Survey and La. Dept. Public Works Water Res. Pamph. 1, 7 p., 4 pls., 1 fig.

Pumpage in 1953 from the principal (Chicot) aquifer was 619,000 acre-ft, mainly for rice irrigation. Water levels are declining about $1 \mathrm{ft}$ per year. Four water-level maps, for April and September 1952, and April and September-October 1953, cover 13 parishes.

1955. An analysis of contour maps of water levels in wells in southwestern Louisiana, 1954: La. Geol. Survey and La. Dept. Public Works, Water Res. Pamph. 2, 11 p., 2 pls., 5 figs.

Pumpage in 1954 from the Chicot aquifer was 642,000 acre-ft. Two waterlevel maps, for March and September 1954, are included.

Fent, 0. S.

1950. Geology and ground-water resources of Rice County, Kansas: Kans. Geol. Survey Bull. 85, 142 p., 11 pls., 11 figs.

The chief aquifers are Pleistocene sand and gravel, the Dakota sandstone, and sandstone beds in the Kiowa shale. Water of high chloride content is found in some of the Permian rocks, in deep Pleistocene channels, and in shallow deposits where highly mineralized industrial wastes are discharged.

Basic data for the 721-sq-mi area include 266 well records, 64 test-hole logs, 1 measured geologic section, 43 comprehensive chemical analyses, and 89 chloride determinations. Hydrologic maps show water levels, saturated thickness of Tertiary and Quaternary deposits, and ground-water regions. Other illustrations include 6 geologic cross sections, a bedrock-surface map, and an areal geologic map (scale about 1:125,000).

\section{Ferguson, George E.}

1947. (and Lingham, C. W., Love, S. K., and Vernon, R. O.). Springs of Florida: Fla. Geol. Survey Bull. 31, 196 p., 1 pl., 37 figs.

The springs of Florida are described as to their general geography, geology, 
hydrology, and chemistry. Discharge measurements and other data are given for many of the springs.

\section{Ferguson, Harry F.}

1953. The ground-water resources, in The water resources of St. Marys County (Md.): Md. Dept. Geology, Mines, and Water Res. Bull. 11, p. $16-195$, pls. $3-7$, figs. 4-5.

The chief aquifers, all of Eocene age, are the Aquia greensand, the Nanjemoy formation, and sediments of Jackson age. Potentially important aquifers in Cretaceous deposits are the Patuxent, Patapsco, and Magothy formations.

Data for the 367 -sq-mi area include 480 well records, 27 test-hole logs, 258 well logs, and 30 chemical analyses. Illustrations include 2 geologic cross sections and maps showing the top of the Aquia greensand, the base of the Calvert formation, and the base of lowland Pleistocene deposits. Yield and specific-capacity data are given for wells in the Aquit greensand, Nanjemoy formation, and sediments of Jackson age.

Ferris, John G. See also Brown, R. H., 46.

1948. Ground-water hydraulics as a geophysical aid: Mich. Geol. Survey Div. Tech. Rept. 1, 12 p., 11 figs.

The method of images is used with aquifer-test data to interpret local geology.

1949. Ground water, in Wisler, C. O., and Brater, E. F., Hydrology: New York, John Wiley and Sons, chap. 7, p. 198-272, figs. 62-98.

This chapter is devoted to the physics and hydraulics of ground water. The introductory material discusses porosity, mechanics of interstitial flow, permeability and transmissibility, specific yield, and other properties of the aquifers and their contained water. The major and final part is devoted to ground-water hydraulics. An adjustment of test data is outlined so that the nonequilibrium formula can be applied to thin aquifers. The method of images is explained to permit nonequilibrium methods to be used where the aquifer is intercepted by boundaries. The water-budget method of studying ground water is described and artificial recharge is briefly reviewed.

1950a. A quantitative method for determining ground-water characteristics for drainage design: Agr. Eng., v. 31, no. 6, p. 285-289, 291.

A drain function is derived for determining coefficients of transmissibility and storage for an aquifer intersected by a drain of constant discharge.

1950b. Prospecting for ground water-pumping tests: Am. Water Works Assoc. Jour., v. 42, no. 10, p. 959-962.

Describes briefly the important factors to consider in aquifer tests. Cites several successful applications of aquifer-test data.

1950c. Water spreading and recharge wells: Ind. Water Conserv. Conf. Proc., p. 52-59.

Surface methods of recharge consist of sheet flooding, basin flooding, and channel flooding. Subsurface methods consist of areal dispersion (in pits or mines), linear dispersion (ditch-and-furrow, trenches or canals, or galleries), and point dispersion (wells or shafts). Examples are described, and a table summarizes reported rates of percolation for various methods at several localities. 
1951a. Cyclic fluctuations of water levels as a basis for determining aquifer transmissibility: Internat. Union Geodesy and Geophysics, Internat. Assoc. Sci. Hydrology, Brussels, 1951, v. 2, p. 148-155, 5 figs.

Formulas are developed and specific examples are given to demonstrate that observations of lag, velocity, and wave length of sinusoidal changes in ground-water level, such as are produced by tidal influences, may be used to determine aquifer transmissibility and storage coefficients.

1951b. Ground-water aquifers as waste-disposal reservoirs; an outline of the basic hydrologic problems involved: Manufacturing Chemists Assoc. 6th Ann. Pollution Abatement Conf. Trans., p. 68-74.

Outlines hydrologic principles and discusses problems related to the practice of disposing of wastes into ground-water reservoirs.

1954. (and Burt, E. M., Stramel, G. J., and Crosthwaite, E. G.). Groundwater resources of southeastern Oakland County, Michigan: Mich. Geol. Survey Div. Progress Rept. 16, 158 p., 6 pls., 44 figs.

The chief aquifers are alluvial deposits bordering present streams and buried outwash deposits of preglacial or interglacial streams. Locally, rocks of Devonian and Mississippian age are sources of highly mineralized water, but locally yield small potable supplies. About two-thirds of the annual rainfall is lost by evapotranspiration. This loss is 6 times the combined withdrawal by all ground-water users in the area. Annual water loss by overland runoff during storms generally equals or exceeds ground-water use. Thus, salvage of water discharged by evapotranspiration and storm runoff represents a method of increasing overall water supplies.

Data for the 318-sq-mi area include about 1,000 well records, 482 well logs, and 76 chemical analyses. Subsurface dams are mentioned briefly (p. 63). Hydraulic diffusivity is defined (p. 97). Maps show geology of bedrock and surficial deposits (scale about 1:180,000).

1955. (and Sayre, A. N.). The quantitative approach to ground-water investigations: Econ. Geology, Fiftieth Anniversary Volume, 19051955, pt. 2, p. 714-747, 1 fig.

Reviews the history and development of quantitative methods used in ground-water investigations. Includes a selected bibliography of 221 references.

\section{Feth, John H.}

1953. A geologic and geophysical reconnaissance of the Doney ParkBlack Bill Park area, Arizona, with reference to ground water; with a section on geophysics, by Yost, C. B., Jr.: U. S. Geol. Survey Circ. 233, 11 p., 1 pl., 1 fig.

The Doney Park-Black Bill Park area occupies about 200 sq mi just east of the San Francisco Mountains near Flagstaff, Arizona. Residents of this area are dependent for domestic water almost exclusively upon precipitation caught on the roofs of buildings and stored in cisterns, because no permanent surface-water supply is available and previous attempts to develop adequate ground-water supplies have not been successful.

Six localities are considered favorable for drilling test wells: (1) near the center of Doney Park; (2) in glacial outwash gravels at the northwest end of Black Bill Park; (3) in a reentrant valley north of Little Elden Mountain; (4) in a structural(?) trap near the east base of Elden Mountain; 
(5) on the Crisp Ranch; and (6) along the channel of Rio de Flag. Infiltration galleries dug in recent cinder dunes might yield water in places where the dunes are underlain by older cinders that have partly weathered to clay. An ancient Indian "walk-in" well was recognized on the Crisp Ranch. A shaft dug in the center of the well encountered volcanic cinders welded in "fossil ice."

1954a. Investigation of geology and occurrence of ground water in the Weber Basin project area, Farmington to Willard, Utah, a progress report, in Progress report on selected ground-water basins in Utah: Utah State Engineer Tech. Pub. 9, p. 119-128, 1 fig.

A brief review of previous and current work in the basin and the objectives of the continuing investigation.

1954b. Preliminary report of investigations of springs in the Mogollon Rim region, Arizona, with sections on base flow of streams, by White, N. D., and quality of water, by Hem, J. D.: U. S. Geol. Survey dupl. rept., 77 p., 5 pl., 24 figs.

The Mogollon Rim is an escarpment in southeastern Arizona. Contact springs are most numerous in basalt-covered areas and have discharges ranging from 1 to $3,000 \mathrm{gpm}$. Faulting also is important in control of spring occurrence.

Data for the 10,000-sq-mi area include 195 spring records, 20 chemical analyses, geologic cross sections, and reconnaissance geologic maps at various scales.

Fiedler, A. G.

1948. (and McGuinness, C. L.). Ground-water problems and their relation to Army water-supply installations; presented at Water and Sewerage Conf., Office of Engineers, Baltimore, Maryland, Oct. 26, 1948: U. S. Geol. Survey dupl. rept., 12 p., 1 fig.

Reviews the ground-water work of the Geological Survey during World War II, outlines some ground-water problems that may pertain to Army activities, and describes legislation relating to ground-water control.

1950. Legal and economic aspects of underground waters, in Proceedings of Minnesota conference on underground waters: Minn. Div. Waters Bull. 2, p. 48-55.

Reviews the concepts of ground-water hydrology that bear on legal control of use of ground water. Cites as a model of its kind the New Mexico groundwater law, which was an outgrowth of the need for regulation of groundwater use in the Roswell artesian basin. Includes a bibliography of 22 items.

\section{Filaseta, Leonard}

1946. Ground water in the Fessenden area, Wells County, North Dakota:

U. S. Geol. Survey N. Dak. Ground-Water Studies 1, 22 p., 3 figs.

The only extensive aquifer in the area is the Dakota sandstone at a depth of 2,000 feet, but its soft, highly mineralized water is considered unsuitable for domestic use.

Data for the 285-sq-mi area include 60 well logs.

Fishel, Vinton C. See also Frye, J. C., 49a.

1946. Notes on the permeability coefficient and its units: Am. Geophys. Union Trans., v. 27, no. 2, p. 256-259. 
Examples are given of some terms in heat and electricity to illustrate the use of the word "coefficient" and it is suggested that the word "coefficient" should be dropped from the expression "coefficient of permeability." Objections are given to several permeability terms. It is then suggested that the quality of a material that has been known as the coefficient of permeability or laboratory coefficient of permeability be called "specific permeability" in comparison with the use of the term "specific resistance." If the permeability is determined for other than standard conditions (field conditions) the word "specific" should be omitted.

1947. Ground-water resources of Kansas: Kans. Acad. Sci. Trans., v. 50, no. 2, p. 105-114, 3 figs.

Ground-water supplies are used by 321 out of 381 municipal water supplies in Kansas. The ground-water investigations made in Kansas are reviewed and the needs for such investigations are explained.

1948a. Ground-water resources of the Kansas City, Kansas, area: Kans. Geol. Survey Bull. 71, 109 p., 3 pls., 12 figs.

The chief aquifer is alluvium of the Kansas River and Missouri River valleys. In a cross section of the Missouri Valley $2.1 \mathrm{mi}$ wide, the alluvium averages $95 \mathrm{ft}$ thick. Five cross sections in the Kansas River valley show average thicknesses of alluvium ranging from 51 to $77 \mathrm{ft}$ and valley widths ranging from 1.0 to $1.6 \mathrm{mi}$. Wells inventoried in the Missouri River valley have an average yield of $980 \mathrm{gpm}$ and an average specific capacity of 180 gpm per ft. The 29 wells inventoried in the Kansas River valley have an average yield of $650 \mathrm{gpm}$ and an average specific capacity of $60 \mathrm{gpm}$ per ft. Chloride is a contamination problem in the Argentine, Armourdale, and Central industrial districts.

Basic data for the 11-sq-mi area include 167 well records, 59 test-hole logs, 67 well logs, and 76 chemical analyses. Results are given for aquifer tests of alluvium. Maps show bedrock surface, thickness of saturated alluvium, and areal geology (scale about 1:48,000).

1948b. Ground-water resources of Republic County and northern Cloud County, Kansas: Kans. Geol. Survey Bull. 73, 194 p., 12 pls., 6 figs.

Chief aquifers in the area are the Belleville formation and Dakota sandstone and, in the Republican River valley, the alluvium. Test drilling revealed that the ancestral Republican River entered Republic County 5 mi south of the Nebraska State line, crossed the present channel near Republic City, and entered Nebraska near Chester. Locally, in northern Cloud County, water in the alluvium is mineralized. Water from the Dakota sandstone is relatively soft and fresh in areas of outcrop, but highly mineralized elsewhere.

Basic data for the 899-sq-mi area include 291 well records, 113 test-hole logs, 53 well $\operatorname{logs}$, particle-size analyses, laboratory determinations of permeability of alluvium, measured geologic sections, and 58 chemical analyses. Illustrations include 6 geologic cross sections and maps showing water levels, bedrock surface, and areal geology (scale about 1:125,000).

1952a. Fluctuations of ground-water levels, in Kansas-Missouri floods of 1951: U. S. Geol. Survey Water-Supply Paper 1139, p. 229-234.

Highest water levels of record occurred in 2 observation wells during the flood period.

1952b. Ground-water resources of Pawnee Valley, Kansas: Kans. Geol. Survey Bull. 94, 144 p., 6 pls., 12 figs. 
Chief aquifers are alluvium of valleys, terrace deposits where saturated, and the Ogallala formation.

Data for the 360 -sq-mi area include 316 well records, 111 test-hole logs, 8 well logs, water-level data, and 70 chemical analyses. Interpretive studies include relation between ground and surface water in area, and $\mathbf{5}$ aquifer tests of alluvium. Illustrations include 12 geologic cross sections and maps showing depth to water, bedrock surface, and areal geology (scale 1:130,000).

1953. (and Searcy, J. K., and Rainwater, F. H.). Water resources of the Kansas City area, Missouri and Kansas: U. S. Geol. Survey Circ. 273, 52 p., 2 pls., 28 figs.

This report contains information on the quantity and quality of water in a 1,330-sq-mi area including parts of Clay, Jackson, and Platte Counties, Missouri, and Wyandotte and Johnson Counties, Kansas. Present use of water in the area is about $700 \mathrm{mgd}$. The extent of the alluvium and the thickness of saturated material are shown on maps. The availability and quality of ground water from the alluvium is discussed for each of five industrial districts. The principles of induced infiltration are discussed and the possibilities of its greater application are evaluated. The public water supplies are described. Tables and graphs show the chemical quality and the temperature of water from ground and surface sources and from the public supplies. Laws affecting the use of water in the area are described briefly and the water-resources potential of the area is evaluated.

1955. (and Leonard, A. R.). Geology and ground-water resources of Jewell County, Kansas: Kans. Geol. Survey Bull. 115, 152 p., 12 pls., 24 figs.

On the whole, ground-water supplies are small. The ground water is generally hard but otherwise suitable for most uses, except for water from certain wells which is excessively high in dissolved solids or in nitrate. In a year of normal precipitation the water levels have a normal cumulative rise of about $2.86 \mathrm{ft}$. In a year of no precipitation the net decline of water levels would be about 4.6 feet.

Data for the 915-sq-mi county include 259 well records, 13 test-hole logs, 36 chemical analyses, 9 measured sections, a fossil list, and data for an aquifer test of alluvium at Jewell City. Graphs show relation of annual net change on water levels to annual cumulative rise of water levels, annual cumulative decline of water levels to annual cumulative rise of water levels, and annual cumulative decline of water levels to annual net change of water levels. Maps show physiographic divisions, depth to water, and areal geology (scale 1:125,000).

Fix, Philip F. See also Brannock, W. W., 48.

1949. Regularity of Old Faithful Geyser, Yellowstone National Park, Wyoming: Am. Jour. Sci., v. 247, no. 4, p. 246-256, 1 pl.

From records for $1870-1947$, the average interval between the beginning of eruptions is 65.12 minutes, which is surprisingly close to the 65.1 minutes observed in 1878. Since its discovery in 1870 the behavior of Old Faithful has not changed fundamentally in any way, although its idiosyncrasies have become better known.

1950. (and others). Ground water in the Escalante Valley, Beaver, Iron, and Washington Counties, Utah-a progress report, with a section on Ground water in the Beryl-Enterprise district, by Lofgren, B. E., 
and a section on Ground water in the Milford district, by Nelson, W. B.: Utah State Engineer Tech. Pub. 6, in 27th Bienn. Rept., p. 109-210, 10 pls., 14 figs.

Chief aquifers are gravel and sand beds in unconsolidated valley fill. In the Beryl-Enterprise district the pumpage in 1950 of 50,000 acre-ft was several times greater than the annual recharge. Natural discharge, believed to be less than 10,000 acre-ft per yr, can be eliminated economically only by extensive mining of ground water in the higher areas now under cultivation, because the low medial part of the district contains excessive alkali in its soil. The chief problem in the Milford district is decline in ground-water recharge that might result from proposed changes in the pattern of diversion of Beaver River water.

Data include 315 well records, pumpage figures, and 142 chemical analyses. Maps show water levels in the Milford and Beryl-Enterprise districts and areal geology of the Beryl-Enterprise district (scale about 1:110,000).

Fluellen, J. R. See also Winslow, A. G., 52.

1952. (and Goines, W. H.). Water resources of Waller County, Texas: Tex. Board Water Engineers Bull. 5208, 57 p., 8 figs.

The county is underlain by Coastal Plain sediments dipping southeastward at an angle slightly greater than the slope of the land, thus favoring the occurrence of artesian water. The chief aquifers are the Catahoula sandstone; Oakville sandstone and Lagarto clay, undifferentiated; Willis sand; and Lissie formation. Electric logs indicate that potable water extends as deep as 2,400 ft in the Catahoula sandstone. Ground-water use is chiefly for rice irrigation and has caused an average rate of water-level decline of $1.4 \mathrm{ft}$ per year from 1942 to 1951 .

Data for the 507-sq-mi area include 212 well records, 37 well logs, periodic water-level measurements in 20 wells and 44 comprehensive and 34 partial chemical analyses. Facsimiles of electric logs are arranged to form 3 cross sections. A water-level map shows contours for 1942 and 1951. A geologic map (scale about $1: 800,000$ ) is based on the 1937 geologic map of Texas.

Foley, Frank C.

1947. (and Drescher, W. J., and Hendrickson, G. E.). Ground-water studies in Wisconsin: Am. Water Works Assoc. Jour., v. 39, no. 4, p. 369-379, 5 figs.

Reviews geology of Wisconsin and describes the early stages (1946) of the current ground-water investigations.

1950. Sedimentation and ground water, in Trask, Parker D., ed., Applied sedimentation: New York, John Wiley \& Sons, p. 113-123.

A brief review of various geologic environments as sources of ground water.

1953. (and Walton, W. C., and Drescher, W. J.). Ground-water conditions in the Milwaukee-Waukesha area, Wisconsin: U. S. Geol. Survey Water-Supply Paper 1229, 96 p., 8 pls., 27 figs.

The Milwaukee-Waukesha area includes all of Milwaukee County and the eastern half of Waukesha County. The three major aquifers are Cambrian and Ordovician sandstones, the Niagara dolomite of Silurian age, and Pleistocene sand and gravel. Ground-water use in 1949 was $38.5 \mathrm{mgd}$. Available recharge to the sandstone aquifer is estimated to be $60 \mathrm{mgd}$. Data from aquifer tests are used to compute future declines of water levels 
and to locate the effective recharge boundary. The ground water is hard, having calcium and magnesium as predominant cations, and is relatively high in sulfate.

Data include 138 selected well records, 14 well logs, 30 hydrographs of water levels, 36 chemical analyses, and results for aquifer tests of the sandstone aquifer. Illustrations include 7 geologic-hydrologic cross sections, graphs of calculated decline in water level due to pumping, and maps showing bedrock surface (scale about 1:250,000), water levels in the Niagara dolomite, water levels in the sandstone aquifer, top of the St. Peter sandstone, and bedrock geology (scale about 1:400,000).

Follett, Clarence R. See also Sundstrom, R. W., 50.

1946. (and Dante, J. H.). Floyd County, Texas; records of wells, drillers' logs, water analyses, and map showing locations of wells: Tex. Board Water Engineers dupl. rept., 101 p., 1 pl.

Data for the 993-sq-mi county include 726 well records, 111 well logs, 90 chemical analyses, and periodic measurements of depth to water in 43 wells.

1947. Ground-water resources of Brazoria County, Texas: Tex. Board Water Engineers dupl. rept., 101 p.

The chief aquifers are sands in the Beaumont clay and, in the northern part of the county, the Willis and Goliad sands.

Data for the 1,441-sq-mi area include 655 well records, 149 well logs, and 134 comprehensive and 147 partial chemical analyses.

1949. (and White, W. N., and Irelan, Burdge). Occurrence and development of ground water in the Linn-Faysville area, Hildalgo County,

Texas: Tex. Board Water Engineers dupl. rept., 43 p., 1 fig.

The chief aquifers are sands in the upper and lower parts of the Goliad sand. Amounts of ground water used in 1948 for irrigation of about 8,000 acres are given for both saturated and sprinkler applications.

Data for the 250-sq-mi area include 131 well records, 30 well logs, and chemical analyses.

1953a. Records of water-level measurements in Hale County, Texas, 1910-53: Tex. Board Water Engineers Bull. 5302, 43 p., 1 fig.

Periodic measurements of depth to water are given for 157 wells.

1953b. Records of water-level measurements in Lubbock County, Texas, 1936-53: Tex. Board Water Engineers Bull. 5303, 33 p., 1 fig.

Periodic measurements of depth to water are given for 150 wells.

1953c. Records of water-level measurements in Deaf Smith County, Texas, 1914-53: Tex. Board Water Engineers Bull. 5305, 22 p., 1 fig.

Periodic measurements of depth to water are given for 63 wells.

1953d. Records of water-level measurements in Floyd County, Texas, 1913-53: Tex. Board Water Engineers Bull. 5304, 27 p., 1 fig.

Periodic measurements of depth to water are given for 98 wells.

1953e. Records of water-level measurements in Lamb County, Texas, 1914-53: Tex. Board Water Engineers Bull. 5306, 19 p., 2 figs.

Periodic measurements of depth to water are given for 64 wells.

1953f. Records of water-level measurements in Swisher County, Texas, 1914-53: Tex. Board Water Engineers Bull. 5307, 23 p., 2 figs.

Periodic measurements of depth to water are given for 93 wells. 
1954a. Records of water-level measurements in Dallam, Hansford, Hartley, Hutchinson, Moore, Ochiltree, and Sherman Counties, Texas: Tex. Board Water Engineers Bull. 5404, 43 p., 8 figs.

Periodic measurements of depth to water are given for 76 wells in Dallam County, 19 in Hansford County, 3 in Hartley County, 2 in Hutchinson County, 10 in Moore County, 4 in Ochiltree County, and 5 in Sherman County.

1954b. Records of water-level measurements in Martin County, Texas, 1936-53: Tex. Board Water Engineers Bull. 5405, 13 p., 2 figs.

Periodic measurements of depth to water are given for 57 wells.

1954c. Records of water-level measurements in Bailey, Briscoe, Castro, Parmer, Potter, and Randall Counties, Texas: Tex. Board Water Engineers Bull. 5406, 57 p., 11 figs.

Periodic measurements of depth to water are given for 44 wells in Bailey County, 11 in Briscoe County, 34 in Castro County, 14 in Parmer County, 5 in Potter County, and 29 in Randall County.

1954d. Records of water-level measurements in Cochran, Crosby, Gaines, Hockley, Lynn, and Terry Counties, Texas: Tex. Board Water Engineers Bull. 5407, 49 p., 12 figs.

Periodic measurements of depth to water are given for 6 wells in Cochran County, 28 in Crosby County, 12 in Gaines County, 49 in Hockley County, 22 in Lynn County, and 9 in Terry County.

1954e. Records of water-level measurements in Loving and Ward Counties, Texas: Tex. Board Water Engineers Bull. 5408, 24 p., 3 figs.

Periodic measurements of depth to water are given for 8 wells in Loving County and 60 wells in Ward County.

1954f. Records of water-level measurements in Reeves County, Texas:

Tex. Board Water Engineers Bull. 5414, 30 p., 3 figs.

Periodic measurements of depth to water are given for 123 wells.

1954g. Records of water-level measurements in Culberson, Hudspeth, and Jeff Davis Counties, Texas: Tex. Board Water Engineers Bull. 5415, 31 p., 7 figs.

Periodic measurements of depth to water are given for 53 wells in Culberson County, 28 wells in Hudspeth County, and 7 wells in Jeff Davis County.

1954h. Records of water-level measurements in El Paso County, Texas:

Tex. Board Water Engineers Bull. 5417, 49 p., 3 figs.

Periodic measurements of depth to water are given for 60 wells.

1955. Records of water-level measurements in Haskell and Knox Counties,

Texas: Tex. Board Water Engineers Bull. 5503, 16 p., 4 figs.

Periodic measurements of depth to water are given for 28 wells in Haskell County and 15 wells in Knox County.

Fox, G. Sidney. See Remson, Irwin, 55a, 55b.

Fredericks, J. C. See also Robinson, T. W., 46.

1947 (1951). (and Loeltz, O. J.). Ground water in the vicinity of Elko, Nevada, in Contributions to the hydrology of eastern Nevada: Nev. State Engineer Water Res. Bull. 12, p. 8-10, 35-63, figs. 2-4.

The most favorable area for future ground-water development is northeast of Elko, along the Humboldt River plain. 
Data include 14 well records, 12 well logs, 5 chemical analyses, pumpage figures, results of an aquifer test of the Humboldt formation, and an areal geologic map (scale about 1:130,000).

\section{Frye, John C.}

1949a. (and Fishel, V. C.). Ground water in southwestern Kansas: Kans. Geol. Survey, 24 p., 2 pls., 5 figs.

This pamphlet summarizes data in 11 ground-water reports. Illustrations include 4 geologic cross sections and maps showing water levels, depth to water, and saturated thickness of the Pleistocene deposits and Ogallala formation.

1949b. (and Leonard, A. R.). Geology and ground-water resources of Norton County and northwestern Phillips County, Kansas: Kans. Geol. Survey Bull. 81, 144 p., 10 pls., 11 figs.

The chief aquifer is the Ogallala formation, which yields moderate supplies of water. The Niobrara formation yields small supplies of mineralized water. Ground-water supplies adequate for irrigation occur in terrace deposits in the major valleys.

Data for the 1,000-sq-mi area include 285 well records, 64 test-hole logs, fossil lists, 4 measured geologic sections, and 45 chemical analyses. Illustrations include a water-level map, 6 geologic cross sections, and an areal geologic map (scale about 1:85,000).

1950. (and Walters, K. L.). Subsurface reconnaissance of glacial deposits in northeastern Kansas: Kans. Geol. Survey Bull. 86, pt. 6, 158 p., 2 pls.

In northeastern Kansas, deposits resulting directly or indirectly from continental glaciation and the alluvial fills of valleys are the most important sources of ground-water supply. Data include 6 geologic cross sections.

1954. (and Leonard, A. R.). Some problems of alluvial-terrace mapping: Am. Jour. Sci., v. 252, no. 4, p. 242-251, 4 figs.

A terrace, when considered from surface form alone, is not properly included as an independent unit for areal geologic mapping. However, when geologic mapping is done for ground-water or engineering investigations, alluvial terraces become important because of particular characteristics of the deposits that underlie them. The result is a mapping of surface form as an index to underlying materials, which may be unsatisfactory because surface form may not everywhere indicate similar subsurface conditions. The mapping of an alluvial terrace is in fact the mapping of a lithologic, stratigraphic unit. The mapping of a terrace, or a flanking pediment surface, as a simple land form is a geomorphologic problem and out of place on an areal geologic map.

Garrett, Arthur A. See also Piper, A. M., 53b; Poland, J. F., 48.

1949. (and Thomasson, H. G.). Ground-water outflow from the Chino basin, California, and the controlling geologic and hydrologic conditions: U. S. Geol. Survey dupl. rept., 143 p., 19 pls.

The ground-water outflow from the Chino basin to the Santa Ana River valley averaged about 37,000 acre-ft per yr from 1930 to 1946 . Outflow was measured indirectly but involved using a ground-water rating curve for the adjoining Temescal basin. 
Data include tables of stream discharge, consumptive use, ground-water outflow by years, 3 well-log sections, water-level profiles, and 2 water-level maps.

\section{Gatewood, J. S.}

1950. (and Robinson, T. W., Colby, B. R., Hem, J. D., and Halpenny, L. C.). Use of water by bottom-land vegetation in lower Safford Valley, Arizona: U. S. Geol. Survey Water-Supply Paper 1103, 210 p., 5 pls., 45 figs.

The lower Safford Valley, Graham County, Arizona, is an alluvial plain 1 to 3 miles wide along the Gila River. The valley is underlain to an average depth of about $100 \mathrm{ft}$ by silt and water-bearing sand and gravel. In the bottom lands bordering the river is a belt of phreatophytes, the principal ones of which are saltcedar, baccharis, cottonwood, and mesquite. Data were obtained for estimating the quantity of water that would be released to the Gila River if this vegetation were destroyed. Six methods were employed to determine the use of water: tank method, transpirationwell method, seepage-run method, inflow-outflow method, chloride-increase method, and slope-seepage method. The report describes in detail the procedures and equipment employed with each method, and the results obtained by the several methods. Their probable accuracy and sources of error also are discussed in detail.

Gaum, Carl H. See also Winslow, A. G., 54c.

1953. High Plains, or Llano Estacado, Texas-New Mexico, in Subsurface facilities of water management and patterns of supply-type area studies: U. S. Cong., House Comm. Interior and Insular Affairs, Phys. and Econ. Found. Nat. Res., v. 4, chap. 6, p. 92-104, 11 figs.

In 1951, more than 2 million acre-ft of water was pumped from wells in the Llano Estacado. Practically all this water can be considered as having been mined because recharge is negligible by comparison and natural discharge has not yet been affected. The Ogallala formation is the dominant aquifer, and where it is thin or absent, ground-water supplies are poor. The aquifer contains about 150 million acre-ft of water. Because this is an exhaustible supply, alternative sources would be needed if irrigation agriculture were to be continued indefinitely. The only obvious source is the Canadian River.

George, William O. See also Barnes, J. R., 49; Dale, O. C., 54.

1942. (and Rose, N. A.). Ground-water resources of Forth Worth and vicinity, Texas: Tex. Board Water Engineers dupl. rept., 23 p., 1 map.

Chief aquifers are sands of the Glen Rose limestone, the Paluxy sand, and sands in the Travis Peak formation.

Data include 115 well records and 6 well logs.

1945. (and Barnes, B. A.). Results of tests on wells at Waco, Texas: Tex. Board Water Engineers dupl. rept., 17 p., 4 figs.

Data include 2 well $\operatorname{logs}, 5$ chemical analyses, and aquifer-test results for sands of the Travis Peak formation of the Trinity group. The aquifer-test results are used to compute theoretical declines in water levels.

1947. Ground water in the Linn district, north-central Hidalgo County,

Texas: Tex. Board Water Engineers dupl. rept., 8 p., 1 fig.

Data include 29 well records, 1 well $\log$, and 13 chemical analyses. 
1948. Development of limestone reservoirs in Comal County, Texas: Am. Geophys. Union Trans., v. 29, no. 4, p. 503-510, 5 figs.

Lower Cretaceous limestones form one of the most extensive aquifers in Texas. Normal faulting has connected the limestones to form a hydrologic unit that is partly artesian and partly unconfined. The Edwards limestone is almost uniformly permeable from top to bottom.

1950. The salt-water problem in Texas: World Oil, v. 130, no. 2, p. 56-58, 2 figs.

Describes the occurrence of ground water as related to requirements for "surface" casing in oil wells in Texas, to protect fresh ground water.

1951a. (and Hastings, W. W.). Nitrate in the ground water of Texas: Am. Geophys. Union Trans., v. 32, no. 3, p. 450-456, 4 figs.

Public water supplies of 27 towns and cities in Texas contained more than $50 \mathrm{ppm}$ of nitrate. Of 20,000 wells sampled, about 15 contained more than $20 \mathrm{ppm}$ of nitrate. Most of the high nitrate in ground water is found in wells less than 200 feet deep, and mainly in water of late Tertiary and Quaternary formations. The presence of high nitrate appears to be unrelated to rainfall, geography, or cultivation. High nitrate may be of bacterial origin, but it is often associated with high content of other salts. The disappearance of nitrate at depth also needs explaining.

1951b. (and Romberg, F. E.). Tide-producing forces and artesian pressures: Am. Geophys. Union Trans., v. 32, no. 3, p. 369-371, fig. 1; discussion by Tom Culbertson and closing discussion by authors, v. 33 , no. 4 , p. 597-600, figs. $2-3$.

The relation of changes in both gravity and barometric pressure to artesian pressure are shown by simultaneous measurements. Computed tide-producing forces also are shown. The curves are generally conformable.

1952a. Geology and ground-water resources of Comal County, Texas, with sections on surface-water runoff by Breeding, S. D., and chemical character of the water by Hastings, W. W.: U. S. Geol. Survey Water-Supply Paper 1138, 126 p., 6 pls., 7 figs.

Comal Springs, the largest in the Southwest, issue from the Edwards limestone at an average rate of about $320 \mathrm{cfs}$, or about $200 \mathrm{mgd}$. The water discharged at Comal Springs is derived from a large area to the west and southwest, about two-thirds of it from beyond the drainage area of Cibolo Creek, the most obvious source of recharge. All the rocks exposed in the county are of Cretaceous age, except surficial deposits of Pliocene and Pleistocene age. Ground water is recharged largely by loss of water from streams where they cross the northeasterly trending faults of the Balcones fault system. The Edwards and Glen Rose limestones are the most important ground-water reservoirs and conduits.

Data for the 567-sq-mi county include 385 well records, 18 well logs, periodic water-level measurements, 350 chemical analyses, a measured section, and a fossil list. Illustrations include a water-level map, a geologic cross section, and a geologic map (scale 1:96,000).

1952b. Recharge of Texas' underground water reservoirs: U. S. Geol. Survey dupl. rept., $7 \mathrm{p}$.

A very generalized discussion of several artificial-recharge operations.

1952c. (and Doyel, W. W.). Ground-water resources in the vicinity of 
Kenmore Farms, Kendall County, Texas: Tex. Board Water Engineers Bull. 5204, 15 p., 2 figs.

Data for the 3 -sq-mi area include 23 well records, 8 well $\operatorname{logs}$, and 7 chemical analyses.

Gianella, V. P. See Brannock, W. W., 48.

Goines, William H. See also Fluellen, J. R., 52.

1951. (and Winslow, A. G., and Barnes, J. R.). Water supply of the Houston Gulf Coast region: Tex. Board Water Engineers Bull. 5101, 16 p., 23 figs.

A map shows areas and amounts of ground-water withdrawals and 6 illustrations show relation of withdrawal to water levels. There are 2 hydrologic cross sections, one of which shows the chief aquifers in the region, and the other of which shows ground-water levels for five different years from 1928 to 1950 . A graph shows the relation of temperature, hardness, chloride, and dissolved solids to depth.

Gordon, Ellis D. See also Dingman, R. J., $54 \mathrm{~b}$.

1949. Sampling procedures for rotary-drilled wells: Water Well Jour., v. 3 , no. 6 , p. 19-21, 3 figs.

Outlines a continuous sampling method and describes a table used for examination of well cuttings.

1953. (and Withington, C. F., and Dow, V. T.). Practices and results obtained with sample collectors for wagon-drill cuttings: U. S. Geol. Survey dupl. rept. TEI-213, 23 p., 4 figs.

The wagon drill is a percussion-type drill mounted on a truck or halftrack. Compressed air is used to operate the drill and to blow the cuttings from the hole. Tests were made of three sampling devices used for collecting cuttings.

Graeff, George D., Jr. See Carlston, C. W., 55.

Graham, Jack B. See also Adamson, J. H., Jr., 49b; Mangan, J. W., 53.

1945. Occurrence of ground water in the Triassic area of Pennsylvania as influenced by geology: Pa. Water Works Operators Assoc. Jour., v. 17, p. $86-98$.

Describes the sedimentary rocks and the relation between type of rock and yield and quality of ground water. Describes the Stockton, Brunswick, and Lockatong formations, of which the Stockton is most productive.

1946. Ground water for industrial use in the United States: Paper Trade Jour., v. 123, no. 5, p. 35-41, 6 figs.

A review of industrial use of ground water based on published material.

1947. Water under Penn's woods, an industrial asset: Pa. Dept. Internal Affairs Monthly Bull., v. 15, no. 7, p. 3-8; no. 8, p. 23-30.

A brief review of ground-water development from biblical times to the present with general application to Pennsylvania.

1949. How the rocks of Pennsylvania were formed and their influence on the quality of the public water supply: Pa. Water Works Operators' Assoc. Jour., v. 21, 16 p., 3 figs.

Reviews the geologic history of Pennsylvania and relates the chemical quality of water to the geology. 
1950a. Ground-water problems in the Philadelphia area: Econ. Geology, v. 45 , no. 3 , p. $210-221,5$ figs.

The Fall Line separates the Philadelphia area into an area of highly productive sand and gravel aquifers in the Coastal Plain and an area of less productive bedrock aquifers in the Piedmont Plateau. The chief aquifer is the Raritan formation, which is recharged mainly by infiltration from the Delaware and Schuylkill Rivers. The quality of the infiltrating water is deteriorating because it has to percolate through river-bottom sediments that contain coal culm, raw sewage, and industrial wastes.

Illustrations include 2 geologic cross sections and a generalized geologic map (scale about 1:700,000).

1950b. Pennsylvania's water resources and water uses: Pa. Acad. Sci. Proc., v. 24, p. 220-229.

A general discussion of the source of water, the interrelation of surface and ground water, the chemical quality of water, and water-resources programs in the State.

1951a. Ground-water problems of Pennsylvania: U. S. Geol. Survey dupl. rept., $13 \mathrm{p}$.

Problems include water-level declines caused by large ground-water withdrawals for air conditioning in Pittsburgh and induced recharge of chemically inferior waters into the principal aquifer at Philadelphia.

1951b. (and Mangan, J. W., and White, W. F., Jr.). Water resources of southeastern Bucks County, Pennsylvania: U. S. Geol. Survey Circ. 104, 21 p., 1 pl., 12 figs.

The 90 -sq-mi area of southeastern Bucks County covered by this report has sufficient water of generally satisfactory chemical quality to satisfy prospective domestic and industrial requirements in the area. Maps show the configuration of the bedrock surface below the valley plain and areas of low and high ground-water yield. Development of large ground-water supplies by induced infiltration from the Delaware River is discussed.

1952. Ground-water use in the United States: Water Well Jour., v. 6, no. 3, p. $8-11,18,21-22,26,28,6$ figs.

Reviews the use of ground water in the United States and mentions the types of ground-water reports available.

Greenman, David W. See also Noecker, Max, 54.

1955. Ground-water resources of Bucks County, Pennsylvania: Pa. Topog. and Geol. Survey Bull. W-11, 66 p., 2 pls., 1 fig.

Chief aquifers include unconsolidated Cretaceous and Quaternary deposits which underlie the lowlands along the Delaware River below Morrisville. Ground-water supplies in Triassic rocks, especially the Stockton lithofacies, far exceed the present rate of withdrawal, in spite of the rather low permeability of the rocks.

Data for the 617-sq-mi county include 652 well records, 73 chemical analyses, and an areal geologic map (scale 1:62,500) by Bradford Willard and others with descriptions of the water-bearing formations by J. C. Kammerer.

\section{Griggs, Roy L.}

1948. Geology and ground-water resources of the eastern part of Colfax County, New Mexico: N. Mex. Bur. Mines and Min. Res. GroundWater Rept. 1, 187 p., 8 pls., 10 figs. 
Chief aquifers are the Dakota sandstone and Ogallala formation. The Dakota sandstone occurs at shallow to moderate depths in the eastern and south-central parts of the county, but its water is of poor quality in the south-central part. The Ogallala formation is present in the southeastern corner of the county but only the lower 10 to $20 \mathrm{ft}$ of the formation is saturated. This water is of good quality. The Greenhorn limestone and Fort Hays limestone member of the Niobrara formation furnish water of fair quality at short distances down dip from their outcrops. In the central part of the county where the Niobrara formation and Pierre shale are thick, ground-water supplies are scant but potable water is present in places in the alluvium along streams.

Data include 283 well and 40 spring records, 102 chemical analyses, and results of aquifer tests of the Ogallala formation. Maps show ground-water areas, top of the Dakota sandstone, and areal geology (scale 1:125,000).

1951. (and Hendrickson, G. E.). Geology and ground-water resources of San Miguel County, New Mexico: N. Mex. Bur. Mines and Min. Res. Ground-Water Rept. 2, 121 p., 6 pls., 2 figs.

In the plains area, chief aquifers are sandstone beds in the Santa Rosa and Chinle formations. On the Las Vegas Plateau the Dakota and Purgatoire formations are the chief aquifers, although some water generally unfit for domestic use is obtained from the Graneros shale and the Greenhorn limestone. On Glorieta Mesa, most wells draw from the Yeso formation. In the Sangre de Cristo Mountains, water can be obtained from alluvium in valleys and locally from limestones and sandstones.

Data for the 4,749-sq-mi county include 300 well and 22 spring records and 81 chemical analyses. Maps show ground-water areas and areal geology (scale about 1:250,000).

\section{Griffin, Margaret Saunders}

1946. Bibliography of technical reports, articles, and memoranda published or otherwise released by the Division of Ground Water during the fiscal year ended June 30, 1946: U. S. Geol. Survey dupl. list, 13 p.

1947. Bibliography of technical reports, articles, and memoranda published or otherwise released by the Division of Ground Water during the fiscal year ended June 30, 1947: U. S. Geol. Survey dupl. list, 15 p.

1948a. Bibliography of hydrology; ground water: Am. Geophys. Union Trans., v. 29, no. 2, p. 286-291.

1948b. Bibliography of technical reports, articles, and memoranda published or otherwise released by the Ground Water Branch during the fiscal year ended June 30, 1948: U. S. Geol. Survey dupl. list, 14 p.

1949. Bibliography of technical reports, articles, and memoranda published or otherwise released by the Ground Water Branch during the fiscal year ended June 30, 1949: U. S. Geol. Survey dupl. list, 18 p.

1950. Bibliography of technical reports, articles, and memoranda published or otherwise released by the Ground Water Branch during the fiscal year ended June -30, 1950: U. S. Geol. Survey dupl. list, 18 p.

1953. Bibliography of technical reports, articles, and memoranda published or otherwise released by the Ground Water Branch during the period June 30, 1950, to January 1, 1953: U. S. Geol. Survey dupl. list, $47 \mathrm{p}$. 
1954. Bibliography of technical reports, articles, and memoranda published or otherwise released by the Ground Water Branch during the calendar year 1953: U. S. Geol. Survey dupl. list, 20 p.

1955. Bibliography of technical reports, articles, and memoranda published or otherwise released by the Ground Water Branch during the calendar year 1954: U. S. Geol. Survey dupl. list, 28 p.

\section{Griswold, Ralph E.}

1951. The ground-water resources of Wayne County, New York: N. Y. Water Power and Control Comm. Bull. GW-29, 61 p., 3 pl., 8 figs.

Small supplies of ground water may be obtained from either bedrock or surficial deposits. Potentially greater supplies may be developed along the buried valley of the Fairport-Lyons channel. The Lockport dolomite and Salina formation, which are the most prolific bedrock aquifers, commonly yield water of poor quality.

Data for the 607-sq-mi county include 380 well and spring records, 24 well logs, and 38 chemical analyses. Maps show bedrock surface (scale about 1:235,000) and surficial and bedrock geology (scale about 1:160,000).

\section{Groot, J. J.}

1954. (and Rasmussen, W. C.) Geology and ground-water resources of the Newark area, Delaware, with a section on surface-water resources by A. E. Hulme: Del. Geol. Survey Bull. 2, 133 p., 10 pls., 18 figs.

The extent, thickness, and hydrologic properties of aquifers in the Newark area were investigated by canvass of existing wells, drilling and logging test holes, study of surface and subsurface geology, magnetic and resistivity surveys, electrical logging, and particle-size analyses. The perennial yield of the north ground-water basin is estimated at $722 \mathrm{gpm}$. A program of test drilling, supplemented by a surface-resistivity survey, indicated a new ground-water basin about 2 miles south of the present city well field, and two other prospects for a ground-water supply were indicated.

Data for the 13-sq-mi area include 322 well records, 44 test-hole logs, 12 well $\operatorname{logs}, 4$ measured sections, 10 chemical analyses, particle-size analyses, pumpage figures, aquifer tests of the Patuxent formation, and a geologic map (scale about $1: 45,000$ ). The report contains also a map of magnetic anomalies.

Grossman, I. G. See also Asselstine, E. S., 55.

1953. (and Yarger, L. B.). Water resources of the Rochester area, New York: U. S. Geol. Survey Circ. 246, 30 p., 2 pls., 19 figs.

In the Rochester area total water use in 1952 was about $192 \mathrm{mgd}$, including $75 \mathrm{mgd}$ for steam plants generating electric power. The present use is only a fraction of 1 percent of the estimated potential supply. Information on the chemical quality of water from the streams and principal groundwater reservoirs is given. Maps show aquifers, surface drainage, and bedrock surface. The occurrence and availability of ground water are discussed briefly, and tables show average and extreme water levels, yields, and temperatures. The public water-supply systems are described. Laws affecting the use of water in the area are described briefly, and the waterresources potential of the area is summarized.

Guyton, William F. See also Klaer, F. H., Jr., 48a.

1946. Artificial recharge of glacial sand and gravel with filtered river 
water at Louisville, Kentucky: Econ. Geology, v. 41, no. 6, p. 644-658, 5 figs.

During the spring of 1944 , about $1.7 \mathrm{mgd}$ of cold water from the municipal river-water supply was added to the principal aquifer (glacial outwash) through several supply wells. The large cone of depression resulting from prior pumping was practically filled by artificial and natural recharge. As a result, during the summer, when the city water became too warm to be used in the plants, an increased and ample supply of cold water was available from the wells.

1948. Fluctuations of water levels and artesian pressures in wells in the United States; their measurement and interpretation: Internat. Union Geodesy and Geophysics, Internat. Assoc. Sci. Hydrology, Oslo, 1948, v. 3, p. 85-93.

Reviews briefly methods used for measuring water levels, for interpreting changes in levels, and for using such measurements in aquifer tests.

1949. Estimated use of ground water in the United States, 1945; U. S. Geol. Survey dupl. rept., 5 p., 7 figs.

Total use of ground water in the United States in 1945 was estimated at $20,000 \mathrm{mgd}$. This was composed of $10,000 \mathrm{mgd}$ for irrigation, $5,000 \mathrm{mgd}$ for industrial use, 3,000 $\mathrm{mgd}$ for municipal use, and 2,000 $\mathrm{mgd}$ for rural use. Tables break these totals down by State, area, type of industry, and city.

Haigler, Leon B. See Rasmussen, W. C., 53.

\section{Halberg, H. N.}

1948. Ground-water resources of Cape Cod, Massachusetts: Natl. Cranberry Mag., v. 13 , no. 4, p. 12-13; no. 5, p. 22-24.

The principal aquifers are glacial outwash.

1949. (and Roberts, C. M.). Recovery of ground-water supplies by pumping from water-table ponds: Am. Geophys. Union Trans., v. 30, no. 2, p. $283-292,8$ figs.

Glacial deposits are infiltrated by precipitation and by pond water when the pond levels are high. The water thus stored is recovered later when the water level is lowered by pumping from the ponds.

1950. (and Pree, H. L., Jr.). Ground-water resources of the Greater Boston area, Massachusetts: Boston Soc. Civil Engineers Jour., v. 37, no. 2, p. 204-230, 10 figs.

Describes the geology of the area, the use of water, and the water-table fluctuations. Hydraulics of aquifer tests are reviewed briefly and tests on wells at Woburn, Massachusetts, are described. Water-quality data are summarized.

Most of the ground water is obtained from permeable unconsolidated deposits in buried preglacial valleys of the Charles, Malden, and Neponset Rivers, and the Aberjona-Fresh Pond (upper Mystic) valley. Only small supplies can be obtained from bedrock. Water levels indicate no appreciable decrease in ground-water storage during the period of observation.

\section{Hale, Harrison}

1947. (and Baker, R. C., Walling, I. W., Parrish, D. M., and Billingsley, G. A.). Public water supplies of Arkansas: Ark. Univ. Bur. Research. Research Ser. no. 11, 104 p. 
Data include 217 chemical analyses of public water supplies in 178 towns and cities in Arkansas. Of the supplies tested, 132 are obtained from wells and 11 from springs. Ground water serves 56 percent of the population.

Hale, W. E.

1942. (and Theis, C. V.). Memorandum on ground-water conditions in the vicinity of the city airport southwest of Carlsbad, New Mexico: N. Mex. State Engineer 14th and 15th Bienn. Rept. 1938-42, p. 221234, 1 fig. [1953].

Four possible sources of ground water for an airport were considered: (1) the Carlsbad limestone, (2) limestone beds in the Rustler formation, (3) sand and gravel in the valley fill near the Southern Canal, and (4) conglomerate beds in the valley fill. The quality of the water at the airbase site is the best in the general area, but water of poor quality might be drawn in from the east by continued pumping. A permanent supply cannot be assured if wells are drilled in alluvium at the airport site, but if such wells are drilled and later fail, an adequate supply of poorer quality water could be obtained from the Carlsbad limestone about 2 miles north of the airport site.

Data include 20 well records, 4 well $\operatorname{logs}$, and 24 chemical analyses.

1954. (and Hughes, L. S., and Cox, E. R.). Possible improvement of quality of water of the Pecos River by diversion of brine at Malaga Bend, Eddy County, New Mexico: Pecos River Comm. N. Mex. and Tex., 43 p., 8 pls., 5 figs.

An average of 370 tons of salt is added daily to the Pecos River by seeps and springs at Malaga Bend. In this stretch, the river gains an average of $2.4 \mathrm{cfs}$, of which $2 \mathrm{cfs}$ is return irrigation flow and $0.4 \mathrm{cfs}$ is nearly saturated brine. The brine occurs in the Rustler formation, which underlies the area at about $200 \mathrm{ft}$, but its source undoubtedly is the salt in the underlying Salado formation. Because the pressure head in the aquifer is above river level at Malaga Bend, an experiment is proposed to try pumping the brine from wells to the nearby Queen Lake depression for storage and evaporation. This is believed to be a way of preventing brine inflow to the river. Aquifer tests were made to determine feasibility of the project. Quality-ofwater data were used as an aid in determining movement of brine and other waters in the area. The effects of brine on the Queen Lake playa sediments are being studied to see whether brine might leak out of the depression.

1955a. Ground-water conditions in the vicinity of Rattlesnake Springs, Eddy County, New Mexico: N. Mex. State Engineer Tech. Rept. 3, 54 p., 1 pl., 9 figs.

The water from Rattlesnake Springs is used primarily for irrigation of nearby lands, but a part of the flow is piped to Carlsbad Caverns National Park for domestic use. Pumping of nearby wells southwest of the springs has a definite effect on the spring flow. The report discusses also the possible source of the flow of Blue Spring, about 11 miles downstream in the Black River valley.

Data for the 150-sq-mi area include 41 well and 8 spring records, 36 partial chemical analyses, spring-discharge measurements, periodic water-level measurements, and a map (scale about 1:150,000) showing geology, quality of water, and water levels. 
1955b. Geology and ground-water resources of Webster County, Iowa:

Iowa Geological Survey Water-Supply Bull. 4, 257 p., 16 pl., 29 figs.

The most consistently high-yielding zone of aquifers is formed by the lower part of the Prairie du Chien, the Jordan sandstone, and the St. Lawrence formation. Moderate amounts of water are obtained from the upper part of the Prairie du Chien and the St. Peter sandstone. Small to moderate amounts are obtained from rocks of Mississippian age, sandstones of Pennsylvanian age and sands and gravels in the Pleistocene drift sheets.

Data for the 718-sq-mi area include records of 345 wells, 67 analyses of well waters, logs of 29 wells, and a map of the bedrock geology (scale about 1:125,000).

Hall, Francis R. See Palmquist, W. N., Jr., 53.

Halpenny, Leonard C. See also Cushman, R. L., 55; Gatewood, J. S., 50.

1947a. (and Babcock, H. M., Morrison, R. B., and Hem, J. D.). Groundwater resources of the Duncan basin, Arizona: U. S. Geol. Survey dupl. rept., 21 p., 2 pls., 2 figs.

The chief aquifer is the sand and gravel fill of the inner valley along the Gila River. Water from the Gila River is suitable for irrigation, but water from wells is generally unsafe for irrigation and too high in fluoride for domestic use.

Data include 61 well records, 4 chemical analyses, and a generalized geologic map (scale about 1:270,000). For a more recent report, see Halpenny 52.

1947b. (and Cushman, R. L.). Ground-water resources and problems of the Cactus Flat-Artesia area, San Simon basin, Arizona, with a section on quality of water by J. D. Hem: U. S. Geol. Survey dupl. rept., 14 p., 2 figs., 3 pls.

Artesian water occurs in older alluvial fill at depths ranging from 200 to at least 1,700 ft. About 5,600 acre-ft of water flowed or was pumped from 138 wells tapping the fill, and about 1,000 acres were irrigated in 1946. The water is high in sodium and chloride content and most is "injurious to unsatisfactory" for irrigation. Some of the land has been damaged by continued use of the water. The "safe yield" of the older alluvial fill is estimated to be about 5,000 acre-ft per year, but this could be increased by plugging abandoned wells, rehabilitating leaky wells, and restricting flow to beneficial use.

Data for the 65-sq-mi area include 10 well records, 10 chemical analyses, and a geologic map (scale 1:63,360).

1947c. (and Hem, J. D., and Jones, I. I.). Definitions of geologic, hydrologic, and chemical terms used in reports on the ground-water resources and problems of Arizona, with an introduction by S. F. Turner: U. S. Geol. Survey dupl. rept., 29 p., 6 figs.

Defines the scientific terms used in a current series of Arizona groundwater reports.

1949. (and Brown, S. C.). Water-supply investigation of Fort Defiance area, Navajo Indian Reservation, Apache County, Arizona, with a section on quality of water by J. D. Hem: U. S. Geol. Survey dupl. rept., 11. p., 2 pls.

The most practical method of obtaining additional water would be to 
develop and utilize the flow of two artesian springs, Bonito Spring and Supai Spring. An adequate supply probably could not be obtained by drilling.

Data include 13 chemical analyses, a geologic cross section, and a geologic map (scale about 1:52,000).

1951. Preliminary report on the ground-water resources of the Navajo and Hopi Indian Reservations, Arizona, New Mexico, and Utah:

N. Mex. Geol Soc. Guidebook of the south and west sides of the San

Juan Basin, N. Mex. and Ariz., Second Field Conf., p. 147-151, 1 pl.

In most parts of the Navajo country sufficient ground water for livestock and domestic use can be developed, although in some areas wells as deep as 1,500 to $2,000 \mathrm{ft}$ are required to obtain sufficient water. There is little hope of developing ground water in sufficient quantity for irrigation, except from alluvium in a few places where recharge is abundant.

1952. (and others). Ground water in the Gila River basin and adjacent areas, Arizona-A summary: U. S. Geol. Survey dupl. rept., 224 p., 32 pls., 24 figs.

The occurrence of ground water is described for the 11 principal groundwater areas of central and southern Arizona: Duncan, Safford, San Simon, upper San Pedro, lower San Pedro, upper Santa Cruz, lower Santa Cruz, Salt River valley, Rainbow Valley-Waterman Wash, Gila Bend, and WelltonMohawk. Data are presented also for several areas not in the Gila River system, including the Ranegras plain and the Willcox and Douglas basins. Ground water occurs primarily in alluvial fill deposited in structural troughs between mountain ranges. Recharge is mainly from infiltration of runoff along the mountain fronts and seepage from irrigation water. The water quality is generally suitable for irrigation but the problem of salt balance is becoming important. The report contains also a general description of ground-water conditions in the area as a whole, a section on problems relating to use of ground water, and a glossary of ground-water and geologic terms.

Data given for the various areas generally include well records, well logs, chemical analyses, and small-scale areal geologic maps.

\section{Hamilton, Daniel Kirk}

1948. Some solution features of the limestone near Lexington, Kentucky: Econ. Geology, v. 43, no. 1, p. 39-52, figs. 1-12.

No appreciable quantity of ground water is transmitted through interstitial openings in the limestones. Rather, ground-water movement is restricted to openings along joint and bedding planes. Solution along these planes has been effective only to a limited depth below land surface; the depth of solution is greater below stream valleys. Undeground drainage systems show a definite alinement along two sets of joints.

1950. Areas and principles of ground-water occurrence in the Inner Bluegrass Region, Kentucky: Ky. Geol. Survey Ser. 9, Bull. 5, 68 p., 15 pls., 13 figs., 15 maps.

Only Ordovician rocks are found in the area. Limestone is dominant but shaly zones and bentonite beds are important hydrologically. The ground mass of even the most coarsely crystalline limestones is almost impermeable; thus, water occurs and moves in joints and faults and, to a lesser extent, along bedding planes. The base of the zone of solution lies well below the water 
table and shows a configuration roughly similar to the land surface. Beneath valleys solution has been most active, indicating greater circulation of water under topographic lows. Below 90 or $100 \mathrm{ft}$, any water found is usually salty and sulfurous.

The Inner Bluegrass Region covers 1,041 sq mi in Bourbon, Fayette, Jessamine, and Scott Counties. For each of these counties, maps give the location of wells, ground-water areas, geologic structure (with contours drawn on the base of the Eden formation), and areal geology (scale 1:125,000).

Hansen, G. H. See Thomas, H. E., 52c.

\section{Harder, Alfred $\mathrm{H}$.}

1954. (and Drescher, W. J.). Ground-water conditions in southwestern Langlade County, Wisconsin: U. S. Geol. Survey Water-Supply Paper 1294,39 p., 1 pl., 12 figs.

Glacial outwash deposits of sand and gravel compose the principal aquifer. The underlying bedrock of Precambrian age contains little or no water. Movement of ground water is generally southward and locally toward streams. Fluctuations of water levels in wells show a close correlation with seasonal precipitation and with average precipitation over a period of years. Pumping tests made at the city of Antigo's well field gave a coefficient of transmissibility of $62,000 \mathrm{gpd}$ per foot and a coefficient of storage of 0.15 for the outwash deposits, indicating a moderately productive aquifer. It is estimated that recharge to a 90-sq-mi area of the Antigo flats averages about 30,000 acre-ft per year. Of the 1,100 acre-ft pumped from wells in 1948, 69 percent was for municipal supply, 26 percent for rural supply, and 5 percent for irrigation. There has been no substantial decline of water levels in the area as a whole.

Data for the 875 -sq-mi area include 142 well records, 29 well $\operatorname{logs}$, a waterlevel map (for October 1948), and topographic and geologic maps (scale about 1:380,000).

\section{Harshbarger, John W.}

1953. (and Repenning, C. A., and Callahan, J. T.). The Navajo Country, Arizona-Utah-New Mexico, in Subsurface facilities of water management and patterns of supply-type area studies: U. S. Cong., House Comm. Interior and Insular Affairs, Phys. and Econ. Found. Nat. Res., v. 4, chap. 7, p. 105-129, 14 figs.

The Navajo Country is subdivided into eight physiographic areas, each with its own hydrologic characteristics. The rocks of the region include sandstone, mudstone, claystone, and limestone. The sandstone and limestone, by gross volume about 30 percent of all, are found in seven aquifers that are hydraulically separate one from the other: 1) Mesaverde group, 2) Dakota sandstone and upper part of Morrison formation, 3) Cow Springs and Entrada sandstones, 4) Navajo sandstone, 5) Wingate sandstone, 6) Shinarump conglomerate, and 7) DeChelly sandstone member of the Cutler formation.

Information on the Navajo Country is meager and all phases of the hydrologic cycle need to be studied. To obtain optimum service from the little water that falls on the area, it is suggested that runoff be intercepted and stored, and that weeds be replaced by productive forage.

1954. (and Repenning, C. A.). Water resources of the Chuska Mountains area, Navajo Indian Reservation, Apache County, Arizona, and 
San Juan County, New Mexico, with a section on quality of water by

J. L. Hatchett: U. S. Geol. Survey Circ. 308, 16 p., 2 pls., 1 fig.

The stratigraphy and water-bearing character of each rock formation in the area, which contains rocks of Permian, Triassic, Jurassic, Cretaceous, and Tertiary age, are described. The occurrence and chemical quality of ground water, depth to water, and expected yield of wells are discussed for the chief aquifers in the area. The presence of perennial streams along the western escarpment of the mountains is explained as the result of groundwater discharge from the Tertiary Chuska sandstone, which is situated near the top of the mountain block. Measurements have been made of the stream discharge and the fluctuation over several years. Sufficient water will be available for the operation of proposed sawmills and manganese mills if pumpage from ground water is supplemented by surface water diverted into storage reservoirs.

Hastings, Warren W. See also George, W. O., 51, 52a; Sundstrom, R. W., $48 \mathrm{a}$.

1949. Quality of water, in Water resources and hydrology of southeastern Alabama: Ala. Geol. Survey Special Rept. 20, p. 238-264.

The quality of ground water is shown by chemical analyses of samples from 135 wells ranging in depth from 20 to $1,000 \mathrm{ft}$. Water in the Cretaceous formations is, in general, soft and low in mineral content, but some of the water from the Tuscalossa formation contains much iron. Water from wells in the central part of the area in the Providence, Ripley, and Cusseta formations is generally high in dissolved solids, consisting mainly of sodium and bicarbonate. Water from wells in younger Tertiary deposits in southeastern Alabama is generally low in mineral content and soft.

Hatchett, James L. See Coates, D. R., 55; Harshbarger, J. W., 54.

Hazen, G. E.

1946. (and Turner, S. F.). Geology and ground-water resources of the upper Pinal Creek area, Arizona: U. S. Geol. Survey dupl. rept., 55 p., 12 pls., 3 figs.

Locally the Gila conglomerate may prove to be a major aquifer.

Data include 60 well records, 1 test-hole $\log , 3$ well $\operatorname{logs}$, and 24 chemical analyses. Maps show water levels and areal geology (scale about 1:58,000).

\section{Heath, Ralph C.}

1951. (and Clark, W. E.). Potential yield of ground water on the Fair Point peninsula, Santa Rosa County, Florida: Fla. Geol. Survey Rept. Inv. 7, p. 1-56, 10 figs.

Fresh water occurs only within a 150 -ft zone beneath the land surface, in an upper and lower aquifer separated by 10 to $20 \mathrm{ft}$ of clay. Most wells draw from the upper aquifer.

Data for the 15-sq-mi area include 103 well records, 5 chemical analyses, numerous chloride determinations, and results of a test of the upper aquifer.

1954a. (and Barraclough, J. T.). Interim report on the ground-water resources of Seminole County, Florida: Fla. Geol. Survey Inf. Circ. 5, 43 p., 11 figs.

The principal aquifer is composed of the Lake City limestone, Avon Park limestone, and limestone of the Ocala group. Artesian flow occurs from wells penetrating the limestone in lowland areas. Recharge to the aquifer 
occurs in Orange and Polk Counties, and possibly in small areas in Seminole County. A comparison of chloride analyses made in 1937 with those made recently shows that there has been little or no change in chloride content of the artesian water in most of the county.

Maps show water levels in the Sanford-Lake Mary area, areas of artesian flow in the county, and chloride content of ground water. Graphs show (1) relation between chloride content and artesian pressure head and (2) relation between static head and yield of flowing 3-inch artesian wells.

1954b. (and Smith, P. C.). Ground-water resources of Pinellas County, Florida: Fla. Geol. Survey Rept. Inv. 12, 139 p., 21 figs.

The chief aquifer is composed of the Tampa and Suwannee limestones. The water is artesian only in the area south of Palm Harbor. Problems of salt-water encroachment became prominent between 1920 and 1930 , when city wells at St. Petersburg began to yield salt water. Encroachment is now a problem in four coastal areas of the county. Ground-water use is about $14 \mathrm{mgd}$. The underground drainage of Lake Tarpon furnishes material for an unusual and interesting section.

Data for the 290-sq-mi area include 677 well records, 10 chemical analyses, and 500 chloride determinations. Maps show water levels, the top of the Tampa limestone, Pleistocene terraces, and Miocene formations (scale about $1: 300,000)$.

Hem, John D. See also Babcock, H. M., 47b; Gatewood, J. S., 50; Halpenny, L. C., 47c, 47a; McDonald, H. R., 47a.

For sections describing chemical quality of water in-

Fort Defiance area, Arizona, see Halpenny, 49.

Gila Bend basin, Arizona, see Babcock, 48a.

Holbrook area, Arizona, see Babcock, 47c.

Mogollon Rim region, Arizona, see Feth, 54b.

Paradise Valley, Arizona, see McDonald, $47 \mathrm{~b}$.

San Simon basin, Arizona, see Cushman, R. L., 47.

Willcox basin, Arizona, see Jones, R. S., 47.

1950. Geochemistry of ground water: Econ. Geology, v. 45, no. 1, p. 7281.

A review of current and past geochemical studies, their applications to ground-water hydrology, and suggestions for lines of future research.

Hendricks, E. L.

1952. (and Goodwin, M. H., Jr.). Water-level fluctuations in limestone sinks in southwestern Georgia, with particular reference to breeding places of Anopheles quadrimaculatus Say: U. S. Geol. Survey WaterSupply Paper 1110-E, p. 157-246, pl. 8, figs. 20-40.

Hydrologic characteristics of ponds determine the length of time they hold water, influence the species and density of plants that become established, and hence affect mosquito production. Study records for 13 ponds in the area made by analytical, statistical, and graphical methods indicates to what extent the various factors are effective. Precipitation and evapotranspiration appear to be the two most important factors affecing pond levels in the region studied. Significant effects of ground water are confined to relatively short periods of extremely high water-table levels. Brief botanical descriptions of the ponds are included.

1954. Some notes on the relation of groud-water levels to pond levels in 
limestone sinks of southwestern Georgia: Am. Geophys. Union Trans., v. 35, no. 5, p. 796-804, 8 figs.

Some ponds have highly impermeable beds and are virtually unaffected by water-table levels; in others where beds are permeable or water levels are above the rim of the impervious materials, interchange of water occurs.

Hendrickson, Gerth E. See also Foley, F. C., 47; Griggs, R. L., 51.

1952. (and Jones, R. S.). Geology and ground-water resources of Eddy County, New Mexico: N. Mex. Bur. Mines and Min. Res. Ground-

Water Rept. 3, 169 p., 6 pls., 11 figs.

Aquifers are limestone, sandstone, siltstone, and gypsum of Permian and Triassic age, and sand, silt, gravel, and conglomerate of Tertiary and Quaternary age. Ground water is used for all public and domestic requirements, most of the stock water, and much of the irrigation water in the county. Some also is used for potash refining. In the Guadalupe Mountains the chief problem is to find water at moderate depth. Dry holes have been drilled to depths of more than 1,000 ft. In the Carlsbad area, the chloride content of ground water increased between 1943 and 1950. In the Roswell basin, where the ground water is fully developed, the chief problem is to prevent waste or overuse of water. Between the Guadalupe Mountains and the Pecos River, ground-water moving through gypsiferous rocks has poor quality. East of the Pecos River the chief problem is to find water of good quality, as the quantity available is generally sufficient and depths to water are not great.

Data for the 4,163-sq-mi county include 456 well and 16 spring records, 7 well logs, and 99 chemical analyses. Maps show general direction of groundwater flow, ground-water areas, and areal geology (scale about 1:250,000).

Herpers, Henry

1951. (and Barksdale, H. C.). Preliminary report on the geology and ground-water supply of the Newark area, New Jersey: N. J. Div.

Water Policy and Supply Special Rept. 10, 52 p., 5 figs.

Marked lowering of the water table in the eastern part of the area has been accompanied by salt-water encroachment. Ground-water pumpage is about $20 \mathrm{mgd}$. The material filling a buried valley is important locally as an aquifer.

Data include 4 well logs. Maps show chloride content and bedrock surface (scale about $1: 96,000$ ).

Herrick, Eugene H. See Conover, C. S., 55.

Herrick, Stephen M. See also Carter, R. W., 51.

1946. Ground water for irrigation in Georgia: Agr. Eng., v. 27, no. 11, p. 521-522, 2 figs.

Reviews geologic conditions, available ground-water supplies, quality of water, and requirements of supplemental irrigation in Georgia.

1949. (and LeGrand, H. E.). Geology and ground-water resources of the Atlanta area, Georgia: Ga. Geol. Survey Bull. 55, 124 p., 2 pls., 9 figs.

Ground water is obtained from crevices and zones of weathering in crystalline rocks, which include granite, gneiss, and schist. A description of geology and ground-water occurrence is given for each of 7 counties: Clayton, Cobb, DeKalb, Douglas, Fulton, Gwinnett, and Rockdale.

Data for the 2,055-sq-mi area include 492 well records, 14 spring records, 
and 61 chemical analyses. A map showing bedrock geology is adapted from a 1939 geologic map of Georgia.

Hewitt, F. A. See also Baker, R. C., 48.

1949. (and Baker, R. C., and Billingsley, G. A.). Ground-water resources of Ashley County, Arkansas: Ark. Univ. Bur. Research, Research Ser., no. 16, 35 p., 6 figs.

Chief aquifers are the Cockfield formation and Quaternary sand. Sparta sand is as yet virtually unexplored as an aquifer. Pumpage in the county was $21 \mathrm{mgd}$ in 1947.

Data for the 933-sq-mi county include 54 well records, 11 well logs, and 25 chemical analyses. Illustrations include 2 geologic cross sections and a map showing the base of the Sparta sand.

\section{Hollander, J. Theodore}

1954. Possible flow of water between Rito Resumidero and Poleo Canyon Springs, Rio Arriba County, New Mexico: N. Mex. State Engineer Tech. Rept. 2, 18 p., 2 figs.

Geologic evidence strongly suggests a hydrologic continuity between the sinkhole on Rito Resumidero and Poleo Canyon Spring. Tracer tests with fluorescein and sodium chloride prove that at least some of the water from the sinkhole discharges at the spring. Data are not adequate to estimate the proportion that does so discharge.

Holmberg, Glen D. See Mundorff, M. J., 55.

Holmes, Clifford N. See Jones, P. H., $47 \mathrm{~b}$.

Hood, J. W. See also Conover, C. S., 55; Sundstrom, R. W., 52b.

1951. (and Scalapino, R. A.). Summary of the development of ground water for irrigation in the Lobo Flats area, Culberson and Jeff Davis Counties, Texas: Tex. Board Water Engineers Bull. 5102, 25 p., 2 pls., 1 fig.

Describes the general ground-water conditions in the 50-sq-mi area and summarizes the development of ground water through 1950. Data include 91 well records, 36 well $\operatorname{logs}$, and 16 comprehensive and 13 partial chemical analyses.

1952. (and Knowles, D. B.). Summary of ground-water development in the Pecos area, Reeves and Ward Counties, Texas, 1947-51: Tex. Board Water Engineers Bull. 5202, 11 p., 6 figs.

Maps show changes in water level for three different periods and water levels in February 1951.

Hopkins, David M.

1955. (and Karlstrom, Thor N. V., and others). Permafrost and ground water in Alaska: U. S. Geol. Survey Prof. Paper 264-F, p. 109-146, pls. 30-44, figs. 5-11.

The distribution of ground water in Alaska affects and is affected by the distribution of permafrost. Present knowledge of permafrost and groundwater conditions is summarized for the following representative areas of Alaska: the Arctic slope and northern Seward Peninsula in the continuouspermafrost zone; southern Seward Peninsula, the Yukon Flats, the middle Tanana Valley, and the upper Kuskokwim Valley in the discontinuouspermafrost zone; the Bristol Bay region in the sporadic-permafrost zone; and 
the Kenai lowland in the permafrost-free zone. The application and limitations of aerial-photograph interpretation in permafrost studies also are discussed.

\section{Howard, James W., Jr.}

1954. Reconnaissance of ground-water conditions in Curry County, New Mexico: N. Mex. State Engineer Tech. Rept. 1, 35 p., 1 fig.

Ground water occurs principally in the Ogallala formation. Pumpage from 250 wells is used to irrigate about 40,000 acres.

Data for the 1,403-sq-mi county include 150 well records, 11 well $\operatorname{logs}$, and 27 chemical analyses.

Hoy, Nevin D. See also Parker, G. G., 55d.

1952. (and Schroeder, M. C.). Age of subsurface "Tamiami" formation near Miami, Florida: Jour. Geology, v. 60, no. 3, p. 283-286, 2 figs.

A major part of the highly permeable rocks heretofore assigned to the Tamiami formation are not Pliocene in age but Pleistocene, equivalent in part at least to the Fort Thompson formation. The name Tamiami formation should be restricted to the basal portion, below the lowest bed deposited in fresh water. The major part of the aquifer is considered to be a highly permeable and greatly thickened southward extension of the Fort Thompson formation. A cross section shows the geology in Dade County.

Hughes, L. S. See Hale, W. E., 54.

Irelan, Burdge. See Follett, C. R., 49; Scalapino, R. A., 49.

Ivey, John B. See Robinson, W. H., 53.

Jacob, Charles E. See also Cooper, H. H., Jr., 46.

1946a. Notes on Darcy's law and permeability: Am. Geophys. Union Trans., v. 27, no. 2, p. 265-273.

The historical development of the permeability concept is reviewed, the physical quantities involved in flow of perfect liquids through permeable media are discussed, and the numerical values of flow parameters are compared.

1946b. Radial flow in a leaky artesian aquifer, with a discussion by Don

Kirkham: Am. Geophys. Union Trans., v. 27, no. 2, p. 198-208.

Vertical leakage in an artesian system is theoretically proportional to drawdown. The theory can be used to calculate vertical leakage and predict drawdown.

1946c. (and others). Report of the (Am. Geophys. Union) Subcommittee on Permeability: Am. Geophys. Union Trans., v. 27, no. 2, p. 245-256.

Discussions are given of a questionnaire in which it was asked: (1) Should the coefficient of permeability depend only on the structure of the material? (2) Should a name be coined for expressing the combined properties of the material and fluid? (3) What are the parameters that relate only to the structure of the material?

1947. Drawdown test to determine effective radius of artesian well; with discussion by N. S. Boulton, Carl Rohwer, R. M. Leggette, M. R. Lewis, and C. E. Jacob: Am. Soc. Civil Engineers Trans., v. 112, paper 2321, p. 1047-1070, 8 figs.

Specific capacity of a well is shown to decrease with both time and dis- 
charge. A multiple-step drawdown test is outlined to permit determination of "well loss" and "effective radius" of a well. A graphical procedure gives the permeability and compressibility of a bed. From these several factors, the pumping level at any time for any given discharge can be predicted.

1952. (and Lohman, S. W.). Nonsteady flow to a well of constant drawdown in an extensive aquifer: Am. Geophys. Union Trans., v. 33, no. 4 , p. 559-569, 8 figs.

A mathematical theory is given for the discharge of a well of constant drawdown, discharging as by natural flow from an effectively infinite aquifer of uniform transmissibility and uniform compressibility. Two graphical methods are outlined for determining the coefficients of storage and transmissibility from variations in the rate of discharge of wells flowing at constant drawdown. The procedure of the tests is outlined, and the ink-well mercury gage used to measure the artesian head is described.

\section{Jacobson, Clyone Lynn}

1949. (and Reed, E. W.). Ground-water supplies in the Oklahoma City area, Oklahoma: Okla. Geol. Survey Min. Rept. 20, 21 p., 2 figs.

Alluvium of the North Canadian River at the west side of Oklahoma City could yield $10 \mathrm{mgd}$ for a time, but the reserves would be rather rapidly exhausted.

Data include a map of terrace deposits near Bethany, pumpage figures, and 16 well logs.

Jameson, C. H. See Maxey, G. B., 46, 48.

Jeffords, Russell M. See also Allen, W. B., 48b.

1946. (and Nace, R. L.). Ground-water conditions at Charleston, West Virginia: Am. Water Works Assoc., Jour., v. 38, no. 11, pt. 1, p. 13091314, 4 figs.

Ground-water pumpage is about $1.46 \mathrm{mgd}$ in Charleston and $0.9 \mathrm{mgd}$ in the surrounding industrial area. Local overdevelopment in Charleston has occurred in bedrock aquifers but not, as yet, in the alluvial deposits.

1948a. Graphic representation of oil-field brines in Kansas: Kans. Geol. Survey Bull. 76, pt. 1, p. 1-12, 6 figs.

The density of Kansas oil-field brines is shown graphically to be related to the sodium, calcium, magnesium, and dissolved solids. These relations seem essentially similar regardless of depth, age, or composition of the producing formation. A comparison of the density-concentration relations of the Kansas brines with those from the Appalachian area indicates that the Kansas brines differ significantly in percentage of dissolved constituents.

1948b. (and Allen, W. B.). Ground-water conditions in the vicinity of Mashapaug Pond, Providence, Rhode Island: New England Water Works Assoc. Jour., v. 52, no. 1, p. 38-61, 8 figs.; reprinted as R. I. Indus. Comm. Sci. Contr. 1.

The Gorham well field near Mashapaug Pond in southwestern Providence is located along the eastern edge of a large buried valley. Data are given for an aquifer test of glacial outwash in the valley.

1950. The ground-water resources of Montgomery County, New York: N. Y. Water Power and Control Comm. Bull. GW-23, 63 p., 2 pls., 11 figs. 
The chief water-bearing formations comprise the Little Falls dolomite, the Canajoharie and Utica shales, and unconsolidated deposits of glacial drift and gravel. Ground-water use does not exceed the annual recharge in the area as a whole, but heavily pumped areas in Canajoharie and Amsterdam may be approaching a critical condition.

Data for the 400-sq-mi county include 365 well and spring records, 8 well logs, and 35 chemical analyses. Geologic maps of surficial deposits and bedrock are adapted from existing sources.

1952. Pumping tests on wells in Iowa: Iowa Acad. Sci. Proc., v. 59, p. 266-287, 12 figs.

Reviews briefly the interpretation of aquifer-test data.

Jochens, E. R. See Tychsen, P. C., 55.

Johnson, A. H. See Lusczynski, N. J., 51.

Johnson, Arnold I.

1955. Selected references on permeability, in Symposium on permeability of soils: Am. Soc. Testing Materials, Special Tech. Pub. 163, p. 131136.

The references are grouped under the following headings: flow theory, methods, fluids, porosity, and other factors.

Johnston, H. F.

1949. The cooperative ground-water program in West Virginia: W. Va. Acad Sci. Proc. 1947, v. 19, p. 146-151.

A brief description of the occurrence and quality of ground water in the State. Data include a summary of highest and lowest water levels observed in 21 wells, and chemical analyses of 5 very different waters.

Johnston, Paul M. See Cederstrom, D. J., 53.

Jones, D. S., Jr. See Waite, H. A., 46.

Jones, I. I. See Halpenny, L. C., $47 \mathrm{a}$.

Jones, James R. See Akin, P. D., 52a.

Jones, Paul H. See also Barksdale, H. C., 53; Turcan, A. N., Jr.

1947a. Rice irrigation with ground water in southwestern Louisiana: Rice Jour., v. 50, no. 3, p. 11-14.

Discusses the sources, development, and usage of ground water in the area. Data include a water-level map.

1947b. (and Holmes, C. N.). Ground-water conditions in the Monroe area, Louisiana: La. Dept. Pub. Works. Geol. Bull. 24, 47 p., 5 pls., 5 figs.

The chief aquifers are the Sparta sand, Cockfield formation, terrace deposits, and alluvium. Ground-water can supply about $6 \mathrm{mgd}$ in the area. The quality of water is excellent.

Data for the 216-sq-mi area include 47 well records, 4 test-hole logs, 27 well logs, a water-level map, 3 geologic cross sections, 18 chemical analyses, and particle-size analyses.

1948a. (and Turcan, A. N., Jr.). 1947 ground-water survey: Rice news, v. 15 , no. 1 , p. $3-5,8-10$.

During the 1947 rice-irrigating season, half the rice acreage was flooded by well water, which amounted to 500,000 acre-ft. 
1948b. Ground-water summary: Rice News, v. 15 , no. 12, p. $3,7$.

Review of ground-water investigations in Louisiana.

1951. (and Buford, T. B.). Electric logging applied to ground-water exploration: Geophysics, v. 16, no. 1, p. 115-139, 12 figs.

After briefly describing conventional techniques of electric-log interpretation, methods are described for converting water-resistivity values of electric logs into hypothetical chemical analyses and for determining formation porosity.

1952. Electric-logging methods, principles of interpretation, and applications in ground-water studies: U. S. Geol. Survey dupl. rept.

In ground-water investigations the electric log can be used to determine the chemical quality of ground water in granular aquifers.

1954a. Ground water in the Vermilion River basin, Louisiana: Am. Soc. Civil Engineers Proc., v. 80, Separate 490, 19 p., 12 figs.

The location of sand and gravel in the lower part of the Vermilion River basin favors recharge of its water supply from the river. However, at low river stage, the aquifer is recharged by salty water from the river. Because the aquifer is tapped by more than a thousand rice-irrigation wells, continued salt-water contamination from the Vermilion River threatens the total ground-water supply of the southern part of southwestern Louisiana.

Illustrations include water-level maps and cross sections.

1954b. (and Turcan, A. N., Jr., and Skibitzke, H. E.). Geology and ground-water resources of southwestern Louisiana: La. Geol. Survey Geol. Bull. 30, 285 p., 36 pls., 60 figs.

Vast aquifers of sand and gravel in southwestern Louisiana generally range in thickness from 200 to $600 \mathrm{ft}$, but in south-central Acadia Parish, one massive gravelly aquifer is more than $800 \mathrm{ft}$ thick. The aquifers slope gently gulfward, are overlain by impermeable clay, and are recharged to the north of the rice-farming area. Ground-water withdrawal in the area has been as great as 800,000 acre-ft per yr. Fresh ground water occurs to a maximum depth of $3,100 \mathrm{ft}$. The Le Moyen formation of Recent age and Foley formation of Pliocene age are defined in the report.

Data for the 15,000-sq-mi area include 307 well records, 1 test-hole log, 22 well logs, 69 chemical analyses, numerous particle-size analyses, and aquifer tests of the Chicot aquifer. Methods of locating areas of recharge are discussed, as well as percolation from either above or below through leaky aquicludes. Hydrologic maps show maximum depth of occurrence of fresh ground water, distribution of chloride and hardness, and water levels. Other illustrations include 5 geologic cross sections and maps showing top of Pleistocene, base of Pleistocene, and depth to the Chicot aquifer (most maps at scale of about $1: 1,000,000$ ).

Jones, Robert S. See also Cushman, R. L., 47; Hendrickson, G. E., 52.

1947. (and Cushman, R. L.). Geology and ground-water resources of the Willcox basin, Cochise and Graham Counties, Arizona, with a section on quality of water by J. D. Hem: U. S. Geol. Survey dupl. rept., 35 p., 1 pl., 1 fig.

The Willcox basin has interior drainage into Willcox playa. The basin was formed by downdropping of the valley and uplifting of the surrounding mountains. The chief aquifers are lenses of sand and gravel in alluvial fill. 
Water levels in areas of heavy pumping have declined as much as $25 \mathrm{ft}$ in $36 \mathrm{yrs}$.

Data for the 1,200-sq-mi area include 27 well records, 15 well logs, 11 chemical analyses, and an areal geologic map (scale about 1:40,000). For a more recent report, see Halpenny 52 .

Jones, Suzanne L. See Dennis, P. E., 49a, 50b.

Karlstrom, Thor N. V. See Hopkins, D. M., 55.

Kaser, Paul. See also Van Tuyl, D. W., 48.

1950. Ground-water levels in Ohio, 1948: Ohio Div. Water Bull. 21, 60 p., 32 pls.

Presents data on and interpretation of water-level fluctuations as observed during 1948 in wells scattered through 57 counties. Of the wells observed, 121 were equipped with automatic recorders.

1952. Ground-water levels in Ohio, 1949-50: Ohio Div. Water Bull. 25, 103 p., 147 figs.

Presents data on and interpretations of level fluctuations as observed during 1949-50 in 201 observation wells in 58 counties.

1954. Ground-water levels in Ohio, 1951-52: Ohio Div. Water Bull. 28, 95 p., 132 figs.

Presents data on and interpretations of water-level fluctuations in 205 observation wells in 66 counties.

\section{Kazmann, Raphael G.}

1946. Notes on determining the effective distance to a line of recharge: Am. Geophys. Union Trans., v. 27, no. 6, p. 854-859, 3 figs.

The effective distance to the line of recharge can be determined from two measurable variables: the drawdowns in a single observation well and the duration of pumpage.

1948. River infiltration as a source of ground-water supply: Am. Soc. Civil Eng. Trans., v. 113, paper 2339, p. 404-424, 7 figs.

Describes relation of river stage to well yield and effect of changes in river temperature on well yield, drawdown, and water temperature as observed at the Indiana Ordnance Works near Charlestown, Indiana. Despite infiltration of contaminated river water, pathogenic bacteria were not found in water drawn from the horizontal-collector wells being used, which are immediately adjacent to the river.

\section{Keech, Charles Franklin}

1952. Ground-water resources of the Wood River unit of the lower Platte River basin, Nebraska: U. S. Geol. Survey Circ. 139, 96 p., 3 pls., 9 figs. The Wood River unit, in Buffalo and Hall counties, is an area of nearly flat land in the Platte and Wood River valleys, between the towns of Kearney and Wood River, Nebraska. It is underlain by unconsolidated Quaternary sediments, which in turn rest on partly cemented beds of the Ogallala formation. Abundant supplies of ground water are available at relatively shallow depth and are extensively used. Sustained yields of 300 to more than 1,500 gpm from wells are common. In 1947, 77,600 acre-ft of water was pumped from 1,113 wells to irrigate 51,000 acres. The average decline of the water level from 1931 to 1948 was about $2.6 \mathrm{ft}$; the greatest decline was about $9 \mathrm{ft}$.

Data for the 233-sq-mi area include 1,113 well records, 1 test-hole log, 
2 well logs, a water-level map (for March and September 1948), and a depthto-water map.

1955. Hydrology of Clay County, Nebraska, with special reference to recharge: U. S. Geol. Survey dupl. rept., 10 p., 4 figs.

Recharge from precipitation in Clay County is about 50,000 acre-ft per year. This is about twice the amount pumped for irrigation in 1954 .

A map shows the estimated transmissibility in the saturated deposits of the county.

KendaIl, Kenneth K., Jr. See Babcock, H. M., $48 \mathrm{~b}$.

Kenner, W. E. See Cooper, H. H., Jr., 53.

Kent, Deane $F$.

1950. Techniques used in mine-water problems of the east Tennessee zinc district: U. S. Geol. Survey Circ. 71, 9 p., 1 fig.

Describes a study of ground water as related to mining in cavernous limestone and dolomite in eastern Tennessee. Surface and subsurface mapping indicated the geologic control of underground channels. Rainfall data, when correlated with ground-water volumes and velocities, gave much information as to expected pumping volumes for any period. The use of fluorescein dye for tracing the flow of the water is described, and other methods are discussed briefly.

Klaer, Fred H., Jr. See also Stallman, R. W., 50.

1948. (and Guyton, W. F., and Todd, D. K.). A preliminary list of references pertaining to artificial recharge of ground water in the United States: U. S. Geol. Surve dupl. bibliography, 35 p.

Artificial recharge is the increasing of the natural rate of infiltration into aquifers by acts of man. The bibliography, in addition to giving a rather complete listing of papers on the subject, includes a list of localities in the United States where artificial recharge is being or has been used.

1948b. (and Stallman, R. W.). Ground-water resources of St. Joseph County, Indiana; pt. 1-South Bend area: Ind. Dept. Conserv. Div. Water Res. Bull. 3, 177 p., 6 pls., 10 figs.

Sand and gravel deposits of glacial and alluvial origin are the chief aquifers. Ground-water supplies have been fully developed only in the downtown business section of South Bend.

Data for the 24-sq-mi area include 200 well records, 10 well logs, periodic chemical analyses of water from city supply wells, history of South Bend city well fields, and aquifer tests of glacial and alluvial sand and gravel. Illustrations include 5 geologic cross sections, and maps showing water levels, bedrock surface, and glacial geology (based on a published source). The term area of diversion is defined (p. 69).

1948c. (and Thompson, D. G.). Ground-water resources of the Cincinnati area, Butler and Hamilton Counties, Ohio: U. S. Geol. Survey Water-Supply Paper 999, 168 p., 15 pls., 22 figs.

Describes the occurrence and availability of ground water in the buried glacial valleys in the Cincinnati industrial area. The area includes, in addition to Cincinnati and its environs, the cities of Middletown and Hamilton. The glacial outwash deposits in the buried valleys range in thickness from about $100 \mathrm{ft}$ to nearly $280 \mathrm{ft}$ and during 1939 yielded an average of about 
$76 \mathrm{mgd}$ of water to wells for municipal and industrial use. Ground-water levels in certain parts of the area have declined 90 to $100 \mathrm{ft}$ during the past 58 years, especially in the Mill Creek Valley south of Glendale. In the Middletown and Hamilton areas, although water levels have declined to some extent, additional ground-water supplies can be obtained from properly located wells. The safe yield of the Mill Creek Valley between Glendale and Ivorydale is estimated to be about $13 \mathrm{mgd}$, about equal to the average daily pumpage from wells in 1939. Further development of ground-water supplies in this area probably will cause continued declines in ground-water levels and an eventual falling off in yield. Artificial recharge and other means of increasing the available water supply are discussed.

Data for the 100-sq-mi area include 542 well records, pumpage figures, and 15 chemical analyses.

1949. Ground-water levels in Indiana: Ind. Acad. Sci. Proc., v. 59, p. 236-245, 4 figs.

Ground-water resources of Indiana as a whole are not being depleted and additional ground-water supplies can be developed in many areas.

1950a. Ground-water levels in Indiana: Ind. Acad. Sci. Proc., p. 236-245, 4 figs.

Describes the observation-well program in Indiana. Concludes that, in general, ground-water supplies in the State are not being exhausted, and, moreover, additional ground-water supplies can be developed in many areas.

1950b. Present status of our ground-water supplies in Indiana, in Indiana Water Conservation Conference Proceedings: Ind. Dept. Conserv. Div. Water Res. dupl. rept., p. 8-22, 1 fig.

Reviews briefly the fundamentals of ground-water hydrology, presents a map and description of the ground-water provinces of Indiana, and discusses the quality of water, the utilization of water, and ground-water levels of the State.

Klein, Howard. See also Counts, H. B., 55; Schroeder, M. C., 54a.

1950. (and Baker, R. C., and Billingsley, G. A.). Ground-water resources of Jefferson County, Arkansas: Ark. Univ. Inst. Sci. and Technology Research Ser., no. 19, 44 p., 8 figs.

Total ground-water use in the county is $29 \mathrm{mgd}$. The Sparta sand yields more than $10 \mathrm{mgd}$ and Quaternary deposits yield $18 \mathrm{mgd}$, mainly for rice irrigation. The safe yield of the Sparta sand is considerably in excess of present use, but pumpage from the Quaternary aquifer is roughly twice the rate of recharge.

Data for the 903-sq-mi county include 133 well records, 70 chemical analyses, and results for aquifer-tests of the Sparta sand and Quaternary sand and gravel. A map shows thickness of gravel in the alluvium (scale about 1:500,000).

1954. Ground-water resources of the Naples area, Collier County Florida: Fla. Geol. Survey Rept. Inv. 11, 64 p., 15 figs.

Fresh water is derived from (1) an unconfined aquifer formed by the Pamlico sand, the Anastasia formation, and a portion of the upper part of the Tamiami formation; and (2) a shallow artesian aquifer entirely within the Tamiami formation. The water quality is nearly the same in both aquifers. Salt-water encroachment has occurred in both aquifers near the coast and in 
the southern part of Naples. Water from the deeper, or principal, artesian aquifer in the Ocala and associated limestones contains about $2,000 \mathrm{ppm}$ of chloride.

Data for the 2-sq-mi area include 73 well records, 5 test-hole logs, waterlevel data, 18 chemical analyses, a fossil list, and results of 3 aquifer tests on the shallow artesian aquifer. Illustrations include 5 water-level maps and 2 geologic cross sections.

Klein, Norman H. See Adamson, J. H., Jr., 49b; Van Tuyl, D. W., 51c.

\section{Klug, Mervin L.}

1955. Geology and ground-water resources of the Alexandria area, Rapides Parish. Louisiana: La. Geol. Survey and La. Dept. Public Works, Water Res. Pamph. 3, 23 p., 4 figs.

The chief aquifers are sands of Miocene age. Current withdrawals of $6 \mathrm{mgd}$ could be increased by $4 \mathrm{mgd}$ with proper location and spacing of wells. Relatively large supplies can be obtained from the Recent alluvium and Pleistocene deposits also.

Data include 23 well records, 7 chemical analyses, pumpage figures, and results for aquifer tests of the " $400-"$, " $700-"$, and " $1,000-\mathrm{ft}$ " sands in the Catahoula formation.

Knowles, Doyel B. See also Hood, J. W., 52; Willis, G. W., 53.

1946. Scurry County, Texas, records of wells, drillers' logs, water analyses, and map showing location of wells: Tex Board Water Engineers dupl. rept., 33 p., 2 figs.

Data for the 909-sq-mi county include 177 well records, 43 well logs, 108 chemical analyses, and a geologic map based on the 1937 geologic map of Texas.

1947a. Ground water in northwestern Nolan County, Texas: Tex. Board Water Engineers, dupl. rept., 7 p., 1 fig.

Data include 29 well records, 1 well $\log$, and 18 chemical analyses.

1947b. (and Lang, J. W.). Preliminary report on the geology and groundwater resources of Reeves County, Texas: Tex. Board Water Engineers dupl. rept., 87 p., 2 pls., 1 fig.

The chief aquifer is alluvial sand and gravel in an elongated trough 10 to 15 miles wide extending from the Pecos River north of Pecos southward to the vicinity of Balmorhea.

Data for the 2,600-sq-mi county include 342 well and 16 spring records, 83 well logs, and 195 chemical analyses.

1952. Ground-water resources of Ector County, Texas: Tex. Board Water Engineers Bull. 5210, 112 p., 2 pls., 5 figs.

The chief aquifer is sand of the Trinity group. A buried eastward-trending valley in the northeastern part of the county offers the most promise for development of ground-water supplies.

Data for the 907 -sq-mi county include 419 well records, 188 well logs, and 171 chemical analyses, pumpage figures, and a water-level map.

Koopman, Francis C. See Moulder, E. A., 53.

Kunkel, Fred. See Poland, J. F., 51; Upson, J. E., 55 b. 
Laine, L. L.

1951. (and Schoff, S. L., and Dover, T. B.). Public water supplies in Oklahoma: Okla. Plan. and Res. Board, 112 p.

Gives a summary description of the water supplies of the 364 communities in Oklahoma served by public systems in 1949. Of these, 264 obtained their supply from ground-water sources and in 1949 furnished $34 \mathrm{mgd}$. Aquifers are identified geologically. Representative chemical analyses are given.

Laird, L. B. See Stramel, G. J., 54; Wisler, C. O., 52.

Laird, Wilson M. See also Byers, A. C., 46.

1948. (and Akin, P. D.). Ground water in the Zeeland area, North Dakota: U. S. Geol. Survey N. Dak. Ground-Water Studies 12, 38 p., 8 figs.

A shallow aquifer yielding water of excellent quality is present about $2 \mathrm{mi}$ west of Zeeland. However, an aquifer test indicates that the aquifer is of limited extent and that its perennial yield is insufficient for municipal or other large-scale use at Zeeland.

Data for the 40-sq-mi area include 62 well records, 16 test-hole logs, 2 chemical analyses, 3 cross sections, a water-level map, a depth-to-water map, and aquifer-test data for a glaciofluvial aquifer near Zeeland.

LaMoreaux, Philip E. See also Toulmin, L. D., Jr., 51, 53.

1946a. Geology of the Coastal Plain of east-central Georgia: Ga. Dept. Mines, Mining, and Geology Bull. 50, pt. 1, 26 p., 1 pl., 8 figs.

For a later, more comprehensive report, see LaMoreaux $46 \mathrm{~b}$.

1946b. Geology and ground-water resources of the Coastal Plain of eastcentral Georgia: Ga. Geol. Survey Bull. 52, 173 p., 2 pls., 21 figs.

The chief aquifer is the thick sand and gravel of the Tuscaloosa formation. Yields range from a few gallons per minute to as much as $800 \mathrm{gpm}$.

Data for the 1,881-sq-mi area include 401 well records, well logs, $12 \mathrm{com}$ prehensive and 69 partial chemical analyses, measured geologic sections, and an areal geologic map (scale about 1:140,000).

1947. Fluoride in the ground water of the Coastal Plain of Alabama: Ala. Acad. Sci. Jour., v. 19, p. 13-16.

Water from the Eutaw, Ripley, and Nanafalia formations of the Coastal Plain contains the most fluoride of any of the aquifers in the State.

1948a. The occurrence of ground water in Alabama: Ala. Water and Sewage Assoc. Official Bull., p. 1-18, 5 figs.

Reviews the history of ground-water investigations in Alabama, outlines the geology of the State, and sketches the occurrence of ground water.

1948b. Fluoride in the ground water of the Tertiary area of Alabama: Ala. Geol. Survey Bull. 59, 77 p., 1 pl.

Water from the glauconite sands in the Eutaw, Ripley, Nanafalia, and Lisbon formations of the Coastal Plain of Alabama contains larger amounts of fluoride than does that from other formations. Fluoride-bearing water is correlated with the occurrence of volcanic material, phosphate minerals, bentonite, pyrite, lignite, and glauconite. In areas where water of high fluoride content occurs, fluoride-free water generally can be obtained from either an overlying or an underlying formation. 
1948c. (and Lanphere, C. R.). Ground water used for public and rural supplies in Alabama: Ala. Acad. Sei. Jour., v. 20, p. 40-41.

The Coastal Plain area has the most favorable geologic conditions in the State for development of ground water. The Paleozoic area is next but the development of ground water depends on local geologic conditions such as solution openings and fractures. The Piedmont area is the least favorable for large yields, most wells yielding less than $10 \mathrm{gpm}$.

1949a. Ground-water geology of Tennessee Valley area in Alabama, with reference to vertical drainage: Ala. Geol. Survey Circ. 18, 13 p., 2 figs.

Intermittent ponds can be drained into wells if the water table is below pond level for a sufficient part of the year. Contamination of ground-water supplies can result from such drainage.

1949b. Ground water in southeastern Alabama, in Water resources and hydrology of southeastern Alabama: Ala. Geol. Survey Special Rept. 20, p. 200-237, pl. 1, figs. 45-46.

Ground water is used by 47 cities and towns as the source of 98 percent of the public water supply in the area.

Data include 222 well records, descriptions of public water supplies, and descriptions of geologic formations in the area. For description of water quality in the area, see Hastings 49.

1950a. Fluoride in ground water of Alabama: Min. Eng., v. 187, no. 8, p. 886-888, 1 fig.

Coastal Plain sediments yield water containing as much as $6.0 \mathrm{ppm}$ of fluoride. Paleozoic and older rocks yield water generally containing less than $0.5 \mathrm{ppm}$ of fluoride.

1950b. Nitrate in ground water of the Coastal Plain of Alabama: Ala. Acad. Sci. Jour., v. 22, p. 86-88.

High nitrate in well waters in nearly every case could be explained by contamination from surface seepage. Analyses of water from flowing artesian wells generally showed less than $0.3 \mathrm{ppm}$ of nitrate, and none more than $3 \mathrm{ppm}$.

1950c. (and Swindel, G. W., Jr., and Lanphere, C. R.). Ground-water resources of the Huntsville area, Alabama: Ala. Geol. Survey Bull. 62, 82 p., 12 pls., 6 figs.

The chief aquifers are Mississippian limestones. Additional ground-water supplies can be obtained by development of some of the larger springs and from properly located wells.

Data for the 220-sq-mi area include 103 well and spring records and 3 comprehensive and 10 partial chemical analyses. The geologic map is modified from the 1926 geologic map of Alabama.

1953a. Water-level fluctuations in observation wells in Alabama caused by the Kamchatka earthquake on November 4, 1952: Ala. Acad. Sci. Jour., v. 25, p. 37-39, 1 fig.

Data for 5 wells and hydrographs for 4 wells at Huntsville and Guin, Alabama, show the recorded effect of the earthquake.

1953b. Ground water-A vital Alabama resource: Ala. Water and Sewage Assoc. Bull., v. 7, no. 4, p. 8-18, 3 figs.

Reviews ground-water development and investigations in Alabama. Outlines provisions in a proposed bill for a State ground-water law. Illustrations 
include a generalized block diagram of ground-water occurrence in the Coastal Plain and maps showing areas of artesian flow, areas of declining artesian head, and areas of ground-water investigations.

Lane, C. W.

1953. (and Cooper, J. B.). Determination of altitude with the aneroid barometer: Iowa Acad. Sci. Proc., v. 60, p. 393-398.

Field procedures for altimeter traverses are reviewed. Procedures for making temperature and pressure corrections are outlined. Altitudes so determined should have an accuracy within $5 \mathrm{ft}$.

Lang, Joseph W. See also Knowles, D. B., $47 \mathrm{~b}$.

1946. Ground-water resources of the Houston district, Texas; progress report for 1946, with a section on results of pumping tests at new Southwest pumping plant by J. W. Lang and R. W. Sundstrom: Tex. Board Water Engineers dupl. rept., 34 p., 14 figs.

Pumpage in the Houston district averaged $119 \mathrm{mgd}$ in 1946 . Water levels declined generally except in the Bammel gas field, where a leaky gas well caused a temporary water-level rise of $61 \mathrm{ft}$. Results of aquifer tests on Quaternary sands are used to predict drawdowns to be expected at several pumping rates.

Data include water-level measurements and water-level maps for January of the years 1941-46 inclusive.

1950. (and Winslow, A. G.). Geology and ground-water resources of the Houston district, Texas: Tex. Board Water Engineers Bull. 5001, 55 p., 3 pls., 15 figs.

Potable water in some parts of the Houston district extends to greater depths than previously had been supposed possible. Data on pumpage and decline of artesian pressures are given and discussed for the period 1930-49. Briefly describes stratigraphy and water-bearing properties of chief aquifers.

Data for the 1,800-sq-mi area include results of 14 aquifer tests, periodic water-level measurements, periodic chloride determinations, 46 chemical analyses, and 3 cross sections correlating facsimilies of electric logs.

1953. Ground water in the Trinity group in the San Antonio area, Texas: Tex. Board Water Engineers dupl. rept., 5 p., 1 fig.

The sands of the Trinity group in the San Antonio area of Bexar County are relatively poor aquifers. They contain considerable shale and are tightly cemented. Specific capacities are on the order of 3 or $4 \mathrm{gpm}$ per $\mathrm{ft}$ of drawdown. The water from the sands of the Trinity is inferior in quality to that from the Edwards limestone.

1954. Ground-water resources of the San Antonio area, Texas; a progress report of current studies: Tex. Board Water Engineers Bull. 5412, 30 p., 6 figs.

Describes the sources of recharge to the Edwards limestone, gives an estimate of the perennial yield of the aquifer, and contains a water-level map.

1955a. Ground-water supplies for Mississippi industry: Miss. State College Indus. Water Conf. Proc., p. 4-17.

Although the ground-water supply in Mississippi is very large, too little is known of the occurrence, chemical quality, temperature, and volume available by areas and localities.

1955b. Ground water, in Water for the future in Mississippi: Miss. Water 
Res. Policy Comm. report to the 1956 Mississippi Legislature, p. 1223, figs. 7-11.

Reviews ground-water occurrence and problems in Mississippi. Illustrations include 2 geologic cross sections and a map of the important aquifers in the State (scale about 1:2,500,000).

Lang, Solomon M. See Barksdale, H. C., 55a; Remson, Irwin, 55c.

Langbein, Walter B.

1949. Computing soil temperatures: Am. Geophys. Union Trans., v. 30, no. 4 , p. 543-547, 4 figs.

Develops a method for computing temperatures at a point in a soil expressed as a weighted function of antecedent temperatures at the surface. An analogy is made with the unit hydrograph.

Lanphere, C. R. See also LaMoreaux, P. E., 48c, 50c; Toulmin, L. D., Jr., 51.

1955. Geologic source and chemical quality of public ground-water supplies in western Tennessee: Tenn. Div. Geology Rept. Inv. 1, 69 p., 2 figs.

The area covers $10,500 \mathrm{sq} \mathrm{mi} \mathrm{west} \mathrm{of} \mathrm{the} \mathrm{northward-flowing} \mathrm{section} \mathrm{of} \mathrm{the}$ Tennessee River and lying in the upper Mississippi Embayment. Sands of the Claiborne and Wilcox groups and the Ripley formation are the chief aquifers developed for municipal supplies. Palezoic limestone and chert, sands of the Eutaw formation, and Pliocene and Pleistocene terrace deposits also are used.

Data include description of 62 municipal water supplies and 105 chemical analyses.

LaRoque, George Albert, Jr.

1950. (and Upson, J. E., Worts, G. F., Jr., and Porter, L., Jr.). Wells and water levels in principal ground-water basins in Santa Barbara County, California: U. S. Geol. Survey Water-Supply Paper 1068, 459 p., 7 pls., 8 figs.

This report presents, in tabular form, data on water wells and water levels in observation wells in seven agricultural districts of Santa Barbara County, California. Part 1 contains the data on the Carpinteria, Goleta, and lower and middle Santa Ynez Valleys in the southern part of the county; part 2 contains the data on the San Antonio, Santa Maria, and Cuyama Valleys in the northern part of the county. Maps show locations of wells in these valleys.

1954a. Section on ground-water resources, in Townsend, R. C., Geology of Noonan quadrangle, North Dakota: U. S. Geol. Survey Geol. Quadrangle Map 44.

Usable quantities of ground water may be obtained from lignite and sandstone of the Fort Union formation and from sand and gravel of the glacial deposits.

1954b. Section on ground-water resources in Townsend, R. C., Geology of Crosby quadrangle, North Dakota: U. S. Geol. Survey Geol. Quadrangle Map 46.

Usable quantities of water may be developed from the lignite and sandstone beds of the Fort Union formation and from the glacial sand and gravel deposits. 
1954c. Section on ground-water resources, in Townsend, R. C., Geology of Portal quadrangle, North Dakota: U. S. Geol. Survey Geol. Quadrangle Map 47.

Usable quantities of water may be developed from lignite and sandstones of the Fort Union formation, from sand and gravel lenses in the Max moraine, from kames and eskers, and from glacial channel deposits of sand and gravel.

\section{Latta, Bruce F.}

1948a. Ground-water supplies at Hays, Victoria, Walker, Gorham, and Russell, Kansas: Kans. Geol. Survey Bull. 76, pt. 6, p. 121-196, 8 figs. A reconnaissance report to provide a basis for judging whether groundwater supplies are adequate for anticipated needs or whether surface water from the Cedar Bluff Reservoir will be needed. Report contains 94 well logs, 1 chemical analysis, and a geologic map of the Hays area (scale about 1:77,000).

1948b. Geology and ground-water resources of Kiowa County, Kansas: Kans. Geol. Survey Bull. 65, 151 p., 11 pls., 10 figs.

Chief aquifers are sand and gravel beds in the Meade and Ogallala formations throughout the county and alluvium in the larger stream valleys. Small water supplies in the southeastern part of the county are obtained from the Cheyenne sandstone. Depth to water ranges from less than $10 \mathrm{ft}$ in parts of the sandhills area to $185 \mathrm{ft}$ on the uplands south of Mullinville.

Basic data for the 720-sq-mi county include 122 well records, 19 test-hole $\operatorname{logs}, 7$ well logs, 18 measured geologic sections, particle-size analyses, and 32 chemical analyses. Illustrations include a water-level map, contour maps on the top of the Cheyenne sandstone and the pre-Ogallala surface, 5 geologic cross sections, and an areal geologic map (scale about 1:130,000).

1949. Ground-water conditions in the Smoky Hill Valley in Saline, Dickinson, and Geary Counties, Kansas: Kans. Geol. Survey Bull. 84, 152 p., 6 pl., 13 figs.

Relatively impermeable Permian and Cretaceous strata dip gently to the west but are beveled by an eastward-sloping erosion plain. The Smoky Hill River and its tributaries have cut below this plain and flow in wide valleys partly filled with unconsolidated alluvium of Quaternary age. The alluvium is thick in many places and is the most important source of water in the area.

Data for the 200-sq-mi area include 98 well records, 93 test-hole logs, 53 well $\operatorname{logs}$, water-level data, and 63 chemical analyses. The report includes also 14 geologic cross sections and a geologic map (scale about 1:130,000).

1950. Geology and ground-water resoures of Barton and Stafford Counties, Kansas: Kans. Geol. Survey Bull. 88, 228 p., 11 pls., 18 figs.

Chief aquifers are the Meade formation and Dakota sandstone. Locally the water in both is highly mineralized.

Data for the 1,686-sq-mi area include 371 well records, 106 test-hole logs, 24 well $\operatorname{logs}$, and 100 chemical analyses. Hydrologic maps show water levels and saturated thickness of the post-Cretaceous deposits. Illustrations include 11 geologic cross sections and maps of the bedrock geology, bedrock surface, and areal geology about $(1: 130,000)$.

Leggatt, E. R. See also Barnes, J. R., 49.

1951. Development of wells for irrigation and fluctuation of water levels 
in the High Plains of Texas to January 1951: Tex. Board Water Engineers Bull. 5104, 7 p., 18 figs.

During 1950, about $1,600,000$ acre-ft of water was pumped from 14,500 , irrigation wells in the southern High Plains. The pumping caused an average water-level decline of $1.3 \mathrm{ft}$.

Data include periodic water-level measurements, numerous hydrographs, and 2 maps of water-level decline.

1952. Geology and ground-water resources of Lynn County, Texas: Tex. Board Water Engineers Bull. 5207, 71 p., 2 pls., 7 figs.

The chief aquifer is the Ogallala formation. Future development of irrigation supplies will be limited to the northern part of the county and to a small area east of Tahoka. Thinning of the aquifer and mineralized water preclude large-scale development in the remainder of the county.

Data for the 900 -sq-mi county include 413 well records, 64 well logs, 81 chemcal analyses, pumpage figures, periodic water-level measurements, and 2 cross sections.

1954a. Summary of ground-water development in the southern High Plains, Texas: Tex. Board Water Engineers Bull. 5402, 21 p., 11 figs.

Gives pumpage data and summarizes the effects of ground-water development on pumping levels and well discharges. Maps show water-level decline for the periods March 1938 to January 1953 and February 1952 to January 1953.

1954b. Ground-water development in the southern High Plains of Texas, 1953: Tex. Board Water Engineers Bull. 5410, 7 p., 2 figs.

Data are given regarding ground-water withdrawals. A map shows waterlevel decline from January 1953 to January 1954.

Leggette, R. M. See Taylor, G. H., 49.

LeGrand, Harry E. See also Herrick, S. M., 49; Mundorff, M. J., 49.

1949. Sheet structure, a major factor in the occurrence of ground water in the granites of Georgia: Econ. Geology, v. 44, no. 2, p. 110-118, 5 figs.

Major parting planes resulting from sheeting are usually subparallel to the rock surface on hills and in valleys and consequently control the circulation of ground water. Imperfect shallow pseudosynclinal basins formed by sheet planes in valleys contain much ground water. Wells drilled in lowlands in sheeted terranes almost invariably produce greater quantities of water than those drilled on uplands.

1950. Ground water in the French Broad River basin, North Carolina, in Hydrologic data on the French Broad River basin, 1857-1945: N. C. Div. Water Res. and Eng., p. 160-177, 2 figs.

The basin lies within the mountain division of the Appalachian physiographic province. Ground-water occurrence is described for gneiss, hornblendic rocks, granite, and sedimentary rocks.

Data for the 2,825-sq-mi area include 67 well and 7 spring records, 5 chemical analyses, and a geologic map adapted from an existing source.

1952a. Solution depressions in diorite in North Carolina: Am. Jour. Sci., v. 250, p. 566-585, 3 figs.

Diorite has a relatively high solubility and yields more than three times 
as much mineral matter to solution than does granite. Such solution has produced depressions on nearly flat interstream areas.

Data include 42 chemical analyses of water samples from wells, springs, and streams.

1952b. Ground water in the Roanoke and Tar River basins, North Carolina, in Hydrologic data on the Roanoke and Tar River basins, 1871-

1945: N. C. Div. Water Res. and Eng., p. 98-132, 1 fig.

Data for the 3,375-sq-mi area include 202 well records, 76 chemical analyses, and a geologic map adapted from published sources.

1952c. (and Mundorff, M. J.). Geology and ground water in the Charlotte area, North Carolina: N. C. Div. Min. Res. Bull. 63, 88 p., 22 fig:s.

Statistical analyses are made of well data, particularly in relation to their topographic location as an index to their yield. Well yields are generally less than $30 \mathrm{gpm}$.

The 2,834-sq-mi area covers Cabarrus, Cleveland, Gaston, Lincoln, Mecklenburg, Polk, and Rutherford Counties. Data include 981 well records, 13 chemical analyses, and a bedrock geologic map for each of the counties (scale about $1: 270,000$ ).

1953a. Streamlining of the Carolina bays: Jour. Geology, v. 61, no. 3, p. 263-274, 1 pl., 2 figs.

A hypothesis is advanced that solution in a near-surface artesian aquifer composed of limestone resulted in subsidence of overlying clay into this aquifer, thus forming a normal sink. This condition was followed by streamline ground-water flow around the clay obstruction, causing an increased rate of solution and subsidence in the downgradient side of the sink. Slow but continuous flow around the clay eventually enlarged the dissolved area into an ellipsoid or ovoid, the more pointed end of which is downgradient.

1953b. Ground water in the Little Tennessee and Hiwassee River basins, North Carolina, in Riley, W. H., and LeGrand, H. E., Hydrologic data on the Little Tennessee and Hiwassee Rivers, 1873-1945: N. C. Div. Water Res. and Eng., p. 147-155, 1 fig.

A reconnaissance report. Data include one 10-year hydrograph, 58 well records, and 7 chemical analyses.

1954. Geology and ground water in the Statesville area, North Carolina:

N. C. Div. Min. Res. Bull. 68, 68 p., 20 figs.

More than 80 percent of existing wells are on upland areas where conditions are unfavorable for large supplies of ground water. The average yield of wells on hills is about half that of wells in other topographic locations and several times less than that of wells in draws.

The 2,556-sq-mi area includes Alexander, Catawba, Davidson, Davie, Iredell, and Rowan Counties. Data include 828 well records and 66 chemical analyses. Geologic maps are given for each of the counties (scale about $1: 360,000)$.

1955a. Brackish water and its structural implications in the Great Carolina Ridge, North Carolina: Am. Assoc. Petroleum Geologists Bull., v. 39 , no. 10 , p. 2020-2037, 6 figs.

Surficial brackish water in Bladen County, North Carolina, is unusual because of its surficial occurrence in the hinterland. It is believed to represent artesian water rising to the land surface, presumably along a fault, 
through breached clay beds and unconsolidated sands. The fault, trending slightly east of north, marks the west border of a broad domed area of brackish water west of Wilmington. The northeast-trending structures form a barrier of low permeability which has retarded the flushing of salty water from the artesian beds.

1955b. (and Broadhurst, S. D.). Ground-water resources in the Charlotte area, North Carolina: N. C. Div. Min. Res. Special Rept. (dupl.), 11 p., 2 figs.

Data for the 195-sq-mi area include 45 well records, a chemical analysis, and a map of bedrock geology of Mecklenburg County (scale about 1:230,000).

1955c. (and Brown, P. M.). Guidebook of excursion in the Coastal Plain of North Carolina, October 8-9, 1955: Carolina Geol. Soc., 43 p., 3 figs.

Maps (scale about 1:800,000) shows generalized geology of the Coastal Plain of North Carolina, top of the Peedee formation, and top of Precambrian basement rocks.

LeMoine, Rémy C. See Taylor, G. C., Jr., 49d, 49e, 50.

Leonard, Alvin R. See also Frye, J. C., 49b, 54; Fishel, V. C., 55.

1952. Geology and ground-water resources of the North Fork Solomon

River in Mitchell, Osborne, Smith, and Phillips Counties, Kansas:

Kans. Geol. Survey Bull. 98, 150 p., 10 pls., 18 figs.

Chief aquifers are alluvial deposits which range in age from Pleistocene (Kansan) to Recent. Relation of ground water to surface water is discussed.

Data for the 200-sq-mi area include 244 well records, 107 test-hole logs, 10 well logs, 7 measured sections, and 34 chemical analyses. Illustrations include a water-level map, longitudinal profiles of the North Fork Solomon River valley, 7 geologic cross sections, and a geologic map (scale about $1: 85,000)$.

\section{Liesch, Bruce A.}

1955. Records of wells, water levels, and quality of water in the Sammamish Lake area, King County, Washington: U. S. Geol. Survey dupl. rept., 193 p., 4 pls., 1 fig.

Glacial sand and gravel are the chief aquifers. The best yielding wells range in depth from less than 100 to $500 \mathrm{ft}$. Many wells yield 200 to $300 \mathrm{gpm}$ and a few are capable of yielding more than $1,000 \mathrm{gpm}$.

Data include 785 well and 25 spring records, 267 well $\operatorname{logs}$, and 19 chemical analyses.

\section{Littleton, Robert T.}

1949. Geology and ground-water hydrology of the Angostura irrigation project, South Dakota, with a section on mineral quality of the waters

by H. A. Swenson: U. S. Geol. Survey Circ. 54, 96 p., 2 pls., 12 figs.

Terrace lands to be irrigated with water stored in the Angostura Reservoir lie along the Cheyenne River in Fall River and Custer Counties, South Dakota. The terrace deposits rest on impermeable shale bedrock and are overlain in places by windblown sand and by slope wash from higher bedrock exposures. Ground water occurs in the terrace deposits, but the zone of saturation is generally thin and in places is absent. Application of irrigation water will raise ground-water levels and may cause waterlogging, especially in the area known as Harrison Flats, unless adequate preventive measures 
are taken. Inasmuch as the river water is more highly mineralized than the ground water in the terrace deposits, the ground water probably will become more highly mineralized as a result of the mixing of the two. Ground water also occurs under water-table conditions in the river alluvium, and artesian supplies are available throughout the area at depths ranging up to 3,000 $\mathrm{ft}$.

Data for the 70-sq-mi area include 174 well and spring records, 87 test-hole $\operatorname{logs}, 1$ well log, water-level data, 10 chemical analyses, and a geologic map (scale 1:63,360).

1950a. Ground-water conditions in the vicinity of Gillette, Wyoming, with a section on quality of ground waters by H. A. Swenson: U. S. Geol. Survey Circ. 76, 43 p., 3 pls., 2 figs.

The Gillette area is in a part of the Powder River structural basin, in which there are no perennial streams and water is obtained entirely from wells and springs. The area is underlain by the Wasatch and Fort Union formations, of Tertiary age, and the Lance, Fox Hills, Pierre, and older formations of pre-Tertiary age. Water is found principally in the Wasatch and Fort Union formations, at depths ranging from a few tens of feet to 2,200 ft; some of it is of poor quality. The Lance and Fox Hills formations and older strata carry some water; at depths ranging from 2,200 ft downward possibly to $10,000 \mathrm{ft}$, but the water generally is highly mineralized. The best prospects for future development of water appear to lie in test drilling to locate the most productive sandstone beds in the Wasatch and Fort Union formations that contain water of good quality. Springs issuing from clinker beds in the Fort Union formation $14 \mathrm{mi}$ northeast of Gillette are another potential source of water.

Data for the 168-sq-mi area include 56 well records, 6 test-hole-logs, 4 well logs, 2 geologic cross sections, and 13 chemical analyses.

1950b. Reconnaissance of the geology and ground-water hydrology of the Laramie Basin, Wyoming, with special reference to the Laramie and Little Laramie River valleys: U. S. Geol. Survey Circ. 80, 37 p., 2 pls., 6 figs.

Approximately 82,000 acre-ft of water is lost annually from the Laramie and Little Laramie Rivers above Two Rivers junction. Most of the water loss is accounted for by evapotranspiration losses from extensive hay meadows irrigated by the flooding method; however, a considerable amount of the loss is due to transpiration by trees and shrubs that line the streams and to evaporation from small water-table lakes and from areas where the water table is at or close below the land surface. Detailed geologic and hydrologic studies are needed to determine the feasibility of salvaging some of the water for reuse downstream.

Data include 54 well records, 1 well $\log$, a cross section of the Laramie Basin, and a geologic map (scale about 1:140,000) of Albany County by David Love.

1950c. Reconnaissance of the ground-water resources of the Wheatland

Flats area, Wyoming: U. S. Geol. Survey Circ. 70, 32 p., 1 pl., 3 figs.

Agricultural lands in the Wheatland Flats area, Platte County, are irrigated with water diverted from tributaries of the Laramie River. In a year of low runoff, a shortage of irrigation water occurs near the end of the growing season, owing in part to seepage losses from irrigation canals and laterals cut into permeable gravel. Discussed briefly are the possibilities of augmenting present surface-water supplies by pumping from the ground-water 
reservoir, which at the same time would relieve waterlogging that has occurred locally.

Data for the 100-sq-mi area include 58 well records and a geologic map (scale about 1:60,000).

Livingston, Penn. See also Barnes, B. A., 47.

1945. Ground-water resources of Sherman, Texas: Tex. Board Water Engineers, 23 p., 1 pl., 2 figs.

Data include 20 well records, 7 well logs, 7 chemical analyses, and results for aquifer tests of the lower part of the Paluxy sand and of the Woodbine sand.

1947a. Relationship of ground water to the discharge of the Leona River in Uvalde and Zavala Counties, Texas: Tex. Board Water Engineers dupl. rept., 52 p., 2 pls., 4 figs.

The report describes the geology; gives periodic measurements of spring flow, streamflow, and water levels in wells; and lists altitudes of springs along the Leona River.

1947b. Ground-water resources of Bexar County, Texas: Tex. Board Water Engineers dupl. rept., 234 p., 2 pls., 2 figs.

This report is essentially a compilation of the basic data used in preparing Water-Supply Paper 773-B (Water resources of the Edwards limestone in the San Antonio area, Texas) plus some additional well records.

Data for the 1,247-sq-mi county include 981 well records, 245 well logs, periodic measurements of water level in 47 wells, a well hydrograph (191146), 58 complete and 144 partial chemical analyses, and a geologic map based on the 1937 geologic map of Texas.

Loeltz, Omar J. See also Fredericks, J. C., 47; Robinson, T. W., 51.

1949. (and Phoenix, D. A., and Robinson, T. W.). Ground water in Paradise Valley, Humboldt County, Nevada: Nev. State Engineer Water Res. Bull. 10, 61 p., 2 pls., 2 figs.

Ground water in alluvial material is usually less than $10 \mathrm{ft}$ below the land surface. In general it is suitable for domestic use and for irrigation of all but the most sensitive crops. Part of the water now discharged naturally can be salvaged by lowering the water table through pumping. This would reduce both underflow and evapotranspiration losses. A lowering of about $20 \mathrm{ft}$ would make available about 15,000 acre-ft annually.

Of the $1,600 \mathrm{sq} \mathrm{mi}$ in the drainage basin, only $600 \mathrm{sq} \mathrm{mi}$ lies in the valley proper. Data for the valley area include 113 well records, 11. well logs, 11 chemical analyses, and a water-level map.

1953. (and Eakin, T. E.). Geology and water resources of Smith Valley, Lyon and Douglas Counties, Nevada: U. S. Geol. Survey Water-Supply Paper 1228, 89 p., 5 pls., 6 figs.

The geology and physical features are discussed with emphasis on their relation to the occurrence and movement of water. The West Walker River, which crosses the valley, has an average flow of about 180,000 acre ft per yr. About one-third of this flow is used for irrigation in the valley. Groundwater discharge probably exceeds 25,000 acre-ft per $\mathrm{yr}$. Of this amount, about 3,000 acre-ft is discharged from wells, 1,000 acre-ft by springs, and a few thousand acre-ft by evapotranspiration. About 18,000 acre-ft. is discharged into the West Walker River. South of the river several thousand 
acre-ft of ground water could be withdrawn each year without seriously lowering the piezometric surface, provided withdrawal is not concentrated in too small an area. In the northern part of the valley an additional 1,000 acre-ft of ground water, or slightly more, probably could be developed for irrigation.

Data for the 510 -sq-mi area include 160 well records, 16 test-hole $\operatorname{logs}, 28$ chemical analyses, a water-level map, and a geologic map (scale about $1: 125,000)$.

1955. (and Phoenix, D. A.). Geology and ground-water resources of Buena Vista Valley, Pershing County, Nevada, with a statement on reconnaissance land classification by H. G. Mason: Nev. State Engineer Water Res. Bull. 13, 51 p., 1 pl., 3 figs.

The best prospects for obtaining large supplies of water are sand and gravel aquifers underlying the fine-grained alluvial apron. The consolidated rocks of the mountains yield only small supplies from joints, beddingplane openings, and fault zones. Average recharge of about 10,000 acre-ft per $\mathrm{yr}$ is in balance with the average annual discharge. Most of the discharge is by evapotranspiration, the discharge from springs and wells being only about 400 acre-ft per yr.

Data for the 800-sq-mi valley include 32 well records, 10 well logs, and 12 chemical analyses. A reconnaissance map (scale about 1:150,000) shows geologic and hydrologic features.

Lofgren, Ben E. See also Fix, P. F., 50; Thomas, H. E., 52e, 52d.

1954. Ground-water possibilities of bedrock aquifers in southeastern Utah, in Progress report on selected ground-water basins in Utah: Utah State Engineer Tech. Pub. 9, p. 105-118, 4 figs.

Bedrock aquifers are becoming increasingly important as sources of ground water in southeastern Utah. Five formations known to yield water include the Dakota, Entrada, Navajo, and Wingate sandstones, and the Shinarump conglomerate. Data include 4 well $\operatorname{logs}, 12$ well records, and a geologic map of the Blanding-Montezuma Valley area (scale about 1:200,000).

1955. Résumé of the Tertiary and Quaternary stratigraphy of Ogden Valley, Utah, in Tertiary and Quaternary geology of the eastern Bonneville basin: Utah Geol. Soc. Guidebook to the geology of Utah, no 10 , p. 70-84, 3 figs.

Ogden Valley offers a unique hydrologic setting of an artesian reservoir covered in part by Pineview Reservoir, which inundates the lower third of the valley floor. Changes in surface loading by reservoir water affect not only the discharge of a group of flowing wells in operation on the submerged valley floor, but also the natural upward leakage through the artesian confining layer. A rise in the surface reservoir stage causes an increase in well discharge. Most of the increase is derived from the interception of natural leakage in the vicinity of the wells, and is accompanied by a decrease in underflow from the recharge area.

Lohman, Stanley W. See also Jacob, C. E., 52; Williams, C. C., 47, 49. 1951. General geology and ground-water resources of the Arkansas Basin in Colorado: Eighth Meeting of the Arkansas-White-Red River Basins Inter-Agency Committee, Granby, Colorado, app. E, p. E1-E7, July $18,1951$. 
Reviews the geology, ground-water resources, and ground-water investigations in the basin.

1952. Bibliography of published reports relating to ground water for the Arkansas-White-Red River basins; through Dec. 31, 1951: U. S. Geol. Survey dupl. bibliography, $26 \mathrm{p}$.

This bibliography is intended to supplement Hydrologic Atlas HA 2 (See Lohman 53c) showing the coverage of the principal ground-water reports for the basins. These basins lie in the States of Arkansas, Colorado, Kansas, Louisiana, Missouri, New Mexico, Oklahoma, and Texas.

1953a. Sand hills area, Nebraska, in Subsurface facilities of water management and patterns of supply-Type area studies: U. S. Cong., House Comm. Interior and Insular Affairs, Phys. and Econ. Found. Nat. Res., v. 4, chap. 5, p. 79-91, 10 figs.

About 25 percent of the precipitation recharges the ground-water reservoir, in late Tertiary and Quaternary unconsolidated deposits. As a result the flow of streams is largely dependent upon the discharge of ground water. The ground-water supply of the Sand Hills can be used most effectively in adjacent areas rather than in the area itself, as the soils generally are not favorable for irrigation.

1953b. High Plains of west-central United States, general aspects, in Subsurface facilities of water management and patterns of supplyType area studies: U. S. Cong., House Comm. Interior and Insular Affairs, Phys. and Econ. Found. Nat. Res., v. 4, chap. 4, p. 70-78, 5 figs.

In the High Plains most of the precipitation enters the soil and returns to the atmosphere by transpiration. Less than 1 percent of the precipitation is accounted for by direct runoff. Streams are sustained almost entirely by ground-water flow from the vast underground reservoir that underlies the Plains. The elements for a more effective utilization of the water supply are described and the deficiencies in current hydrologic data are listed.

1953c. Areas of principal ground-water investigations in the Arkansas, White, and Red River basins: U. S. Geol. Survey Hydrol. Inv. Atlas HA 2. Latitude, $31^{\circ}$ to $39^{\circ} \mathrm{N}$., longitude, $30^{\circ}$ to $106^{\circ} \mathrm{W}$. Scale $1: 2,500,000$ ( 1 inch $=$ about 40 miles $)$.

Areas covered by current detailed investigations are distinguished from those covered by earlier reconnaissance or detailed investigation. The numbered areas on the map are accompanied by a list of references to publications or titles of projects. Only those published reports or current groundwater investigations are included to which reference generally would be made in the solution of ground-water problems in specific areas. The map shows also, by counties, the number of observation wells in which groundwater levels are currently being measured by the Geological Survey and its cooperating State and local agencies.

1953d. (and Burtis, V. M.). General availability of ground water and depth to water level in the Arkansas, White, and Red River basins: U. S. Geol. Survey Hydrol. Inv. Atlas HA 3. Latitude, $31^{\circ}$ to $39^{\circ} \mathrm{N}$., longitude, $90^{\circ}$ to $106^{\circ} \mathrm{W}$. Scale, $1: 2,500,000$ ( 1 in. to about $40 \mathrm{mi}$.).

Colors show areas where yields of individual wells are generally less than $50 \mathrm{gpm}, 50$ to $500 \mathrm{gpm}$, or more than $500 \mathrm{gpm}$. Patterns show areas of different depths to water. 
1954. Measurement of ground-water lcvels by air-line method: U. S. Geol. Survey dupl. rept., 4 p., 1 fig.

Describes a method for measuring water levels in wells being pumped.

Lohr, Edwin W.

1954a. (and Love, S. K.). The industrial utility of public water supplies in the United States, 1952; part 1-States east of the Mississippi River: U. S. Geol. Survey Water-Supply Paper 1299, 639 p., 5 pls., 3 figs.

Descriptions and analyses of the public water supplies are given for 819 of the larger cities in the States east of the Mississippi River. Data, given for all cities of 15,000 or more (1950 census) and for many smaller cities, include population; population supplied; ownership of the system; source and treatment of the water; storage facilities for both raw and finished water; and chemical analyses of the supplies.

The first 49 pages contain summaries of the analytical data reported, including statistical tables and illustrations that show the hardness of public water supplies, and brief discussions of the treatment of water in the 819 larger cities east of, and 496 of the larger cities west of, the Mississippi River.

1954b. (and Love, S. K.). The industrial utility of public water supplies in the United States, 1952; part 2-States west of the Mississippi River: U. S. Geol. Survey Water-Supply Paper 1300, 462 p., 5 pls., 3 figs.

This paper is companion to Water-Supply Paper 1299 (see Lohr 54a). It contains data, similar to those in Water-Supply Paper 1299, for 496 of the larger cities in the States west of the Mississipi River. The first 49 pages of the two papers are identical.

\section{Lorenz, Howard W.}

1951. (and Swenson, F. A.). Geology and ground-water resources of the Helena Valley, Montana, with a section on chemical quality of the water by H. A. Swenson: U. S. Geol. Survey Circ. 83,68 p., 4 pls., 11 figs.

The Helena Valley is a small intermontane basin. Its floor is underlain by Tertiary "lake beds," which are mantled by younger alluvial fans in much of the valley. Alluvial fans and "Lake beds" are the chief aquifers. Approximately 8,500 acres of formerly productive farmland in the lower part of the valley is waterlogged as a result of the increased ground-water recharge caused by irrigation of the higher lands in the valley. If more lands in the higher part of the valley are irrigated, the waterlogged area will increase in size unless provision is made either to prevent additional groundwater recharge or to recover and dispose of the excess ground water. The possibility of pumping surplus ground water in the waterlogged area for use in the irrigation of farmland in other parts of the valley is suggested. Ground water in the Helena Valley is of good chemical quality.

Data for the 300-sq-mi area include 188 well records, 1 test-hole log, periodic water-level measurements, 20 chemical analyses, a water-level map and a geologic map (scale 1:63,360). 
Louisiana Department of Public Works Planning Division.

Sections on ground water, in reports entitled "Parish resources and facilities":

1946. Acadia Parish, p. 34-36

1947. Ascension Parish, p. 29-30

1949. Beauregard Parish, p. 37

1951. Bienville Parish, p. 55-56.

1947. Cameron Parish, p. 28-29

1948. Catahoula Parish, p. 33-35

1948. Claiborne Parish, p. 33-35

1949. DeSoto Parish, p. 32

1951. East Carroll Parish, p. 54-56

1947. Grant Parish, p. 66-67

1949. Iberia Parish, p. 55-61

1947. Jackson Parish, p. 38

1953. Lafayette Parish, p. 50-55

1943. Lincoln Parish, p. 45-48

1953. Madison Parish, p. 36-37

1950. Morehouse Parish, p. 38-40

1946. Pointe Coupe Parish, p. 33-34

1948. Red River Parish, p. 27

1952. Richland Parish, p. 37-38

1953. St. Charles, p. 31-35

1947. St. Charles Parish, p. 26-28

1955. St. John the Baptist Parish, p. 31-33

1947. St. Landry Parish, p. 35-38

1949. St. Martin Parish, p. 45-47

1949. St. Mary Parish, p. 31-32

1955. St. Tammany Parish, p. 37-38

1949. Tensas Parish, p. 29-30

1953. Terrebonne Parish, p. 42-44

1954. Union Parish, p. 45-46

1946. Vermilion Parish, p. 33-35

1949. Vernon Parish, p. 28-30

1947. West Baton Rouge Parish, p. 29-32

1951. West Carrol Parish, p. 42-44

These are brief discussions of ground-water occurrence based on interpretation of geologic maps, electric logs, and other data, if available. Each includes one or more chemical analyses. The sections were prepared by Paul H. Jones, Glen Scarcia, and A. N. Turcan, Jr., of the Geological Survey, although no authorship is shown in the reports themselves.

Love, S. Kenneth. See also Ferguson, G. E., 47; Lohr, E. W., 54a, 54b; Parker, G. G., 55c; Schroeder, M. C., 54b.

1955. Quality of ground and surface waters, in Water resources of southeastern Florida: U. S. Geol. Survey Water-Supply Paper 1255, p. 727833, figs. 213-222.

Numerous chemical analyses are given of both ground and surface water.

Lusczynski, Norbert $\mathbf{J}$.

1950. Withdrawal of ground water and pond water on Long Island from 1904 to 1949: U. S. Geol. Survey dupl. rept., 4 p., 1 fig.

Pumpage data are given for public and other systems. 
1951. (and Johnson, A. H.). The water table in Long Island, New York, in January 1951: N. Y. Water Power and Control Comm. Bull. GW27, 28 p., 4 pls.

The report reviews the early ground-water records for Long Island. Illustrations include a water-level map for January 1951 and profiles of the water table for 1903 and 1951. Well records and water-level measurements are tabulated for 533 shallow wells used in preparing the map. The map (scale about $1: 170,000$ ) is in three sections.

1952. The recovery of ground-water levels in Brooklyn, New York, from 1947 to 1950: U. S. Geol. Survey Circ. 167, 29 p., 2 pls., 12 figs.

As a result of condemnation proceedings by the City of New York, the New York Water Service Corp. on June 29-30, 1947, closed down permanently its entire ground-water facilities, with a resultant reduction of more than $\mathbf{5 0}$ percent in the net ground-water withdrawal in Kings County (Brooklyn). The water table, far below sea level for many years, recovered as much as 19 feet at some places in central Brooklyn from June 1947 to December 1950.

Chloride determinations, water-level data, contour maps, profiles, and hydrographs of ground-water levels for the period 1903-50 are presented and discussed. The report includes a compilation of the withdrawals by public water-supply companies and industrial concerns, and a brief review of the geology of Kings County.

MacCary, L. M.

1955. Map of the Louisville area, Kentucky, showing contours on the bedrock surface: U. S. Geol Survey Hydrologic Atlas HA 5; scale, 1 inch = about 4,700 feet; contour interval, 10 feet; 22 by 27 inches.

The configuration of the bedrock surface beneath the alluvium in the Louisville area is important in that it helps determine the thickness of the alluvial aquifer. This map was compiled from maps published in several earlier reports and from more recent data. Locations of the wells, test borings, exposures, and resistivity sites used in the compilation are shown on the map.

MacDonald, Gordon A. See also Stearns, H. T., 46, 47.

1947a. Bibliography of the geology and water resources of the Island of Hawaii, annotated and indexed: Hawaii Div. Hydrography Bull. 10, $191 \mathrm{p}$.

All of the known papers dealing with the geology, volcanoes, ground water, and surface water of the island are listed alphabetically by author and with annotations.

1947b. Ground-water resources of the Island of Molokai, in Geology and ground-water resources of the Island of Molokai, Hawaii: Hawaii Div. Hydrography Bull. 11, p. 37-87, pl. 1, figs. 6-17.

Nearly all the Island of Molokai is underlain, close to sea level, by ground water of the basal zone of saturation. Basal water is brackish beneath West Molokai, in the Hoolehua Plain between West and East Molokai, and in the southern coastal area of East Molokai. Beneath much of East Molokai, fresh basal water is obtainable. At high levels in East Molokai small amounts of fresh water are perched on thin, poorly permeable ash beds and larger supplies that can be developed by tunnels are confined in permeable compartments between poorly permeable dikes in the rift zones. 
Data for the 260-sq-mi island include 100 well and tunnel records, 2 chemical analyses, and an areal geologic map (scale 1:62,500).

McDonald, H. R.

1947a. (and Wolcott, H. N., and Hem, J. D.). Geology and ground-water resources of the Salt River valley area, Maricopa and Pinal Counties, Arizona: U. S. Geol. Survey dupl. rept., 45 p., 4 pls., 3 figs.

The chief aquifer is sand and gravel in alluvium. Recharge is from four sources: (1) seepage from canals and irrigated areas, (2) streamflow, (3) underflow of streams, and (4) rainfall. Over pumping and drought have combined to lower water levels and to increase the salt content of ground water in the lower part of the valley.

Data include 52 well records, 4 well $\operatorname{logs}$, and 23 chemical analyses. Maps show depth to water in 1913 and 1945, distribution of dissolved solids, and areal geology (scale about 1:340,000). For a more recent report see Halpenny 52.

1947b. (and Wolcott, H. N., and Bluhm, F. I.). Geology and ground-water resources of Paradise Valley, Maricopa County, Arizona, with a section on Quality of water, by J. D. Hem: U. S. Geol. Survey dupl. rept., 34 p., 1 pl., 1 fig.

Wells in alluvial fill yield as much as $1,800 \mathrm{gpm}$. The "safe yield" of the valley is estimated at 6,700 acre-ft per yr.

Data include 89 well records, 13 well logs, 16 chemical analyses, and a geologic map (scale about 1:210,000).

McGuinness, Charles L. See also Fiedler, A. G., 48; Sayre, A. N., 54.

1947a. Recharge and depletion of ground-water supplies: Am. Soc. Civil

Engineers Trans., v. 112, p. 972-998, 8 figs.

Changes in ground-water levels are caused by climatic changes or by human activities that affect the rates at which the ground-water reservoirs are recharged and discharged. Evidence fails to show that changes in groundwater levels due to deforestation, drainage, and land cultivation have been progressive over long periods in most parts of the United States.

1947b. Geology and ground-water resources of Puerto Rico: Econ. Geology, v. 42, no. 6, p. 563-571, 10 figs.

The chief aquifer is Quaternary sand and gravel, which yields about 200 mgd to wells in the main south coastal plain alone. Metamorphosed Upper Cretaceous volcanic and associated rocks yield small supplies of water to wells in most places. Tertiary limestones yield large supplies in some places on the north, south, and west coasts. About 250 to $300 \mathrm{mgd}$ is pumped from wells in the 3,349-sq-mi island, and moderate to large additional supplies are available in some places.

1948. Ground-water resources of Puerto Rico: Puerto Rico Aqueduct and Sewer Service dupl. rept., 613 p. (Accompanied by volume containing well records and geologic and well-location maps, 255 p., 5 pls., released in August 1946.)

Chief aquifers are, on the north coast, Tertiary limestones containing numerous solution channels; and, on the south, east, and west coasts, Quaternary sand and gravel of the coastal plain. Large additional supplies of ground water are believed to be available on the west coast in the Guanajibo and Añasco Valleys, on the north coast in parts of the Aguadilla- 
Arecibo and Arecido-Bayamón sections, and on the east coast in the Yabucoa Valley. The south coast, the most heavily pumped area, is fully developed except locally.

Data for the 3,349-sq-mi main island include 950 well records, 500 well logs, and 44 chemical analyses. A geologic map (scale about 1:300,000) is adapted from existing sources.

1949. (and Poindexter, O. F., and Otton, E. G.). Ground-water supplies of the Ypsilanti area, Michigan: U. S. Geol. Survey Water-Supply Paper 1078, 105 p., 5 pls., 7 figs.

The chief aquifers are sand and gravel of glacial origin. The report based on work done during World War II, shows that the local ground-water supply would be ample to meet war needs and that still larger supplies could be developed through careful exploration and test pumping.

Data for the 90-sq-mi area include 140 well records, 13 test-hole logs, 101 well logs, 20 chemical analyses, water-level measurements, and aquifer tests of glacial sands and gravels. The map of surficial geology (scale 1:126,720) is based on a published source.

1951a. The water situation in the United States, with special reference to ground water, with a summary of the current situation by States based on data supplied by field offices of the Water Resources Division: U. S. Geol. Survey Circ. 114, 138 p. plus appendix of 127 p., 20 figs.

Circular 114 comprises appendixes $B$ and $C$ of a report prepared by the Geological Survey in April 1950 for the President's Water Resources Policy Commission. It describes the principles of occurrence of ground water, especially in relation to surface water, describes the general occurrence of ground water in the United States, and summarizes briefly the current water situation. It contains a selected reading list in hydrology and ground water. The appendix (appendix $\mathrm{C}$ of the original report) consists of a brief summary of the water situation in each State, including a description of current problems, deficiencies in basic data, and possible solutions. Great stress is laid on the deficiency of basic hydrology data and on the need for gathering such data as the first step in water development. The report emphasizes also the necessity of consistent legal treatment of water-rights problems and introduces the subject of water law.

Maps of the United States show ground-water areas (by H. E. Thomas); areas of substantial ground-water information; and ground-water pumpage in 1945 for municipal, industrial and irrigation uses (by W. F. Guyton).

1951b. Water law, with special reference to ground water: U. S. Geol. Survey Circ. $117,30 \mathrm{p}$.

This report was prepared at the request of the President's Water Resources Policy Commission. It discusses water law, especially ground-water law, from the standpoint of the hydrologist. It describes the two major systems of water law: the common-law riparian system and the prior-appropriation system. It discusses a number of difficulties encountered in the enforcement of existing law and the formulation of new statutes. Many of the difficulties stem from the attempt to subdivide water into types that are treated differently under the law, whereas the assumed differences do not exist in nature. Difficulty arises also from excessively strict interpretation of old water rights, which discourages new development. The report concludes with an appendix describing briefly, for each State, the major provisions of existing law controlling the diversion of water. 
1954. (and Poland, J. F.). Availability of primary or juvenile water for ordinary uses: U. S. Geol. Survey dupl. rept., 5 p.

True juvenile water may be expected to be highly mineralized under any and all circumstances. In any place where the proportions of the chemical constituents indicate juvenile rather than meteoric origin, if the water is dilute enough for ordinary uses it must have been mixed with meteoric water. Therefore, it cannot be considered to constitute a source independent of other fresh-water supplies in the same hydrologic basin.

\section{MacKichan, Kenneth A.}

1951. Estimated use of water in the United States, 1950: U. S. Geol. Survey Circ. 115, 13 p., 6 figs.

Presents in graphic and tabular form an inventory of water use, by States, for various basic purposes: rural, domestic, and stock supply; municipal supply; industrial supply from private sources; irrigation; and water power. The amount withdrawn from surface-water supplies and from ground-water supplies for each State for each purpose also are indicated. Our modern economy requires the use of huge quantities of water. The 1950 use is estimated to have been $170,000 \mathrm{mgd}$. This amounted to $1,100 \mathrm{gpd}$ for each person in the United States. An additional 1,100,000 mgd was used to generate water power. In 1950, estimated ground-water withdrawal was 2,858 mgd for rural use, 3,584 $\mathrm{mgd}$ for municipal use, and 5,525 $\mathrm{mgd}$ for industrial use; estimated irrigational use was 20,204 acre-ft per $\operatorname{yr}(17,982$ mgd). Nonwithdrawal uses, such as navigation, waste disposal, recreation, and fish and wildlife, also are discussed and evaluated.

McLaughlin, Thad G. See also Byrne, F. E., 48.

1946a. Geology and ground-water resources of parts of Lincoln, Elbert, and El Paso Counties, Colorado, with special reference to Big Sandy Creek valley above Limon: Colo. Water Conserv. Board, Ground-Water Ser. Bull. 1, 139 p., 6 pls., 15 figs.

The chief aquifers are the alluvium and terrace deposits in the principal valleys. Recharge now balances discharge but the total supply of ground water for irrigation will increase as the water table is lowered by increased pumping, which will reduce the discharge of ground water by transpiration, evaporation, and seepage into streams and increase recharge both from precipitation and by seepage from streams.

Data for the 1,440-sq-mi area include 171 well records, 38 test-hole logs, 56 well logs, and 30 chemical analyses. Data are given for aquifer tests of alluvium in Big Sandy Valley. Illustrations show 10 cross sections across Big Sandy Valley and an areal geologic map (scale 1:125,000).

1946b. Ground water at Dickinson, North Dakota, with a section on geology, by A. L. Greenlee: U. S. Geol. Survey N. Dak. Ground Water Studies 3, 31 p., 6 figs.

The early Tertiary sediments in the area consist predominantly of clay and fine sand. Large :quantities of potable ground-water are virtually unobtainable.

Data for the 1-sq-mi area include 8 well records, 2 test-hole logs, and aquifer-test data for the Fort Union formation.

1946c. Geology and ground-water resources of Grant, Haskell, and Stevens Counties, Kansas: Kans. Geol. Survey Bull. 61, 221 p., 12 pls., 18 figs.

The chief aquifers are Pliocene and Pleistocene deposits. Ground water 
moves eastward through the area under a gradient that ranges from $5 \mathrm{ft}$ per mi in eastern Haskell County to $50 \mathrm{ft}$ per $\mathrm{mi}$ in southeastern Grant County. Depths to water range from less than $10 \mathrm{ft}$ in parts of the valleys of the Cimarron River and its tributaries to almost $250 \mathrm{ft}$ in the upland area of western Haskell County.

Basic data for the 1,881-sq-mi area include 356 well records, 46 test-hole logs, 14 well $\operatorname{logs}, 7$ measured geologic sections, and 77 chemical analyses. Interpretive data include a water-level map; a depth-to-water map; a geologic fence diagram; a map showing the southern limits of the Dakota, Kiowa, and Cheyenne formations, in the area; a map of the pre-Tertiary surface; data for aquifer tests on the Rexroad(?) and Meade formations; and a geologic map (scale about 1:140,000).

1948. Ground water in the Julesburg area, Colorado: Colo. Water Conserv. Board, Ground-Water Ser., Circ. 1, 20 p., 2 figs.

Moderate to large ground-water supplies can be developed only in the alluvium of the South Platte Valley and Lodgepole Valley. Included are 8 test-hole logs, 2 geologic cross sections, and 7 chemical analyses.

1949. Geology and ground-water resources of Pawnee and Edwards Counties, Kansas: Kans. Geol. Survey Bull. 80, 189 p., 9 pls., 12 figs.

Aquifers that have large yields are the Meade formation and alluvium in the Pawnee and Arkansas Valleys. The Dakota sandstone furnishes small to moderate yields of soft, mineralized water generally high in fluoride.

Data for the 1,368-sq-mi area include 360 well records, 131 test-hole logs, 13 well logs, and 71 chemical analyses. Illustrations include a water-level map, a geologic fence diagram, and an areal geologic map (scale 1:126,720).

1953. Ground water in Colorado and the status of investigations: Colo. Water Conserv. Board, Ground-Water Ser., Circ. 4, 24 p., 1 fig.

Several areal ground-water studies have been made, but more data are needed to solve existing problems, to anticipate and avoid future problems, and to enable the State to prepare and administer a sound and equitable ground-water code.

1954. Geology and ground-water resources of Baca County, Colorado: U. S. Geol. Survey Water-Supply Paper 1256, 232 p., 2 pls., 54 figs., issued also as Colo. Water Conserv. Board Ground-water Ser. Bull. 2, 1955.

The chief aquifers are the Cheyenne sandstone member of the Purgatoire formation, Dakota sandstone, Ogallala formation, and alluvium in the major valleys. Although the Cheyenne sandstone member is capable of yielding as much as $3,000 \mathrm{gpm}$ to individual wells, it transmits water slowly and cannot withstand large-scale development without serious declines of pressure head and without sharply reducing or stopping the flow of artesian wells.

Basic data for the 2,577-sq-mi area include 434 well and spring records, 4 measured sections, 20 test-hole logs, 124 well logs, and 60 chemical analyses. Interpretive data include water-level maps, a fence diagram, aquifer-test results for the Cheyenne sandstone member, and a geologic map (scale about $1: 125,000)$.

1955a. Hydrologic aspects of ground-water law: Am. Water Works Assoc. Jour., v. 47, no. 5, p. 447-452; Johnson Natl. Drillers Jour., v. 27, no. 3, p. 406, 15; Cross Section (Texas), v. 1, no. 12, p. 3-4.

Ground-water legislation is difficult to interpret and enforce because the 
current legal classifications of ground water are archaic, arbitrary, and scientifically unsound. Types of ground-water areas and problems are described to illustrate the difficulties in writing good laws.

1955b. Ground water in the Denver metropolitan area in Geology of Front Range foothills west of Denver: Rocky Mountain Assoc. Geologists

Field Conf. Guidebook, p. 60-67.

Ground water in the Arapahoe formation appears to be approaching exhaustion locally. Most of the water pumped is being taken from storage. Ground water in the Fox Hills sandstone has not been developed extensively but the rate of recharge is low and most of the water pumped appears to be coming from storage.

Maher, John C.

1951. Ground water, with reference to the oil industry: Petroleum Refiner, 6 p., 4 figs.

Reviews some of the basic principles of ground-water hydrology that apply to various phases of the oil industry, which is one of the largest users of water.

Mangan, J. W. See also Graham, J. B., $51 \mathrm{~b}$.

1952. (and Van Tuyl, D. W., and White, W. F., Jr.). Water resources of the Lake Erie shore region in Pennsylvania: U. S. Geol. Survey Circ. 174, 36 p., 23 figs.

Lake Erie is a source of an almost inexhaustible supply of water of satisfactory chemical quality. The average use of lake water in the region is $56 \mathrm{mgd}$. An adequate supply of water for many uses can be obtained from small streams and ground-water sources; average use from these sources is $2 \mathrm{mgd}$. A major expansion of ground-water use in the region does not appear feasible in the suburban sections of Erie, owing to the smallness of available supplies and low water levels in the summertime, danger of organic pollution in unsewered areas, and likelihood of chloride contamination from saline bedrock; however, the areas having the greatest ground-water potential are described. Figures and tables show the chemical characteristics of water from sand and gravel and from bedrock. Laws affecting the use or pollution of water in the areas are described briefly and a summary of the potential water resources of the area is given.

1953. (and Graham, J. B.). The use of water in Pennsylvania, 1951: U. S. Geol. Survey Circ. 257, 11 p., 5 figs.

Summarizes an inventory of water use by counties for rural, domestic, stock, public, and industrial supplies and water power. The amount withdrawn, by county and by use, from surface-water and ground-water sources is indicated. In 1951 almost 11,000 mgd was withdrawn for use in Pennsylvania and an additional $46,000 \mathrm{mgd}$ was used to generate water power. A further breakdown shows that, of the $11,000 \mathrm{mgd}, 9,724 \mathrm{mgd}$ was used by industry, $878 \mathrm{mgd}$ for public supplies, and $126 \mathrm{mgd}$ for rural supplies. Nonwithdrawal uses, such as navigation, water power, waste disposal, recreation, and commercial fishing are discussed, and future demands and outlook for water are evaluated.

\section{Marine, I. W.}

1954. Water levels and artesian pressures in Delaware, 1952: Del. Geol. Survey Water-Level Rept. 1, 11 p., 1 fig. 
An advance release of the data included in the Delaware section of the annual water-level report (See table 1 and figure 1 ).

1955. (and Rasmussen, W. C.). Preliminary report on the geology and ground-water resources of Delaware: Del. Geol. Survey Bull. 4, 336 p., 10 pls., 30 figs.

In northern Delaware, crystalline rocks of the Piedmont yield small quantities of ground water, but in the coastal plain, rocks of Cretaceous age form a series of artesian aquifers of moderate to high yield. In central Delaware two sands of Eocene age yield small to moderate quantities of ground water, but two artesian sand reservoirs of the Miocene series are capable of large yields. In central and southern Delaware, Pleistocene sand deposits form water-table reservoirs of large yield. About $30 \mathrm{mgd}$ ground water was pumped in Delaware in 1954. This is roughly one-sixteenth of the estimated optimum yield.

Data for the 2,370-sq-mi State include 1,081 well records, 392 well logs, and 92 chemical analyses. Maps of the State show the top of crystalline basement rock, top of the Matawan group, top of the Eocene series, base of the Pleistocene series, chief aquifers, and bedrock geology (scale about 1:500,000).

Mason, Arnold C. See Wentworth, C. K., 55 .

Maxey, George B. See also Dennis, P. E., 46; Eakin, T. E., 49, 51a, 51b. 1946. (and Jameson, C. H.). Well data in Las Vegas and Indian Spring Valleys, Nevada: Nev. State Engineer Water Res. Bull. 4, 128 p., 1 pl.

Data include 570 well records, 76 well logs, and 96 chemical analyses.

1947. (and Robinson, T. W.). Ground water in Las Vegas, Pahrump, and Indian Spring Valleys, Nevada (a summary): Nev. State Engineer Water Res. Bull. 6, 23 p., 1 pl., 5 figs.

The only source of water for the three valleys is precipitation on the higher areas of Spring and Sheep Mountains, but only a small part of this precipitation recharges the alluvial-fan and valley-fill materials that form the aquifers. Annual recharge in Las Vegas Valley is about 30,000 acre-ft, and in Pahrump Valley, about 25,000 acre-ft.

For a more complete report, see Maxey 48.

1948. (and Jameson, C. H.). Geology and water resources of Las Vegas, Pahrump, and Indian Spring Valleys, Clark and Nye Counties, Nevada: Nev. State Engineer Water Res. Bull. 5, 43 p., 9 pls., 13 figs.

Of the older rocks, only the Sultan limestone of Devonian age and Monte Cristo limestone of Mississippian age are important aquifers, but they usually occur above the regional ground-water level. Ground-water movement in the older rocks is impeded by faults. Annual recharge to the unconsolidated sediments in the valley is between 30,000 and 35,000 acre-ft.

Data for the 3,100-sq-mi area include 683 well records, 236 well logs, and 118 chemical analyses. Maps show areas of artesian flow, water levels, areas of bedrock and valley fill, and areal geology (scale about 1:125,000).

1949. (and Eakin, T. E.). Ground water in White River valley, White Pine, Nye, and Lincoln Counties, Nevada: Nev. State Engineer Water Res. Bull. 8, 59 p., 2 pls., 5 figs.

White River valley, in east-central Nevada, is a semiarid intermontane 
trough in the central part of the Great Basin. The chief aquifers are in the alluvial apron and stream deposits that underlie the valley. lowland. Water issuing from large springs in the alluvium is probably supplied from conduit systems in limestone. Ground-water recharge is about 53,000 acre-ft per yr and evapotranspiration is about 34,000 acre-ft per $\mathrm{yr}$.

Data include 98 well and 12 spring records, 13 well logs, and 3 chemical analyses. Maps show water levels at Lund and reconnaissance geology (scale about $1: 125,000)$.

1950 (1951). (and Eakin, T. E.). Ground water in Railroad, Hot Creek, Reveille, Kawich, and Penoyer Valleys, Nye, Lincoln, and White Pine Counties, Nevada, in Contributions to the hydrology of eastern Nevada: Nev. State Engineer Water Res. Bull. 12, p. 14-15, 127-171, pls. 4 and 5 .

Chief aquifers are sand and gravel deposits of Tertiary and Quaternary valley fill. Average recharge and discharge are about 50,000 acre-ft per yr.

Data for the 5,570-sq-mi area include 37 well and 18 spring records, 1 chemical analysis, and a reconnaissance geologic map (scale 1:500,000).

\section{Maxwell, Bruce W.}

1954. Public and industrial water supplies of the Western Coal Field region, Kentucky: U. S. Geol. Survey Circ. 339, 41 p., 3 pls., 2 figs.

More than $32 \mathrm{mgd}$ of ground water is pumped from the unconsolidated alluvial deposits along the Ohio River in the Western Coal Field region. About $3 \mathrm{mgd}$ is obtained from the consolidated rocks, chiefly sandstone beds of Pennsylvania age, in the rest of the region. Abundant surface water is available from the Ohio and Green Rivers and tributaries. Enough water is impounded in smaller streams for local use during periods of low flow. Except for the saline waters obtained at depths of several hundred feet in the bedrock, the waters are suitable, with treatment, for public and most industrial supplies. Saline waters are used successfully for coal washing and for secondary recovery of oil. Included in the report are two maps showing graphically the amount of water pumped at each location and the chemical character of the water. Tables give detailed information on the 88 supplies inventoried, including 41 chemical analyses. A generalized section shows the geologic formations in the area and their water-bearing characteristics. Per-capita use from public supplies ranges from 21 to $197 \mathrm{gpd}$.

Meinzer, Oscar E. See also Waring, G. A., 47.

1946a. General principles of artificial ground-water recharge: Econ.

Geology, v. 41, no. 3, p. 191-201.

The different methods of artificial recharge in relation to geologic structure and ground-water hydraulics are discussed and numerous examples are given. They include indirect methods, in which recharge is increased by locating production wells as close as practicable to areas of rejected recharge or natural discharge, and direct methods, in which recharge is increased by applying water at the surface or adding it through wells.

1946b. Hydrology in relation to economic geology: Econ. Geology, v. 41, no. 1, p. 1-12.

Reviews the geologic controls in hydrology and the hydrologic controls in geology. Discusses water as a mineral product.

1947a. Suggestions as to future research in ground-water hydrology: Am. Geophys. Union Trans., v. 28, no. 3, p. 418-420. 
Determination of the ground-water supply available from any aquifer or in any specified area requires not merely the application of specific quantitative methods but also a broad and accurate knowledge of the geologic, hydrologic, and geochemical factors that are involved, and consideration of the economic and legal limitations. Further research is needed as to geologic texture and structure in relation to the occurrence and movement of the water; the precise nature of specific yield, which determines the effective storage capacities of the aquifers; the molecular physics involved in the downward and upward movement of water in the zone of aeration, and quantitative evaluation of ground-water recharge and discharge; the hydraulics of ground water, as studied by aquifer-test methods, with special reference to boundary conditions; studies of perennial yield of aquifers of low permeability; the genesis of the mineral content of ground water as determined through appropriate geologic, hydrologic, and chemical studies; and methods of geophysical exploration and well logging for determining the occurrence of ground water. Serious study is needed also as to practicable methods of implementing the recently developed principles and methods of ground-water hydrology in the production of water supplies and the economic and legal problems involved.

1947b. Scientific management of ground-water resources is made possible by application of modern hydrology: Federal Science Progress, v. 1, no. 5, p. 31-33, 3 figs.; reprinted as Ground-water management: Water Well Jour., v. 1, no. 3, p. 9-11, 16, 1947.

1950. Geology and engineering in the production and control of ground water, in Application of geology to engineering practice: Geol. Soc. America, Berkey Volume, p. 151-179, 1 pl., 5 figs.

Reviews principles of hydrogeology and their applications in development of ground-water supplies and in control of ground water in engineering projects. Gives a general review of ground-water literature, especially for the period 1930-46.

Meyer, Gerald. See also Dingman, R. J., $54 \mathrm{~b}$.

1952. Ground-water resources of Prince Georges County, in Geology and water resources of Prince Georges County (Md.): Md. Dept. Geology, Mines and Water Res. Bull. 10, p. 82-257, pls. 3-6, figs. 4-9.

The important aquifers in the county are the Aquia greensand in the eastcentral part; sand of the Magothy formation in the southeastern half; the Patapsco formation in the north-central and northwestern parts; and the Patuxent formation in the northern, northwestern, and western parts.

Data for the 465-sq-mi county include 500 well records, 30 test-hole logs, 181 well $\operatorname{logs}$, and 55 chemical analyses. Illustrations include 2 geologic cross sections and maps showing the top of the sand in the Magothy formation, top of the Aquia greensand, bedrock (Precambrian) surface, and areal distribution of the Nanjemoy formation.

Meyer, Rex R. See also Bennett, R. R., 52.

1955a. (and Bennett, R. R.). Ground-water resources of the Salisbury area, in The water resources of Somerset, Wicomico, and Worcester Counties: Md. Dept. Geology, Mines and Water Res. Bull. 16, p. 171197, pls, 7, 9, 10, figs. 29, 30, 34, and 35 .

Ground-water runoff in the Beaverdam Creek basin during 14 years of record averaged $0.602 \mathrm{mgd}$ per sq $\mathrm{mi}$, which was about 27 percent of the 
precipitation. Total runoff was $0.764 \mathrm{mgd}$ per sq mi, which was 34 percent of the precipitation.

Data for the 55-sq-mi area are included in the report on Somerset, Wicomico, and Worcester Counties (Rasmussen 55).

1955b. (and Turcan, A. N., Jr.). Geology and ground-water resources of the Baton Rouge area, Louisiana: U. S. Geol. Survey Water-Supply Paper 1296, 138 p., 3 pls., 40 figs.

The chief fresh-water sands have been delineated and named in accordance with their depth below the surface, largely as identified in electric logs of wells in the industrial district. These sands range in age from Miocene to Recent and each is a separate hydrological unit. In 1953, about $65 \mathrm{mgd}$ of water was used in this area. Water from wells screened in the "400"" and "600-foot" sands of Pleistocene age and the "2,000-foot" sand of Miocene age constitutes about 70 percent of the total. The shallow deposits of Recent age adjacent to the Mississippi River will yield large quantities of hard water at a relatively low temperature.

Data for the 390-sq-mi area include 565 well records, 3 test-hole logs, 77 well logs, 2 geologic cross sections, 82 chemical analyses, and particle-size analyses. Sections are devoted to temperature versus viscosity (p. 17), earth temperature gradient (p. 72), and salt-water encroachment. Illustrations include geologic cross sections, and isopach and structure maps for the "400-" and "600-foot" sands. Results are given for 31 aquifer tests on the "400-", "600-", "800-", "1,200", "1,700", and "2,000-foot" sands.

Meyers, Joseph D.

1952. (and Newcomb, R. C.). Geology and ground-water resources of the Swan Lake-Yonna Valleys area, Klamath County, Oregon: U. S. Geol. Survey dupl. rept., 151 p., 10 pls.

The chief aquifers are two lava-rock formations that underlie the basins. These formations contain fractured and brecciated layers that are highly permeable and afford large yields to wells. The sedimentary materials that overlie the lava rocks form the surface of the valley plains but do not yield large quantities of ground water.

Data for the 256-sq-mi area include 133 well records, 41 well $\operatorname{logs}, 5$ chemical analyses, 5 measured sections, and a fossil list. Illustrations include a geologic cross section and maps (scale 1:63,360) showing water levels and reconnaissance geology.

Mogg, Joe L. See Reed, E. W., 52a.

Morgan, Arthur Mitchell. See Rapp, J. R., 53c.

Morrison, Roger B. See Halpenny, L. C., 47 a.

Moulder, E. A.

1953. (and Torrey, A. E., and Koopman, F. C.). Ground-water factors affecting the drainage of area IV, first division, Buffalo Rapids irrigation project, Montana: U. S. Geol. Survey Circ. 198, 46 p., 4 pls., 19 figs.

Area IV, which is situated along the west bank of the Yellowstone River about 15 miles southwest of Glendive, Montana, includes parts of three flat to gently sloping stream terraces. The water-bearing properties of the de- 
posits of the lower terrace, where waterlogging has developed, were determined by field permeability tests. Evidence is presented that leakage from the main canal is the primary cause of waterlogging. Additional recharge probably will result from the development of irrigation on a higher terrace. To intercept the recharge from these sources and to relieve the present waterlogging of the lower terrace, a drain crossing the lower terrace is recommended. Relief wells installed in the bottom of this drain would tap the principal water-bearing material and increase the effectiveness of the drain.

Data for the 4-sq-mi area include 89 well records, 85 test-hole logs, 8 chemical analyses, an aquifer test terrace gravel, 6 water-level maps, 2 cross sections, and a geologic map (scale 1:24,000).

Mower, Reed W. See also Nace, R. L., 55.

1953a. Records of wells and ground-water levels in eastern Jerome County, Idaho: U. S. Geol. Survey dupl. rept., 91 p., 1 pl., 2 figs.

Data for the 221-sq-mi area include 165 well records and 93 well logs.

1953b. Records of wells, ground-water levels, and ground-water withdrawals in the lower Goose Creek basin, Cassia County, Idaho: U. S. Geol. Survey dupl. rept., 92 p., 1 pl., 2 figs.

Data for the 470-sq-mi area include 579 well records, 66 well logs, and well-discharge measurements.

\section{Mozola, Andrew J.}

1951. The ground-water resources of Seneca County, New York: N. Y. Water Power and Control Comm. Bull. GW-26, 57 p., 4 pls., 5 figs.

Four distinct aquifers are present: (1) the Camillus shale member of the Salina formation, (2) a limestone sequence (Bertie limestone member of the Salina formation up through the Onondaga limestone), (3) Devonian shale and interbedded sandstone, and (4) glacial and alluvial deposits. Buried valleys that are mapped indicate the northward extension of the bedrock valleys of both Seneca and Cayuga Lakes. Water in the valley fill is not everywhere potable, owing to a high chloride content.

Data for the 330-sq-mi county include 307 well and 18 spring records, 40 well logs, and 42 chemical analyses. Illustrations include 2 geologic cross sections and maps (scale 1:125,000) showing the bedrock surface and bedrock geology.

Mundorff, Maurice J. See also LeGrand, H. E., 52c; Weigle, J. M., 52.

1945. Progress report on ground water in North Carolina: N. C. Div. Min. Res. Bull. 47, 78 p., 4 pls., 7 figs.

Large ground-water supplies can be obtained from Coastal Plain formations and wells yielding 500 to $1,000 \mathrm{gpm}$ are not uncommon. In the mountain and Piedmont sections, some wells in schist yield 50 to $100 \mathrm{gpm}$ and a few yield as much as $300 \mathrm{gpm}$. The other formations are generally less satisfactory as aquifers.

Problems concerning quality of water, including chloride, iron, and fluoride content as well as hardness and corrosiveness, are discussed in some detail. Data include 316 well records, 24 chemical analyses, and geologic cross sections. A map shows chloride content of ground water in the Coastal Plain, and another shows general ground-water areas in the State.

1946. Ground water in the Halifax area, North Carolina: N. C. Div. Min. Res. Bull. 51, 76 p., 6 pls., 7 figs. 
Small to moderate supplies of ground water are obtained from wells in granite and somewhat larger supplies from wells in slate, schist, and gneiss. Moderate to large supplies are obtained from Cretaceous deposits in the eastern part of the area, a few miles east of the Fall Line. The area along the Fall Zone has been one of the most difficult in which to obtain ground water because the crystalline bedrock is covered only by a thin layer of sediments.

The 2,698-sq-mi area includes Edgecombe, Halifax, Nash, Northhampton, and Wilson Counties. Data include 800 well records and 49 chemical analyses. Maps show water levels, bedrock surface, bedrock geology, and surficial geology (scale about 1:380,000).

1947a. Ground water in the Neuse River basin, North Carolina, in Hydrologic data on the Neuse River basin, 1866-1945: N. C. Div. Water Res. and Eng., p. 88-115, 3 figs.

Data for the 5,490-sq-mi area include 153 well records, 18 chemical analyses, and a geologic cross section and map (scale about 1:1,400,000).

1947b. Ground water in the Cape Fear River basin, North Carolina, in Hydrologic data on the Cape Fear River basin, 1820-1945: N. C. Div.

Water Res. and Eng., p. 126-164, 3 figs.

Of the rocks of the Piedmont area, which include granite, slate, and schist of presumed Precambrian age and sedimentary rocks of Triassic age, the schists generally yield the most ground water. In the Coastal Plain area, 5 important aquifers of sand and limestone range in age from late Cretaceous to Miocene.

Data for the 8,570-sq-mi area include 253 well records, 51 chemical analyses, a geologic cross section, and a geologic map (scale about $1: 1,400,000)$.

1947c. A possible new source of ground-water supply for the Elizabeth City area, North Carolina: N. C. Div. Min. Res. Inf. Circ. 6, 16 p., 2 figs.

A ground-water supply of better quality and larger quantity than the present supply could be obtained from sand 60-80 ft deep within a few miles of the city. Water from sand is softer, less corrosive, and has lower iron and chloride content than the present supply. Because of greater permeability of the sand, 4 or 5 wells should yield as much water as is now pumped from the 225 wells now used for public supply.

Data include 62 well records, 4 well logs, and 8 chemical analyses. A map shows an area of high chloride content.

1948a. Ground water in the Yadkin-Pee Dee River basin, North Carolina,

in Hydrologic data on the Yadkin-Pee Dee River basin, 1866-1945:

N. C. Div. Water Res. and Eng., p. 140-172, 3 figs.

In the coastal plain section of the basin, ground water is obtained in quantity from seven sand and limestone aquifers ranging in age from Late Cretaceous to Pleistocene. In the piedmont section, schist generally yields larger quantities of water than granite, slate, and gneiss.

Data for the 9,300 -sq-mi area include 195 well records and 65 chemical analyses. Maps show the geology of the piedmont section and the coastal plain section (scale about 1:1,000,000).

1948b. Geology and ground water in the Greensboro area, North Carolina:

N. C. Div. Min. Res. Bull. 55, 108 p., 14 pls., 9 figs. 
Except for a belt of sandstone and shale along the Dan River, the entire area is underlain by igneous and metamorphic rocks. Wells drilled in greenstone schist have a considerably higher average yield than wells in any other rock in the area. Well yield is related to topographic location; the average yield of wells in draws and valleys is $3 \frac{1}{2}$ times greater than that of wells drilled on hills. Draws and valleys mark the location of fractured zones saturated with water, whereas hills occupy areas of massive rock containing little water.

The 2,975-sq-mi area covers Alamance, Caswell, Forsyth, Guilford, Rockingham, and Stokes Counties. Data include 1,260 well records, 12 well logs, and 45 chemical analyses.

1949. (and LeGrand, H. E.). Ground water in the Catawba and Broad River basins, North Carolina, in Hydrologic data on the Catawba and Broad River Basins, 1872-1945: N. C. Div. Water Res. and Eng., p. 103-129, 2 figs.

Data for the 4,700-sq-mi area include 289 well records, 42 chemical analyses, and a geologic map (scale about 1:1,000,000) modified from an existing source.

1950. Flood-plain deposits of North Carolina Piedmont and mountain streams as a possible source of ground-water supply; preliminary report: N. C. Div. Min. Res. Bull. 59, 20 p., 2 figs.

Information obtained from reconnaissance studies and 21 test borings indicates that many of the flood plains are underlain by a sufficient thickness of permeable water-bearing sand and gravel to be potentially important as aquifers.

Data include logs of test holes and map of State showing flood-plain deposits.

1952. (and Reis, D. J., and Strand, J. R.). Progress report on ground water in the Columbia Basin project, Washington: U. S. Geol. Survey Wash. State Ground Water Rept. 3, 229 p., 5 pls., 17 figs.

Basalt lavas are the chief aquifers in the area, and wells in all parts of the project obtain water from them. Yields range from a fraction of a gallon to about $2,000 \mathrm{gpm}$. In general, yields show a fair correlation with depth of well drilled below the water table, the average yield being about $11 / 2 \mathrm{gpm}$ per foot of penetration below the water table. Although more than half the wells are drilled in basalt, glaciofluvial gravels are the most prolific aquifers in the area, yielding as much as $7,000 \mathrm{gpm}$ to individual wells.

The 3,900-sq-mi area lies in Grant, Adams, and Franklin Counties. Data include 602 well records, 185 well logs, and 24 chemical analyses. Maps show water levels and bedrock surface (scale about 1:150,000).

1953. Ground-water conditions in the Columbia Basin project: U. S. Geol. Survey dupl. rept., 25 p., 7 figs.

Develepment of irrigation in the Columbia Basin project in Washintgon will cause a slow rise of the water table at the start, the rate of rise accelerating as more land is placed under irrigation. The average rate of rise may be about 8 to $10 \mathrm{ft}$ per yr. Because surface drainage is poorly developed or absent in large parts of the area, lakes and swamps will eventually form at many places.

Graphical studies show relation of specific capacity to cumulative percentage of wells and relation of yield to depth of well below the water table. 
1954. (and Bodhaine, G. L.). Investigation of the rise in level of Soap Lake at Soap Lake, Washington: U. S. Geol. Survey dupl. rept., 117 p., 3 pls., 33 figs.

Data show an abnormal inflow into Soap Lake, due in part to above-normal precipitation and in part to irrigation within the area. The abnormal inflow due to irrigation in 1952-53 probably was not more than a few second-ft; but it is likely to increase in future years because a considerable part of the water applied to crops has gone into ground-water storage, gradually raising the ground-water levels and increasing the gradient toward the lake.

Maps show water levels, top basalt, and top of feldspar-bearing flow rocks (scale about 1:20,000).

1955. (and Weigle, J. M., and Holmberg, G. D.). Ground water in the Yelm area, Thurston and Pierce Counties, Washington: U. S. Geol. Survey Circ. 356, 58 p., 2 pls., 17 figs.

Abandonment of the Yelm irrigation ditch has resulted in greatly increased utilization of ground water for irrigation in the Yelm area. Of the 25,000 to 30,000 acre-ft of water discharging annually from beneath Yelm prairie, 7,000 to 8,000 acre-ft probably could be recovered through wells. This amount is more than enough to irrigate all the irrigable land on the prairie.

Data for the 218-sq-mi area include 330 well and 10 spring records, 38 well $\operatorname{logs}$, and 3 chemical analyses. Illustrations include 5 geologic cross sections and maps showing water levels, maximum extent and stages in the retreat of the Vashon ice sheet, and areal geology (scale about 1:72,000).

\section{Murphy, Leonard $M$.}

1951. Earthquake fluctuations in wells, in United States earthquakes, 1949: U. S. Coast and Geodetic Survey Serial 748, p. 31-40.

Data for seismic water-level fluctuations in 1949 are given for observation wells of the U. S. Geological Survey in Florida and New York.

1952. Fluctuations in well water levels, in United States earthquakes, 1950: U. S. Coast and Geodetic Survey Serial 755, p. 20-30.

Data for seismic water-level fluctuations in 1950 are given for observation wells of the U. S. Geological Survey in California, Florida, Illinois, Iowa, Louisiana, Michigan, New Jersey, New Mexico, New York, Ohio, Rhode Island, Tennessee, Texas, and Wisconsin.

1953. Fluctuations in well water levels, in United States earthquakes, 1951: U. S. Coast and Geodetic Survey Serial 762, p. 21-24.

Data for seismic water-level fluctuations in 1951 are given for observation wells of the U. S. Geological Survey in California, Florida, Kentucky, Michigan, Nebraska, New Jersey, New York, Tennessee, and Texas.

1954. Fluctuations in well water levels, in United States earthquakes, 1952: U. S. Coast and Geodetic Survey Serial 773, p. 51-65.

Data for seismic water-level fluctuations in 1952 are given for observation wells of the U. S. Geological Survey in Alabama, Arizona, California, Florida, Idaho, Illinois, Indiana, Iowa, Kansas, Kentucky, Louisiana, Maryland, Michigan, Montana, Nevada, New Jersey, New Mexico, New York, Oklahoma, Rhode Island, Tennessee, Texas, Utah, Washington, Wisconsin, and Hawaii.

1955. Fluctuations in well water levels, in United States earthquakes, 1953: U. S. Coast and Geodetic Survey Serial 785, p. 30-39. 
Data for seismic water-level fluctuations in 1953 are given for observation wells of the U. S. Geological Survey in Arizona, California, Florida, Idaho, Illinois, Iowa, Maryland, Michigan, Minnesota, New Jersey, New York, Tennessee, Utah, Wisconsin, and Hawaiian Islands.

Murray, C. Richard. See also Theis, C. V., 42.

1942. Preliminary report on completion of the New Mexico State Engineer

Deming test well: N. Mex. State Engineer 14th and 15th Bienn. Repts., 1939-42, p. 183-218, 2 figs. [1953].

The Deming test well was drilled to learn if sufficient water for irrigation occurs below zones currently used. The well, drilled to 1,001 ft, encountered little water below $442 \mathrm{ft}$ and ended in volcanic rock and ash.

Data include drillers log, sample log, water-level measurements, an aquifer test, and a chronological description of drilling operations.

Nace, Raymond L. See also Jeffords, R. M., 46; Stewart, J. W., 54.

1948. Preliminary report on ground water in Minidoka County, Idaho, with special reference to the North Side pumping division of the Minidoka project: U. S. 81st Cong., 2 d sess., H. Doc. 721 , p. 157-207, 4 figs., 1950.

The chief aquifer is the Snake River basalt. The amount of ground water that can be withdrawn perennially from wells in the North Side pumping division appears to be limited only by the ability of the lava aquifers to transmit water from the regional body of ground water in the Snake River Plain to the areas of local withdrawal. Aquifer tests indicate that irrigation wells can be pumped at rates in excess of $2,100 \mathrm{gpm}$ each, with small or negligible drawdowns.

Data for the 750-sq-mi area include 93 well records, 13 test-hole logs, 30 well logs, 30 chemical analyses, and a water-level map.

1950. (and Fader, S. W.). Records of wells on Rathdrum Prairie, Bonner and Kootenai Counties, northern Idaho: U. S. Geol. Survey dupl. rept., 49 p., 1 pl., 1 fig.

Data for the 270-sq-mi area consist of 150 well records and 14 well logs.

1953. Ground water for irrigation in Box Butte County, Nebraska, with a section on chemical quality of the water by W. H. Durum: U. S. Geol. Survey Circ. 166, 39 p., 1 pl., 5 figs.

An investigation of the ground-water resources of Box Butte County, Nebraska, made in 1938 by Cady and Scherer (Water-Supply Paper 969) showed only 13 wells used for irrigation. The number of irrigation wells had increased to 76 in 1946, when about 9,000 acres was irrigated with ground water. Nevertheless, the increased pumpage caused only inconsequential net changes in water levels, if reasonable allowance is made for natural seasonal fluctuations of the water table. The yields of the irrigation wells range from 150 to $3,500 \mathrm{gpm}$. The withdrawal of ground water in 1946 was less than one-third the estimated annual recharge from precipitation, and the pumped water was salvaged ground water that otherwise would have been lost from the county by underflow, evapotranspiration, or discharge into streams. The ground water is moderately mineralized and hard but it is generally satisfactory for domestic use, and is good to excellent for irrigation.

Data for the 1,066-sq-mi county include 117 well records, 20 well logs, 
periodic water-level measurements, a water-level map, and 12 chemical analyses.

1955. (and West, S. W., and Mower, R. W.). Feasibility of groundwater features of the Alternate Plan for the Mountain Home project, Idaho, abstract and summary: U. S. Geol. Survey dupl. rept., 24 p.; constitutes summary and conclusions from Water-Supply Paper 1376 (in preparation).

Unresolved major problems that concern the feasibility of the alternate plan are of three types: (1) amount of ground water that must be pumped to replace surface water and irrigation-return water; (2) amount of ground water that is perennially available and accessible; and (3) chemical suitability of the ground water and the water-management practices necessary to forestall an unfavorable salt balance.

Naftel, W. L. See Doyel, W. W., 54.

Neill, Robert $M$.

1955. Basic data of the 1946-47 study of the ground-water resources of Brevard County, Florida: U. S. Geol. Survey dupl. rept., 45 p., 5 figs.

Data for the 1,032-sq-mi county include 796 well records, a geologic cross section, and maps showing chloride content, water levels, and top of the Eocene limestones.

Nelson, W. B. See also Fix, P. F., 50; Thomas, H. E., 48, 52e.

1953. (and Thomas, H. E.). Pumping from wells on the floor of the Sevier Desert, Utah: Am. Geophys. Union Trans., v. 34, no. 1, p. 7484,4 figs.

This paper describes the development and subsequent disappearance of a cone of depression caused by pumping from pre-Lake Bonneville deposits at the Topaz Relocation Center. Because the water table is near the surface, evapotranspiration is large and "alkali" is deposited in the waterlogged soil.

1954. Pumping costs in southwestern Utah, in Progress report on selected ground-water basins in Utah: Utah State Engineer Tech. Pub. 9, p. 95-104, 4 figs.

This report is restricted to comparison of operating costs of pumping water with electric pumps in two Utah areas. Figures show that costs are related to both pumping lifts and efficiency of pump installations.

Newcomb, Reuben C. See also Meyers, J. D., 52.

1951a. Ground-water situation in Oregon: U. S. Geol. Survey dupl. rept., 19 p., 1 pl., 5 figs.

The varied climate, geology, and topography of Oregon cause groundwater conditions to vary in the separate physiographic areas of the State. Ground-water supplies range from very small in areas of poorly permeable sedimentary and metamorphic rocks to large in areas of coarse alluvium and fragmental lava rocks. In general, the water is of good chemical and physical quality. The largest use of ground water is for irrigation. The ground-water resources of the State are not yet fully developed.

1951b. Preliminary report on the ground-water resources of the Walla Walla Basin, Washington-Oregon: U. S. Geol. Survey dupl. rept., 203 p., 35 pls. 
The chief aquifers are the Columbia River basalt, which underlies the whole basin, and old gravels of Pleistocene age, which underlie the valley floor from the mouths of mountain canyons downstream beyond the town of College Place. Water is withdrawn from the gravel aquifers at nearly the maximum rate possible without depletion of adjacent surface water. The basalt aquifer can yield much more water than is now developed. Fault zones and areas of severe deformation should be avoided as well locations, for they act as barriers to lateral movement of ground water.

Data for the 1,330-sq-mi basin include 538 well and 44 spring records, 106 well logs, and 23 chemical analyses. Illustrations include 2 geologic cross sections and maps (scale about 1:95,000) showing the top of the basalt and areal geology.

1952. Ground-water resources of Snohomish County, Washington: U. S. Geol. Survey Water-Supply Paper 1135, 133 p., 2 pls., 19 figs.

The Esperance sand member, an advance outwash unit of the Vashon drift, is the most widespread and important aquifer. In the river valleys ground water occurs in the alluvial deposits beneath the valley flood plains, in the outwash gravels that line the sides of many of the valleys, and in strata below the till where those strata pass beneath the valley-fill materials.

Data for the 1,000-sq-mi county include 690 well records, 119 well logs, 10 measured sections, water-level data, 12 chemical analyses, and a map showing water levels and geology (scale 1:62,500).

1953. (and others). Seismic cross sections across the Spokane River valley and the Hillyard Trough, Idaho and Washington: U. S. Geol. Survey dupl. rept., 16 p., 18 pls.

Two cross sections based on refraction profiles yielded data on the position of the water table, the base of the glacial and glaciofluvial deposits, and the buried bedrock surface.

Newcome, Roy, Jr.

1954. Structure-contour map on top of the Knox dolomite in middle Tennessee: Tenn. Div. Geology Ground-Water Inv. Prelim. Chart 5; scale 1:500,000; contour interval, $100 \mathrm{ft}$.

The area mapped extends from the northward-flowing section of the Tennessee River east to the western escarpment of the Cumberland Plateau.

Noecker, Max.

1954. (and Greenman, D. W., and Beamer, N. H.). Water resources of the Pittsburgh area, Pennsylvania: U. S. Geol. Survey Circ. 315, 56 p., 2 pls., 37 figs.

In $1951,3,040 \mathrm{mgd}$ of water was used in the area but much larger quantities can be developed. The water-bearing properties of the geologic formations are described. Maps show the location of the permeable valley-fill deposits, bedrock surface in the Triangle area, and water levels in the Triangle area. Tables and graphs show the chemical quality and temperature of water from ground and surface sources. Laws affecting the use of water in the area are described briefly and the water-resources potential is evaluated.

Norris, Stanley E. See also Cross, W. P., 52.

1948a. The water resources of Montgomery County, Ohio, with sections on climate and surface-water resources by W. P. Cross, and on glacial geology by R. P. Goldthwait: Ohio Water Res. Board Bull. 12, 83 p., 51 pls. 
The chief aquifers are glacial-outwash gravels in the Mad and Miami River valleys. Generally good water supplies are available from formations of Silurian age, well yields ranging from 6 to $200 \mathrm{gpm}$. Rocks of Late Ordovician age yield little or no water. Limestone underlying shale of Late Ordovician age yields salt water. More ground water $(90 \mathrm{mgd})$ is used in Montgomery County than in any other county of the State.

Data for the 465 -sq-mi county include 50 well records, 522 graphic logs, 27 chemical analyses, and 3 geologic cross sections. Maps show preglacial and interglacial valleys (scale about $1: 240,000$ ), bedrock surface, bedrock geology, and surficial geology (scale 1:62,500).

1948b. The bedrock surface and former drainage systems of Montgomery County, Ohio: Ohio Jour. Sci., v. 48, no. 4, p. 146-150, 1 pl.

A map showing the bedrock surface has a scale of about $1: 300,000$ and a contour interval of $100 \mathrm{ft}$. For a similar map at a larger scale and with 50-ft contours, see Norris $48 \mathrm{a}$.

1949. Measuring the length of casing in drilled water wells: Johnson Natl. Drillers Jour., v. 21, no. 2, p. 6-7, 1 fig.

Describes a magnetic device for measuring casing length in drilled wells.

1950. The water resources of Greene County, Ohio, with sections on surface-water resources by W. P. Cross and on Wisconsin glacial deposits by R. P. Goldthwait: Ohio Div. Water Bull. 19, 52 p., 23 pls.

Thick, permeable glacial gravels in the valleys of the Mad and Little Miami Rivers are excellent aquifers.

Data for the 416-sq-mi county include 1,200 well records, 5 well logs, 127 graphic well logs, and 25 chemical analyses. Illustrations include 3 geologic cross sections and maps showing ground-water areas, bedrock geology and bedrock surface (scale 1:62,500), surficial geology, stages in glacial history, and principal buried valleys (scale about 1:125,000).

1951. The bedrock surface and the distribution of the consolidated rocks in Montgomery, Greene, Clark, and Madison Counties, Ohio: Ohio Jour. Sci., v. 51, no. 1, p. 13-15, 1 fig.

The floors of the buried valleys in west-central Ohio were eroded to an altitude of about $500 \mathrm{ft}$ above sea level before the valleys were filled with glacial drift. The present altitude of the land surface in parts of Clark and Madison Counties is more than $1,100 \mathrm{ft}$ above sea level. The greatest known thickness of drift is near London, where a well $520 \mathrm{ft}$ deep failed to reach bedrock. In areas of former drainage divides, bedrock occurs at altitudes more than $1,000 \mathrm{ft}$ above sea level. Preglacial relief, therefore, was about $500 \mathrm{ft}$, much more than present relief. A geologic map (scale about 1:625,000) shows distribution of consolidated rocks in the area.

1952a. Electric tape for measuring water levels in wells: Johnson Natl. Drillers Jour., v. 24, no. 6, p. 7, 11, 2 figs.

Describes an electric tape suitable for making frequent instantaneous measurements of depth to water in wells. No battery is required, the current coming from galvanic action between the steel tape and a magnesium tip.

1952b. (and Cross, W. P., Goldthwait, R. P., and Sanderson, E. E.). The water resources of Clark County, Ohio: Ohio Div. Water Bull. 22, 82 p., 29 pls.

The chief aquifer is glacial gravel in the Mad River valley; the deposits 
probably are capable of furnishing enough water to meet the water-supply needs of Springfield. Rocks of Silurian age generally yield supplies adequate for farm and domestic requirements.

Data for the 402-sq-mi county include 900 well records, 154 graphic well logs, and 12 chemical analyses. Maps show pre-Wisconsin valleys, groundwater areas, surficial geology, bedrock surface, and bedrock geology (scale $1: 62,500)$.

1954. Importance of ground-water studies to highway engineering: Ohio State Univ. Dept. Civil Eng., Highway Eng., 5th Ann. Symposium Proc., p. 35-40.

Reviews ground-water publications and data that may be of help to highway engineers.

O'Connor, H. G.

1951. Ground-water resources of Chase County, in Geology, mineral resources, and ground-water resources of Chase County, Kansas: Kans. Geol. Survey, v. 11, pt. 3, p. 28-48, pls. 3 and 6, fig. 3.

Aquifers include Permian limestones and Quaternary alluvium, but nowhere in the county can large supplies of ground water be developed.

Data for the 774-sq-mi county include 225 well records and 34 chemical analyses. Illustrations include 5 geologic cross sections, a map of groundwater areas, and an areal geologic map (scale 1:63,360).

1953. Ground-water resources of Lyon County, in Geology, mineral resources, and ground-water resources of Lyon County, Kansas: Kans. Geol. Survey, v. 12, pt. 3, p. 35-59, pl. 3.

Lyon County is subdivided into 5 ground-water regions based on the dominant aquifer of each: (1) alluvium, (2) Pleistocene terrace deposits, (3) Permian rocks of the Chase and Council Grove groups (essentially limestones), (4) sandstone zones in shales of the Admire and Wabaunsee groups of early Permian and late Pennsylvanian age, and (5) Pennsylvanian rocks of the upper part of the Shawnee group. Wells in alluvium generally have the largest yields, best ehemical quality, and greatest reliability during drought periods.

Data for the 852-sq-mi county include 150 well records, 31 test-hole logs, and 36 chemical analyses. Illustrations include 5 geologic cross sections, a map of ground-water areas, and an areal geologic map (scale 1:63,360).

1955. Ground-water resources of Osage County, in Geology, mineral resources, and ground-water resources of Osage County, Kansas: Kans. Geol. Survey, v. 13, pt. 3, p. 28-50, pls. 1 and 3 .

The county is divided into four ground-water regions: valley areas where the chief aquifer is alluvium, a region where thin sandstones of the Admire and Wabaunsee groups are water bearing, a region where fractures in limestones and beds of sandstone in the Shawnee group are the main aquifers, and a region where the Ireland sandstone member of the Lawrence shale is the main aquifer.

Data for the 721-sq-mi county include 171 well records, 15 test-hole logs, and 33 chemical analyses. Maps show ground-water areas (scale about 1:85,000) and areal geology (scale 1:63,360).

Olmsted, Franklin H. See also Davis, G. H., 52; Poland, J. F., 51.

1953. Geologic features and water resources of Campo, Mesa Grande, 
La Jolla, and Pauma Indian Reservation, San Diego County, Cali-

fornia: U. S. Geol. Survey dupl. rept., 129 p., 5 pls., 2 figs.

Ground water in crystalline rocks is discussed. Schist and the schistquartz diorite complex are the best aquifers in unweathered rock, and tonalite and gabbro are good aquifers where weathered. Yields of wells in bedrock average only 1 to 2 percent of those of wells in alluvium.

Data include 19 well records, 40 spring records, 6 well logs, 12 chemical analyses, and a geologic map (scale 1:24,000) for each of the reservations.

\section{Onellion, Frank E.}

1955. (and Criner, J. H., Jr.). Ground-water resources of Chicot County, Arkansas: Ark. Geol. and Conserv. Comm. Water Res. Circ. 3, 27 p., 8 figs.

Deposits of Quaternary age between the land surface and depths generally less than $150 \mathrm{ft}$ are the chief aquifer. Locally in T. $18 \mathrm{~S}$., R. $3 \mathrm{~W}$., the water is too salty for most uses. Elsewhere the water is moderately mineralized, hard, and contains much iron. Ground-water use is $12 \mathrm{mgd}$. The Cockfield formation in the north yields at present a total of about $0.5 \mathrm{mgd}$.

Data for the $647-\mathrm{sq}-\mathrm{mi}$ county include 60 well records, 17 well $\operatorname{logs}, 48$ chemical analyses, data for aquifer tests of sands of Claiborne age and Quaternary deposits, and 2 geologic cross sections.

Otton, Edward G. See also McGuinness, C. L., 49; Rothrock, E. P., 47. 1948a. Ground-water supplies of the Campbellsville area, Kentucky: Ky. Geol. Div., dupl. rept., 39 p., 2 figs.

The chief aquifer is the Harrodsburg limestone. Ground water occurs in it along bedding planes and in tubular openings. The ground-water resources are largely undeveloped, but large supplies are not available. Wells deeper than 150 to $200 \mathrm{ft}$ yield highly mineralized water.

Data for the 60-sq-mi area include 118 well and 19 spring records, 10 well logs, 10 partial chemical analyses, and a map of ground-water areas.

1948b. Ground-water resources of the Elizabethtown area, Kentucky: Ky. Geol. Div. dupl. rept., 27 p., 4 figs.

An anticline north of Elizabethtown brings shaly layers of the Warsaw limestone to the surface and causes difficulty in obtaining ground-water supplies. Elsewhere the St. Louis limestone yields moderate supplies of ground water to wells intersecting solution channels.

Data for the 27-sq-mi area include 53 well and 7 spring records, 4 well logs, 7 chemical analyses, 5 measured sections, pumpage figures, a map of ground-water areas, and a reconnaissance geologic map (scale about 1:50,000).

1948c. Geology and ground-water resources of the London area, Kentucky: Ky. Geol. Div. dupl. rept., 47 p., 5 figs.

The chief aquifers are the Corbin and Rockcastle sandstone members of the Lee formation. Well yields range from 5 to $100 \mathrm{gpm}$ and depend on the number of joints and bedding planes that are intersected. The underlying limestones yield small quantities of highly mineralized water.

Data for the 55-sq-mi area include 99 well records, 6 well $\operatorname{logs}$, and 15 partial chemical analyses. Illustrations include a geologic cross section and a reconnaissance geologic map (scale about 1:55,000) modified from an existing source. 
1955. Ground-water resources of the southern Maryland Coastal Plain: Md. Dept. Geology, Mines and Water Res. Bull. 15, 347 p., 15 pls., 26 figs.

Most of the basic data in this report are from published reports describing ground-water conditions in the five individual counties. This summary report in addition contains analyses of aquifer-test data and reclassification of marine formations based on foraminiferal studies by Glenn G. Collins. The chief aquifers are the Patuxent, Patapsco, Raritan, and Magothy formations of Cretaceous age. The yields of wells in sand and gravel beds in these formations are, in a few localities, greater than $1,000 \mathrm{gpm}$. The Aquia greensand and the Nanjemoy formation of Eocene age are the chief aquifers in Calvert and St. Marys Counties, but yields of wells are seldom more than $400 \mathrm{gpm}$.

The report area of $1,900 \mathrm{sq} \mathrm{mi}$ comprises the 5 counties of Anne Arundel, Prince Georges, Calvert, Charles, and St. Marys. Data include 646 well records, 27 test-hole $\operatorname{logs}, 56$ well $\operatorname{logs}, 280$ chemical analyses, macro- and microfossil lists (including a 28-page table showing distribution of Foraminifera in well cuttings), and heavy-mineral studies. Tables give yields and specific capacities of wells in crystalline rocks and the Patuxent formation, Patapsco and Raritan formations, Magothy formation, Aquia greensand, Nanjemoy formation, and Piney Point formation. Aquifer-test results are given for the Patuxent formation, Patapsco and Raritan formations, Magothy formation, and Aquia greensand. Histograms show water quality in percent reacting values. Maps show the tops of the sand of the Magothy formation and the Aquia greensand, the base of the Miocene series, and the artesian head and outcrop area of the Patuxent formation, Patapsco and Raritan formations, Aquia greensand, and Nanjemoy formation.

Outlaw, Donald E.

1952. (and others). Winter Garden district, Dimmit and Zavala Counties and eastern Maverick County, Texas; records of wells, drillers' logs, water anaylses, and map showing locations of wells: Tex. Board Water Engineers Bull. 5203, 157 p., 1 pl.

The bulletin, consisting entirely of tabular data, contains 1,196 well records, 82 well $\operatorname{logs}, 177$ chemical analyses, and records of water levels in 46 wells that show the rate of decline for about 18 years. A map (scale about $1: 160,000)$ shows the outcrop of and structure contours on the Carrizo sand.

\section{Overbeck, Robert $M$.}

1948. Ground-water resources, in The physical features of Charles County: Md. Dept. Geology, Mines and Water Res., p. 138-184, pl. 8, figs. 11-18.

The chief aquifers are the Aquia greensand and the Nanjemoy formation.

Data for the 460-sq-mi county include 204 well records, test-hole logs, 20 well $\operatorname{logs}, 8$ chemical analyses, and specific-capacity figures. Illustrations include 4 geologic cross sections and maps showing the base and thickness of the Aquia formation, base and thickness of the Nanjemoy formation, and base of the Calvert formation.

1951. The ground-water resources of Calvert County, in The Water resources of Calvert County: Md. Dept. Geology, Mines, and Water Res. Bull. 8, p. 4-95, 3 pls., 5 figs.

The source of most ground water in the northeastern and eastern parts of 
the county is the Nanjemoy formation. The chief aquifers in the southern part are the Nanjemoy formation and sands of Jackson age. In the northern and western parts of the county, and for a few wells in the southern part, the Aquia greensand forms a major aquifer.

Data for the 217-sq-mi county include 212 well records, 18 test-hole logs, 52 well logs, and 11 chemical analyses. Illustrations include 3 geologic cross sections, and maps showing the base of the Calvert formation and top of the Aquia greensand.

1954. Ground-water resources, in Geology and water resources of Garrett County: Md. Dept. Geology, Mines and Water Res. Bull 13, p. 117254, pl. 8, figs. 10-21.

The geologic formations range in age from Devonian to Recent and vary widely in their hydrologic properties. Average specific capacities of wells in the various aquifers range from 0.4 in the Jennings formation to 1.5 $\mathrm{gpm}$ per $\mathrm{ft}$ of drawdown in the lower member of the Conemaugh formation.

Data for the 664-sq-mi county include 374 well and 116 spring records, 3 test-hole $\operatorname{logs}, 264$ well $\operatorname{logs}$, and 4 comprehensive chemical analyses.

Oza, M. M. See Taylor, G. C., Jr., 54.

Palmquist, W. N., Jr.

1953. (and Hall, F. R.). Public and industrial water supplies of the Blue Grass region, Kentucky: U. S. Geol. Survey Circ. 299, 101 p., 2 pls., 3 figs.

Yields of several hundred gallons per minute can be obtained from most wells in the alluvium of the Ohio Valley, whereas few of the wells in bedrock away from the river yield more than $100 \mathrm{gpm}$. The chief water-bearing materials are the unconsolidated alluvial deposits and limestone beds of Ordovician and Silurian age.

Included in the report are two maps which show graphically the source and amount of water pumped at each location and the chemical character of the water. Tables give detailed information on the 105 supplies inventoried and 49 chemical analyses. A generalized section shows the geologic formations present in the area and their water-bearing characteristics.

Parker, Garald G. See also Warren, M. A., 55.

1946. Municipal water supply of southern Florida: Soil Sci. Soc. Fla. Proc., v. 8, p. $72-88,3$ figs.

Reviews problems of developing and maintaining municipal water supplies in southern Florida.

Data include pumpage figures and 19 chemical analyses of raw ground water used in municipal supplies of southern Florida.

1948. Geology and ground water of the Everglades region, in Soils, geology, and water control in the Everglades region: Fla. Univ. Agr. Expt. Sta. Bull. 442, p. 21-42, figs. 4-14.

Reviews the geologic and ground-water relations in the Everglades region in southern Florida.

Data include 2 geologic cross sections, a map of the Pliocene surface, and a map of the areal geology (scale about 1:1,500,000).

1949. Ground-water situation of the United States: Soil Conserv., v. 15, no. 3 (October), p. 53-58, 4 figs. 
Briefly reviews principles of ground-water occurrence, methods of investigation, and ground-water problems of several areas.

A map of the United States shows areas of heavy ground-water withdrawal, areas for which considerable ground-water data are available, and (by W. F. Conyton) estimated ground-water use by States in 1945 .

1950. (and Stringfield, V. T.). Effects of earthquakes, trains, tides, winds, and atmospheric-pressure changes on water in the geologic formations of southern Florida: Econ. Geology, v. 45, no. 5, p. 441460,5 figs.

Water-level fluctuations in wells are a resultant of several factors: changes in recharge and discharge, tides, atmospheric pressure, winds, earthquakes, and loads such as passing trains. Characteristically, artesian aquifers respond to these forces in a manner different from that of nonartesian aquifers, but in some places local geologic conditions in a nonartesian aquifer may cause water-level fluctuations that would ordinarily be found only in artesian wells.

1951. Geologic and hydrologic factors in the perennial yield of the Biscayne aquifer: Am. Water Works Assoc. Jour., v. 43, no. 10, p. 817834, 7 figs.

A general overall view is presented of the geology and hydrology basic to water-supply developments in the Miami area. Factors in the perennial yield of the Biscayne aquifer are discussed.

1955a. Salt-water encroachment in Florida, in Water management in Florida: Fla. Eng. and Indus. Expt. Sta. Bull. ser. 72, v. 9, no. 4, p. $42-45$.

States conclusions from investigations of salt-water encroachment made in Florida and California. Indicates that molecular diffusion in the salt waterfresh water interface is a much more potent force than has been previously considered, and of itself diffusion tends to dissipate the encroaching wedge of salt water in a fresh-water aquifer; that tidal pull and thrust likewise is a causative factor in widening and thickening the interface zone; and that fresh-water flow over the salt-water wedge tends to "erode" the wedge by sweeping away diffused and tidally-mixed saline water of the interface zone.

Warns of complacency or carelessness in the handling of future watermanagement problems in coastal areas where salt-water problems are prime factors.

1955b. The encroachment of salt water into fresh, in Water: U. S. Dept. Agriculture Yearbook 1955, p. 615-635, 5 figs.

The relations between salt water and fresh water and the general mechanics of salt-water encroachment are described for both ground-water and surface-water bodies. Typical cases of sea-water encroachment in the Miami and Baltimore areas are discussed. There is a further discussion of the encroachment of connate water, saline water residual from Pleistocene seas, juvenile waters, irrigation water in which the dissolved solids have been concentrated by evaporation and, among others, the waste waters from mining, industrial, and petroleum operations. Specific details of salt-water encroachment are given for most of the States.

1955c. (and Brown, R. H., Bogart, D. B., and Love, S. K.). Salt-water encroachment, in Water resources of southeastern Florida, with special 
reference to the geology and ground water of the Miami area: U. S. Geol. Survey Water-Supply Paper 1255, p. 571-711, figs. 163-201.

The Atlantic Ocean and Biscayne Bay are the source of salt-water contamination of ground and surface waters in the Miami area. The salt water enters through canals and through the permeable rocks of the Biscayne aquifer.

Data include chloride determinations of water samples from Biscayne Bay, chemical composition of salt-contaminated waters, and numerous maps of chloride distribution and patterns of encroachment. Encroachment in the Miami area, rates of movement of encroaching bodies of salt water, and effects of rainfall, pumping, and other factors on the isochlor pattern are reviewed. A method is given for adjusting measurements of water-table elevations for wells tapping water of different densities. Computations give the order of magnitude of the maximum amount of salt-water movement inland that could occur during the time between low tide and the following high tide.

Conclusion is drawn that salt-water encroachment in this area can be controlled by proper placement and use of water-control structures in the canals as near Biscayne Bay as possible in order to: (1) raise water levels upstream from the dam and in the adjacent aquifer; and (2) prevent incursion of salt water from the Bay in the upstream reaches of the canals.

1955d. (and Hoy, N. D., and Schroeder, M. C.). Geology and geomorphology, in Water resources of southeastern Florida, with special reference to the geology and ground water of the Miami area: U. S. Geol. Survey Water-Supply Paper 1255, p. 57-155, pls. 4-24, figs. 8-28.

The geologic factors pertinent to the occurrence, movement, replenishment, and discharge of ground and surface waters in southern Florida are discussed. Particular attention is given to the late Tertiary geologic section (Post-Miocene), with both detailed and generalized information on the geologic structure, stratigraphy, paleontology, geomorphology, and geologic history of the area. The Silver Bluff terrace is described and mapped for the first time. Pleistocene landscape and related marine features are described and the more important ones, such as bays, peninsulas, and islands, are named. Geologic maps, stratigraphic sections, a map of the bedrock surface under the Everglades, and a map of the Pleistocene terraces are some of the illustrations.

The effects of solution, erosion, fluctuating sea level, shoreline processes, climate and vegetation, and other related factors are discussed in accounting for the present geology and geomorphology, and for interpreting the geologic history of the area.

1955e. (and Warren, M. A.). Ground water, in Water resources of southeastern Florida, with special reference to the geology and ground water of the Miami area: U. S. Geol. Survey Water-Supply Paper 1255, p. 157-290, pls. 14-16 and 19-24, figs. 30-83.

Ground water occurrence is described by areas, and within areas by aquifers. New names for geohydrologic units are proposed and descriptions given for the Biscayne aquifer, the Floridan aquifer, and the Floridan aquiclude. Data are given for quantitative studies of the aquifers, including descriptive text and pictorial, graphical, and tabular material. Watertable and piezometric surface maps are given for a number of areas, and pumping tests and pumping test procedures are described.

Among other things, graphs show relation of total annual water-level 
recharge to precipitation, rate of water-table decline to stage as correlated with evaporation rate, and estimated evapotranspiration salvage that might be achieved by lowering of the water table.

It is concluded that the Biscayne aquifer at Miami compares favorably in productivity with any aquifer in the world.

\section{Paulsen, Carl G.}

1948. Water investigations of the Geological Survey in the United States, with special reference to ground-water conditions: Assoc. Western State Engineers 21st Ann. Conv. Proc., p. 74-85.

The major problem is to find out what conditions are before developments are installed, to insure against failures due to local overdevelopment, and to permit the most efficient and economical use of the water.

Paulson, Quentin F.

1951. Ground water in the Neche area, Pembina County, North Dakota:

U. S. Geol. Survey N. Dak. Ground-Water Studies 16, 37 p., 4 figs.

Sands in the alluvial deposits of the Pembina Valley may yield sufficient water for the village of Neche and for small industries. Paleozoic rocks underlying the area yield highly mineralized water.

Data for the 90 -sq-mi area include 173 well records, 18 test-hole logs, 7 chemical analyses, 3 cross sections, and a water-level map.

1952. Geology and occurrence of ground water in the Streeter area, Stutsman, Logan, and Kidder Counties, North Dakota: U. S. Geol. Survey N. Dak. Ground-Water Studies 20, 73 p., 14 figs.

Glacial-outwash deposits cover about $30 \mathrm{sq} \mathrm{mi}$ west and southwest of Streeter and constitute the most important aquifer in the area. Where penetrated by test drilling, the deposits are unusually coarse and relatively free of clay and silt. The average saturated thickness is estimated to be not less than $20 \mathrm{ft}$ and the amount of water stored in them is estimated to be not less than 75,000 acre-ft. Conditions are favorable for substantial annual recharge from precipitation. The water in the outwash deposits is hard but the mineral content is only moderate.

Data for the 216-sq-mi area include 318 well records, 19 test-hole logs, 11 chemical analyses, 5 cross sections, and a geologic map (scale about 1:70,000).

1953. Ground water in the Fairmount area, Richland County, North Dakota, and adjacent areas in Minnesota: U. S. Geol. Survey N. Dak. Ground-Water Studies 22, 67 p., 2 pl., 2 figs.

The Dakota sandstone underlies most of the area, except southeast of Fairmount, at depths ranging between 200 and $280 \mathrm{ft}$. It consists mainly of fine sand ranging in thickness from 5 to $15 \mathrm{ft}$. Because the sand is so fine grained, it will not yield water in large quantities to any single well. The water is highly mineralized. Another important aquifer occurs mainly southeast of Fairmount in the glacial drift at depths ranging from 90 to $120 \mathrm{ft}$.

Data for the 72-sq-mi area include 148 well records, 19 logs of test holes and wells, 8 chemical analyses, 2 cross sections, and an aquifer map (scale $1: 62,500)$.

1955. Geology and occurrence of ground water in the Stanley area, Mountrail County, North Dakota: U. S. Geol. Survey N. Dak. GroundWater Studies 23, 59 p., 3 pls., 2 figs. 
Moderate quantities of ground water of reasonably good quality are available at shallow depths from deposits of sand and gravel in the valley of the Little Knife River. Conditions are favorable for induced recharge if large withdrawals should be made. Elsewhere in the area, ground-water resources are either in short supply or of poor quality.

Data for the 72 -sq-mi area include 116 well records, 46 test-hole logs, and 10 chemical analyses. Illustrations include geologic cross sections and a geologic map (scale about $1: 48,000$ ).

Peden, G. H. See Reed, E. W., 52a.

\section{Peek, Harry M.}

1951. Cessation of flow of Kissengen Spring in Polk County, Florida: Fla. Geol. Survey Rept. Inv. 7, p. 73-82, 5 figs.

In February 1950 Kissengen Spring became the only major artesian spring to have ceased flowing. This was the result of pumping by wells, which diverted the water formerly discharged through the spring.

Water levels in the principal artesian aquifer are shown for 1949.

1953. The artesian water of the Ruskin area of Hillsborough County, Florida; Interim report: Fla. Geol. Survey Inf. Circ. 4, 22 p., 7 figs.

Locally, artesian pressures are lowered as much as $8 \mathrm{ft}$ during periods of heaviest withdrawal. The resulting cone of depression may cause salt-water encroachment, either by sea water or by salty water from deeper formations.

Maps show water levels and distribution of chloride.

1955. (and Anders, R. B.). Interim report on the ground-water resources of Manatee County, Florida: Fla. Geol. Survey Inf. Circ. 6, 38 p., 10 figs.

Unconfined water occurs in surficial deposits of sand and limestone and is the source of many domestic supplies. Confined water occurs in thick limestones of Eocene, Oligocene, and Miocene age. A deep-well current meter was used to determine the depth, thickness, and relative productivity of permeable zones in the limestone aquifer.

Maps for the 800-sq-mi county show water levels, area of artesian flow, and distribution of chloride.

Perlmutter, Nathaniel M. See also de Laguna, Wallace, $49 \mathrm{~b}$.

1949. Geologic correlation of logs of wells in Long Island, in Suter, Russell, Mapping of geologic formations and aquifers of Long Island, New York: N. Y. Water Power and Control Comm. Bull. GW-18, p. 3-24.

This report deals with the distribution, geologic structure, and thickness of the unconsolidated deposits on Long Island. It also contains information as to areas of recharge of the various aquifers, the nature of the various confining beds, and the physical properties of the sediments of which the aquifers are composed.

1953. (and Arnow, Ted). Ground water in Bronx, New York, and Richmond Counties, with summary data on Kings and Queens Counties, New York City, New York: N. Y. Water Power and Control Comm. Bull. GW-32, 86 p., 5 pls., 11 figs.

Ground water represents only about 8 to 13 percent of the more than $1,000 \mathrm{mgd}$ of water consumed daily in New York City. In Bronx, Manhattan, and Richmond Counties, most ground water is obtained from Pleistocene 
sand and gravel. The most prolific bedrock aquifer is the Inwood limestone in Bronx County. The Manhattan schist underlying New York County yields a little water.

Data for the 145-sq-mi area include 240 well records, 82 well logs, 69 chemical analyses, and 5 cross sections. Maps show the bedrock surface of New York County (scale about 1:96,000), the pre-Pleistocene formations in New York City (scale 1:125,000), and the Pleistocene deposits in New York City (scale 1:125,000), all adapted from existing sources.

Peterson, Carl G. B.

1947. Ground-water investigations in the Mobile area, Alabama: Ala. Geol. Survey Bull. 58, 32 p., 1 pl., 3 figs.

Pumping from the shallow aquifer in the area has had to be reduced, owing to salt-water encroachment, but the decrease in pumping is an aid to flushing the salt water from the aquifer. Deep aquifers may be used as an additional source of large supply.

Data include 35 shallow- and 13 deep-well records and 11 chemical analyses.

Petitt, Ben M.

1955. (and Winslow, A. G.). Geology and ground-water resources of Galveston County, Texas: Tex. Board Water Engineers Bull. 5502, 219 p., 3 pls., 33 figs.

Chief aquifers are sands in the Beaumont clay. Salt-water encroachment has been a problem in the county for many years; lowering of artesian pressure in the Alta Loma and Texas City areas has brought encroachment either from below or from downdip. Subsidence of the land surface has occurred in a large part of the county and is probably the result of withdrawal of ground water. Much additional ground water is available from both the so-called Alta Loma sand and the upper part of the Beaumont clay, but development should be preceded by exploration and study. Salt-water relations and flushing of aquifers are discussed.

Data for the $430 \mathrm{sq} \mathrm{mi}$ of land in the county include 474 well records, 135 well logs, 2 geologic cross sections, pumpage figures, and 1,017 chemical analyses of water from 314 wells. Results are given for aquifer tests of the so-called Alta Loma sand in the Alta Loma area and the sand of the Beaumont clay in the Texas City area. Maps show the top and thickness of, and water levels in, the so-called Alta Loma sand.

Phoenix, David A. See also Loeltz, O. J., 49, 55; Robinson, T. W., 48.

1948. Geology and ground water in the Meadow Valley Wash drainage area, Nevada, above the vicinity of Caliente: Nev. State Engineer Water Res. Bull. 7, 117 p., 5 pls., 1 fig.

Large ground-water developments are limited to alluvial sediments beneath the floors of valleys. Much water lost by evaporation and transpiration can be recovered by pumping.

Data for the 2,000-sq-mi area include 127 well records, 54 well $\operatorname{logs}, 17$ chemical analyses, a geologic cross section, and an areal geologic map (scale $1: 31,680)$.

\section{Piper, Arthur M.}

1948. Runoff from rain and snow; a review of concepts and principles with relation to forecasting seasonal water supplies, and particularly to the effects of ground water: Am. Geophys. Union Trans., v. 29, no. 4, p. 511-520, 2 figs. 
The basic principles of the idealized hydrologic cycle are reviewed, with emphasis on storage and movement of water in the soil. A distinction is made between ground-water runoff and overland runoff in terms of storage and lag, expressed as accumulated deviations from uniform flow over a period of several years. These functions are presented for the period 1920 through 1945 for three rivers in central Oregon: the John Day, Deschutes, and Metolius, which exemplify minimum, moderate, and maximum effects, respectively, of storage and lag. The Metolius River is shown to have extremely small fluctuations in discharge from year to year, ascribed to derivation of a great portion of its flow from ground-water runoff; and its response to fluctuations in annual precipitation lags behind that of the John Day River by about 5 years. Specific techniques and measures for improving seasonal water-supply forecasts are suggested.

1953a. The nationwide water situation, in Subsurface facilities of water management and patterns of supply-Type area studies: U. S. Cong., House Comm. Interior and Insular Affairs, Phys. and Econ. Found. Nat. Res., v. 4, chap. 1, p. 1-20, 14 figs.

This report ventures a broad look at the water situation in the United States, points out the scope of facts both at hand and needed, and suggests some aspects of what the future may bring as to water use. Graphs show the use of water in the United States in 1950, use of water as well as withdrawals and potential supplies in each major drainage basin, and yearly and long-term "swings" in precipitation. Another figure shows the complex pattern of circulation in the hydrologic cycle. The author concludes that a balanced water-information program includes study of precipitation and its variations, evapotranspiration, runoff, ground-water reservoirs and their use, and water quality.

1953b. (and Garrett, A. A., and others). Native and contaminated ground waters in the Long Beach-Santa Ana area, California: U. S. Geol. Survey Water-Supply Paper 1136, 320 p., 19 pls., 29 figs., 33 tables.

In the Long Beach-Santa Ana area, virtually all water wells yielded water of excellent quality until the late twenties. At that time, however, certain wells near the coast began to yield salty water, and subsequently a number of wells and well fields were abandoned. Salty waters are native at certain localities in the area, but in three fairly extensive areas the water that originally was of good quality has depreciated progressively for the last 20 years. The report describes the character and extent of the several types of native ground water; delineates the depreciation and contamination that have occurred; and, so far as possible, explains the depreciation, which is due in part to ocean-water encroachment and in part to percolation of oil-field and industrial wastes. Basic information used in the study included about 5,600 comprehensive chemical analyses and 9,000 incomplete analyses, by many agencies. Companion reports describe the geology (Water-Supply Paper 1109) and ground-water hydrology (Poland 46) of the area.

Poindexter, O. F. See McGuinness, C. L., 49.

Poland, Joseph F. See also Davis, G. H., 54; McGuinness, C. L., 54; Troxell, H. C., 51.

1946. (and others). Hydrology of the Long. Beach-Santa Ana area, California with special reference to the watertightness of the Newport- 
Inglewood structural zone: U. S. Geol. Survey dupl. rept., 198 p., 17 pls., 1 fig.

The Long Beach-Santa Ana area is on the coastal plain in Los Angeles and Orange Counties. Heavy withdrawals have lowered water levels below sea level and induced salt-water encroachment. Possibilities for local control of encroachment are outlined but maintenance of an adequate fresh-water head by decrease in draft, artificial recharge, or both, is the most feasible. The effectiveness of the Newport-Inglewood structural zone to restrain ocean-water encroachment is appraised by means of hydrologic, geologic, and geochemical evidence.

Data for the 580-sq-mi area include 2 water-level maps, water-level profiles, and selected hydrographs.

1947. Summary statement of ground-water conditions and saline contamination along the coast of Orange County, California: Orange County Water District dupl. rept., 20 p., 11 pls.

Summarizes a number of published reports and gives conclusions pertinent to the water problems of Orange County.

1948. (and Garrett, A. A., and Sinnott, Allen). Geology, hydrology, and chemical character of the ground waters in the Torrance-Santa Monica area, Los Angeles County, California: U. S. Geol. Survey dupl. rept., 472 p., 24 pls., 27 figs.; in preparation as Water-Supply Paper 1254.

Geologic features control ground-water occurrence and movement in the west basin, in southwestern Los Angeles County. Study of the extent and sources of saline contamination shows that the principal source is the ocean. Basinwide raising of water levels above sea level, if attainable, would restrain ocean-water encroachment but would greatly reduce fresh-water replenishment. Three possibilities for local control of encroachment are suggested, but only maintenance of fresh-water head above sea level along the saline front by artificial recharge is considered economically feasible.

Data for the 180 -sq-mi area include 3 water-level maps, water-level profiles, 7 geologic cross sections, geochemical maps and graphs, and a geologic map (scale 1:48,000). Estimates are made of pumpage and recharge.

1949. Major ground-water basins of the State: Rept. of the Interim Factfinding Comm. on Water Pollution, Assembly of the State of California 1949 Reg. Sess., p. 128-133.

Gives generalized descriptions of ground-water occurrence in four major ground-water basins: south coastal basin, Ventura County basins, San Diego County basins, and Colorado Desert. Shows how geologic conditions of occurrence are critical in problems of recharge and contamination.

1950. Ground water in California: Min. Eng., v. 187, no. 2, p. 279-284, 2 figs.

Pumpage of ground water in 1948 from the alluvial valleys of California was about 10 million acre-ft per yr. The heavy pumping has created problems of overdraft, and salt-water encroachment from both the ocean and interior saline waters. Steps are being taken to protect and increase the available supply but much more study is needed, especially in the problem of how to utilize ground-water basins effectively for cyclic storage.

1951. (and Davis, G. H., Olmsted, F. H., and Kunkel, Fred). Groundwater storage capacity of the Sacramento Valley, California, in Water 
Resources of California: Calif. Water Res. Board Bull. 1, appendix D, p. 616-632.

The estimated ground-water storage capacity of the Sacramento Valley between 20 and $200 \mathrm{ft}$ below the land surface is about $28,200,000$ acre-ft. About half of this is in the deposits 20 to $100 \mathrm{ft}$ below the surface.

1953. Ground water in California: Spreckels Sugar Beet Bull., v. 17, no. 5 , p. 34-35, 40 .

A generalized discussion of ground-water pumping in California and the problems created by intensive ground-water development. A condensation of a previous paper (Poland 50 ).

Poole, Joe L. See Robinson, T. W., 51.

Porter, Livingston, Jr. See LaRocque, G. A., Jr., 50.

Powell, William J.

1952. Ground water in the vicinity of Trinidad, Colorado: Colo. Water

Conserv. Board, Ground-Water Ser., Circ. 3, 30 p., 2 pls., 3 figs.

As much as $13 \mathrm{ft}$ of saturated alluvium was found by test drilling in the Purgatoire Valley. As much as $150 \mathrm{gpm}$ can be obtained from a well in these deposits; larger quantities can be obtained from batteries of wells or from infiltration galleries.

Data include 29 well records, 42 test-hole logs, and 12 chemical analyses.

Prée, H. L., Jr. See also Cushman, R. V., $53 \mathrm{~b}$; Halberg, H. N., 50.

1952. (and Walker, W. H.). Memorandum on the geology and groundwater resources of the Calvert City-Gilbertsville area, Marshall County, Kentucky: Ky. Agr. and Indus. Devel. Board dupl. rept., 13 p., 2 figs.

The chief aquifers are the St. Louis limestone, sand of the Ripley formation, and alluvial sand and gravel of the Tennessee Valley.

Data for the 12-sq-mi area include 100 well records, 5 well logs, and 6 chemical analyses.

1953. (and Walker, W. H.). Public and industrial water supplies of the Jackson Purchase region, Kentucky: U. S. Geol. Survey Circ. 287, 56 p., 2 pls., 2 figs.

Both the ground- and surface-water supplies are described. Maps and tables show the location of and sources used by the 32 water-supply systems studied, the pumpage, and the chemical quality of the water. Wells 100 to 500 feet deep in the region yield as much as $1,400 \mathrm{gpm}$. The Mississippi, Ohio, and Tennessee Rivers and Kentucky Lake offer an almost unlimited amount of surface water for municipal and industrial use on the western, northern, and eastern boundaries of the region.

Prescott, Glenn C., Jr.

1951. Geology and ground-water resources of Lane County, Kansas: Kans. Geol. Survey Bull. 93, 126 p., 8 pls., 10 figs.

The chief aquifer is the Ogallala formation. A few wells draw water from the Niobrara formation, and deep wells in the Dakota sandstone yield water where shallow supplies cannot be obtained.

Basic data for the 720-sq-mi county include 303 well records, 33 test-hole $\operatorname{logs}, 8$ well $\operatorname{logs}$, a measured geologic section, a fossil list, and 31 chemical analyses. Results are given for aquifer tests of the Ogallala formation. 
Illustrations include 3 geologic cross sections and maps showing water levels, depth to water, saturated thickness of aquifer, and areal geology (scale about $1: 125,000)$.

1952. Geology and ground-water resources of Cheyenne County, Kansas:

Kans. Geol. Survey Bull. 100, 106 p., 8 pls., 10 figs.

Wells in the alluvium of the South Fork of the Republican River have small yields because of the thinness of the aquifer. Yields of upland wells tapping the Ogallala formation are larger, but depths to water are much greater.

Data for the 1,027-sq-mi county include 362 well records, 44 test-hole logs, 2 well $\operatorname{logs}$, 1 measured geologic section, and 20 chemical analyses. Illustrations include 6 geologic cross sections and maps showing water levels, depth to water, saturated thickness, top of the Pierre shale, and areal geology (scale about 1:125,000).

1953. Geology and ground-water resources of Sherman County, Kansas: Kans. Geol. Survey Bull. 105, 130 p., 11 pls., 12 figs.

The chief aquifer, the Ogallala formation, locally yields large quantities of water, particularly in the Beaver Creek valley. The pumpage of $350 \mathrm{mgy}$ in the county is well below the potential yield.

Data for the 1,055-sq-mi county include 326 well records, 31 test-hole logs, 10 well $\log s, 1$ measured section, 24 chemical analyses, and 3 aquifer tests of the Ogallala formation. Maps show water levels, saturated thickness, preTertiary surface, and areal geology (scale about 1:125,000).

1954. (and Branch, J. R., and Wilson, W. W.). Geology and Groundwater resources of Wichita and Greeley Counties, Kansas: Kans. Geol. Survey Bull. 108, 134 p., 7 pls., 13 figs.

The Ogallala formation is chief aquifer. Alluvial deposits and joints in the Niobrara formation yield small supplies locally. The Dakota formation yields salty water.

Data for the 1,507-sq-mi area include 417 well records, 52 test-hole logs, 5 well logs, periodic water-level measurements, 4 aquifer tests of the Ogallala formation, and 30 chemical analyses. Illustrations include 5 geologic cross sections and maps showing water levels, depth to water, bedrock surface, and areal geology (scale about 1:130,000).

1955. Geology and ground-water resources of Graham County, Kansas: Kans. Geol. Survey Bull. 110, 98 p., 10 pls., 7 figs.

Chief aquifer is the Ogallala formation. Other aquifers include terrace deposits in stream valleys, the Crete and Niobrara formations, and the upper part of the Carlile shale. The Dakota formation contains much water but of questionable quality. The most promising areas for ground-water development are in the northwestern part of the county from the Ogallala formation and in places along the South Fork of the Solomon River from terrace deposits.

Data for the 891-sq-mi county include 344 well and spring records, 31 test-hole logs, and 21 chemical analyses. Illustrations include geologic cross sections and show water levels and areal geology (scale about 1:100,000).

Prior, C. $\mathbf{H}$.

1953. (and Schneider, Robert, and Durum, W. H.). Water resources of the Minneapolis-St. Paul area, Minnesota: U. S. Geol. Survey Circ. 274, 49 p., 4 pls., 23 figs. 
Average ground-water use in the area is about $90 \mathrm{mgd}$. Minneapolis and St. Paul together use about $85 \mathrm{mgd}$ from surface sources for public supply. Additional water supplies can be developed from wells and streams. The water-bearing properties of each important aquifer are described and changes in ground-water levels are discussed. The report contains a map showing the distribution of the alluvium and glacial deposits. The water levels and structure of the Jordan sandstone are shown on contour maps. A geologic cross section of the area is given. Information on the temperature and chemical quality of water from the wells is given, including typical analyses of water from several geologic formations. Areas flooded in 1952 are shown on a map. Public water-supply systems are described and the quality of water served is given. Laws affecting the use of water in the area are described briefly and the water-resources potential of the area is evaluated.

Rainwater, Frank H. See Brown, D. W., 55; Fishel, V. C., 53; Sniegocki, R. T., 55.

Randall, Lois E.

1952. Open-file reports of the Water Resources Division, in Reports and maps of the Geological Survey released only in the open files, 1949-50:

U. S. Geol. Survey Circ. 149, 18 p.

Lists open-file reports that contain information on ground water and related geology and hydrology in the United States and Alaska, and that are not scheduled for publication.

1953. Open-file reports of the Water Resources Division, in Reports and maps of the Geological Survey released only in the open files, 1951:

U. S. Geol. Survey Circ. 227, 16 p.

Lists reports that contain information on ground water and related geology and hydrology in the United States, Alaska, Virgin Islands, Puerto Rico, and Chile.

1954a. Open-file reports of the Water Resources Division, in Reports and maps of the Geological Survey released only in the open files, 1952: U. S. Geol. Survey Circ. 263, 14 p.

Lists reports that contain information on ground water and related geology and hydrology in the United States, the Virgin Islands, the Trust Territory of the Pacific, and Japan.

1954b. Open-file reports of the Water Resources Division, in Reports and maps of the Geological Survey released only in the open files, 1953: U. S. Geol. Survey Circ. 337, 20 p.

Lists reports that contain information on ground water and related geology and hydrology in the United States, India, Virgin Islands, Cuba, and Saudi Arabia.

1955. Open-file reports of the Water Resources Division, in Reports and maps of the Geological Survey released only in the open files, 1954:

U. S. Geol. Survey Circ. 364, 25 p.

Lists reports that contain information on ground water and related geology and hydrology in the United States.

Rapp, John R. See also Babcock, H. M., 52b.

1953a. Reconnaissance of the geology and ground-water resources of the La Prele area, Converse County, Wyoming, with a section on chemical 
quality of the ground water by W. H. Durum: U. S. Geol. Survey Circ. 243, 33p., 1 pl., 9 figs.

The White River formation and slope wash and alluvium supply most of the water used in the area, but the Cloverly formation and a sandstone member of the Benton shale contain water under considerable pressure. Recharge from irrigation has caused a water-level rise and waterlogging of low areas. Additional irrigation would increase the waterlogged area. Water from bedrock is generally unsatisfactory for irrigation because of a high percentage of sodium. Also, the fluoride content in some samples from bedrock was greater than is desirable for drinking-water supplies.

Data for the 180 -sq-mi area include 62 well records, 4 well logs, 17 chemical analyses, and a geologic map (scale about 1:50,000).

1953b. (and Babcock, H. M.). Reconnaissance of the geology and groundwater resources of the Glendo-Wendover area, Platte County, Wyoming, with a section on chemical quality of the water by W. H. Durum:

U. S. Geol. Survey Circ. 163, 34 p., 1 pl., 13 figs.

The chief aquifers are the so-called converse sand of the Hartville formation, the Cloverly and Brule formations, the Arikaree sandstone, and alluvium of the principal stream valleys. Yields of $100 \mathrm{gpm}$ or more can be obtained from the so-called Converse sand, and yields of 500 to 1,000 gpm can be developed from alluvium in the valley of the North Platte River and in the lower reaches of the valleys of Cottonwood, Bear, and Horseshoe Creeks. The ground water generally is moderately mineralized, and water from the so-called Converse sand and the alluvium are rated excellent to good for irrigation use.

Data for the 400 -sq-mi area include 62 well and spring records, 8 well logs, an aquifer test of the sand of the Hartville formation, 19 chemical analyses, and a geologic map (scale about 1:50,000).

1953c. (and Warner, D. A., and Morgan, A. M.). Geology and groundwater resources of the Egbert-Pine Bluffs-Carpenter area, Laramie County, Wyoming: U. S. Geol. Survey Water-Supply Paper 1140, 67 p., 3 pls., 4 figs.

The area is essentially an upland dissected by Lodgepole and Crow Creeks. The Brule formation crops out in the valleys and the Arikaree and Ogallala formations cap the upland area. Terrace deposits and alluvium occur in the valleys. Ground water was used to irrigate 9,800 acres in 1949 . The areas most favorable for additional development are the terrace lands east of Carpenter and the terraces in the Lodgepole Creek valley. The chief aquifers are the Brule formation and Pleistocene gravel. The water is hard but usable for most purposes.

Data for the 380 -sq-mi area include 224 well records, 41 test-hole logs, 7 well logs, discharge data, and specific capacities of wells. Maps show water levels, depth to water, and areal geology (scale 1:96,000).

Rasmussen, William C. See also Groot, J. J., 54; Marine, I. W., 55.

1947a. Geology and ground-water resources of Caldwell County, Texas:

Tex. Board Water Engineers dupl. rept., 59 p., 2 pls.

The chief aquifers are sand beds in the Wilcox group and sand and gravel of Pleistocene and Recent alluvial deposits. Large areas in the northwestern third of the county are underlain by impermeable marl and shale, and water supplies depend on cisterns and stock ponds. Prior to World War II, oil-field 
wastes contaminated the Pleistocene aquifer supplying Lockhart, but by 1946 the salt had mostly been flushed out. The massive Carrizo sand crosses the eastern side of the County, and adundant water supplies may be available from properly constructed wells in this area.

Data for the 544-sq-mi area include 535 well records, 14 well logs, and 34 comprehensive and 238 partial chemical analyses. A geologic cross section and a geologic map (scale about 1:150,000) are included.

1947b. Ground water in the deposits of ancient Lake Dakota, Dickey County, North Dakota: U. S. Geol. Survey N. Dak. Ground-Water Studies 4, 86 p., 5 pls., 10 figs.

Use of shallow ground water in the Oakes plain in North Dakota was about $180 \mathrm{mgy}$ in 1940 and 1941 . In addition, natural discharge was about 525 mgy. Storage in the lake deposits is calculated at 235,000 million gallons. The feasibility of irrigation from high-capacity, relatively shallow wells is considered. As an illustration of irrigation potential, $25 \mathrm{sq} \mathrm{mi}$, about onefourth of the farm area, could be irrigated yearly to a depth of $1 \mathrm{ft}$ for 24 years before the general water level would decline $23 \mathrm{ft}$.

Data for the 130 -sq-mi area include 372 well records, 12 test-hole $\operatorname{logs}, 7$ chemical analyses, determinations of physical properties of sediments, aquifer tests of deposits of glacial Lake Dakota, 5 cross sections, a depth-to-water map, a water-level map, and topographic and geologic maps (scale about $1: 140,000)$.

1952. Yield of ground-water reservoirs calculated by geo-mathematical analogy: Maryland-Delaware Water and Sewage Assoc. 25th Ann. Conf. Proc., p. 42-62, 4 figs.

The requisite and qualifying conditions for estimating ground-water yield as limited by geologic, hydrologic, and mathematical control are described for the " 400 -ft" aquifer at Cambridge, Maryland. The image method and the pumpage increment method are described and used.

1953. (and Haigler, L. B.). Ground-water problems in highway construction and maintenance: Del. Geol. Survey Bull. 1, 24 p., 8 figs.

The occurrence of ground water is discussed in relation to certain problems in highway construction and maintenance: subdrainage of roads, quicksand, arrest of soil creep in road cuts, construction of lower and larger culverts necessitated by the farm-drainage program, prevention of failure of bridge abutments and retaining walls, and the water-cement ratio of subwater-table concrete. The technique of soil stabilization by electroosmosis is reviewed in the hope that it might find application to road work and pile setting.

1955a. Magnitude of the ground waters of Delaware: Maryland-Delaware Water and Sewage Assoc., 28th Ann. Conf. Proc., p. 53-66, 2 figs.

Delaware has abundant ground water in storage, ample annual recharge, and at least nine important aquifers suitable for sustained withdrawal. A geologic cross section shows the relations of the aquifers. Data given for each of the nine major aquifers include estimated average coefficient of storage, available storage reserve, average recharge, rejected recharge, and range in coefficients of transmissibility.

1955b. (and Slaughter, T. H.). The water resources of Somerset, Wicomico, and Worcester Counties; The ground-water resources: Md. Dept. Geology, Mines, and Water Res. Bull. 16, p. 1-469, pls. 1-15, figs. 1-46. 
Ground water occurs in 14 separate sand aquifers, which range in depth from just below the land surface to more than 7,700 ft below. Four of these aquifers are used extensively, to depths as great as $300 \mathrm{ft}$. Eight of them are used to a slight extent in most of the area but to an important extent locally, and wells in them produce from depths as great as 1,706 ft below the land surface. Two of the aquifers, which contain highly mineralized water, lie at depths of several thousand feet and have not been tapped for water in the area. Water for supplemental irrigation or other moderately large-scale uses is available from wells in much of the area.

Three new aquifers are named and defined in the Miocene series: the Nanticoke aquifer in the Calvert formation and the Manokin and Pocomoke aquifers in the unit identified as the Yorktown and Cohansey(?) formations undifferentiated. Also, three new formations are named and described in the Pleistocene series: the Beaverdam sand, the Walston silt, and the Parsonsburg sand.

Peculiar sand-rimmed oval basins pock-mark the Coastal Plain in the three counties and account in part for both the high infiltration rates and the high evapotranspiration losses. They are termed Maryland basins, and are described as similar in some respects to Carolina bays and in others to depressions in New Jersey called Jersey basins.

Data for the land area of $1,200 \mathrm{sq} \mathrm{mi}$ include 1,668 well records, 477 well $\operatorname{logs}, 107$ chemical analyses, and particle-size analyses. A 2-year study of infiltration in the Beaverdam Creek basin near Salisbury is summarized. Data and analyses are given for aquifer tests of Pleistocene and Pliocene(?) formations at Salisbury and Ocean City, of the Pocomoke aquifer at Pocomoke City and Ocean City, and of the Manokin aquifer at Princess Anne, Ocean City, and Snow Hill. Well-construction problems caused by high screen loss are described and illustrated, and well-cleaning methods also are described (p. 170). Some 20 maps show altitude of formational contacts and thickness of geologic units in the area.

Reck, Charles W.

1952. (and Simmons, E. T.). Water resources of the Buffalo-Niagara Falls region: U. S. Geol. Survey Circ. 173, 26 p., 1 pl., 22 figs.

The Buffalo-Niagara Falls region has an abundant supply of water of good chemical quality. The average flow of the Niagara River is $125,000 \mathrm{mgd}$, which is sufficient to supply 70 percent of the estimated daily needs of water in the United States for all purposes except water power. The present use in the region is $1,700 \mathrm{mgd}$, or less than 2 percent of the potential supply. A map shows the chief aquifers and their water-bearing properties. Information on the chemical quality and temperature of ground wates is given. The public water-supply systems in the region are described briefly. The present use of water for public and industrial supplies, water power, and navigation is given. Laws affecting the use or pollution of water in the region are described briefly, and a summary of the potential water resources of the region is given.

Reed, Edwin W. See also Jacobson, C. L., 49; Schoff, S. L., 51c, 51b.

1947. (and Schoff, S. L.). Ground-water storage increases in Tillman County, Oklahoma: Okla. Geol. Survey Hopper, v. 7, no. 8, p. 77-80. Describes observed rises in ground-water levels.

1949. Unusual fluctuations in Rush Springs wells: Okla. Geol. Survey Hopper, v. 9, no. 7, p. 69-70. 
Relatively large and rapid fluctuations in water level were recorded on March 25 and 26, 1949, in a well that taps the Rush Spring sandstone. The fluctuations occurred during a severe thunderstorm which was accompanied by heavy rains, high winds, and tornadoes. Assuming a barometric efficiency of 50 percent for the well, a change in atmospheric pressure of more than 1 inch of mercury would be required to cause the $0.84-\mathrm{ft}$ water-level decline recorded.

1950. Increased use of ground water for irrigation in the Duke area, Oklahoma: Okla. Geol. Survey Hopper, v. 10, no. 9, p. 86-90.

Data on ground-water levels of water and use for irrigation are summarized, and 5 chemical analyses reported.

1952a. (and Mogg, J. L., Barclay, J. E., and Peden, G. H.). Groundwater resources of the terrace deposits along the northeast side of the Cimarron River in Alfalfa, Garfield, Kingfisher, and Major Counties, Oklahoma: Okla. Div. Water Res. Bull. 9, 101 p., 9 pls., 5 figs.

The chief aquifer in the 600 -sq-mi area investigated is a terrace deposit of stream-laid sediments as much as $120 \mathrm{ft}$ thick. Sand and gravel constitute about 42 percent of the saturated sediments. Aquifer tests showed transmissibilities from about 6,200 to $76,000 \mathrm{gpd}$ per $\mathrm{ft}$. The perennial yield of the deposits is estimated as $137 \mathrm{gpm}$ per sq mi. If half the water in storage can be recovered by pumping, withdrawals at the estimated rate of the perennial safe yield could continue through 5 years, even if no recharge occurred.

Data include 1,700 well records, 66 test-hole $\operatorname{logs}$, 116 well logs, 4 measured sections, and 66 chemical analyses. Aquifer tests were made of terrace deposits and Permian rocks. Illustrations include 4 geologic cross sections, a water-level map, a saturated-thickness map, a bedrock-surface map, and an areal geologic map (scale about 1:130,000) which shows also the thickness of the terrace deposits.

1952b. (and Schoff, S. L.). Aquifers in Ottawa County, Oklahoma: Okla. Acad. Sei. Proc., v. 33, p. 194-195.

The chief aquifers are the Arbuckle group of Cambrian and Ordovician age and the Boone limestone of Mississippian age. The rocks of the Arbuckle group function as a huge storage reservoir, but intensive pumping has lowered water levels considerably. On the other hand, the Boone limestone contains muct yater, and water levels in it have not yet declined appreciably.

1955. (and Schoff, S. L., and Branson, C. C.). Ground-water resources of Ottaw. County Oklahoma: Okla. Geol. Survey Bull. 72, 203 p., 1 pl., 14 figs.

The chief aquifers are the Arbuckle group and the Boone formation. Mine drainage and structural control of ground-water occurrence are discussed. Three aquifer tests provide data for predicting drawdowns and locating barriers to ground-water flow.

Data for the 504-sq-mi county include 79 well records, 14 test-hole logs, 30 well $\operatorname{logs}$, 37 chemical analyses, water-level data, and a geological map (scale about 1:140,000).

Reed, Eugene C. See Waite, H. A., 46.

Reis, Donald J. See Mundorff, M. J., 52 
Remson, Irwin. See also Barksdale, H. C., $55 \mathrm{~b}$.

1955a. (and Fox, G. S.). Capillary losses from ground water: Am. Geophys. Union Trans., v. 36, no. 2, p. 304-310, 4 figs.

A method is presented for estimating the discharge by evaporation of ground water rising from the water table by capillarity. The term potential capillary water loss is defined.

1955b. (and Fox, G. S.). The displacement of calibration curves for electrical soil-moisture units: Am. Geophys. Union Trans., v. 36, no. 5, p. 821-826, 1 fig.

Comparison of field and laboratory calibrations of soil-moisture blocks indicate that laboratory calibrations are generally unreliable.

1955c. (and Lang, S. M.). A pumping-test method for the determination of specific yield: Am. Geophys. Union Trans., v. 36, no. 2, p. 321-325, 1 fig.

The specific yield may be determined during the course of an equilibrium aquifer test by comparing the volume of dewatered material in the cone of depression with the total volume of water discharged. An equation is developed to express the volume of dewatered material in terms of test data. A related equation indicates the magnitude of entrance losses in the pumped well.

Repenning, Charles A. See Harshbarger, J. W., 53, 54.

Richardson, Raymond M. See also Warde, J. M., 55.

1950. List of references pertaining to electrical well logging: U. S. Geol. Survey dupl. bibliography, 29 p.

References are listed by author but are not annotated.

Rhodehamel, Edward C. See Stuart, W. T., 54.

Riggs, H. C.

1953. A method of forecasting low flow of streams: Am. Geophys. Union Trans., v. 34, no. 3, p. 427-434, 7 figs.

The discharge of streams during periods of low flow can be forecast by use of the base-flow depletion curve and frequency curves of runoff from concurrent precipitation and snow melt. The method is illustrated by application to two streams in the Columbia River basin.

\section{Rima, Donald R.}

1955. Ground-water resources of the Lansdale area, Pennsylvania: Pa. Geol. Survey, 4th ser., Prog. Rept. 146, 24 p., 7 pls., 4 figs.

Ground water occurs in the Brunswick shale in a water-table aquifer near the surface and in several semiartesian aquifers at depth. Well exploration indicates that ground water is rarely found below a depth of $600 \mathrm{ft}$. The most favorable areas for the development of additional supplies are near streams and remote from heavily pumped wells.

Data for the 25-sq-mi area include 110 well records, 3 chemical analyses, and 12 electric logs of wells. Well exploration included caliper logging, flowmeter tests, and electric logging.

Roberts, Claude M. See also Halberg, H. N., 49.

1947. (and Jaster, M. C.). Record of wells in Queens County, New York, Supp. 1; in addition to those published in U. S. Geol. Survey Prof. 
Paper 44 and New York State Water Power and Control Comm. Bull. GW-6: N. Y. Water Power and Control Comm. Bull. GW-11, 123 p., well map.

Logs are given for 160 wells.

Robinson, Thomas W. See also Eakin, T. E., 49; Gatewood, J. S., 50; Loeltz, O. J., 49; Maxey, G. B., 47.

1946. (and Fredericks, J. C.). Ground water in Lovelock Valley, Nevada:

Nev. State Engineer Water Res. Bull. 2, 25 p., 1 pl., 4 figs.

The most favorable location for developing potable ground-water supplies is in the transition zone of interfingering lake beds and alluvial deposits. Water from the sediments of Lake Lahontan in the lower valley generally is highly mineralized.

Data include 31 well records, 13 well logs, and 13 chemical analyses.

1947. (and others). Water levels and artesian pressure in wells in Las Vegas Valley and in other valleys in Nevada, 1913-1945: Nev. State Engineer Bull. 3, 77 p., 2 figs.

1948. (and Phoenix, D. A.). Ground water in Spanish Spring and Sun Valleys, Washoe County, Nevada: Nev. State Engineer dupl. rept., 26 p., 1 pl.

The area is favorable only for development of wells for stock or domestic supply. The average annual recharge of the valleys is small, ranging from 20 to 40 acre-ft.

Data include 34 well records, 8 well logs, and 7 chemical analyses.

1949a. Ground water in Nevada, in Industrial Minerals: Colo. School Mines Quart., v. 45, no. 4B, p. 33-38.

Exhaustion of ground water in Nevada due to overpumping is a problem only in the Las Vegas Valley. Paper reviews briefly a number of groundwater problems in Nevada.

1949b. Areas and use of water by phreatophytes in the Western United States: U. S. Geol. Survey dupl. rept., $11 \mathrm{p}$.

Estimates of the area covered by phreatophytes and their annual use of water are given for 13 of the Western States. Partial data given show an area of 10,852,000 acres of phreatophytes and an annual use of 15,267,800 acre-ft of water. Extrapolation of the data suggests a total of 15,000,000 acres of phreatophytes and a total water use of $20,000,000$ to $25,000,000$ acre-ft per year in the 17 Western States.

1951. (and Loeltz, O. J., and Poole, J. L.). Ground water in the vicinity of Verdi, Washoe County, Nevada: Nev. State Engineer dupl. rept., 28 p., 2 pls.

The chief aquifer is coarse river gravel underlying a terrace of the Truckee River on which Verdi is built. This gravel is recharged chiefly from Steamboat ditch and the Sierra Pacific canal, both of which divert water from the Truckee River.

Data include 44 well records and 28 well logs. Maps show water levels and generalized geology (scale about 1:16,000).

1952a. Phreatophytes and their relation to water in western United States: Am. Geophys. Union Trans., v. 33, no. 1, p. 57-61, 1 fig.

Phreatophytes are estimated to cover about 15 million acres in the 17 Western States, and may waste as much as 20 to 25 million acre-ft per yr 
of water into the atmosphere. The water used by these plants probably represents the largest remaining source of reclaimable water in the arid western United States. Salvage of perhaps 25 percent of this water may be feasible but methods for doing so have not passed the experimental stage.

1952b. Water thieves: Chemurgic Digest, v. 11, no. 10, p. 12-15.

Reviews the phreatophyte problem in the West and gives data on area and use of water by phreatophytes in 14 of the 17 Western States.

1952c (1955). Phreatophytes versus ground water in western United

States: Nev. State Engineer 7th Water Conf. Proc., p. 68-76.

Methods of salvaging water that would otherwise be wasted by phreatophytes are reviewed.

1953a. Big Smoky Valley, Nevada, in Subsurface facilities of water management and patterns of supply-Type area studies: U. S. Cong., House Comm. Interior and Insular Affairs, Phys. and Econ. Found. Nat. Res., v. 4, chap. 8, p. 132-146, 13 figs.

To win greater returns from the water supply the following could be done: 1) remove phreatophytes, 2) substitute forage grasses for native vegetation, 3) use runoff from mountains to recharge valley fill, and 4) salvage natural consumptive wastes by lowering the water table. Present knowledge is inadequate; data needed include: 1) adequate topographic maps; 2) data from a network of climatologic stations maintained for a term of years; 3 ) data from gaging stations located on bedrock and low in the mountains but above the alluvial fans; these should be maintained for a term of years on about 15 of the 40 -odd streams; 4) data on areal extent, thickness, and hydraulics of the valley fill; and 5) chemical-quality data for all the natural waters.

1953b. Phreatophytes-Appropriators of ground water: Assoc. Western State Engineers 26th Ann. Convention Proc., p. 106-114.

Similar to Robinson 52a and 52b.

1954 (1955). Some developments and problems in the study of phreatophytes: Nev. State Engineer 8th Water Conf. Proc., p. 98-105.

Reviews attempts at control of phreatophytes. Waste of water by phreatophytes is not confined to arid regions but occurs in humid regions as well.

Robinson, W. H.

1953. (and Ivey, J. B., and Billingsley, G. A.). Water supply of the Birmingham area, Alabama: U. S. Geol. Survey Circ. 254, 53 p., 2 pls., 31 figs.

Impounding reservoirs and rather long pipelines will be required to provide large additional quantities of water in the area; however, moderate supplies may be obtained from wells, springs, and mines. The public watersupply systems are described and the source and quality of the water served is given. The water-bearing properties of the important geologic formations are given. Tables and graphs show the chemical quality and temperature of water from ground and surface sources and from public supplies. Laws affecting the use of water in the area are described briefly and the water-resources potential of the area is summarized.

Romberg, F. E. See George, W. O., 51 b. 


\section{Rorabaugh, M. I.}

1946a. Ground-water resources of the southwestern part of the Louisville area, Kentucky: U. S. Geol. Survey dupl. rept., 39 p., 15 figs.

On the basis of 1945 data, estimates of ground-water supplies for the area are as follows: storage, $\mathbf{1 . 5}$ billion gallons per foot below the water table; underflow into the glacial-outwash material from the bedrock to the east, $1 \mathrm{mgd}$; infiltration from rainfall on the area, $11 \mathrm{mgd}$. Loss to the river in the undeveloped area is estimated as $0.8 \mathrm{mgd}$ per linear mile along the river. Additional supplies can be developed by induced infiltration from the Ohio River. Bedrock cannot be considered a potential source of large supplies. The quality and temperature of the ground water are suitable for domestic or industrial uses.

Maps show physiographic units, bedrock surface, water levels, and thickness of aquifer. Other data for the 50-sq-mi area include 46 test-hole records, particle-size analyses, 6 comprehensive and 66 partial chemical analyses, and results of an electrical-resistivity survey.

1946b. Inventory of water wells, Louisville area: City of Louisville and Jefferson County, Ky., dupl. rept., 35 p., 1 map.

Data include records of more than 700 wells.

1948. Ground-water resources of the northeastern part of the Louisville area, Kentucky: City of Louisville dupl. rept., 77 p., 42 figs.; U. S. Geol. Survey Water-Supply Paper 1360-B.

Ground-water storage is 7 billion gallons. Ground-water levels are affected by changes in river stage, rainfall, and pumping in downtown Louisville, 3 miles to the southwest. Analysis of an aquifer test of alluvium of the Ohio Valley proves that infiltration can be induced from the river. Studies to determine the degree of connection between the river and aquifer were made on the basis of chemical analyses, sections showing temperature distribution in the aquifer during the test, shapes of water-level profile, and shapes of time-drawdown curves for several observation wells. Potential supply based on induced infiltration is estimated as $280 \mathrm{mgd}$.

Data for the 3-sq-mi area include 56 well records, 30 test-hole logs, and comprehensive and partial chemical analyses. The term river factor is proposed and defined (p. 43). The theory of induced infiltration is discussed and an equation is developed for determining the effective distance to a line source of ground-water recharge in a stream.

1949a. Investigation discloses large ground-water supply: Louisville Engineer and Scientist, v. 5, no. 4, p. 1, 9-10.

The aquifer of sand and gravel contains, in a 3-sq-mi area in the northeastern part of the Louisville area, 7 billion gallons of ground water or about 100 million gallons per vertical foot of aquifer. About $280 \mathrm{mgd}$ of goodquality water can be developed by induced infiltration of Ohio River water.

1949b. Progress report on the ground-water resources of the Louisville area, Kentucky, 1945-49: City of Louisville and Jefferson County, Ky., dupl. rept., 64 p., 17 figs.

Ground-water conditions improved in the area during the 5-year period, February 1944 to December 1948. The average pumpage of $32.5 \mathrm{mgd}$ in 1948 was only about half the wartime peak of $61.7 \mathrm{mgd}$ in 1943 . During 1948, artificial recharge by industries was at an average rate of $1.3 \mathrm{mgd}$.

Illustrations for the 60-sq-mi area include 7 water-level maps and 2 maps 
showing water-level change. Partial chemical analyses, made annually for selected wells, are tabulated. Temperatures of ground water have been investigated more intensively than in the usual areal investigation.

1949c. Memorandum on multiple-step drawdown tests, southwest well field, Houston, Texas, February 1949: U. S. Geol. Survey dupl. rept., 8 p., 4 figs.

The memorandum describes tests made on wells for the purpose of field checking theory on head losses in wells. The results were less reliable than could be desired because field conditions were not ideal. One of the figures shows variation of specific capacity with discharge and with time.

1951. Stream-bed percolation in development of water supplies: Internat. Union Geodesy and Geophysics, Internat. Assoc. Sci. Hydrology, Brussels, 1951, v. 2, p. 165-174, 1 fig.

Factors to be considered in the installation and use of wells designed to induce recharge from streamflow are low flow of the stream; permeability, thickness, storage capacity, and storage coefficient of the aquifer; unwatering of the aquifer; available head; head loss associated with the installation; interference from other installations; and viscosity changes due to temperature changes of the water in the stream.

Graphs for a 5-year period show performance data of a collector-type well at Louisville, Kentucky.

1953a. Graphical and theoretical analysis of step-drawdown test of artesian well: Am. Soc. Civil Engineers Proc., v. 79, Separate 362, 23 p., 9 figs.

A graphical method for determining empirically the laminar and turbulent head losses in and near wells is given. The method is compared and related to theoretical equations. A procedure is given for computing the head-loss distribution outside the pumped well for various pumping rates. Analysis is made of the variation of specific capacity with discharge, and of the importance of well radius in well design.

1953b. (and Schrader, F. F., and Laird, L. B.). Water resources of the Louisville area, Kentucky and Indiana: U. S. Geol. Survey Circ. 276, 49 p., 2 pls., 41 figs.

Total water use in 1952 was $765 \mathrm{mgd}$, including $660 \mathrm{mgd}$ of untreated Ohio River water used for industrial cooling and returned to the river. Additional water supplies can be developed from wells and streams. The principles of induced infiltration of river water and its effects on the temperature and chemical quality of the water are described. Public watersupply systems are described briefly and the water-resources potential of the area is evaluated.

Illustrations include cross sections of the Ohio Valley and maps showing availability of ground water, water levels in alluvium, and maximum and minimum temperatures of ground water.

Rose, Nicholas Anthony. See George, W. O., 42.

Rosier, A. J.

1953. Ground-water resources of the Rapid Valley unit, Cheyenne Division, South Dakota, with a section on surface waters of Rapid Valley by L. J. Snell: U. S. Geol. Survey Circ. 201, 32 p., 2 pls., 12 figs. The flood-plain and terrace deposits of the Rapid Valley unit contain 
abundant supplies of ground water where recharge is effected by seepage from irrigation. In August 1949, ground water was less than $5 \mathrm{ft}$ below the land surface in more than one-third of the irrigated area; this is reported by land owners to have been the condition since soon after irrigation was begun in the area. In the parts of the area not now affected by irrigation, the water table is $6 \mathrm{ft}$ to $42 \mathrm{ft}$ below land surface.

Lining of the irrigation canals would reduce seepage from the canals and would effect a lowering of ground-water levels. If irrigation is extended to other parts of the area, drainage facilities will be necessary if existing conditions of waterlogging are not to be aggravated and if the waterlogging of other low-lying areas is to be prevented. If about 10,000 acre-ft per yr of ground water were withdrawn from shallow sources, the water-table would be lowered in areas now waterlogged, and this would aid in the restoration of these areas to cultivation.

Data for the 71-sq-mi area include 173 well records, 21 test-hole logs, and water-level measurements.

Rothrock, E. P.

1947. (and Otton, E. G.). Ground-water resources of the Sioux Falls area, South Dakota: S. Dak. Geol. Survey Rept. Inv. 56, 2 pts., 108 p., 15 figs.

Big Sioux Valley is underlain by permeable materials in which the ground-water underflow is $1.8 \mathrm{mgd}$. Skunk Creek valley is a potential source of 3 to $5 \mathrm{mgd}$, but the water may be more highly mineralized than the present municipal supply.

Data include 189 well records, 51 well $\operatorname{logs}, 21$ chemical analyses, and particle-size analyses. Results are given for aquifer tests of sand and gravel in the Big Sioux Valley at Sioux Falls. A map (scale about 1:150,000) shows the areal geology of Minnehaha County.

Rowley, J. H. See Broadhurst, W. L., 50b.

Sandberg, C. H. See White, D. E., 53.

Sanderson, E. E. See Cummins, J. W., 47 ; Norris, S. E., $52 \mathrm{~b}$.

Sanford, Thomas H., Jr.

1955. Progress report on ground-water studies in the Huntsville area, Alabama: Ala. Geol. Survey Inf. Ser. 1, 4 p., 7 figs.

A map shows water levels in Huntsville area.

Sayre, A. Nelson. See also Ferris, J. G., 55.

1947-57. (and others). Water levels and artesian pressures in observation wells in the United States 1944-55: U. S. Geol. Survey WaterSupply Papers. For year of record and serial number of water-supply paper, see table 1 and figure 1 .

1948a. Oscar Edward Meinzer: Am. Geophys. Union Trans., v. 29, no. 4, p. 455-456, 1 fig.

A brief biography.

1948b. Ground-water investigations in the United States: Econ. Geology, v. 43, no. 7, p. 547-552; reprinted in Smithsonian Inst. Board Regents Ann. Rept., 1949, p. 219-225.

Outlines briefly the broad problems of water supply, water control, and 
conservation. Reviews the Federal and the Federal State cooperative investigations of ground water in the United States.

1948c. (and Stringfield, V. T.). Artificial recharge of ground-water reservoirs: Am. Water Works Assoc. Jour., v. 40, no. 11, p. 1152-1158.

As the use of water approaches the limits of the available supply, artificial recharge will become increasingly important in the national economy.

1949. Memorial to Oscar Edward Meinzer: Geol. Soc. America Proc. 1948, p. 197-206, pl. 13.

A brief biography, with a bibliography of Meinzer's published works.

1950a. Application of geology to the investigation of our water resources in Applied geology, a symposium: Colo. School Mines Quart., v. 45, no. 1B, p. 75-105, 3 figs.

Geologic techniques used in ground-water investigation, though similar to those used in other mineral investigations, must allow for the fact that ground water is replenishable. Studies may involve geologic mapping in conjunction with stratigraphy, structure, paleontology, sedimentation, and geomorphology; electrical and gamma-ray logging in wells to locate formation contacts and zones of permeable and impermeable rocks, and of fresh and salt water; electrical-resistivity surveys to outline buried valleys and to determine the location of permeable rocks and of fresh-water-salt-water contacts; and seismic surveys to locate buried valleys and the water table. Four types of ground-water problems, which have caused the decline and fall of several ancient civilizations, are related to geologic processes and also to each other: (1) gradual accumulation of salt in the soil and in the ground water; (2) gradual rise of the water table; (3) erosion and siltation; and (4) maintenance of adequate water supplies of good quality.

1950b. Ground water: Sci. Am., v. 183, no. 5, p. 14-19, 5 figs.

The geographical distribution of ground water is far from uniform, and this, rather than an overall shortage of water, is responsible for most groundwater problems in the United States.

1950c. Ground-water conditions and problems in the Colorado River drainage basin, with a discussion by A. M. Piper: Colo. River Water Users Assoc. 6th Ann. Conf. Proc., p. 21-41.

Reviews some of the highlights in the use of water in the West, discusses the hydrologic cycle and its significance, gives suggestions for increasing the overall water supply, and outlines miscellaneous problems arising from water development.

1951. (and Taylor, G. C., Jr.). Ground-water resources of the Republic of El Salvador, Central America: U. S. Geol. Survey Water-Supply Paper 1079-D, p. 155-225, pl. 3, fig. 7.

Describes the ground-water resources of El Salvador, particularly with reference to development of ground water for public water supplies and domestic use. Physiographic and geologic features as they relate to groundwater occurrence also are considered.

Includes map (scale 1:800,000) showing physiographic districts, principal volcanoes, and towns and cities studied in municipal water-supply survey.

1953a. Ground-water problems of the West: Assoc. Western State Engineers 26th Ann. Convention Proc., p. 84-90. 
Reviews development of water use in the West and gives suggestions for conserving water resources.

1953b. Review of "Water-A study of its properties, its constitution, its circulation on the earth, and its utilization by man," by Cyril S. Fox: Am. Jour. Sci., v. 251, no. 7, p. 549-550.

1953c. Need of comprehensive basic-data program for water resources: Colorado River Water Users Assoc., 10th Ann. Conf. Proc., p. 34-36. Ground-water use in the United States increased from $10,000 \mathrm{mgd}$ in 1935 to $20,000 \mathrm{mgd}$ in 1945 and $30,000 \mathrm{mgd}$ in 1950 . To enable even greater use in the future, water resources must be used more wisely and efficiently.

1954. (and McGuinness, C. L.). Our water resources: Natl. Wildlife Federation Proc. 18th Ann. Convention, p. 96-100.

Reviews the squeeze between a fixed supply and an increasing demand for water in the United States.

Scalapino, Ralph A. See also Barnes, J. R., 49; Hood, J. W., 51.

1949. Ground-water resources of the El Paso area, Texas, with a section on quality of water by Burdge Irelan; Prog. Rept. 6: Tex. Board Water Engineers dupl. rept., 22 p.

Discusses pumpage, water-level fluctuations, and reduction of groundwater storage in the period 1936-48. Salt-water encroachment and artificial recharge of the artesian reservoir also are discussed.

Data include pumpage for years 1936-48, periodic water-level measurements, results of aquifer tests on bolson deposits, and periodic chemical analyses for 24 wells.

1950. Development of ground water for irrigation in the Dell City area, Hudspeth County, Texas: Tex. Board Water Engineers Bull. 5004, 38 p., 1 pl., 1 fig.

Data include 112 well records, 29 well $\operatorname{logs}, 27$ chemical analyses, and a geologic map (scale about 1:120,000) revised from a map by P. B. King.

Scarcia, Glenn. See Turcan, A. N., Jr.

Sceva, Jack E.

1950. Preliminary report on the ground-water resources of southwestern Skagit County, Washington: U. S. Geol. Survey Wash. State GroundWater Rept. 1, 40 p., 3 pls., 3 figs.

The chief aquifers are at depths of less than $100 \mathrm{ft}$ in the alluvium of the Skagit River delta. The possibilities and limitations of inducing infiltration from the Skagit River by pumping heavily from wells are described.

Data for the 160-sq-mi area include 63 well records, 26 well logs, 7 chemical analyses, and an areal geologic map (scale about 1:100,000).

1955. (and Wegner, D. E.). Records of wells and springs, water levels, and quality of ground water in central Pierce County, Washington:

U. S. Geol. Survey dupl. rept., 261 p., 8 pls., 7 figs.

Sand and gravel deposited chiefly as glacial outwash are the important aquifers. The wells range in depth from less than 100 to several hundred ft. Many wells yield more than $500 \mathrm{gpm}$ and one well yields more than $9,000 \mathrm{gpm}$.

Data include more than 950 well records and 63 spring records, 298 well logs, and 40 chemical analyses. A map shows water levels in the Tacoma area. 
Schaefer, Edward J. See also Bernhagen, R. J., 47.

1946a. Records of ground-water levels in Ohio and their significance;

Ohio State Univ. Eng. Expt. Sta. News, v. 18, no. 2, p. 26-30, 1 fig.

Serious ground-water depletion has occurred locally as a result of overpumping. In most areas, however, ground-water supplies have been obtained without continued lowering of water levels. Recharge generally occurs in winter and spring and depletion occurs in summer and fall.

1946b. (and White, G. W., and Van Tuyl, D. W.). The ground-water resources of the glacial deposits in the vicinity of Canton, Ohio: Ohio Water Res. Bull. 3, 60 p., 6 pls., 7 figs.

Glacial materials range from relatively impermeable till in areas of ground moraine to permeable gravels in the outwash plains and valley trains. These materials range in thickness from $50 \mathrm{ft}$ in the uplands to more than $200 \mathrm{ft}$ in buried valleys. The buried valleys offer the best sites for obtaining large ground-water supplies.

Data include 6 well logs, 4 chemical analyses, and a geologic cross section. Maps show thickness of glacial drift, bedrock surface (scale about 1:90,000), and surficial geology (scale about 1:75,000).

1950. Evaluating the hydraulic properties of water-bearing formations: Ohio State Univ. Eng. Expt. Sta. News, v. 22, no. 2, p. 17-19, 39-41, 3 figs.

A general review of aquifer-test methods.

Schlanger, S. $\mathbf{O}$.

1955. (and Brookhart, J. W.). Geology and water resources of Falalop Island, Ulithi Atoll, Western Caroline Islands: Am. Jour. Sci., v. 253, no. 10 , p. 553-573, 4 pls., 6 figs.

A small supply of potable water can be obtained from wells on Falalop. Pumping rates should be kept low so as not to induce salt-water encroachment.

Schneider, Robert. See also Prior, C. H., 53.

1947. Ground-water conditions and problems in the upper Mississippi

River Embayment: Econ. Geology, v. 42, no. 7, p. 626-633, 2 figs.

The upper portion of the embayment covers 45,000 sq $\mathrm{mi}$ in the Mississippi Valley from near the 34th parallel northward to the mouth of the Ohio River. It includes parts of Arkansas, Mississippi, Tennessee, Kentucky, and Missouri. Of the water used in the area, 95 percent is ground water. Productive aquifers extend throughout most of the region, but the total quantity of water perennially available is unknown.

1948. (and Cushing, E. M.). Geology and water-bearing properties of the "1,400-foot" sand in the Memphis area (Tennessee)-A progress report: U. S. Geol. Survey Circ. 33, 13 p., 2 pls., 3 figs.

The "1,400-foot" sand forms an increasingly important aquifer in the Memphis area. It is a part of the Wilcox group of Eocene age, averages about $210 \mathrm{ft}$ in thickness in the Memphis area, and generally occurs about 1,200 to $1,400 \mathrm{ft}$ below the land surface. It dips to the west at about $30 \mathrm{ft}$ per mile toward the axis of the upper Mississippi Embayment. With the "500-foot" sand in the overlying Claiborne group, also of Eocene age, it furnishes the bulk of the water used in the Memphis area. So far the "500-foot" sand has yielded the largest part of the approximately $100 \mathrm{mgd}$ 
pumped from wells in the area; the "1,400-foot" sand yielded only about $9 \mathrm{mgd}$ in 1946.

Data include a geologic cross section, a map of the top of the " 1,400 -foot" sand, 22 particle-size analyses, 3 chemical analyses, and results for aquifer tests of the "1,400-foot" sand.

1949. A hypothesis on the origin of a limonitic layer in beds of Eocene age in Fayette County, Tennessee: Econ. Geology, v. 44, no. 7, p. 621-623.

Suggests that solid ferrous carbonate was precipitated from artesian water moving upward through a thin, leaky clay bed. Loss in head caused release of carbon dioxide and provided a suitable environment for precipitation.

1950. (and Blankenship, R. R.). Subsurface geologic cross section from Claybrook, Madison County, to Memphis, Shelby County, Tennessee:

Tenn. Div. Geology Ground-Water Inv. Prelim. Chart 1.

The chart is based on logs of 10 wells and test holes. A text, printed on the chart, briefly describes test-drilling procedures used and discusses some of the stratigraphic problems and the criteria used to make correlations. Data include graphic logs, electric logs, 12 chemical analyses, and a table of geologic formations and their water-bearing properties.

1951. Review of "Grundwasserkunde," by W. Koehne: Jour. Geology, v. 59 , no. 4 , p. $408-410$.

Schoff, Stuart L. See also Laine, L. L., 51; Reed, E. W., 47, 52b, 55; Walling, I. W., 55.

1948. Ground-water irrigation in the Duke area, Jackson and Greer Counties, Oklahoma: Okla. Geol. Survey Min. Rept. 18, 8 p., 1 fig.

Irrigation wells yield as much as $1,700 \mathrm{gpm}$ near Duke. Some wells proved unsuccessful even though near wells of large production. Solution of gypsum in the Blaine formation is thought to have developed large openings which are partly filled by water descending through sinkholes. The large yields are obtained where wells penetrate the openings.

Data include 8 well records and 1 chemical analysis.

1949a. Ground water in Kingfisher County, Oklahoma: Okla. Geol. Survey Min. Rept. 19, 21 p., 1 fig.

Ground water for irrigation or other large-scale uses is available in the alluvium along the Cimarron River and in terrace deposits north of the river in Kingfisher County.

Data for the 900 -sq-mi county include 9 well records, 20 test-hole logs, and 12 chemical analyses.

1949b. Ground water at high stage in Oklahoma Panhandle: Okla. Geol. Survey Hopper, v. 8, no. 8, p. 74-76.

1950a. Ground water in the Cherokee area, Alfalfa County, Oklahoma: Okla. Geol. Survey Min. Rept. 21, 17 p., 1 fig.

Ground water adequate for municipal or other moderately large uses is available in terrace deposits and alluvium, but not all the water is of desirable quality.

Data include 4 chemical analyses.

1950b. Geology and water-well construction: Am. Water Works Assoc. Jour., v. 42, no. 5, p. 475-478.

Geologic data on thickness, character, and structure of rock formations, 
and on the movement of water in them are basic to the preparation of contracts for water wells.

1951a. Measurements-How made, how used: U. S. Geol. Survey dupl. rept., $4 \mathrm{p}$.

Methods of measuring well depth and diameter, height of measuring point, depth of water, and discharge are described briefly.

1951b. (and Reed, E. W.). Ground-water resources of the Arkansas River flood plain near Fort Gibson, Muskogee County, Oklahoma: Okla. Geol. Survey Circ. 28, 55 p., 12 pls., 1 fig.

The Fort Gibson flood plain includes $10 \mathrm{sq} \mathrm{mi}$ of Arkansas River bottom land. Enough water is stored in the sediments to sustain irrigation or other large uses during several drought years.

Data include 37 test-hole $\operatorname{logs}, 5$ well $\operatorname{logs}, 28$ chemical analyses, particlesize analyses, and a fence diagram. Data are given for 3 aquifer tests of the alluvium. A map (scale about 1:24,000) shows water levels and bedrock surface.

1951c. (and Reed, E. W.). Ground water in alluvial deposits in Oklahoma: Econ. Geology, v. 46, no. 1, p. 76-83, 3 figs.

Results of aquifer tests of alluvium in Oklahoma indicate that moderately large sustained yields may be expected generally. Tests in the North Canadian River valley near Oklahoma City and El Reno yielded surprisingly similar values for transmissibility, and these were only 14 percent less than that in the Arkansas River valley at Fort Gibson.

1953. Ground-water pumpage and water levels in the Oklahoma Panhandle: Okla. Geol. Survey. Hopper, v. 13, nos. 9-12, p. 51-57.

In the Oklahoma Panhandle, a thick deposit of sediments, largely unconsolidated, forms one of the largest reservoirs of ground water in Oklahoma. So far, pumping appears not to have made an appreciable dent in the groundwater supply, but replenishment is not enough for the entire panhandle to be irrigated indefinitely.

1955. Map showing ground-water reservoirs in Oklahoma: Okla. Geol. Survey Map 72-2.

Map shows distribution of the fresh-water aquifers, depth to water, and yields that can be expected (scale about 1:750,000).

\section{Schreurs, Raymond L.}

1954. Configuration of the water table in Nebraska: U. S. Geol. Survey Hydrol. Inv. Atlas HA 4.

Contour map of the water table indicates the direction of movement of ground water and the position of ground-water divides between streams.

Schroeder, Melvin C. See also Hoy, N. D., 52; Parker, G. G., 55d.

1954a. (and Klein, Howard). Geology of the western Everglades area, southern Florida: U. S. Geol. Survey Circ. 314, 26 p., 3 figs.

The lithology and paleontology are logged for cores from a series of 43 test holes $30 \mathrm{ft}$ deep. Four cross sections show the geologic interpretation of the data discussed in the report. The holes are on a line on the western edge of the Everglades from the Tamiami Canal northward to the Caloosahatchee River. Lack of outcrops in the area makes these cores important as a source of geologic data. The materials penetrated by the test holes range from Quaternary organic soils and the Lake Flirt marl to the late Miocene 
Tamiami formation. In the eastern part of this area the Tamiami is of low permeability and the younger, overlying Fort Thompson formation constitutes the principal part of the permeable Biscayne aquifer of the Everglades and the Miami area. West of the line of test holes the Biscayne aquifer disappears and the eastern part of the Big Cypress Swamp is underlain by materials of relatively low permeability. These materials have a shallow water table and they have only slight capacity for absorbing and carrying off floodwaters underground.

1954b. (and Milliken, D. L., and Love, S. K.). Water resources of Palm Beach County, Florida: Fla. Geol. Survey Rept. Inv. 13, 63 p., 21 figs.

The principal aquifer is composed of the surface sands and the permeable limestone and shell beds underlying them. In 1951 an average of $22 \mathrm{mgd}$ was withdrawn from this aquifer. The Floridan aquifer of Eocene, Oligocene, and Miocene limestones yields artesian water containing 3,000 to 4,000 ppm of dissolved solids.

Data for the 1,978-sq-mi county include a well-location map, a water-level map of the Lake Worth area, 10 chemical analyses of ground-water samples, 2 geologic cross sections, and results for aquifer tests of the shallow aquifer at Delray Beach.

Searcy, J. K.

1952. (and Baker, R. C., and Durum, W. H.). Water resources of the St. Louis area, Missouri and Illinois: U. S. Geol. Survey Circ. 216, 55 p., 1 pl., 31 figs.

Present use is about $1,300 \mathrm{mgd}$, or less than 1 percent of the estimated potential supply. A map shows the bedrock surface in the American Bottoms and areas where large quantities of ground water may be developed. Logs of four wells in the alluvium are given. The principles of induced infiltration are discussed and the possibilities of greater application are evaluated. The public water supplies are described. Tables and graphs showing the chemical quality and temperature of water from ground and. surface sources and from the public supplies are presented. Laws affecting the use of water in the area are described briefly and the water-resources potential of the area is summarized.

\section{Shuter, Eugene}

1953. Records of wells and water-level fluctuations in western Bingham County, Idaho: U. S. Geol. Survey dupl. rept., 99 p., 1 pl., 1 fig.

Data for the 900-sq-mi area include 207 well records, 4 test-hole logs, 12 well logs, and discharge measurements.

Simons, Edward T. See Reck, C. W., 52.

Simons, W. D.

1953. Spokane-Coeur d'Alene River basin, Washington-Idaho, in Subsurface facilities of water management and patterns of supply-Type area studies: U. S. Cong., House Comm. Interior and Insular Affairs, Phys. and Econ. Found. Nat. Res., v. 4, chap. 10, p. 162-185, 26 figs. Overall water supply is adequate, but means are needed to regulate the highly variable natural water yield.

\section{Simpson, Eugene S.}

1949. Buried preglacial ground-water channels in the Albany-Schenec- 
tady area in New York: Econ. Geology, v. 44, no. 8, p. 713-720, 2 figs; reprinted as N. Y. Water Power and Control Comm. Bull. GW-20A, 1949.

A buried channel of the preglacial Mohawk River, with its tributaries, is mapped from Schenectady to its confluence with the Hudson River 12 miles south of Albany. Permeable deposits in the buried channels are important aquifers in the area.

1952. The ground-water resources of Schenectady County, New York:

N. Y. Water Power and Control Comm. Bull. GW-30, 110 p., 2 pls., 31 figs.

Although ground water may be obtained from both the bedrock and surficial deposits in the county, large supplies can be pumped only from sands and gravels in the surficial deposits; the bedrock, mostly shale, is dense and has comparatively few openings. Some wells in gravel along the Mohawk River yield more than 3,000 $\mathrm{gpm}$, whereas the average yield of wells in bedrock is less than $25 \mathrm{gpm}$. The yield of wells in bedrock is shown to be related to the type of overburden. Temperature of equilibrium is defined (p. 82), and theoretical temperatures of induced recharge from the Mohawk River to a nearby well field are compared with recorded ground-water temperatures.

Data for the 209-sq-mi county include 300 selected well records, 58 well logs, a 21-year well hydrograph, particle-size analyses, 55 comprehensive chemical analyses, 1 complete chemical analysis, measurements of ground water temperature, and results for an aquifer test of gravel in the Mohawk Valley at Schenectady. Maps show bedrock surface (scale about 1:125,000), surficial deposits (scale about 1:300,000), and bedrock geology (scale 1:125,$000)$. The latter two maps are based on existing sources.

\section{Simpson, Thomas A.}

1955. Mining hydrology problems in the Birmingham red iron ore district: Min. Eng., v. 7, no. 1, p. 1-4, 5 figs.

Reviews hydrologic history of mining the red iron ore and outlines the nature of current studies. A table summarizes the geology and hydrology of the Paleozoic rocks in the Birmingham district. A geologic cross section shows water levels in the district.

Sinnott, Allen. See also Poland, J. F., 48.

1950. (and Whetstone, G. W.). The occurrence of fluoride in the ground waters of the Virginia Coastal Plain: Am. Chem. Soc. Bull. Va. Sects., v. 28, no. 2, p. 45-50.

The presence of fluoride in the ground water is believed to be due to the action of soft sodium bicarbonate water on certain clays and micas and to the action of extremely dilute sulfuric acid, formed by the decomposition of pyrite, on fluoride-bearing minerals such as tourmaline. In Virginia the average concentration of fluoride is $0.1 \mathrm{ppm}$ in water from Pleistocene deposits, $0.6 \mathrm{ppm}$ from Miocene deposits, $1.7 \mathrm{ppm}$ from Eocene deposits, 2.7 ppm from Cretaceous deposits, and $0.1 \mathrm{ppm}$ in surface streams.

1952. Ground-water conservation; a brief bibliography: Reading Guide, Law Library of the Univ. Virginia, v. 7, no. 2, p. 27-28.

Suggests that an adequate, comprehensive system of water law is needed which will apply to all phases of the hydrologic cycle. Nine publications are cited. 
1954. (and Tibbitts, G. C., Jr.). Summary of geology and ground-water resources of the Eastern Shore peninsula, Virginia; a preliminary report: Va. Div. Geology Min. Res. Circ. 2, 18 p.

Test drilling indicates that, except on Tangier Island, the likelihood of finding suitable water-bearing sands below $300 \mathrm{ft}$ is remote, and that the chemical quality of water is likely to be unsuitable for most uses. Most of the wells of larger yield are 80 to $300 \mathrm{ft}$ deep, and up to $250 \mathrm{gpm}$ should be obtainable from individual 6-inch wells tapping more than one aquifer within this depth range.

1955. (and Tibbitts, G. C., Jr.,). Records of selected wells on the Eastern Shore peninsula, Virginia, including well logs and chemical analyses of ground water: Va. Div. Geology Min. Res. Circ. 3, 39 p., 3 figs.

Data include 130 well records, 4 test-hole logs, 48 well logs, and 60 chemical analyses.

Siple, G. E.

1946. Progress report on ground-water investigation in South Carolina:

S. C. Research, Planning, and Devel. Board Bull. 15, 116 p., 10 pls., 4 figs.

Discusses geology and ground-water occurrence in the Piedmont and Coastal Plain provinces. Data include 741 well records, 117 chemical analyses, and 3 geologic cross sections. A geologic map is adapted from existing sources.

\section{Sisco, Harold G.}

1954. Records of wells, water-level fluctuations, and ground-water withdrawals in the Aberdeen-Springfield area, Bingham and Power Counties; Idaho: U. S. Geol. Survey dupl. rept., 50 p., 1 pl., 1 fig.

Data for the 275 -sq-mi area include 78 well records, 24 well $\operatorname{logs}$, waterlevel measurements, and a summary of ground-water withdrawals in 1953.

1955. Records of wells and water-level fluctuations in the AberdeenSpringfield area, Bingham and Power Counties, Idaho, in 1954: U. S. Geol. Survey dupl. rept., 30 p., 1 pl., 3 figs.

Data include records of 28 observation wells and periodic water-level measurements.

Skibitzke, Herbert E. See Jones, P. H., 54b; Turner, S. F., 52.

Slaughter, T. H. See Rasmussen, W. C., $55 \mathrm{~b}$.

Smith, Peter C. See Heath, R. C., 54b.

Smith, Robert C.

1953. The ground-water resources of Summit County, Ohio, with a section on glacial geology by G. W. White: Ohio Div. Water Bull. 27, 130 p., 22 pls.

The chief aquifers are sand and gravel in buried valleys under the Tuscarawas River and portions of the Cuyahoga River, and are capable of yielding large amounts of water. These aquifers are exposed at the surface and may be recharged by infiltration of streamflow.

Data for the 413-sq-mi county include more than 2,000 well records, and 1,500 graphic well logs, and 30 chemical analyses. Maps show ground- 
water areas (scale 1:62,500), bedrock surface and geology (scale 1:125,000), surficial geology (scale 1:125,000), and glacial deposits in northeastern Ohio (scale about 1:125,000.

1955. (and Doll, W. L., and Stratton, Garland). Water resources of the Wheeling-Steubenville area, West Virginia and Ohio: U. S. Geol. Survey Circ. 340, 31 p., 1 pl., 21 figs.

In 1950 about $950 \mathrm{mgd}$ of water was used daily in the area. This amount is about $3 \frac{1 / 2}{2}$ percent of the average flow of the Ohio River at this point and 36 percent of the flow that is equaled or exceeded 99 percent of the time. The water-bearing properties of the important geologic formations are described, and the relation among water levels, precipitation, and river levels is illustrated. Tables and graphs show the chemical quality and temperature of water from ground and surface sources. The public water-supply systems in the area are described and chemical analyses of the water from several are given. Laws affecting the use of water in the area are described briefly and the water-resources potential is evaluated.

Smith, W. O.

1949. Pedological relations of infiltration phenomena: Am. Geophys. Union Trans., v. 30 , no. 4 , p. 555-562, 9 figs.; discussion by W. B. Langbein, v. 30 , no. 4, p. 562, 1949 ; discussion by W. C. Rasmussen, v. 32, no. 2, p. 282, 1951; closing discussion by W. O. Smith, v. 32, no. 2, p. 282-283, 1951.

Not only overall porosity but its division into textural and structural pore space is important in affecting infiltration. The initial moisture content also is significant.

1955. (and Stallman, R. W.). Measurement of permeabilities in groundwater investigations, with a discussion by A. L. Johnson, in Symposium on permeability of soils: Am. Soc. Testing Materials Special Tech. Pub. 163, p. 98-122, 17 figs.

A piston-type sampling device has been developed for obtaining undisturbed samples. An inner barrel, in which an undisturbed sample is taken, is removed and used as the permeameter tube in subsequent tests.

The techniques for permeability measurement are described, including the effects of trapped air or other gases.

\section{Sniegocki, Richard T.}

1955. Ground-water resources of the Prairie Creek unit of the lower Platte River basin, Nebraska, with a section on chemical quality of ground water by F. H. Rainwater: U. S. Geol. Survey Water-Supply Paper 1327, 133 p., 8 pls., 12 figs.

The chief aquifer is a sheetlike deposit of Pleistocene sand and gravel. In about three-fourths of the area, the water table is less than $10 \mathrm{ft}$ below the land surface. Pumping from the 900 irrigation wells in the unit has not yet depleted the local ground-water supply. A typical irrigation well in the unit is less than $75 \mathrm{ft}$ deep and yields 500 to $1,000 \mathrm{gpm}$.

The Prairie Creek unit is a triangular area bounded on the north by the Loup River, on the southeast by the Platte River, and on the west by the Merrick County line. The 650-sq-mi area includes almost all of Merrick County, about a fourth of Nance County, and small parts of Platte and Howard Counties. Data include 284 well records, 68 test-hole logs, 20 soil 
analyses, 39 chemical analyses, and determinations of physical and hydrologic properties of sediments. Maps show water levels, depth to water, saturated thickness, and top of Cretaceous bedrock.

Snyder, C. T, See Babcock, H. M., 47c.

\section{South Carolina Development Board}

1955. Water resources, in Resources of South Carolina: Bull. 22, p. 3453 , pls. 7 and 11.

Well depths, well yields, and water quality are summarized for each of the 46 counties.

\section{Spicer, H. Cecil}

1952. Electrical-resistivity studies of subsurface conditions near Antigo, Wisconsin: U. S. Geol. Survey Circ. 181, 19 p., 23 figs.

Describes a resistivity study of the glacial-outwash deposits near Antigo, Wisconsin, to determine thickness of sand and gravel deposits and presence of underlying till and older outwash deposits. The results are presented both as cross sections and as contour maps. The apparent-resistivity curves, their interpretation in terms of the thickness and character of the geological materials, and 4 well logs are given.

1955. Electrical-resistivity studies, in Water resources of southeastern Florida: U. S. Geol. Survey Water Supply Paper 1255, p. 712-725, pl. 18, figs. 203-212.

In the coastal area near Miami and Fort Lauderdale, salty ground water can be located by resistivity methods, but sites for measurements must be selected carefully.

\section{Spiegel, Zane}

1955. Geology and ground-water resources of northeastern Socorro County, New Mexico: N. Mex. Bur. Mines and Min. Res. GroundWater Rept. 4, 99p., 2 pls., 8 figs.

The chief aquifers in the area, the Santa Fe formation of Tertiary age and alluvium of Quaternary age, occur principally in the Rio Grande graben. The Santa Fe formation generally is favorable for the development of wells yielding more than $100 \mathrm{gpm}$; the alluvium is even more productive. Except for the Rio Grande there are no perennial streams for stock or irrigation use. In the higher areas, Precambrian rocks yield small amounts of water of fair quality. Pennsylvanian rocks yield somewhat larger supplies of hard water and Permian rocks generally yield supplies sufficient for stock. The Yeso and San Andres formations yield water generally unfit for domestic use because of sulfate content. Triassic and Cretaceous rocks are poor aquifers because of low permeability and high mineralization. Ground-water supplies in quantities sufficient for irrigation use are available mainly from alluvium along the inner valley of the Rio Grande and in favorable areas from the Santa Fe formation. However, withdrawal and consumptive use of ground water from wells in the alluvium and Santa Fe formation will result in eventual decrease in flow of the Rio Grande. Water levels in wells were used to infer the locations of important faults in the Rio Grande trough. Discharge records of the Rio Puerco were used to estimate amounts of recharge to the Santa Fe formation from one important source.

Data include 124 well and 18 spring records and 51 chemical analyses. Maps show areal geology (scale 1:125,000)", ground-water areas, and water levels. 
Stafford, Harlow M. See also Troxell, H. C., 49.

1953. (and Troxell, H. C.). Coastal basins near Los Angeles, California, in Subsurface facilities of water management and patterns of supplyType area studies: U. S. Cong., House Comm. Interior and Insular Affairs, Phys. and Econ. Found. Nat. Res., v. 4, chap. 2, p. 21-50, 29 figs.

Describes the elements of the water situation, including precipitation, natural water losses, runoff, supply capability of ground water, the net local water supply, and water requirements. Two major problems, the groundwater overdraft and ocean-water encroachment, are discussed, and the potential refinements in development of the local water sources are indicated.

Stallman, Robert W. See also Klaer, F. H., 48b; Smith, W. O., 55; Stuart, W. T., $45 \mathrm{~b}$.

1950. (and Klaer, F. H., jr.). Ground-water resources of Noble County, Indiana: Ind. Dept. Conserv., Div. Water Res. Bull. 5, 103 p., 5 pls., 8 figs.

Sand and gravel deposits of glaciofluvial origin are the chief aquifers. Average recharge is $150 \mathrm{mgd}$ and average ground-water pumpage is $5 \mathrm{mgd}$. Large supplies of ground water can be developed in outwash valleys in the western part of the county.

Data for the 420 -sq-mi county include 320 well records, 32 well logs, partial chemical analyses, and results for aquifer tests of sand and gravel at Kendallville. Maps show water levels and surficial geology (scale about $1: 130,000)$.

1952. Revision of a 1937 paper, "Apparatus for testing the permeability of samples of unconsolidated sediment in the field," by V. C. Fishel and V. T. Stringfield: U. S. Geol. Survey dupl. rept., 8 p., 2 figs.

Describes construction, use, and limitations of the variable-head field permeameter, with a sample-barrel length of 14.5 centimeters and an inside diameter of 3.5 centimeters.

Stanley, George M. See Stuart, W. T., 48.

\section{Stearns, Harold T.}

1946. (and Macdonald, G. A.). Geology and ground-water resources of the Island of Hawaii: Hawaii Div. Hydrography. Bull. 9, 363 p., 54 pls., 6 figs.

The volcanic rock of the island is highly permeable and most rainfall sinks quickly into the ground. Most infiltration recharges the basal water table, where a fresh water lens floats on salt water. Along the windward coasts the basal water is of good quality, but along the leeward coasts most of the basal water is brackish.

Data for the 4,030-sq-mi island include 22 well records, chloride determinations, 20 chemical analyses, discharge measurements of wells, springs and tunnels, and an areal geologic map (scale 1:125,000).

1947. (and Macdonald, G. A.). Geology and ground-water resources of the Island of Niihau, Hawaii; Petrography of Nihau: Hawaii Div. Hydrography Bull. 12, 53 p., 5 pls., 8 figs.

The island will always be short of domestic water because of aridity, unfavorable geologic structure, continuous deposition of salt spray, and salt deposited concurrently with sediments in lake beds. 
Data for the 72-sq-mi island include 57 well records, chloride determinations, and an areal geologic map (scale 1:62,500).

Stearns, Richard G.

1955. (and Armstrong, C. A.). Post-Paleozoic stratigraphy of western

Tennessee and adjacent portions of the upper Mississippi Embayment:

Tenn. Div. Geology Rept. Inv. 2, 29 p., 15 pls., 2 figs.

The Upper Cretaceous, Paleocene, and Eocene beds of the upper Mississippi Embayment are subdivided into five units based on interpretation of electric $\operatorname{logs}$ of wells. Illustrations include 5 electric-log cross sections, a geologic fence diagram, maps of thickness and sand distribution for each of the 5 units, and maps showing top of the Paleozoic rocks, top of the Cretaceous system, and base of the " $500-\mathrm{ft}$ " sand.

Stewart, Joseph W.

1954. (and Nace, R. L., and Deutsch, Morris). Preliminary report on ground water in the Michaud Flats project, Power County, Idaho:

U. S. Cong., 83d, 2d Sess., H. Doc. 485, p. 55-77, 2 pls., 2 figs.

The possibility was investigated of developing substantial quantities of ground water for irrigating high and outlying lands in the proposed Michaud Flats project area. Initial findings are sufficiently favorable to warrant a comprehensive further investigation which is outlined.

Data for the 65-sq-mi area include 81 well records, 9 well logs, and a waterlevel map.

Stramel, G. J. See also Ferris, J. G., 54; Wisler, C. O., 52.

1951. Ground-water resources of Parker County, Texas: Tex. Board Water Engineers Bull. 5103, 55 p., 1 pl.

Sands in the Trinity group are the chief aquifers.

Data for the 904-sq-mi county include 340 well records, 69 well logs, 129 chemical analyses, and a geologic map (scale about 1:130,000).

1954. (Wisler, C. O., and Laird, L. B.). Water resources of the Grand Rapids area, Michigan: U. S. Geol. Survey Circ. 323, 40 p., 3 pls., 29 figs.

The report contains information on the quantity and quality of water in 12 townships of Kent County, Michigan, and describes the aquifers. The principle of induced infiltration is discussed. Tables and graphs show the chemical quality and temperature of water from ground and surface sources including Lake Michigan. The public water-supply systems are described and the source and quality of the water served are given. Laws affecting the use of water in the area are described briefly, and the water-resources potential of the area is evaluated. Maps show bedrock geology, glacial geology, and bedrock surface (scale about 1:125,000).

Strand, Jesse R. See Mundorff, M. J., 52.

Stratton, Garland. See Smith, R. C., 55 .

Stringfield, V. T. See also Cooper, H. H., Jr., 50; Parker, G. C., 50; Sayre, A. N., $48 \mathrm{c}$.

1950. Ground-water geology in the southeastern States, in Snyder, F. G., ed., Symposium on mineral resources of the southeastern United States: Knoxville, Univ. Tenn., p. 211-222, 3 figs. 
Describes characteristics of the four ground-water provinces in the southeastern United States: South-central Paleozoic, Blue Ridge-Appalachian Valley, Piedmont, and Coastal Plain. General data on ground-water investigations and use in the region are included.

1951a. (and Cooper, H. H., Jr.). Geologic and hydrologic factors affecting perennial yield of aquifers: Am. Water Works Assoc. Jour., v. 43 , no. 10, p. 803-816, 4 figs.

Determining perennial yield is among the most urgent problems in development and use of ground water. The term capture is proposed (p. 806) for water obtained through decrease in natural discharge or increase in recharge resulting from pumping.

1951b. (and Cooper, H. H., Jr.). Economic aspects of ground water in Florida: Min. Eng., v. 3, no. 6, p. 525-533, 5 figs.

Estimated use of ground water in Florida is $177,000 \mathrm{mgy}$. Maps of Florida show water levels, areas of artesian flow, chloride content of ground water, and top of Ocala limestone.

1951c. (and Cooper, H. H., Jr.). Geologic and hydrologic features of an artesian submarine spring east of Florida: Fla. Geol. Survey Rept. Inv. 7, p. 58-72, 6 figs.

The submarine spring $21 / 2$ miles east of Crescent Beach, Fla., is an example of discharge from the principal artesian aquifer (Eocene, Oligocene, and Miocene limestones) into the Atlantic Ocean. Water feeding the spring enters the aquifer about 50 miles to the west. The relatively high chloride content of the water (estimated $4,000 \mathrm{ppm}$ ) represents a mixture of meteoric water with sea water that entered the aquifer during Pleistocene time.

1953. Artesian water in the southeastern States: Ky. Geol. Survey Special Pub. 1, p. 24-39, 4 figs.

The history of exploration for artesian water is reviewed. The main artesian aquifers in the southeastern States are described and the source, movement, chemical quality, temperature, yield, and use of their waters are briefly summarized.

A map (scale about $1: 11,000,000$ ) shows areas of artesian flow in the southeastern States.

Stuart, Wilbur T. See also Brown, E. A., 51.

1945a. Ground-water resources of the Lansing area, Michigan: Mich. Geol. Survey Div. Progress Rept. 13, 33 p., 11 figs.

Heavy pumping has lowered water levels locally and induced infiltration from below of waters of greater hardness and sulfate content.

Data for the 308-sq-mi area include a water-level map and results for aquifer tests of Pennsylvanian sandstone at Lansing.

1945b. (and Stallman, R. W.). Ground-water resources of the Benton Harbor area, Michigan: Mich. Geol. Survey Div. Prog. Rept. 12, 15 p., 4 figs.

In the municipal well field about $3 \mathrm{mgd}$ of ground water can be pumped continuously without serious water-level decline. Additional supplies may be developed south of Benton Harbor at sites where sand and gravel have sufficient transmissibility to support large yields from wells.

Data include 65 well records, 36 well $\log$ s, and results for aquifer tests of glacial sand and gravel. 
1948. (and Theis, C. V., and Stanley, G. M.). Ground-water problems of the Iron River district, Michigan: Mich. Geol. Survey Div. Tech. Rept. 2, 59 p., 16 figs.

Water, which in some places saturates the glacial overburden to a depth of $200 \mathrm{ft}$ or more, apparently seeps into the underlying iron formation and follows the formation to the mine opening within it. In some places where mining is done by caving methods, the stoping extends upward, breaking the ground and increasing downward percolation of ground water. In a steeply inclined contorted aquifer, larger amounts of water will move to lower, as opposed to upper, openings, but the tendency is modified or reversed by competing openings in the same geologic structure, by folds and degree of inclination of the strata, by the topography of the bedrock surface, and by depth of saturation in the overburden.

Considerable theory is developed and applied in this report. The flow of ground water in vertical and steeply inclined aquifers is studied mathematically. The relations among drawdown, yield, and well diameter are studied. A theory of movement of ground water into mines is advanced and investigations of recharge are described. Data include seepage measurements, 34 chemical analyses, a water-level map, a glacial-deposits map, and a bedrock-surface map (all at scale of about 1:50,000).

1951. Mine-drainage studies in the iron ranges of northern Michigan: Min. Eng., v. 3, no. 12, p. 1101-1104; Am. Inst. Min. Metall. Eng. Trans., v. 190, 1952.

Some mining properties may be effectively dewatered by pumping from the overburden. In others where surface pumping is not economical, properly located water-interception drifts may control the water so that a drier ore may be mined with fewer hazards and at less cost. However, no one method or combination of methods can be applied economically to eliminate all the ground water in mine workings. Each problem requires separate study and solution.

1954. (Brown, E. A., and Rhodehamel, E. C.). Ground-water investigations of the Marquette iron-mining district, Michigan: Mich. Geol. Survey Div. Tech. Rept. 3, 92 p., 8 figs.

Maximum reduction of water level in critical areas requires unwatering devices to be located close to those areas. A system of cheaply constructed wells near collapsed areas, even though they may be lost eventually through further collapse, may be more economical as an unwatering device than larger wells of greater capacity located at some distance from the collapse area. Because flow of water into the bedrock varies approximately as the saturated thickness in the overburden, the flow of water into the bedrock below can be controlled by pumping from the overburden.

Data for the 168-sq-mi area include 25 chemical analyses, 81 laboratory coefficients of permeability for rock formations in Lake Superior district, results for aquifer tests of glacial overburden, discharge measurements, and pumpage figures. A uniform-rate discharge test is described. Maps (all at scale of $1: 31,680$ ) show water levels, bedrock surface, and surficial geology.

1955. Pumping test evaluates water problem at Eureka, Nevada: Min. Eng., v. 7, no. 2, p. 148-156, 15 figs.; Am. Inst. Min. Metall. Eng. Trans., v. 202.

In 1952, a 30-day aquifer test near Eureka, Nevada, provided an oppor- 
tunity to gain knowledge of ground-water movement around a flooded mine shaft. The methods of analyzing the data may be used as a guide for the evaluation of similar problems elsewhere. Water is yielded chiefly by the Eldorado dolomite.

Subitzky, Seymour. See also Cederstrom, D. J., 53.

1955. Summary of geology and ground-water conditions in the Fredericksburg district, eastern Spotsylvania County, Virginia: Va. Div. Geology Min. Res. Circ. 4, 32 p., 4 figs., 2 pls.

Rocks of pre-Cretaceous, Cretaceous, and Tertiary age yield small to moderate amounts of water to wells. Shallow wells yield water low in dissolved mineral constituents but locally may yield water containing objectionable amounts of iron. Deeper wells yield water that contains less than $\mathbf{5 0 0}$ ppm of dissolved solids, but most of the water has a slight hydrogen-sulfide odor and contains undesirable quantities of iron. A few wells drilled deeper than 400 feet into the basement complex have been reported to yield salty water.

Data for the 31-sq-mi area include records of 112 wells, logs of 25 wells and test holes, and 15 chemical analyses.

Sundstrom, Raymond W. See also Broadhurst, W. L., 50b, 51b.

1947. Conservation of ground-water supplies in Texas: Tex. Board Water Engineers dupl. rept., 6 p.

An address given before the Fourth Annual Meeting of the Capitol Area Water and Sanitation Association.

1948a. Ground-water resources in the southern region of Texas: Tex. Board Water Engineers dupl. rept., 3 p., 1 pl.

An address given at the Governor's South Texas water conference.

1948b. Results of pumping tests on the city wells at Waxahachie, Texas:

Tex. Board Water Engineers dupl. rept., 7 p., 1 fig.

Future drawdowns are predicted for several pumping rates and several periods of time. The aquifer tested was sand of the Trinity group.

1948c. (and Hastings, W. W., and Broadhurst, W. L.). Public water supplies in eastern Texas: U. S. Geol. Survey Water-Supply Paper 1047, 285 p., 1 fig.

Describes the public water supplies for 323 communities in 77 counties of eastern Texas, extending from the Louisiana boundary to a north-south line approximately along the 97 th meridian. Of the 323 public supplies, 273 use ground water. The use of water for public supply averaged $157 \mathrm{mgd}$, of which $92 \mathrm{mgd}$ was ground water.

Data include population, name of the official from whom the information was obtained, ownership of waterworks, source of supply, amount of water consumed, facilities for storage, number of customers served, character of chemical and sanitary treatment, and chemical analysis of the water. Where ground water is used, the following also are given: records of wells, drillers' $\log \mathrm{s}$, character of pumping equipment, yield of wells, and records of water levels.

1949a. (and Broadhurst, W. L., and Dwyer, B. C.). Public water supplies in central and north-central Texas: U. S. Geol. Survey WaterSupply Paper 1069, 128 p., 1 pl.

Describes the public water supplies for 145 communities in 53 counties of 
central and north-central Texas, extending from the southern boundaries of Travis, Blanco, Gillespie, and Kerr Counties northward to the Texas-Oklahoma State line. Of the 145 public supplies, 94 use ground water. The use of water averaged $79 \mathrm{mgd}$, of which $18.5 \mathrm{mgd}$ was ground water.

For type of data included, see Sundstrom 48a.

1949b. (Cromack, G. H., and West, N. N.). Ground-water resources of Matagorda County, Texas: Tex. Board Water Engineering dupl. rept., 38 p., 2 figs.

Data for the 1141-sq-mi county include 230 well records, 68 well logs, and 22 comprehensive and 12 partial chemical analyses. A geologic map (scale about 1:900,000) is based on the 1937 geologic map of Texas.

1950. (and Follett, C. R.). Ground-water resources of Atascosa County, Texas: U. S. Geol. Survey Water-Supply Paper 1079-C, p. 107-153, pl. 2.

Atascosa County is underlain by water-bearing sands, the most productive of which is the Carrizo sand. Substantial supplies are obtained also from the Mount Selman and Cook Mountain formations. The rate of withdrawal from the Carrizo sand in the county amounted to 15,500 acre-ft in the year 1944-45. Of this, about 6,500 acre-ft a year was largely wasted from uncontrolled flowing wells. If the waste of water from wells in the Carrizo sand were stopped, the consumption of water for useful purposes could be increased about 70 percent without increasing the draft on the underground reservoir. Between $1929-30$ and 1944, increasing withdrawal from the Carrizo sand was accompanied by a decline in artesian head ranging from 3 to $25 \mathrm{ft}$. On the whole, the artesian reservoir is not being overdrawn and will sustain a somewhat greater draft.

Data for the 1206-sq-mi county include 307 well records, 15 well logs, and 20 comprehensive and 75 partial chemical analyses.

1952a. Ground water for irrigation at the Federal Correctional Institution, La Tuna, Texas: Tex. Board Water Engineers dupl. rept., 11 p., 2 figs.

Adequate ground water is available for supplemental irrigation. Wellspacing requirements are outlined and probable drawdowns from pumping are predicted.

Data include 32 well records, 1 chemical analysis, and results for an aquifer test of alluvium in the Rio Grande valley.

1952b. (and Hood, J. W.). Results of artificial recharge of the groundwater reservoir at El Paso, Texas: Tex. Board Water Engineers Bull. 5206, 19 p., 7 figs.

Surface water could be injected into 4 wells in the Montana well field at El Paso at a rate of $6 \mathrm{mgd}$. In the Mesa well field the injection rate could be many times higher. Experimental artificial recharge caused a reduction of the chloride content in a recharge well, indicating that recharge 'might retard or even halt the encroachment of salty water.

Aquifer-tests of the bolson deposits were used to determine coefficients used in computing effect of artificial recharge.

1954. The outlook for ground-water resources in Texas: Tex. Board Water Engineers dupl. rept., 20 p., 12 figs.

Ground-water use and outlook are summarized for the High Plains and the Houston, San Antonio, and El Paso areas. Maps show water-level de- 
cline in the southern High Plains (1953-54), water levels in the Houston area, and altitude of base of fresh-water sands in Harris County.

1955. Ground-water resources in Texas: Am. Water Works Assoc. Jour., v. 47 , no. 7, p. 695-702.

In 1953 more ground water was used in Texas than in any other State except California. Ground-water use was 7 million acre-ft. Problems of ground-water supply in the High Plains and the Houston, San Antonio, and El Paso areas are outlined.

Swartz, B. W.

1954. Records of water-level measurements in Atascosa and Frio Counties, Texas: Tex. Board Water Engineers Bull. 5416, 24 p., 4 figs.

Periodic measurements of depth to water are given for 50 wells in Atascosa County and 24 wells in Frio County.

Swenson, Frank A. See also Lorenz, H. W., 51; Torrey, A. E., 51.

1948. Geology and ground-water resources of Iwo Jima: Geol. Soc. America Bull., v. 59, no. 10, p. 995-1008, 2 pls., 2 figs.

Iwo Jima consists of two volcanic cones connected by an undulating isthmus. The most favorable area for ground-water development is the isthmus. Ground water is somewhat mineralized and its temperature ranges from $105^{\circ}$ to $179^{\circ} \mathrm{F}$.

Data include 20 well records, 7 chemical analyses, and a lithologic map (scale about 1:60,000).

1951. (and Bach, W. K.). Ground-water resources of the Paintrock irrigation project, Wyoming, with a section on quality of water by H. A. Swenson: U. S. Geol. Survey Circ. 96, 45 p., 1 pl., 6 figs.

Lands that are irrigated or that are proposed for irrigation in the Paintrock irrigation project, in Big Horn County in north-central Wyoming, consists of flat to gently sloping stream terraces and alluvial bottoms along Nowood, Paintrock, and Medicine Lodge Creeks. The unconsolidated sediments that underlie these lands contain ground water at shallow depth but are progressively finer grained and less permeable to the west. The bedrock formations that underlie the area are folded into north-ward-trending anticlines and synclines. The 10 different aquifers in the bedrock formations, which may be reached at shallow depth only in relatively narrow belts of land that parallel the axes of the folds, differ widely in potential yield and in the quality of the water that they produce. In general, supplies from both the bedrock and the alluvium and terrace deposits are adequate for domestic and stock needs but not for large-scale irrigation.

Data for the 50-sq-mi area include 53 well records, periodic water-level measurements, discharge records, chemical analyses of 7 ground-water and 3 surface-water samples, and a geologic map (scale 1:63,360).

1953. Ground water in Montana: U. S. Geol. Survey dupl. rept., 7 p.

Emphasizes that ground water is a renewable resource and that failure to use it is not conservation but just a lost opportunity.

1955. Geology and ground-water resources of the Missouri River valley in northeastern Montana, with a section on quality of the ground water by W. H. Durum: U. S. Geol. Survey Water-Supply Paper 1263, 128 p., 1 pl., 18 figs.

The chief bedrock aquifers are in the Judith River formation, Fox Hills 
sandstone, Hell Creek formation, and Fort Union formation. Most domestic supplies are obtained from alluvial deposits, beds of gravel or coarse sand in the deeper parts of the alluvial fill of valleys in bedrock being especially productive.

Data for the area of about 1,000 sq mi include 1,019 well records, 10 testhole logs, 13 well logs, 2 measured sections, 21 chemical analyses, and an areal geologic map (scale 1:96,000).

\section{Swenson, Herbert A.}

For sections on chemical quality of waters in:

Angostura irrigation project, South Dakota, see Littleton, 49.

Fort Berthold Indian Reservation, North Dakota, see Dingman, 54a. Gillette area, Wyoming, see Littleton, 50a.

Heart River irrigation project, North Dakota, see Tychsen, 50.

Helena Valley, Montana, see Lorenz, 51.

Lower Platte River Valley, Nebraska, see Waite, 49.

Lower Yellowstone River Valley, Montana, see Torrey, 51.

Paintrock Irrigation project, Wyoming, see Swenson, F. A., 51.

Republican and Frenchman River Valleys, Nebraska, see Waite, 48b.

1953. Geochemical relationships of water in the Powder River basin, Wyoming and Montana: Am. Geophys. Union. Trans., v. 34, no. 3, p. 443-448, 3 figs.

The composition and amount of dissolved solids in the Powder River are related to the geology. Mountainous areas of Precambrian rock contribute small quantities of soluble material, generally less than $50 \mathrm{ppm}$. Streams in upland country underlain by Tertiary sandstone and shale transport salts in concentrations of more than $2,000 \mathrm{ppm}$. The composition of mineral substances in the river water can be correlated with the outcrop of such rocks as granite, limestone, gypsum, and shale.

Swindel, George W., Jr. See LaMoreaux, P. E., 50c.

Tait, D. B. See also Counts, H. B., 55.

1953. (and Baker, R. C., and Billingsley, G. A.). The ground-water resources of Columbia County, Arkansas-A reconnaissance: U. S. Geol. Survey Circ. 241, 25 p., 1 pl., 6 figs.

Total ground-water use in Columbia County is about $3 \mathrm{mgd}$, of which 2.7 $\mathrm{mgd}$ is from the Sparta sand. The maximum optimum perennial yield from the Sparta sand cannot be estimated, but the decline in water level suggests that the optimum rate of pumping in the vicinity of Magnolia is about $\mathbf{3}$ mgd. The Sparta yields soft sodium bicarbonate water. Sediments of Quaternary age in the western part of the county might de developed as a source of fairly hard, moderately mineralized water.

Data for the 768-sq-mi county include 55 well and spring records, 16 well logs, and 37 chemical analyses. A map shows structure contours on the base of the Sparta sand.

Taylor, George C., Jr. See also Sayre, A. N., 51; Theis, C. V., 42.

1948. Geology and ground water of the Casablanca Basin, Chile: Econ. Geology, v. 43 , no. 8, p. 661-674, 4 figs.

The Casablanca Basin, which lies halfway between Santiago and Val- 
paraiso, is formed by the intersection of three small fault trenches with a fourth and larger trench. The basin contains alluvial fill of Pleistocene and Recent age that is water bearing. Recharge is from rainfall and by infiltration of runoff from the uplands. Present pumpage is about 8,000-11,000 cubic meters per day during the irrigation season. Estimates indicate that the pumpage can be safely increased to 20,000 cubic meters per day.

Data include 7 well logs, 17 well records, and a generalized geologic and topographic map (scale about 1:200,000).

1949a. Ground-water studies in Haiti, in Progress in Agriculture: Inst. Inter-Am. Affairs, Food Supply Div., p. 1-4.

A brief summary of ground-water reconnaissance in six areas of Haiti: (1) Cul-de-sac plain, (2) Gonaïves plain, (3) Jacmel-Meyer bench, (4) Arcahaie plain, (5) plaine des Moustiques, and (6) the Pine Forest region.

$1949 \mathrm{~b}$. Geology and ground water of the Azapa Valley, Province of Tarapacá, Chile: Econ. Geology, v. 44, no. 1, p. 40-62, 5 figs.

In the Azapa Valley of extreme northern Chile, the alluvial fill of Pleistocene and Recent age is the source of fresh ground water. The water table is generally within 25 meters of the land surface in the valley. During the irrigation season of 1946-47, the irrigational use of ground water was 15,000 cubic meters per day, and the city of Arica used an additional 1,700 cubic meters per day.

Included are 4 measured sections, 2 geologic cross sections, 25 partial and comprehensive chemical water analyses, a generalized geologic and topographic map (scale about 1:1,000,000), and a similar map (scale about 1:140,000) of the area studied in detail, which shows also well locations and water levels in valley fill.

1949c. Ground water in northern Chile-A summary: Internat. Union Geodesy and Geophysics, Internat. Assoc. Sci. Hydrol. Oslo, 1948, v. 3, p. 248-55, 2 figs.

In the Norte Chico region of Northern Chile (lat $26^{\circ}$ to $33^{\circ} \mathrm{S}$.) the most important ground-water bodies occur in alluvial deposits of the major stream valleys. These bodies are recharged chiefly by infiltration from the floods resulting from winter rains (May to September) or the runoff of melt water from Andean snowfields during spring (September through November).

In the Norte Grande region (lat. $17^{\circ} 30^{\prime}$ to $26^{\circ} \mathrm{S}$.) extensive ground-water bodies occur in alluvial deposits that fill basins of interior drainage. Locally in or near these basins, aquifers occur in Miocene sandstones and conglomerates interclated with volcanic rocks. Recharge is from short, intense thunderstorms common during summer months (December to March).

1949d. (and Lemoine, Rémy C.). Les eaux souterraines dans la plaine des Gonaïves, Haïti: Rev. Soc. Haïtienne Histoire et Géographie, v. 20, no. 75, p. $8-26$, illus.

This is a French version of the paper of Taylor and Lemoine published in English in 1950.

1949e. (and Lemoine, R. C.). Les rivières et les sources de la plaine du Cul-de-sac; extrait du rapport sur les eaux souterraines de la plaine du Cul-de-sac. Haïti: Rev. Haïtienne Histoire et Géographie, v. 20, no. 75, p. 1-7.

Describes the rivers and springs of the Cul-de-sac plain, and includes stream-gaging data for 1922-40. 
1950. (and Lemoine, R. C.) Ground-water geology of the Gonaives plain, Haiti: Econ. Geology, v. 45, no. 2, p. 127-141, illus.

The Gonaïves plain, in northern Haiti, is potentially irrigable from groundwater sources although it is the driest lowland region in Haiti (rainfall averages 22.8 in per yr). Upper(?) Cretaceous volcanic rocks are largely impervious but locally give rise to small fracture springs. Eocene limestones give rise to important springs such as the Sources Madame Charles, which have a discharge of $1,600 \mathrm{gpm}$. Oligocene limestones and shales may be water bearing. The Quaternary alluvial fill will yield moderate to large supplies of ground water.

Includes a geologic map (scale about 1:200,000) which shows also water levels and well locations.

1952. The occurrence of ground water in rocks of western Rajasthan (India), in Proceedings of Symposium on the Rajputana Desert: India Natl. Inst. Sciences Bull. 1, p. 217-221.

Describes general features of ground-water occurrence and chemical quality of ground water in an area of some $75,000 \mathrm{sq} \mathrm{mi}$ in the Thar Desert.

1954. (and Oza, M. M.). Geology and ground water of the Dudhai area, eastern Kutch (India): India Geol. Survey Bull. 5, 75 p., 2 pls., 5 figs.

The chief aquifer is formed by sandstones of the upper Bhuj series of Early Cretaceous age. In 1952, the total annual draft for irrigation from upper Bhuj aquifers of the area was at the rate of 2,994 acre ft. Natural ground-water discharge by evapotranspiration and spring discharge was estimated at 16.3 acre-ft per day in April 1952. About $1 \mathrm{mgd}$ can be developed from aquifers between depths of $125 \mathrm{ft}$ to $350 \mathrm{ft}$ for the supply of the Kandla Port development of the Government of India.

Data include 289 well records, 115 chloride determinations, and a map (scale about 1:65,000) showing geology and water levels.

Taylor, G. H. See also Thomas, H. E., $46 \mathrm{c}$.

1949. (and Leggette, R. M.). Ground water in the Jordan Valley, Utah:

U. S. Geol. Survey Water-Supply Paper 1029, 357 p., 14 pls., 26 figs.

The Jordan Valley is a small part of the area that was covered by glacial Lake Bonneville. It is a rock-bottomed valley in which more than $2,000 \mathrm{ft}$ of lake and stream deposits consisting of clay, silt, sand, and gravel have been laid down. Shallow ground water occurs in small perched bodies in sand and gravel. At greater depths, sand and gravel interbedded with silt and clay form a large artesian reservoir. The most permeable sand and gravel are near the foot of the Wasatch Mountains in the area occupied by the Provo and Bonneville benches of Lake Bonneville. On these benches the water levels in wells stand considerably below the surface, but, along the Jordan River and west of Salt Lake City as far as the lake, many flowing wells have been drilled. Much discharge occurs through the several thousand flowing wells, many of which are allowed to flow continuously. The water is of generally good quality except in the northwestern part of the valley, where it is high in chloride. However, a tongue of low-chloride water extending toward Great Salt Lake, and the decline in ground-water head in that direction, indicate a flow of fresh water toward and possibly into the lake.

Data for the 400-sq-mi area include 1,750 well records, 41 well logs, periodic water-level measurements, streamflow records, and 76 chemical analyses. 
1951. Ground water in the Missouri River basin: Water Well Jour., v. 5, no. 4, July-August, p. 9-10, 22-29.

Reviews ground-water occurrence in the Missouri River basin and summarizes the ground-water work that has been done in the basin in the period 1945-50. Investigations indicate a much greater potential utilization of ground water, but also a need for ground-water regulation, more research, and more adequate data.

1952a. Water well records earthquake: U. S. Geol. Survey dupl. rept., 2 p., 1 fig.

Earthquake off coast of Kamchatka, Siberia, was recorded in a well at Lincoln, Nebraska.

1952b. The ground-water resources of Nebraska: U. S. Geol. Survey dupl. rept., 6 p., 5 figs.

Eighty percent of Nebraska's citizens are dependent on ground water; 450 of 454 public water supplies are from ground-water sources. Supplies are not depleted and large developments are yet possible. Much basic information is available but much more is needed.

1953a. Potential irrigation from ground-water sources in the Missouri River basin: U. S. Geol. Survey dupl. rept., 13 p., 5 figs.

Reviews growth and extent of irrigation in the Missouri Basin and cites areas where large ground-water supplies can be developed.

1953b. Ground water-The lifeblood of the High Plains: U. S. Geol. Survey dupl. rept., $13 \mathrm{p}$.

Reviews the development of the West and cites ground water as being one of the important factors.

Theis, Chas V. See also Hale, W. E., 42; Stuart, W. T., 48.

1942 (1953). (and Taylor, G. C., Jr., and Murray, C. R.). Thermal waters of the Hot Springs artesian basin, Sierra County, New Mexico: N. Mex. State Engineer 14th and 15th Bienn. Repts. 1938-42, p. 421492,1 pl., 7 figs.

Hot Springs (now Truth or Consequences), a health resort, is the site of several hot mineral-water springs. The water, which discharges at a temperature of about $114^{\circ} \mathrm{F}$, moves from the Magdalena limestone through the overlying alluvium to discharge to the Rio Grande. Artesian wells drilled into the limestone intercept the thermal water. The heat probably comes from igneous rocks at depth; and the water is derived from rainfall. The $100 \mathrm{gpm}$ developed represents only a fraction of the $1,600 \mathrm{gpm}$ discharged naturally.

Data include 2 measured stratigraphic sections, 12 well logs, 12 chemical analyses, and results for 2 aquifer tests of the Magdalena limestone. Maps show water levels, water temperatures, and areal geology (scale about 1:70,000).

1950. Ground water as a source supplemental to surface water: Western State Engineers Assoc. 23d Ann. Convention Proc., pp. 62-64.

Discusses the interdependence of ground-water flow and surface flow in stream valleys. Points out that the pumping of ground water near a stream must eventually decrease the flow of the stream, but the effects may not be shown for some time. The lag increases with the distance of the well from 
the stream. Although the effects may be masked, they can be predicted mathematically.

1951. (and Brown, R. H.). Use of slide rule in solving ground-water problems involving application of the nonequilibrium formula: U. S. Geol. Survey dupl. rept., $4 \mathrm{p}$.

Describes use of special slide-rule scales designed to read quickly drawdown values for many distances in a given aquifer at a given time.

1955. Geologic and hydrologic factors in ground disposal of waste, in Proceedings of Second Sanitary Engineering Conference, Baltimore, Maryland, April 15-16, 1954: U. S. Atomic Energy Comm. dupl. rept. (Wash-275), p. 261-283, 8 figs.

Some of the reasons especially favorable for disposal of waste into the ground are the generally low velocity of ground-water circulation and the capacity of most water-bearing materials for ion exchange. Problems regarding movement of wastes underground are raised by the high toxicity of the wastes, their heat-generating properties, their densities, and their chemical properties. Little information is available as yet for the solution of such problems, but waste cannot be put underground safely without a rather precise knowledge of the geology and hydrology. The term halfjourney is proposed (p. 268).

Thomas, Harold Edgar. See also Dennis, P. E., 46; Nelson, W. B., 53; Waite, H. A., 55.

1946a. Ground-water level fluctuations in Utah, 1936-45: Utah State

Engineer 25th Bienn. Rept., p. 65-89, 3 figs.

Gives data on fluctuations in 450 observation wells in 36 ground-water areas. Large natural losses in ground-water basins range upward from 25 percent of estimated average annual recharge.

1946b. Ground water in Tooele Valley, Tooele County, Utah: Utah State Engineer Tech. Pub. 4, in Utah State Engineer 25th Bienn. Rept., p. 97-238, 6 pls., 21 figs.

Ground water in Tooele Valley (in the Basin and Range province) occurs principally in Pleistocene sediments filling the basin.

The report contains 22 comprehensive and 102 partial chemical analyses, a detailed interpretation of water-level fluctuations, and a geologic map (scale 1:62,500).

1946c. (and Taylor, G. H.). Geology and ground-water resources of Cedar City and Parowan Valleys, Iron County, Utah: U. S. Geol.

Survey Water-Supply Paper 993, 210 p., 27 pls., 17 figs. [1947].

Ground water in both valleys (in the Basin and Range province) occurs in unconsolidated sediments filling the basins.

Data include 745 well records, 15 well logs, 6 measured sections, fossil lists, well discharges, and 110 partial chemical analyses. Maps show groundwater areas, water levels, water-level changes, depth to water, and areal geology (scale 1:63,360).

1948. (and Nelson, W. B.). Ground water in the East Shore area, Utah; part 1, Bountiful district, Davis County: Utah State Engineer Tech. Pub. 5, in Utah State Engineer 26th Bienn. Rept., p. 52-206, 2 pls., 20 figs.

Basic dàta include 9 well logs, 2 measured sections, a fossil list, and 97 
chemical analyses. Interpretive studies include a water-level map, 5 geologic cross sections, a geologic map (scale about 1:30,000), ground-water temperatures, and a review of 2 water-spreading experiments.

1949a. Sanitary quality of ground-water supplies: Sanitarian, v. 11, no. 5, p. 147-151.

Because bacteria find the optimum living conditions at the water table, wells furnishing domestic supplies should be tightly cased from the surface down to several feet below the water table. Cites bacterial contamination in deep water wells at Houston, Texas, and includes selected references on bacterial pollution of ground water.

1949b. Artificial recharge of ground water by the city of Bountiful, Utah: Am. Geophys. Union Trans., v. 30, no. 4, p. 539-542, 2 figs.

Attempts to recharge artesian aquifers west of Bountiful by diversion of surplus stream water into a spreading canal were unsuccessful because of the impermeability of mudflow debris along the western base of the Wasatch Range. Instead, the water seeping from the canal saturated the surficial shore deposits which crop out east of the city.

1951a. Fluctuations of ground-water levels: Internat. Union Geodesy and Geophysics, Internat. Asso. Sci. Hydrology, Brussels, 1951, v. 2, p. 143-147.

Description of types of water-level fluctuations observed in wells and discussion as to what constitutes a sufficiency of these basic data.

1951b. Ground-water problems of closed basins: Nev. State Engineer 6th Water Conf. Proc., p. 59-64.

A brief discussion of problems in development and control of groundwater resources in the Great Basin.

1952a. Ground-water regions of the United States: their storage facilities: U. S. Cong., House Comm. Interior and Insular Affairs, Phys. and Econ. Found. Nat. Res., v. 3, 78 p., 48 figs.

Ten major ground-water regions are described: (1) western mountain ranges, (2) arid basins, (3) Columbia lava plateau, (4) Colorado Plateau, (5) Great Plains, (6) unglaciated central region, (7) glaciated central region, (8) unglaciated Appalachian region, (9) glaciated Appalachian region, and (10) Atlantic and Gulf Coastal Plains. Effective use of underground storage facilities must take into consideration the uses of water, the limitations of aquifers, and the manipulation of storage, including artificial recharge.

1952b. A hydrogeologic problem in the proposed Echo Park reservoir: U. S. Geol. Survey dupl. rept., 7 p., 2 figs.

Measurable losses from Green River above Jensen, Utah, during high stage are attributed chiefly to replacement of water discharge in preceding year by evapotranspiration in Browns Park, Island Park, and Lily Park. It is possible, but not probable, that some of these losses result from seepage into the cavernous Madison limestone of Mississippian age.

1952c. Hydrologic reconnaissance of the Green River in Utah and Colorado: U. S. Geol. Survey Circ. 129, 32 p., 1 pl., 4 figs.

This report outlines the geology and ground-water hydrology of the rocks bordering the Green River along its 437-mi channel in Utah and Colorado. It also presents data on the quantity and quality of the water during a 21-day 
period in 1948 when the river was at minimum stage. The average flow of the river as it entered Utah from Wyoming was $515 \mathrm{cfs}$; the inflow to the river in Utah and Colorado totaled $560 \mathrm{cfs}$ from tributaries and $330 \mathrm{cfs}$ from ground water. About 75 per cent of the ground water was contributed to the river within the Uinta Basin. Evapotranspiration losses averaged 430 cfs. These estimates are based upon information collected during a boat reconnaissance in 1948.

1952d. (and Hansen, G. H., and Lofgren, B. E.). Deep water wells in Utah County, Utah: U. S. Geol Survey dupl. rept., 4 p.

Wells drilled near Provo show that there are aquifers far below those tapped by the 3,000 other wells in northern Utah Valley.

1952e. (and Nelson, W. B., Lofgren, B. E., and Butler, R. G.). Status of development of selected ground-water basins in Utah: Utah State Engineer Tech. Pub. 7, 96 p., 26 figs.; Utah State Engineer 28th

Bienn. Rept., July 1, 1950, to June 30, 1952, p. 111-206, 26 figs.

This publication consists essentially of abstracts of more detailed reports which have been published, plus evaluation of data collected subsequently. The basins include Cedar City Valley, Parowan Valley, the Beryl-Enterprise and Milford districts of Escalante Valley, Pavant Valley, Sevier Desert, Utah Valley, Jordan Valley, East Shore area, and Ogden Valley.

1952f. (and Wilson, M. T.). Determination of total evapotranspiration in Ashley Valley, Utah, by the inflow-outflow method: U. S. Geol. Survey dupl. rept., 15 p., 5 figs.

Evapotranspiration is determined from measurements of surface inflow and outflow, and ground-water inflow and outflow, for periods beginning: and ending with approximately equal ground-water storage.

1953a. Reconnaissance studies of the Green River: Sci. Monthly, v. 77, no. 2, p. 95-102, 6 figs.

Summarizes streamflow gains from tributaries, ground-water inflow, and losses from evapotranspiration. The paper is based on a 2-week boat trip through the Green River from the Wyoming State line to the confluence with the Colorado River. Data collected indicate that, at low flow in 1948, the water in the Green River at the Wyoming State line would have been reduced about 85 percent by evapotranspiration losses in Utah and Colorado if there had been no inflow of ground water.

1953b. Methods and results of ground-water investigations in the arid parts of the United States: Desert Research, Research Council Israel, Special Pub. 2, p. 605-610.

Reviews briefly the various types of ground-water investigations: exploratory, systematic areal, detailed quantitative, and research.

1953c. Water resources, in Hunt, C. B., Varnes, H. D., and Thomas, H. E., Lake Bonneville; Geology of northern Utah Valley, Utah: U. S. Geol. Survey Prof. Paper, 257-A, p. 60-92, pl. 3, figs. 16-22.

Because arable land is far more abundant than water supplies, water is the limiting factor in the arid west. Utah Valley, however, is fortunately situated where it can harvest the water crop of tributary drainage basins that include high mountains having abundant precipitation.

The section on water resources includes a history of water utilization and well development, data on water-supply fluctuations, and a discussion of 
maximum potential development of water resources in the valley. Illustrations include a water-level map.

1953d. Map showing water supply of Hollidaysburg quadrangle, Pennsylvania, in Eckel, E. B., and others, Interpreting geologic maps for engineering purposes: U. S. Geol. Survey special map, 6 maps.

Interpretations for the Hollidaysburg quadrangle are used as an example of the hydrologic information that can be obtained from geologic and topographic maps.

1954 (1955). Preliminary studies of the southwestern drought: Nev. State Engineer 8th Water Conf. Proc., p. 109-118.

The area covered by the southwestern drought of 1942-53 includes nearly all of Arizona and New Mexico, more than half of California and of Texas, substantial parts of Nevada, Utah, and Colorado, and a bit of Oklahoma. This drought is compared with others since 1870. Precipitation trends are analyzed in relation to the effects of drought upon supplies of surface and ground water. Drought is defined.

1955a. Water rights in areas of ground-water mining: U. S. Geol. Survey Circ. 347, 16 p., 1 fig.

Of the several major phases involved in current attempts by several States to devise equitable yet hydrologically and legally feasible means of controlling the withdrawal and use of ground water, one of the most significant is the problem of ground-water mining-the withdrawal of water from an aquifer at a rate greatly in excess of replenishment and the gradual exhaustion of stored water. Both major doctrines of water law that are in common useriparian, or landownership, and appropriative-are based on the assumption that a perennial water supply is available. The States, principally in the West, where large-scale ground-water mining is taking place either are undecided as to a method of administering ground-water rights in such areas or are attempting to adapt the existing laws. The result in some "appropriation" States is likely to be a combination of the landownership and appropriative systems that takes into account the exhaustibility of the resource.

1955b. Underground sources of our water, in Water: U. S. Dept. Agriculture Yearbook 1955, p. 62-78, 3 figs.

A general statement concerning occurrence and movement of ground water and the problems of development. Included are maps of the United States showing ground-water areas, significant cones of depression developed by pumping from wells, and major ground-water reservoirs in a state of perennial overdraft. These maps are reproduced from "The conservation of ground water," by Harold E. Thomas, published by McGraw-Hill in 1951.

1955c. Occurrence and utilization of ground water in the United States: Internat. Union Geodesy and Geophysics, Internat. Assoc. Sci. Hydrology, Rome, 1954, v. 2, p. 324-329, 1 fig.

A brief summary of ground-water utilization in the United States and the regions and types of aquifers that are most productive. Aquifers capable of large yield occur chiefly in regions of, and because of, major diastrophic changes.

Thomasson, Horace G. See Garrett, A. A., 49; Upson, J. E., 51 c.

Thompson, David G. See Klaer, F. H., Jr., 48c. 
Tibbitts, Gordon C., Jr. See Sinnott, Allen, 54, 55.

Todd, David K. See Klaer, F. H., Jr., 48a.

Torrey, Alfred E. See also Moulder, E. A., 53.

1951. (and Swenson, F. A.). Ground-water resources of the lower Yellowstone River valley between Miles City and Glendive, Montana, with a section on chemical quality of the water by H. A. Swenson: U. S. Geol. Survey Circ. 93, 72 p., 1 pl., 12 figs.

The lower Yellowstone River between Miles City and Glendive, Montana, is bordered by stream terraces. Extensive areas on the lower terraces are irrigated at the present time, and additional areas are proposed for irrigation. The terrace deposits and the alluvium are sources of shallow groundwater supplies. The Fort Union and Hell Creek formations and the Fox Hills sandstone underlie the area and are sources of deeper supplies; in topographically favorable locations, wells ranging in depth from 200 to $600 \mathrm{ft}$ obtain flowing water from sandstone beds in the bedrock formations. Several areas in the valley have become waterlogged. In general, ground water near the land surface is relatively high in calcium and magnesium, but with increasing depth these are exchanged for sodium, the result being a natural softening. There seems to be no tendency for the water to acquire more dissolved material with increasing depth, the amount of dissolved solids being determined relatively near the surface. Most of the ground water is satisfactory for drinking but is unsuitable for irrigation because of a high percentage of sodium or high mineral content.

Data for the 600-sq-mi area include 268 well records, 25 chemical analyses, periodic water-level measurements, and a geologic map (scale 1:63,360).

Toulmin, Lyman D., Jr.

1951. (and LaMoreaux, P. E., and Lanphere, C. R.). Geology and ground-water resources of Choctaw County, Alabama: Ala. Geol. Survey Special Rept. 21 and County Rept. 2, 197 p., 11 pls., 23 figs.

Ground water in Choctaw County is obtained from water-bearing sand beds in the gentle southward- and southwestward-dipping formations of the Coastal Plain. Drilled wells in the area generally range in depth from $\mathbf{1 5}$ to $715 \mathrm{ft}$ and yield as much as $300 \mathrm{gpm}$. Supplies of good-quality ground water adequate for most private, industrial, and municipal purposes are available except in two townships in the northeastern corner of the county. Much additional water could be obtained from full development of the aquifers in the county.

Data for the 918-sq-mi county include 165 well records, 40 chemical analyses, fossil lists, measured geologic sections, particle-size analyses, and an areal geologic map (scale about 1:125,000).

1953 (1955). (and LaMoreaux, P. E.). Profile showing geology along State Highway 17, Choctaw County, Alabama: Ala. Geol. Survey Special Map. 8.

Aquifers include the sand of the Coal Bluff marl member of the Naheola formation, basal and middle part of the Nanafalia formation, basal part of Tuscahoma sand, Bashi marl member and upper sand of the Hatchetigbee formation, Meridian sand member of the Tallahatta formation, sands of the Lisbon formation, Gosport sand, Cocoa sand member of the Yazoo clay, and alluvial sands and gravels. 


\section{Trainer, Frank W.}

1953. Preliminary report on the geology and ground-water resources of the Matanuska Valley agricultural area, Alaska: U. S. Geol. Survey Circ. 268, 43 p., 1 pl., 6 figs.

This area is part of a glaciated valley in south-central Alaska. Most of the valley is underlain by unconsolidated deposits, chiefly till and outwash gravel and sand. The land surface is underlain by loess which forms the parent material of most of the soil. Gravel is the most important waterbearing material; the till is relatively impermeable, and where it overlies gravel and sand, artesian conditions may prevail. Wells finished in gravel and sand provide domestic or farm water supplies. Palmer, a community of about 800 , uses a surface-water supply but use of wells in the future is contemplated.

Data for the 350-sq-mi area include 333 well records, 3 well logs, hydrographs, 19 chemical analyses, particle-size analyses, a measured section, and a surficial geologic map (scale 1:62,500).

\section{Trauger, F. D.}

1950. Basic ground-water data in Lake County, Oregon: U. S. Geol. Survey dupl. rept., 287 p., 26 pls.

Data for the 8,270-sq-mi area include 825 well and 66 spring records, 95 well $\operatorname{logs}, 31$ chemical analyses, and a geologic map (scale about 1:127,000).

Troxell, Harold C. See also Stafford, H. M., 53; Briggs, R. C., 55.

1949. (and Stafford, H. M.). Natural water losses in mountain drainage areas of southern California: Am. Geophys. Union Trans., v. 30, no. 5, p. 752-758, 3 figs.

In small mountain drainage areas of southern California, natural water losses (evapotranspiration) vary with basin altitude and with absorptive and retentive characteristics of the soil and rocks. The average annual water loss varies directly with annual precipitation up to a point beyond which the loss is about constant.

1951. (and Poland, J. F., and others). Some aspects of the water supply in the South Coastal Basin, California: U. S. Geol. Survey Circ. 105, 10 p., 5 figs.

Water-supply factors considered are precipitation, runoff, waste to ocean, ground-water storage, and ground-water recharge. Estimates are made of the total recoverable water supply (including that used by vegetation) and of the annual water supply available from wells and streams. The former is estimated at 1,600,000 acre-ft per $\mathrm{yr}$ and the latter at 700,000 acre $\mathrm{ft}$.

1953. The influence of ground-water storage on the runoff in the San Bernardino and eastern San Gabriel Mountains of southern California: Am. Geophys. Union Trans., v. 34, no. 4, p. 552-562, 5 figs.

The steep and rugged mountains of southern California contain considerable ground-water storage. A large portion of the runoff represents seepage from this storage. The variations in runoff distribution depend on the geology, physiography, and soil cover of these mountain areas.

1954. (and others). Hydrology of the San Bernardino and eastern San Gabriel Mountains, California: U. S. Geol. Survey Hydrol. Inv. Atlas HA 1,13 pls.

This atlas shows by simple graphic methods some of the important rela- 
tionships among hydrologic factors and the effect of these factors upon the water resources of the San Bernardino and eastern San Gabriel Mountains in southern California, an area totaling about $1,200 \mathrm{sq} \mathrm{mi}$. The atlas analyzes, mostly by means of illustrations, the complicated circulation of water in the area that is responsible for much of the moisture that reaches crops of the agriculturally rich upper Santa Ana Valley. Climatic, physiographic, and geologic features and their effects on precipitation and runoff are shown. Maps showing the topography, river systems, absorptive quality of mantle rock, areal distribution of precipitation, and areal distribution of water surplus or deficiency are included. Relations between precipitation, streamflow, potential natural water loss, recoverable water, and recharge to ground water are illustrated by graphs. The atlas describes also the utilization of water in the area.

Turcan, Alcee N., Jr. See also Jones, P. H., 48a, 54b; Meyer, R. R., 55b.

1950. (and Whaley, L. J.). Report on ground-water conditions in southwestern Louisiana for the year 1949, in Summary of progress of the water-resources investigation in southwest Louisiana: La. Dept. Pub. Works dupl. rept., 7 p., 3 pls.

Discusses ground-water use, water-level changes, and water quality for rice irrigation. Data include 20 chemical analyses, 2 water-level maps, and a well hydrograph.

1952. Industrial use of ground water in Louisiana: La. State Univ. Eng. Expt. Sta. Bull. 31, p. 1-16, 3 figs.

In 1949 the average industrial pumpage of ground water in Louisiana was about $334 \mathrm{mgd}$. Additional ground-water supplies ranging from 10 to 100 mgd can be developed from artesian aquifers that underlie most of the southern and north-central parts of the State. Local supply problems are due mostly to improper well spacing or overpumping of individual wells. Disposal of oil-field brines constitutes the only large-scale use of aquifers in Louisiana for industrial-waste disposal.

Data include amounts of ground water used by principal industries, 32 chemical analyses, and amount of waste disposed of through wells in each of six areas in Louisiana.

1953. Utilization of water resources of Louisiana for municipal supply: La State Univ. Eng. Expt. Sta. Bull. 36, p. 8-26, 2 figs.

In 1949 pumpage for public water supplies was $185 \mathrm{mgd}$. Of this total, $54 \mathrm{mgd}$ was ground water used to supply 180 municipalities. Most supply difficulties are due to improper well spacing or poor well development.

1955. Utilization of ground water in Louisiana for industrial purposes:

La. State Univ. Eng. Expt. Sta. Bull. 51, p. 20-39, 6 figs.

In 1954, ground-water pumpage for all purposes was $910 \mathrm{mgd}$, of which $340 \mathrm{mgd}$ was used by industries. Problems of water shortage resulting from declining water levels have occurred at Baton Rouge, Ville Platte, Lake Charles, New Orleans, and West Monroe: corrosion and contamination by salt water threaten the water in the " $700-\mathrm{ft}$ " sand at Lake Charles; lack of a potable supply is a problem at Chase.

Turner, Samuel F. See also Hazen, G. E., 46.

1946. (and others). Ground-water resources and problems of the Safford basin, Arizona: U. S. Geol. Survey dupl. rept., 28 p., 3 pls., 4 figs. 
Chief aquifers are beds of sand and gravel along the sides of the basin and their extensions into the silt and clay of the lake beds. Ground water is derived from infiltration of rainfall and seepage from streams crossing the gravel zone.

Data for the 1,000-sq-mi area include 34 well records, 13 well logs, and 29 chemical analyses. Maps show distribution of dissolved solids in alluvial fill and generalized geology (scale about 1:230,000).

1947. (and others). Further investigations of the ground-water resources of the Santa Cruz basin, Arizona: U. S. Geol. Survey dupl. rept., 45 p., 4 figs.

Estimated perennial yield of each of the areas in the Santa Cruz basin is: Upper Santa Cruz area, 80,000 acre-ft; Eloy area, 25,000 acre-ft; Maricopa area, 10,000 acre-ft; and Casa Grande-Florence area, 100,000 acre-ft.

Data include 123 well records, 44 well $\operatorname{logs}$, and 68 chemical analyses. For a more recent report, see Halpenny 52.

1952. (and Skibitzke, H. E.). Use of water by phreatophytes in 2,000foot channel between Granite Reef and Gillespie dams, Maricopa County, Arizona: Am. Geophys. Union Trans., v. 33, no. 1, p. 66-72, 6 figs.

The kind and amount of phreatophyte growth were mapped from aerial photos. Transpiration was computed using the results of the mapping combined with water-use factors. Estimates were made of the amount of water used by phreatophytes and the amount that is potentially recoverable through their removal.

\section{Twichell, Twigg}

1954. Interrelation of surface and ground water in Texas: Tex. Univ. Law School Water Law Conf. Proc., p. 30-37.

The ground-water portion of the average annual flow of Texas streams ranges from 8 percent for the Neches River at Rockland to about 88 percent for the Devils River near Del Rio.

Tychsen, Paul C.

1950. Geology and ground-watex hydrology of the Heart River irrigation project and the Dickinson area, North Dakota, with a section on the mineral quality of waters of the Heart River project, by H. A. Swenson: U. S. Geol. Survey Circ. 34, 59 p., 1 pl., 7 figs.

The Heart River irrigation project is in the lower reaches of the Heart River valley in Morton and Grant Counties. The chief aquifers are the Cannonball and Ludlow formations, the Fort Union formation, and alluvium. Present withdrawals do not seriously deplete the supply. At Dickinson, ground-water levels have declined but the impounding of the Heart River is expected to insure a more adequate water supply for the town.

Data for the 400-sq-mi area include 132 well records, 1 well log, waterlevel measurements, 42 chemical analyses, 3 measured sections, 2 cross sections, and a geologic map (scale about 1:200,000).

1955. (and Vorhis, R. C.). Reconnaissance of geology and ground water in the lower Grand River valley, South Dakota, with a section on the chemical quality of the ground water by E. R. Jochens: U. S. Geol. Survey Water-Supply Paper 1298, 33 p., 2 pls., 3 figs.

The area described is the flood plain of the Grand River and the bordering 
benchlands in Perkins and Corson Counties, from near Shadehill to the confluence of the Grand and Missouri Rivers near Mobridge. Valley alluvium is the major aquifer. Small to moderate ground-water supplies can be obtained also from the Fox Hills sandstone, Hell Creek formation, and Fort Union formation, where they are saturated.

Data for the 500-sq-mi area include 131 well records, 13 chemical analyses, a fossil list, a geologic cross section, and a geologic map (scale 1:125,000).

Unklesbay, A. G.

1946. (and Cooper, H. H., Jr.). Artificial recharge of artesian limestone at Orlando, Florida: Econ. Geology, v. 41, no. 4, pt. 1, p. 293-307, 9 figs.

Surface drainage is inadequate at Orlando, and wells have been drilled into Jocene limestones to drain streets, control lake levels, and dispose of sewage and other waste liquids. Generally artesian water levels are far enough below the land surface to permit gravity drainage. As the limestones are avernous, they have large capacities for receiving water and seldom become logged.

Data include a cross section and 6 water-level maps.

"Jpson, Joseph E. See also LaRocque, G. A., Jr., 50.

1951a. Geology and ground-water resources of the south-coast basins of Santa Barbara County, California, with a section on surface-water resources by H. G. Thomasson, Jr.: U. S. Geol. Survey Water-Supply Paper 1108, 144 p., 9 pls., 11 figs.

Describes the geology and the surface- and ground-water resources of the Tarpinteria and Goleta basins; collectively, the south-coast basins of Santa 3arbara County, California, are described. Gives data on and estimates of "'mnoff from the Santa Ynez Mountains and recharge and discharge of the 1 wo ground-water basins during the period 1935-44. The quality of water nd the possibility of sea-water encroachment are discussed. The perennial ield of the Carpinteria basin is estimated to be about 1,700 acre-ft and that $r$ f the Goleta basin, about 3,100 acre-ft.

Data for the 75-sq-mi area include 62 well $\operatorname{logs}, 2$ water-level contour maps, F geologic cross sections, 28 comprehensive and 83 partial chemical analyses, ind 2 geologic maps (scale 1:31,680).

1951b. (and Worts, G. F., Jr.). Ground water in the Cuyama Valley, California: U. S. Geol. Survey Water-Supply Paper 1110-B, p. 21-81, pls. 1-5, figs. 9-10.

The geology and ground-water conditions are described for the Cuyama "alley in northern Santa Barbara County and the quality of water is dis"'issed. The perennial yield is estimated to be on the order of 9,000 to 13,000 f cre-ft and the estimated net pumping draft in 1946 was about 11,200 rore-ft.

Data for the 200-sq-mi area include 43 well logs, 29 comprehensive and 64 "artial chemical analyses, and a reconnaissance geologic and water-level rap (scale about 1:60,000).

1951c. (and Thomasson, H. G., Jr.). Geology and water resources of the Santa Ynez River basin, Santa Barbara County, California: U. S.

Geol. Survey Water-Supply Paper 1107, 193 p., 7 pls., 23 figs.

Describes the geology and the surface- and ground-water resources of the anta Ynez River valley in southwestern Santa Barbara County. Estimates 
of recharge and discharge are given for the period 1935-44. The perennial yield is estimated for two subareas: Buellton subarea, between 2,400 and 7,600 acre-ft; and Lompoc subarea, at least 10,000 acre-ft.

Data for the 200-sq-mi area include 124 well $\operatorname{logs}$, 2 water-level maps, 10 geologic cross sections, and two geologic maps (scale 1:48,000).

1955a. Ground-water sources on Long Island: Am. Water Works Assoc. Jour., v. 47 , no. 4 , p. 341-347.

Describes briefly the aquifers on Long Island that yield water to thousands of wells.

1955b. (and Kunkel, Fred). Ground water of the Lower Lake-Middletown area, Lake County, California: U. S. Geol. Survey Water-Supply Paper 1297, 83 p., 1 pl.

The geology and ground-water conditions in 15 valleys in southern Lake County are described. The development of ground water, yields of wells, character of the water-bearing deposits, storage capacity, and further development of ground-water supplies are discussed.

Data for the 200 -sq-mi area include 159 well records, 22 well logs, periodic water-level measurements in 19 wells, and 44 partial chemical analyses. A map (scale 1:125,000) shows extent of alluvium.

Van Tuyl, Donald W. See also Mangan, J. W., 52; Schaefer, E. J., 46b.

1947. (and Bernhagen, R. J.). Summary of ground-water conditions in Ohio: Ohio Water Res. Board Bull. 5, 32 p., 18 pls.

Records of water levels in observation wells for 1938-46 are presented graphically.

1948. (and Kaser, Paul). Ground-water levels in Ohio, 1947: Ohio Water Res. Board Bull. 16, 62 p., 30 figs.

Presents data on and interpretations of water-level fluctuation as observed in wells scattered through 47 of Ohio's 88 counties.

1950. Ground-water resources of the valley-fill deposits in the Pittsburgh area: Pa. Acad. Sci. Proc., v. 24, p. 155-160.

In Allegheny County the bedrock floor underlying the Ohio Valley has a downstream gradient of $0.8 \mathrm{ft}$ per $\mathrm{mi}$ and deposits of generally permeable alluvium range in thickness from 40 to $130 \mathrm{ft}$.

1951a. Ground water for air conditioning at Pittsburgh, Pennsylvania: Pa. Topog. and Geol. Survey Bull. W10, 34 p., 9 figs.

At Pittsburgh, in 1950, about $500 \mathrm{mg}$ was used for cooling. This was about 25 percent of the total pumpage for all uses. The future of the groundwater supply in the Triangle area is good, but little additional development seems to be feasible.

Illustrations include maps of water levels and bedrock surface in the Triangle area (scale about 1:12,000).

1951b. Air conditioning and ground water in Pittsburgh: Pa. Dept. Int. Affairs Monthly Bull., v. 19, no. 8, p. 10-16.

In the Triangle area of Pittsburgh, a proposed extension of the sheetpile cutoff wall along the river probably would reduce the recharge to the area and the yield of wells. Voluntary control of pumping, including reduction of waste, may prove to be the easiest and best method of conserving the ground-water supply. 
1951c. (and Klein, N. H.). Ground-water resources of Beaver County, Pennsylvania: Pa. Topog. and Geol. Survey Bull W9, 84 p., 1 pl., 11 figs.

The chief aquifer is glacial outwash sand and gravel in the Ohio River valley. Bedrock formations yield only a small percentage of the ground water used in the county. This use totals $23 \mathrm{mgd}$.

Data for the 441-sq-mi county include 111 well records, 50 well $\log$ s, 36 chemical analyses, and pumpage figures. Results are given for an aquifer test of the glacial outwash at Ambridge. A geologic map is based on published sources.

Vernon, Robert O. See Ferguson, G. E., 47.

Visher, F. N. See also Babcock, H. M., 51, 52b.

1952. Reconnaissance of the geology and ground-water resources of the Pass Creek Flats area, Carbon County, Wyoming, with a section on chemical quality of the water by W. H. Durum: U. S. Geol. Survey Circ. 188, 19 p., 1 pl., 8 figs.

A reconnaissance of the geology and ground-water resources of the Pass Creek Flats area in central Carbon County was made to determine the possibilities of developing ground-water supplies for irrigation. Aquifers in the area are the North Park formation and alluvium. The North Park formation, which is locally $1,700 \mathrm{ft}$ thick, is too fine grained, and the alluvium, which is coarser, is too thin to permit the development of large supplies. Several large springs issue from fault zones within the area, and it may be nossible to develop water supplies from wells drilled into these zones.

Data for the 170-sq-mi area include 25 well and spring records, physical properties of samples from the North Park formation, 13 chemical analyses, and a geologic map (scale about 1:70,000).

1953. (and Babcock, H. M.). Ground-water conditions in the Soil and Moisture Conservation demonstration area near Torrington, Goshen County, Wyoming, with a section on chemical quality of the ground water by W. H. Durum and R. A. Krieger: U. S. Geol. Survey Circ. 238, 51 p., 3 pls., 15 figs.

The Soil and Moisture Conservation demonstration area, about 6 miles southeast of Torrington, Wyoming, is bounded on the upslope side by the Fort Laramie canal and on the downslope side by the Cherry Creek drain. Most of the area is underlain by slope wash, which is underlain by fractured viltstone (Brule formation) along the canal, by clay (Chadron formation) " $n$ the central part of the area, and by coarse sand and gravel along the Cherry Creek drain. In most of the area the depth to water in the slope wash is less than $10 \mathrm{ft}$. Seepage from the canal and laterals and from irrigation water applied to the land is the principal source of recharge. Tater moves away from the canal through fractures in the Brule formation and thence upward through the slope wash under hydrostatic head which is sufficient in some places to force the water to the surface. Transpiration $y$ plants and evaporation from the land surface are the principal means of rround-water discharge. In places the dissolved minerals in the ground water have become concentrated at the land surface. Lining the canal to nrevent further recharge from this source would aid in the reclamation of nart of the area affected by a high water table. No economically feasible 
method of draining the slope wash where it is underlain by the Chadron formation is proposed.

Data for the $4 \frac{1}{2} 2$-sq-mi area include 87 well records, 14 well logs, physical and hydrologic properties of slope wash, 19 water analyses, and 19 soil analyses. Illustrations include a water-level map, a bedrock-surface map, a fence diagram, and a geologic map (scale about 1:9,600). The method used for installing piezometers is described.

Vorhis, Robert C. See also Tychsen, P. C., 55.

1948. Geology and ground water of the Fort Lauderdale area, Florida: Fla. Geol. Survey Rept. Inv. 6, 32 p., 12 pls.

The chief aquifer is a sandy limestone containing permeable beds of shelly sand. The formation has a coefficient of transmissibility of $1.2 \mathrm{mgd} \mathrm{per} \mathrm{ft}$. Salt-water encroachment occurs locally near canals and may arise from residual salt-water bodies entrapped in Pleistocene time in formations below the more permeable aquifer.

Data include chloride determinations, results of an aquifer test of the limestone, and water-level maps of the Fort Lauderdale well-field area.

1953. Milwaukee "Hydroseismograms" and their interpretation: U. S. Geol. Survey dupl. rept., 5 p., 4 figs.

A water-level recorder at Milwaukee, Wisconsin, registered primary, secondary, and surface waves from large-magnitude earthquakes. The recorder used has a time scale of $12 \frac{1 / 2}{\mathrm{~mm}}$ per min.

1955. Interpretation of hydrologic data resulting from earthquakes: Geologische Rundschau, v. 43, no. 1, p. 47-52, 2 figs.

Streamflow changes lasting for months have been caused by earthquakes. Water levels in many wells fluctuate in response to earthquake waves, but the amplitudes observed seem unrelated, or related in a complex rather than a simple manner, to the magnitudes of the earthquakes causing them.

Waite, Herbert A.

1946. (and Reed, E. C., and Jones, D. S., Jr.). Ground water in the Republican River basin in Nebraska; pt. 4-Hitchcock, Hayes, Dundy, and Chase Counties: Nebr. Water Res. Survey Water-Supply Paper 1,32 p., 8 figs.

Data include 212 test-hole logs. A map of Hitcheock County shows the top of the Cretaceous bedrock and the saturated thickness of alluvium.

1947a. Geology and ground-water resources of Scott County, Kansas: Kans. Geol. Survey Bull. 66, 216 p., 16 pls., 16 figs.

The chief aquifer is the Ogallala formation. Alluvium along the principal stream valleys is locally important. Some wells in the southeastern quarter of the county obtain water from the Niobrara formation. The depth to water ranges from less than $25 \mathrm{ft}$ in the valleys to $160 \mathrm{ft}$ in upland areas. Ground water moves eastward through the county with an average gradient of $10 \mathrm{ft}$ per mi in the northern half and about $6 \mathrm{ft}$ per $\mathrm{mi}$ in the southern half.

Basic data for the 723-sq-mi county include 282 well records, 23 test-hole $\operatorname{logs}, 54$ well $\operatorname{logs}$, and 30 chemical analyses. Hydrologic maps show water levels, depth to water, and saturated thickness of the Tertiary and Quaternary deposits. Data are given for aquifer tests on Pleistocene and Pliocene sand and gravel. Geologic data include 2 measured sections, fossil lists, 3 
cross sections, a map of the pre-Tertiary surface, and an areal geologic map (scale about 1:125,000).

1947b. Ground-water levels in Platte Valley: Nebr. State Irrigation Assoc. 55th Ann. Conv. Proc., p. 73-80.

For a published version complete with illustrations, see Waite $48 \mathrm{~b}$.

1948a. Ground-water levels in the lower Platte River valley, Nebraska: Nebr. Univ. Conserv. and Survey Div. Water Survey Paper 3, 11 p., 7 figs.

Periodic measurements of depth to water in 260 observation wells give details on changes in water level throughout a 2,500-sq-mi area. Maps show water-level changes for the periods 1930-39, 1939-46, and 1930-46.

1948b. (and others). Progress report on the ground-water hydrology of the Republican and Frenchman River valleys in Nebraska, with a section on chemical quality of the ground water by H. A. Swenson: U. S. Geol. Survey Circ. 19, 83 p., 1 pl., 5 figs.

The valleys are partially filled with water-bearing sand and gravel deposited on a relatively uneven, eroded bedrock surface. These alluvial deposits range in thickness from essentially nothing to $75 \mathrm{ft}$. The present streams have cut through the deposits and have exposed the underlying bedrock at a number of places. Where sufficiently thick, the alluvial sand and gravel yield water freely to wells, and large ground-water supplies can be obtained. Irrigation wells range in yield from less than 500 to more than $1,000 \mathrm{gpm}$.

Data for the 450 -sq-mi area include 189 well records, periodic water-level measurements in 153 observation wells, hydrographs of 10 wells, some dating back to 1934, 34 chemical analyses, and a water-level map.

1949. (and others). Progress report on the geology and ground-water hydrology of the lower Platte River valley, Nebraska, with a section on chemical quality of the ground water by H. A. Swenson: U. S. Geol. Survey Circ. 20, 211 p., 9 pls., 14 figs.

The lower Platte River valley is taken to be the stretch between North Platte and Fremont, Nebraska. The amount of ground-water discharge in the summer months of 1947 was approximately double that of the previous summer. However, recharge during the fall of 1946 and the spring of 1947 was sufficiently great that the amount of water in storage in the valley at the end of the 2-year period was essentially the same as at the beginning.

Basic data for the 2,500-sq-mi area include 315 well records, 160 test-hole $\operatorname{logs}$, and 18 chemical analyses. Interpretive data include results of 8 aquifer tests on alluvium in the Platte Valley, computation of changes in ground-water storage, and maps of water-level change, water levels, and depth to water.

1954. (and others). Status of ground-water development in four irrigation districts in southwestern Utah, in Progress report on selected ground-water basins in Utah: Utah State Engineer Tech. Pub. 9, p. 5-93, 19 figs.

About 70 percent of all ground-water pumpage in Utah is in four districts in the southwestern part of the State: Milford, Beryl-Enterprise, Cedar City, and Parowan districts. In 1953 more than 118,000 acre-ft was pumped from 425 irrigation wells. Detailed pumpage and water-level data are given 
for each of the 4 districts and 14 hydrographs show water-level trends. Maps show water levels and water-level declines for both the Milford district and the Beryl-Enterprise district.

1955. (and Thomas, H. E.). Effect of current drought upon water supplies in Cedar City Valley, Utah: Am. Geophys. Union Trans., v. 36, no. 5, p. 805-812, 5 figs.

Water levels in Cedar City Valley, Utah, in 1954 were the lowest of record and 4 to $10 \mathrm{ft}$ lower than the minimums recorded during the drought of the 1930's. Ground-water withdrawal has exceeded replenishment in drought years, but it cannot yet be concluded that ground-water resources are overdeveloped in the sense that pumpage exceeds the long-term average replenishment to the reservoir.

Walker, Eugene H.

1953. Geology and ground-water resources of the Covington-Newport alluvial area, Kentucky: U. S. Geol. Survey Circ. 240, 26 p., 2 pls., 4 figs.

Water-bearing sand and gravel up to $75 \mathrm{ft}$ thick occur under the parts of Covington, Newport, and adjacent cities in Kentucky that lie in the Ohio River valley. These deposits, of glacial origin, fill the old bedrock channel, which is deeper than the present river bed and not everywhere directly under it. Ground-water pumpage averages about $3.7 \mathrm{mgd}$. It is believed that considerably more water could be developed, especially from wells located near the river to take advantage of infiltration from the river bed. The water is hard to very hard and contains enough iron to be objectionable for certain uses. Ground-water temperature varies a few degrees, especially near the river, but averages about $57^{\circ} \mathrm{F}$.

Data for the 10 -sq-mi area include 101 well records, 57 well $\operatorname{logs}, 19$ chemical analyses, and 4 cross sections.

Walker, William H. See Prée, H. L., Jr., 52, 53.

Walling, I. W. See also Hale, Harrison, 47.

1951. (and Schoff, S. L., and Dover, T. B.). Chemical character of surface water in Oklahoma, 1946-49: Okla. Div. Water Res. Bull. 5, 180 p.

Includes a section on water quality as related to the geology of the basins. Sources of natural contamination of waters are indicated and brief statements as to the general quality of water are made.

Walters, Kenneth L. See also Frye, J. C., 50.

1953. Geology and ground-water resources of Jackson County, Kansas: Kansas Geol. Survey Bull. 101, 90 p., 10 pls., 9 figs.

The chief aquifers are alluvium of stream valleys and glacial deposits in central and northern Jackson County. Both yield moderate quantities of water to wells.

Basic data for the 658-sq-mi county include 255 well records, 47 test-hole logs, water level data, and 24 chemical analyses. Interpretive data include a map of ground-water areas, 5 geologic cross sections, and a geologic map (scale about $1: 85,000$ ).

1954. Geology and ground-water resources of Marshall County, Kansas: Kans. Geol. Survey Bull. 106, 116 p., 7 pls., 7 figs.

The principal aquifers are alluvium, terrace deposits, and the Barneston 
limestone. Glacial deposits generally do not yield large quantities of water to individual wells, but, because of the large number of wells obtaining water from them, they probably should be considered among the principal aquifers. Ground-water use is about $2 \mathrm{mgd}$.

Basic data for the 911-sq-mi county include 248 well records, 80 test-hole logs, 9 measured sections, and 30 chemical analyses. Interpretative data include a map of ground-water regions, 5 geologic cross sections, and a geologic map (scale about 1:85,000).

Walton, William C. See also Foley, F. C., 53.

1953. The hydraulic properties of a dolomite aquifer underlying the village of Ada, Ohio: Ohio Div. Water Tech. Rept. 1, 31 p., 20 figs.

An aquifer test was made of the Tymochtee formation at Ada. The data collected were analyzed by the nonequilibrium and modified nonequilibrium formulas. Boundary effects were analyzed by means of the image-well theory and the law of times. Barometric efficiency was determined to be 40 percent, and the drawdown and recovery data were adjusted for water-level changes in atmospheric pressure. A map shows the bedrock surface.

1955. Ground-water hydraulics as an aid to geologic interpretation: Ohio Jour. Sci., v. 55, p. 13-20, 4 figs.

The coefficients of permeability, transmissibility, and storage are explained. The use of the nonequilibrium formula is described, and its application in studies of hydrogeologic boundaries by means of the method of images and the law of times.

\section{Warde, John M.}

1955. (and Richardson, R. M.). Waste disposal-Vital to atomic power development: Min. Eng., v. 7, no. 5, p. 458-461; reprinted in Jour. Metals, v. 7, no. 10, p. 1090-1092.

The problems of disposal of radioactive liquid wastes in the ground are basically geologic. Wastes injected into the ground may be made less dangerous by the natural sorption properties of clays and by chemical interactions.

Waring, Gerald A.

1947. (and Meinzer, O. E.). Bibliography and index of publications relating to ground water prepared by the Geological Survey and cooperating agencies: U. S. Geol. Survey Water-Supply Paper 992, $412 \mathrm{p}$.

This bibliography, an extension of Water-Supply Paper 427, lists 1,777 papers, including all those listed in Water-Supply Paper 427 and 1,168 additional papers issued through January 1946. It contains an abstract of each paper and an index of subjects and authors.

Warner, D. A. See also Rapp, J. R., 53a.

1946. Geology and ground-water resources of the Ranchester area, Wyoming: U. S. Geol. Survey dupl. rept., 11 p.

Five possible sources of ground water for the Ranchester municipal supply are known, but each has one or more disadvantages. The Tensleep sandstone (at about 7,500-10,000 ft), the Parkman sandstone member of the Mesa Verde formation (at about 3,000 ft), and the Lance formation (at about $1,000 \mathrm{ft}$ ) are all believed to be water bearing but are untested as to both quantity and quality. The Fort Union formation, which is at shallow depth, contains thin beds of sandstone that supply water to flowing wells, but the 
water contains an excessive amount of sodium sulfate. The alluvium in the Tongue River valley is only 10 to $30 \mathrm{ft}$ thick and yields very hard water. Test drilling is needed to ascertain the most desirable and most adequate source of supply.

Data include 1 well $\log$ and 3 chemical analyses.

Warren, M. A.

1955. (and Parker, G. G.). Quantitative studies in the Miami area, in Water resources of southeastern Florida: U. S. Geol. Survey WaterSupply Paper 1255, p. 197-290.

An additional $25 \mathrm{mgd}$ will be obtained for the Miami municipal supply by infiltration from canals to the cone of depression, by reduction of runoff to canals, and by evapotranspiration salvage due to lowering of water levels by pumping. The lowering of fresh-water head resulting from anticipated pumping will not divert enough natural discharge to cause salt-water encroachment.

Washburn, R. L.

1954. Preliminary investigation of ground water in the East Sound area, Orcas Island, San Juan County, Washington: U. S. Geol. Survey dupl. rept., 25 p., 2 pl.

Ground water occurs both above and below glacial till (hardpan).

Data for the 57-sq-mi area include 35 well records, 10 well logs, and results for aquifer tests of the pre-Vishon glacial outwash on Orcas Island.

Weaver, DeForrest E. See Broadhurst, W. L., $51 \mathrm{~b}$.

Webber, E. E. See Winslow, J. D., 53.

Weigle, J. M. See also Mundorff, M. J., 55.

1952. (and Mundorff, M. J.). Records of wells, water levels, and quality of ground water in the Spokane Valley, Spokane County, Washington:

U. S. Geol. Survey Wash. State Ground-Water Rept. 2, 102 p., 1 pl., 16 figs.

Glacially deposited gravels locally more than $500 \mathrm{ft}$ thick yield water abundantly. One well in the Spokane Valley is capable of yielding $45 \mathrm{mgd}$. Ground-water underflow is more than $650 \mathrm{mgd}$.

Data for the 175-sq-mi area include about 400 well records, 58 well logs, and 22 chemical analyses. A map shows water levels in Spokane Valley.

Weir, James E., Jr. See Conover, C. S., 55.

Weiss, Lawrence

1954. Foraminifera and origin of the Gardiners clay (Pleistocene), eastern

Long Island, N. Y.: U. S. Geol. Survey Prof. Paper 254-G, p. 143-163, pls. 32-33, figs. 14-17.

Twenty species of Foraminifera from the Gardiners clay in eastern Long Island, including one new species of Elphidium and one new subspecies of Nonion, are described in this paper. The lithology and micorfaunal content of the clay suggest deposition in shallow brackish water. Thus, it is unlikely that the Gardiners clay is a continuous or completely effective hydraulic seal between the outwash deposits and the underlying beds of Cretaceous age.

Wentworth, Chester $K$.

1955. (and Mason, A. C., and Davis, D. A.). Salt-water encroachment 
as induced by sea-level excavation on Angaur Island: Econ. Geology, v. 50, no. 7 , p. $699-680,4$ figs.

Angaur Island, $800 \mathrm{mi}$ southwest of Guam, has an area of $3.2 \mathrm{sq} \mathrm{mi}$ and consists of reef limestone. Excavations for phosphate extended below sea level and lakes formed in these excavations. Despite an annual rainfall of 110 in, salt water from tidal pulsations moved through fissured rock and contaminated fresh-water supplies and agricultural land. Ground-water investigations guided the selection of remedial measures, which included partitioning of lakes and bottom filling or back filling of compartments that failed to freshen because of fissures connecting them with the sea.

Wenzel, Leland K. See Byers, A. C., 46.

West, N. N. See Sundstrom, R. W., 49a.

West, Sam W. See also Nace, R. L., 55.

1952. (and Fader, S. W.). Records of wells and ground-water withdrawals in the Dry Creek area, Cassia and Twin Falls Counties, southern Idaho: U. S. Geol. Survey dupl. rept., 114 p., 1 pl., 2 figs.

Data for the 120 -sq-mi area include 227 well records, 105 well $\operatorname{logs}$, and well-discharge measurements.

1955. Ground-water and drainage problems in the Whitney terrace area, Boise, Idaho: U. S. Geol. Survey dupl. rept., 21 p., 1 pl., 8 figs.

The Whitney terrace has been changing from a farming to an urban area. Coincident with the change, the amount of farm irrigation has decreased but the amount of recharge from lawn sprinkling, yard irrigation, and liquid sewage effluent is much greater. Ground-water and drainage problems can be relieved by reducing the excessive recharge.

A map shows depth to water in the $5 \mathrm{sq}$ mi of the Whitney terrace area.

Whaley, Leslie J. See Turcan, A. N., Jr., 50.

Whetstone, G. W. See Sinnott, Allen, 50.

White, Donald E. See also Brannock, W. W., 48

1948. (and Brannock, W. W.). Sources of heat, water supply, and mineral content of Steamboat Springs, Nevada: Internat. Union Geodesy and Geophysics, Internat. Assoc. Sci. Hydrology, Oslo, 1948, v. 3, p. 168176, 3 figs.

Discusses the possible sources of heat for the springs, the temperature gradient, the composition of gases, the composition of the water, and sources of the mineral content.

1950. (and Brannock, W. W.). The sources of heat and water supply of thermal springs, with particular reference to Steamboat Springs,

Nevada: Am. Geophys. Union Trans., v. 31, no. 4, p. 566-574, 3 figs.

Thermal springs are classified as (1) nonvolcanic; (2) intermediate (excess heat from volcanism but water entirely meteoric); (3) volcanic (excess heat, much of the mineral content, and part of the water from a volcanic source). Criteria indicating the origin of a spring system are temperature relations, mineral content, composition of associated gases, response of discharges and water levels to meteoric influences, isotopic composition of the waters, and regional and local geologic evidence.

Steamboat Springs is concluded to be volcanic. The three-dimensional 
convection system is described. Mixing is caused by differences in density of water related largely to temperature; artesian conditions are not essential.

1953. (and Sandberg, C. H., and Brannock, W. W.). Geochemical and geophysical approaches to the problems of utilization of hot spring water and heat: 7th Pacific Sci. Cong., New Zealand, 1949, Proc., v. 2, Geology, p. 490-499.

Thermal springs are classified as nonvolcanic, intermediate, and volcanic; volcanic springs are subdivided into "normal" calcium bicarbonate water, acid sulfate water, and superheated steam. Chemical characteristics and problems of utilization of each type are described.

1955. Violent mud-volcano eruption of Lake City Hot Springs, northeastern California: Geol. Soc. America Bull., v. 66, no. 9, p. 11091130, 4 pls., 3 figs.

During the night of March 1 and 2, 1951, an inconspicuous group of hot springs and small mud volcanoes burst into spectacular eruption. A cloud of steam, gases, and mud particles rose several thousand feet in the air. The eruption is estimated to have involved 300,000 tons of mud. The hotspring system is in thick, fine-grained clastic sediments immediately east of the Surprise Valley fault bounding the Warner Range. The sediments of the spring area contain near-neutral hot saline water. Eruptions in deep fine-grained basin sediments are attributed to unstable or metastable temperature-depth relations existing in many high-energy thermal systems. Vapor pressure at depth may equal or exceed hydrostatic pressure.

White, George W. See Schaefer, E. J., 46b; Winslow, J. D., 53.

White, Walter F., Jr. See Graham, J. B., 51b; Mangan, J. W., 52.

White, Walter N. See also Follett, C. R., 49.

1946. The occurrence and development of ground water in the 17 western States: Assoc. Western State Engineers 19th Ann. Convention Proc., p. 116-125.

A few facts on ground-water use for irrigation are given for each of the 17 western States. Several ground-water problems in the West needing investigation are mentioned.

Williams, Charles C.

1946a. (and Bayne, C. K.). Ground-water conditions in Elm Creek valley, Barber County, Kansas, with special reference to contamination of ground water by oil-field brine: Kans. Geol. Survey Bull. 64, pt. 3, p. 77-124, 2 pls., 9 figs.

Along parts of the east side of Elm Creek valley, ground-water quality is affected by intrusion of oil-field brine and further encroachment is likely with heavy pumping.

Data for the 23-sq-mi area include 25 test-hole $\operatorname{logs}, 11$ well $\operatorname{logs}$, a waterlevel map, 51 chemical analyses, 3 geologic cross sections, and a geologic map (scale about 1:36,000).

1946b. Ground-water conditions in Arkansas River valley in the vicinity of Hutchinson, Kansas: Kans. Geol. Survey Bull. 64, pt. 5, p. 145-216, 6 pls., 11 figs.

Large quantities of water are available from the McPherson formation in most parts of the area. The area along the border of the sand dunes at the 
edge of Arkansas River valley north and east of Hutchinson seems the most promising area for development of a municipal supply for Hutchinson.

Data for the 100-sq-mi area include 39 test-hole logs, 1 well $\log , 63$ chemical analyses, numerous particle-size analyses, laboratory determinations of permeability, a water-level map, a geologic cross section, and a geologic map (scale 1:40,000).

1947. (and Lohman, S. W.). Methods used in estimating the groundwater supply in the Wichita, Kansas, well-field area. Am. Geophys. Union Trans., v. 28, no. 1, p. 120-131, 10 figs.

The data available for study are summarized and several hydrologic factors are evaluated. The relation between ground-water levels and precipitation is shown, and recharge is estimated. The effect of pumping on water levels is shown graphically, and the quantity of water withdrawn from storage is estimated from several water-table contour maps. The data are analyzed and the quantity of water available for pumping is estimated.

1948a. Contamination of deep water wells in southeastern Kansas: Kans. Geol. Survey Bull. 76, pt. 2, p. 13-28, 3 figs.

Deep artesian aquifers of Ordovician age locally contaminated by mineralized water from the Cherokee shale of Pennsylvanian age. The contamination may occur either by downward movement along the outside of the casing or by corrosion and leakage into the casing. The pumping method was used to determine the location of leaks in wells at McCune, Cherokee, and Arma.

1948b. Ground water in the Newcastle area, Wyoming: U. S. Geol. Survey dupl. rept., $19 \mathrm{p}$.

Wells for municipal supply or other large-scale uses should be drilled at least to the lower part of the Minnelusa sandstone and probably into the Pahasapa limestone. Analyses of water from the shallower rocks indicate that the water from these beds is chemically not suitable for municipal or industrial use.

Data include 2 well logs and 7 chemical analyses.

1949. (and Lohman, S. W.). Geology and ground-water resources of a part of south-central Kansas, with special reference to the Wichita municipal water supply: Kans. Geol. Survey Bull. 79, 455 p., 34 pls., 31 figs.

The chief aquifer is the McPherson formation (Equus beds of early reports). It had long been used as a source of public water supply by most of the cities in the area except Wichita. An adequate supply for Wichita can be obtained from wells in the McPherson formation about 20 miles northwest of the city. Recharge is calculated to be about 20 percent of the precipitation, or about 7 inches per year. Salt-water intrusion resulting from salt springs and disposal of oil-field brines are problems in parts of the area. The most favorable locations for developing additional large ground-water supplies are, in order of importance, the Arkansas Valley area, the McPherson channel area, and the Lindsborg area.

Basic data for the 2,340-sq-mi area include 727 well records, 161 testhole logs, 193 well logs, 2 measured geologic sections, particle-size analyses, laboratory determinations of permeability, 229 chemical analyses, and descriptions of 18 public water supplies. Results are given for aquifer tests of the McPherson formation and of alluvium in the Little Arkansas River valley at Wichita. Hydrologic illustrations include a water-level map, a 
depth-to-water map, and, for the Wichita well-field area, maps showing water levels and water-level changes. Illustrations include 7 geologic cross sections and an areal geologic map (scale about 1:125,000).

Willis, Gordon W.

1953. (and Knowles, D. B.). Ground-water resources of the Odell sandhills, Wilbarger County, Texas: Tex. Board Water Engineers Bull. 5301, 54 p., 12 figs.

The area contains favorable sites for the development of large groundwater supplies from the Seymour formation. About 225,000 acre-ft of water is now in storage. The natural discharge, which equals the natural recharge, is about 10,000 acre-ft per yr.

Data for the 75-sq-mi area include 110 well records, 70 test-hole logs, 24 comprehensive and 18 partial chemical analyses, and aquifer-test results for the Seymour formation. Illustrations include a fence diagram and maps showing topography of the Odell sandhills, contours on the Permian rocks beneath the sandhills, water levels, and saturated thickness of the sand.

1954. Ground-water resources of Tom Green County, Texas: Tex. Board Water Engineers Bull. 5411, 100 p., 2 pls., 12 figs.

Lowered water levels with corresponding decreases in yields indicate partial depletion of the principal aquifers, the Leona formation and the Bullwagon dolomite member of the Vale formation, and suggest that largescale ground-water irrigation is not feasible in Tom Green County.

Data for the 1,829-sq-mi county include 648 well and 11 spring records, 41 well $\operatorname{logs}$, and 235 chemical analyses. Illustrations include 3 cross sections and a geologic map (scale about 1:200,000).

Wilson, Harry D., Jr. See also Davis, G. H., 55.

1952. Preliminary report on the water-storage capacity of alluvial deposits along the Santa Ynez River above The Narrows, in Troxell,

H. C., and Wilson, H. D., Jr., Stream runoff and ground-water storage capacity, Santa Ynez River, Santa Barbara County, California: U. S. Geol. Survey dupl. rept., pt. 2, p. 64-157, 9 pls.

Storage capacity is estimated as 6,000 acre-ft in the Santa Ynez subarea, 37,000 acre-ft in the Buellton subarea, and 36,000 acre-ft in the Santa Rita subarea. The average specific yield ranges from 17.3 percent in the Buellton subarea to 24.0 percent in the Santa Ynez subarea. Four maps and 10 geologic cross sections show extent of alluvial deposits.

Wilson, M. T. See Thomas, H. E., $52 f$.

Wilson, W. W. See Prescott, G. C., 54.

Winslow, Allen G. See also Doyel, W. W., 54; Goines, W. H., 51; Lang, J. W., 50; Petitt, B. M., 55.

1950. Geology and ground-water resources of Walker County, Texas: Tex. Board Water Engineers Bull. 5003, 48 p., 2 pls., 4 figs.

The chief aquifers are the Oakville sandstone and Lagarto clay, undifferentiated, and the Catahoula sandstone. Electric logs of oil wells indicate that the Sparta sand contains fresh water in the northern part of the county.

Data for the 786-sq-mi county include 22 facsimiles of electric logs, pumpage figures, 188 well records, 39 well $\operatorname{logs}$, and 89 chemical analyses. A geologic map (scale about 1:130,000) is based on the 1937 geologic map of Texas. 
1952. (and Fluellen, T. R.). The Houston district, Texas; pumpage and decline of artesian pressure during 1950-51: Tex. Board Water Engineers Bull. 5201, 25 p., 17 figs.

Withdrawals of ground water in the Houston district averaged $254 \mathrm{mgd}$ in 1950. See also Doyel 1954.

1953. Bibliography of salt-water encroachment: U. S. Geol. Survey dupl. bibliography, $26 \mathrm{p}$.

General and foreign references are listed first, followed by references grouped by State. Papers concerning all types of salt-water encroachment are included, but neither annotations nor abstracts are given.

1954a. (and Doyel, W. W.). Salt water and its relation to fresh ground water in Harris County, Texas: Tex. Board Water Engineers Bull. 5409, 37 p., 15 figs.; U. S. Geol. Survey Water-Supply Paper 1360-F.

Salt-water encroachment is a major ground-water problem in the Houston area. Potential sources of salt-water contamination include lateral movement through the aquifer, upward movement of salt water from below, vertical movement around salt domes or along faults, downward seepage from surface sources, and contamination through leaking wells. Six possible types of flushing are shown diagrammatically. A graph shows the computed relation between hydraulic gradient and rate of advance of salt water in Harris County.

Other illustrations show heavily pumped areas, cross sections using facsimiles of electric logs, a map of the base of the fresh-water sands, and a water-level map.

1954b. (and Doyel, W. W.). Land-surface subsidence and its relation to the withdrawal of ground water in the Houston-Galveston region, Texas: Econ. Geology, v. 49, no. 4, p. 413-22, 4 figs.

The area of subsidence coincides with a region of large-scale ground-water withdrawals. The subsidence is attributed to compaction of clay as the artesian pressure is reduced. From a comparison of the volume of subsidence to the volume of water pumped, it seems that about one-sixth of the water pumped has been supplied from storage in the clays. In the northern part of the area the ratio of land-surface subsidence to decline in artesian pressure head is about 1 to 100 .

1954c. (and Doyel, W. W., and Gaum, C. H.). Ground-water resources of Jones County, Texas: Tex. Board Water Engineers Bull. 5418, 29 p., 1 pl., 2 figs.

Data for the 959-sq-mi county include 197 well records, 13 partial oil-test $\operatorname{logs}$, and 60 chemical analyses.

Winslow, J. D.

1953. (and White G. W., and Webber, E. E.). The water resources of Cuyahoga County, Ohio: Ohio Div. Water Bull. 26, 123 p., 60 pls.

Chief aquifers are the Sharon conglomerate and Berea sandstone. In the Mill Creek valley, glacial sand and gravel deposits appear capable of yielding still larger ground-water supplies.

Data for the 463-sq-mi county include more than 1,000 well records, about 600 graphic well $\operatorname{logs}, 20$ electrical-resistivity curves, and 36 chemical analyses. Maps show ground-water areas, bedrock geology, bedrock surface, and surficial geology (scale 1:62,500). 
Wisler, C. 0 .

1952. (and Stramel, G. J., and Laird, L. B.). Water resources of the Detroit area, Michigan: U. S. Geol. Survey Circ. 183, 36 p., 4 pls., 30 figs.

The potential water supply of the Detroit area is almost unlimited. In 1950 , the use of water from Lake St. Clair and the Detroit River was 2,896 mgd, or 2.5 percent of the available supply. The use from tributary streams was $10 \mathrm{mgd}$ or 1.2 percent of the available supply, and the use from groundwater sources was $43 \mathrm{mgd}$ or about 15 percent of the available supply. Ground-water supplies developed by inducing infiltration from the Huron River are described. Information is given on chemical quality of both ground water and surface water. Laws affecting the use of water in the area are described briefly, and a summary of the potential water resources of the region is given. Maps show thickness of glacial drift, surficial deposits and their water-bearing properties, and bedrock geology (scale about $1: 250,000)$.

Withington, Charles F. See Gordon, E. D., 53.

Wolcott, H. N. See also Bluhm, F. I., 49; McDonald, H. R., 47a, 47b.

1953. Memorandum on ground-water resources and geology of Rainbow Valley-Waterman Wash area, Maricopa County, Arizona: U. S. Geol. Survey dupl. rept., 13 p., 1 pl.

Because the alluvial ground-water reservoirs of Rainbow Valley and Waterman Wash are separated by a hard-rock barrier, no appreciable amount of ground water moves from one valley to the other.

Data include 73 well records, 5 well $\operatorname{logs}, 30$ chemical analyses, and a geologic map (scale about 1:210,000).

Worth, G. F., Jr. See also Davis, G. H., 55; Dennis, P. E., 49b; LaRocque, G. A., Jr., 50 ; Upson, J. E., $51 \mathrm{~b}$.

1951. Geology and ground-water resources of the Santa Maria Valley area, California, with a section on surface-water resources by $\mathrm{H}$. G. Thomasson, Jr.: U. S. Geol. Survey Water-Supply Paper 1000, 169 p., 6 pls., 9 figs.

Describes the geology and the surface and ground-water resources of the valleys of the Santa Maria, lower Cuyama, and lower Sisquoc Rivers, in northwestern Santa Barbara County. Estimates are given for the runoff from the region tributary to the area, the recharge to and discharge from the principal ground-water body for the period 1929-44, and the perennial yield of that body. Sea-water encroachment may result from pumping. The estimated perennial yield of 53,000 acre-ft was exceeded in 1944 by 12,000 acre-ft.

Data for the 260-sq-mi area include 100 well logs, water-level profiles, a water-level map, 9 geologic cross sections, 21 comprehensive and 65 partial chemical analyses, and a geologic map (scale 1:63,360).

Yost, C. B., Jr. See also F'eth, J. H., 53.

1953. Geophysical and geological reconnaissance to determine groundwater resources of Chiu Chuischu area, Papago Indian Reservation, Arizona: U. S. Geol. Survey dupl. rept., 19 p., 3 pls., 3 figs.

Data for the 30-sq-mi area include 46 well records, 15 well $\operatorname{logs}$, and 10 chemical analyses. Maps show water levels, depth to water, depth to bedrock, and areal geology (scale 1:63,360). 


\section{INDEX}

[The reader is referred to entries in the bibliography by (1) surname of the senior author, (2) the last two numerals of the year of publication, and (3) a letter designation if more than one report issued in the given year is cited under the author's name in the bibliography.]

Acid. See Contamination.

Addresses.

Ground water, Colorado River drainage basin: Sayre 50c

Ground-water investigations, Army watersupply installations: Fiedler $\mathbf{4 8}$

Ground-water investigations, United States: Sayre $48 b$

Ground-water problems of the West: Sayre $53 a$

Our water resources: Sayre 54

Water investigations, U. S. Geological Survey: Paulsen 48

Alabama.

Ground-water development: LaMoreaux $48 \mathrm{c}, 53 \mathrm{~b}$

Mine-water studies, Birmingham red iron ore district: Simpson, T. A., 55

Occurrence of ground water: LaMoreaux $48 \mathrm{a}$

Pond drainage by wells: LaMoreaux $49 a$

Areal reports.

Birmingham area, Jefferson County: Robinson, W. H. 53

Choctaw County: Toulmin 51, 53

Huntsville area, Madison County: LaMoreaux 50c; Sanford 55

Mobile area, Mobile County: Peterson 47

Southeastern Alabama: LaMoreaux 49b

Tennessee Valley area: LaMoreaux $49 \mathrm{a}$

Geologic maps.

Choctaw County: Toulmin 51, 53

Hydrologic maps.

Alabama: LaMoreaux 53b

Huntsville area: Sanford 55

Public water supplies.

Description and chemical quality: Lohr $54 a$

Ground-water use: LaMoreaux $48 c, 49 b$

Quality of water.

Fluoride, Alabama: LaMoreaux 50a

Coastal Plain: LaMoreaux $\mathbf{4 7}$

Tertiary area: LaMoreaux $48 \mathrm{~b}$

Nitrate, Coastal Plain waters: LaMoreaux $50 \mathrm{~b}$

Public supplies: Lohr 54a

Southeastern: Hastings 49

Water-level measurements. Alaska

See fig. 1; table 1

Ground-water development: Cederstrom
Alaska-Continued

Matanuska Valley agricultural area: Trainer 53

Permafrost and ground water: Hopkins 55

Geologic map.

Matanuska Valley: Trainer 53

Angaur Island, Palau Islands: Wentworth 55 Aquifer hydraulics. See Hydraulics of aquifers. Aquifer tests. See Hydraulics of aquifers.

Aretic.

Occurrence and development of ground water in permafrost regions: Cederstrom 53

Arizona.

Effect of drought in Safford Valley: Cushman, R. L., 55

Problems relating to use of ground water: Halpenny 52

Water use by phreatophytes, Gatewood 50, Turner 52

Areal reports.

Cactus Flat-Artesia area, Graham County: Halpenny $47 \mathrm{~b}$

Chiu Chuischu area, Pinal County: Yost 58

Chuska Mountains area, Apache County: Harshbarger $\mathbf{5 4}$

Deer Valley, Maricopa County: Bluhm 49

Doney Park-Black Bill Park area, Coconino County: Feth 53

Douglas basin, Cochise County: Coates 55

Duncan basin, Greenlee County: Halpenny $47 a, 62$

Fort Defiance area, Apache County: Halpenny 49

Gila Bend basin, Maricopa County: Babcock $48 \mathrm{~b}$

Holbrook area, Navajo County: Babcock $47 \mathrm{c}$

Joseph City area, Navajo County: Babcoek $48 \mathrm{a}$

Lower Safford Valley, Graham County: Gatewood 50

Maricopa County: Turner 52

Mogollon Rim region: Feth 54b

Navajo and Hopi Indian Reservations: Halpenny 51; Harshbarger 53

Paradise Valley, Maricopa County: McDonald 47b 
Arizona-Continued

Peeples Valley, Yavapai County: Babcock $47 a$

Rainbow Valley-Waterman Wash area, Maricopa County: Halpenny 52; Wolcott 53

Safford basin, Graham County: Cushman, R. L., 55; Gatewood 50; Halpenny 52; Turner 46

Salt River valley area, Maricopa and Pinal Counties: Halpenny 52; McDonald $47 a$

San Pedro basin, Cochise County: Halpenny 52

San Simon basin, Cochise and Graham Counties: Cushman, R. L. 47; Halpenny $47 \mathrm{~b}, 52$

Santa Cruz basin, Pima and Pinal Counties: Turner 47

Pima and Santa Cruz Counties: Halpenny 52

Sells area, Pima County: Coates 54

Upper Pinal Creek area, Gila County: Hazen 46

Wellton-Mohawk area, Yuma County: Babcock $47 \mathrm{~b}, 48 \mathrm{c}$

Willeox basin, Cochise and Graham Counties: Jones, R. S. 47

Geologic maps.

Cactus Flat-Artesia area, San Simon basin: Halpenny $47 \mathrm{~b}$

Chiu Chuischu area: Yost 53

Deer Valley: Bluhm 49

Douglas basin: Coates 55

Duncan basin: Halpenny $47 \mathrm{a}, 52$

Fort Defiance area: Halpenny 49

Gila Bend basin: Babcock 48b; Halpenny 52

Holbrook area: Babcock $47 \mathrm{c}$

Mogollon Rim region: Feth 54b

Paradise Valley: McDonald $47 \mathrm{~b}$

Peeples Valley: Babcock 47a

Rainbow Valley-Waterman Wash area: Halpenny 52; Wolcott 53

Ranegras Plain area: Halpenny 52

Safford basin: Halpenny 52; Turner 46

Salt River valley: Halpenny 52; McDonald $47 \mathrm{a}$

San Pedro basin: Halpenny 62

San Simon basin: Cushman, R. L. 47; Halpenny 47b; 52

Santa Cruz basin: Halpenny 52

Upper Pinal Creek area: Hazen 46

Wellton-Mohawk area: Babcock 47b, 48c; Halpenny $\mathbf{5 2}$

Willeox basin: Halpenny 52; Jones, R. S., 47

Geophysical surveys.

Resistivity: Chiu Chuischu area: Yost 53 Doney Park-Black Bill Park area: Feth 53

Hydraulics of aquifers.

Coconino sandstone, Joseph City: Babcock $48 \mathrm{a}$
Arizona-Continued
Hydrologic maps.

Chiu Chuischu area: Yost 53

Deer valley: Bluhm 49

Douglas basin: Coates 55

Holbrook area: Babcock $47 \mathrm{c}$

Safford basin: Halpenny 52; Turner 46

Salt River valley: Halpenny 52; McDonald $47 a$

Santa Cruz basin: Halpenny $\mathbf{5 2}$

Upper Pinal Creek area: Hazen 46

Wellton-Mohawk area: Babcock $47 \mathrm{~b}, 48 \mathrm{c}$

Willcox basin: Halpenny $\mathbf{5 2}$

Public water supplies.

Lohr 54b

Quality of water.

Public supplies: Lohr 54b

Water-level measurements.

See fig. 1; table 1

Arkansas.

Ground water in the upper Mississippi Embayment: Schneider 47

Ground-water resources: Baker, R. C., 55

Water-level change, eastern Arkansas: Counts 54

Areal reports.

Ashley County: Hewitt 49

Chicot County: Onellion 55

Columbia County: Tait 53

El Dorado area, Union County: Baker, R. C., 48

Jefferson County: Klein, H., 50

Southwestern: Counts $\mathbf{5 5}$

Geologic maps.

Ashley County: Hewitt 49

Columbia County: Tait 53

El Dorado area: Baker, R. C., 55

Jefferson County: Klein, H., 50

Southwestern: Counts 55

Hydraulics of aquifers.

Claiborne group, Chicot County: Onellion 55

Nacatoch sand, Hope: Counts 55

Quaternary deposits, Ashdown: Counts 55 Chicot County: Onellion 55

Quaternary sand and gravel, Jefferson County: Klein $\mathbf{5 0}$

Sparta sand, El Dorado: Baker, R. C., 55 Jefferson County: Klein 50

Hydrologic maps.

Arkansas: Baker, R. C., 55

Eastern: Baker, R. C., 55; Counts 54

Southwestern: Counts $\mathbf{5 5}$

Arkansas, White, and Red River basins: Lohman 53d

Grand Prairie region: Baker, R. C., 55

Public water supplies.

Description and chemical quality: Hale, H., 47; Lohr 54b

Quality of water.

Public supplies: Lohr 54b

Water-level measurements.

Ses fig. 1; table 1 
Arkansas-White-Red River basins.

Areas of ground-water investigations: Lohman $53 \mathrm{c}$

Bibliography: Lohman 52

Map of availability and depth to ground water: Lohman 53d

Army water supplies. See Military hydrology.

Artesian pressures. See Water levels.

Artesian water.

Southeastern States: Stringfield $\mathbf{5 3}$

Artificial recharge.

Bibliography: Klaer 48a

General principles of artificial groundwater recharge: Meinzer $46 \mathrm{a}$

Ground-water reservoirs: Sayre $48 \mathrm{c}$

Recharge of Texas aquifers: George 52b

Water spreading and recharge wells: Ferris $50 \mathrm{c}$

Induced infiltration.

River infiltration as a source of groundwater supply: Kazmann 48

Stream-bed percolation to collector-type well: Rorabaugh 51

Temperature changes: Rorabaugh 48

Theory: Rorabaugh 48

Water spreading.

Effect of land-management practices: Barksdale $55 \mathrm{~b}$

New Jersey: Barksdale 46

Utah, Bountiful district: Thomas 48, 49b Well injection.

Artificial recharge of a brackish waterwell: Cederstrom $47 \mathrm{~b}$

Florida, Orlando: Unklesbay 46

Kentucky, Louisville: Guyton 46; Rorabaugh $49 \mathrm{~b}$

New York, Long Island: Brashears 46

Texas, El Paso: Scalapino 49; Sundstrom $\mathbf{5 2 b}$

Atolls.

Ifalik Atoll: Arnow 55

Marshall Islands, northern: Arnow 54

Ulithi Atoll: Schlanger 55

Bacteria in ground water.

Quality of ground-water supplies: Thomas $49 a$

Base flow.

California, San Bernardino and eastern San Gabriel Mountains: Troxell 53, 64

Forecasting low flow of streams: Riggs 53

Forecasting seasonal water supplies: Piper 48

Kansas, relation of mineral constituents to stream flow, Saline River: Durum 53

Maryland, ground-water runoff in Beaverdam Creek basin: Meyer, R. R., 55a

Ohio, relation of geology to dry-weather stream flow: Cross 49

Utah and Colorado, Green River: Thomas 520

Bibliography.

Arkansas-White-Red River basins: Lohman 62
Bibliography-Continued

Artificial recharge: Klaer $48 a$

Connecticut: Cushman, R. V., 50b

Electric logging: Richardson 50

Ground-water conservation: Sinnott $\mathbf{5 2}$

Ground-water literature:

Open-file reports, U. S. Geological Survey: Randall $52,53,54 a, 54 b, 65$

Reports, memoranda, and articles, U. S. Geological Survey: Griffin 46, 47, 48a, $48 b, 49,50,53,54,55$

U. S. Geological Survey and cooperating agencies: Waring 47

Hawaii, geology and water resources: MacDonald $47 \mathrm{a}$

Meinzer, O. E., published works: Sayre 49

New York, geology and ground water conditions on Long Island: Brashears $49 a$

Permeability: Johnson, A. I., 55

Salt-water encroachment: Winslow, A. G., 53

Biography.

Meinzer, O. E.: Sayre $48 a, 49$

California.

Base fiow from San Bernardino and eastern San Gabriel Mountains: Troxell 53, 64

Earthquake water-level fluctuations in wells: Davis, G. H., 55

Effect of Arvin-Tehachapi quake on spring and stream flow: Briggs 55

Ground-water in California: Poland 50, 53

Ground-water outflow from Chino basin: Garrett 49

Major ground-water basins: Poland 49

Mud-volcano eruption, Lake City Fot Springs: White, D. E., 65

Storage capacity, Sacramento Valley: Poland 51

Santa Ynez River alluvium: Wilson, $\mathrm{H}$. D., 52

Sutter-Yuba area: Davis, G. H., 52

Water supply in the south coastal basins: Stafford 53; Troxell 51

Areal reports.

Campo, Mesa Grande, La Jolla, and Pauma Indian Reservations, San Diego County: Olmstead 53

Carpinteria basin, Santa Barbara County: Upson 51a

Cuyama Valley, Santa Barbara County: Upson 51b

Fish Lake Valley, Mono and Inyo Counties: Eakin 50

Goleta basin, Santa Barbara County: Upson 51a

Long Beach-Santa Ana area, Long Beach and Orange Counties: Piper 53b, Poland 46

Los Angeles area, coastal basins: Stafford 53 
California-Continued

Lower Lake-Middletown area, Lake County: Upson 55b

Mendota-Huron area, Fresno and Kings Counties: Davis, G. H., 54

Orange County: Poland 47

San Bernardino County, central (tabular data): Burnham 55

San Diego County, eastern (tabular data): Burnham 54

Santa Barbara County (tabular data) : LaRocque 50

Santa Maria Valley area, Santa Barbara County: Worts 51

Santa Ynez River basin: Upson 51c

South-coast basins, Santa Barbara County: Upson $51 \mathrm{a}$

Sutter County: Davis, G. H., 52

Torrance-Santa Monica area, Los Angeles County: Poland 48

Yuba County: Davis, G. H., 52

Geologic maps.

Campo Indian Reservation: Olmsted 53

Carpinteria basin: Upson 51a

Central San Bernardino County: Burnham 55

Cuyama Valley: Upson 51b

Goleta basin: Upson 51a

Lo Jolla Indian Reservation: Olmsted 53 Lower Lake-Middletown area: Upson 55b Mesa Grande Indian Reservation: Olmsted 53

Pauma Indian Reservation: Olmsted 53

Santa Barbara County: Upson 51a

Santa Maria Valley: Worts 51

Santa Ynez River basin: Upson 51c

Torrance-Santa Monica area, Los Angeles County: Poland 48

Sutter-Yuba Counties: Davis, G. H., 52

Hydrologic maps.

Cuyama Valley: Upson $51 \mathrm{~b}$

Long Beach-Santa Ana area: Piper 53b

Santa Barbara County: Upson 51a

Santa Maria Valley: Worts 51

Santa Ynez River basin: Upson 51c

Public water supplies,

Lohr 54b

Quatity of water.

Long Beach-Santa Ana area: Piper 53b

Public supplies: Lohr 54b

Salt-water encroachment in Orange County: Poland 47

Water-level measurements.

See fig. 1; table 1

Santa Barbara County: LaRocque $\mathbf{5 0}$

Caliper logging. See Well logging.

Capillary phenomena.

Infiltration: Smith, W. O., 49

Losses from ground water: Remson 55a

Carolina bays.

Streamlining: LeGrand 53a

Caroline Islands.

Angaur Island: Wentworth
Caroline Islands-Continued

Falalop Island, Ulithi Atoll: Schlanger 65

Ifalik Atoll: Arnow 55

Casing exploration. See Well logging.

Chemistry of ground water. See Geochemistry. Chile.

Azapa Valley: Taylor, G. C., $49 \mathrm{~b}$

Casablanca Basin: Taylor, G. C., 48

Northern: Taylor, G. C., 49c

Geologic maps.

Azapa Valley: Taylor, G. C., $49 \mathrm{~b}$

Casablanca Basin: Taylor, G. C., 48

Hydrologic map.

Azapa Valley: Taylor, G. C., $49 \mathrm{~b}$

Chromium. See Contamination of ground water.

Colorado.

General geology and ground-water resources of the Arkansas basin in Colorado: Lohman 51

Hydrogeologic problem in the proposed Echo Park reservoir: Thomas 53d

Reconnaissance studies of the Green River: Thomas 52c, 53a

Status of ground-water investigations: MeLaughlin 53

Areal reports.

Baca County: McLaughlin 54

Brush area, Morgan County: Brown, R. F., 50

Denver metropolitan area: McLaughlin $55 \mathrm{~b}$

Julesberg area, Sedgwick County: McLaughlin 48

Kansas River basin, Kit Carson, Cheyenne, and Lincoln Counties: Cardwell 53

Parts of Lincoln, Elbert, and El Paso Counties: McLaughlin 46a

Trinidad area, Las Animas County: Powell 52

Geologic maps.

Baca County: MeLaughlin $\mathbf{5 4}$

Brush area: Brown, R. F., 50

Kansas River basin: Cardwell 53

Parts of Lincoln, Elbert, and El Paso Counties: McLaughlin $46 \mathrm{a}$

Hydraulics of aquifers.

Alluvium, Big Sandy Valley: McLaughlin $46 a$

Cheyenne sandstone member of Purgatoire formation, Walsh artesian area: McLaughlin 54

Hydrologic maps.

Arkansas-White-Red River basins: Loh$\operatorname{man} 53 d$

Baca County: McLaughlin 54

Kansas River basin: Cardwell 53

Public water supplies.

Lohr 54b

Quality of water.

Public supplies: Lohr 54b

Water-level measurements.

See fig. 1; table 1 
Connecticut.

Bibliography: Cushman, R. V., 50b

Ground water in Connecticut: Cushman, R. V., 55

Possible ground-water development: Cushman, R. V., 52

Yield of rock wells: Cushman, R. V., $53 \mathrm{~b}$ Expectable: Cushman, R. V., 55

Public water supplies.

Description and chemical quality: Lohr $54 a$

Survey of public ground-water supplies: Brashears $49 \mathrm{~b}$

Quality of water.

Public supplies: Lohr 54 a

Water-level measurements.

See fig. 1; table 1

Contamination of ground-water. See also Saltwater encroachment.

Atomic wastes and their disposal: Warde 55

Chromium: Bennett 52

Gasoline: Cederstrom $47 \mathrm{~d}$

Industrial waste: Piper 53b

Leaky wells: Bennett 52; Williams 48a

Mineralized encroachment from pumping: Williams $48 a$

Oil-field brine: Williams 46a, 49; Piper $53 \mathbf{b}$

Salt-water problem in Texas: George 50

Sanitary quality of ground-water supplies: Thomas $49 \mathrm{a}$

Sulfuric acid: Bennett $\mathbf{5 2}$

Cryopedology. See Permafrost.

Cyclic fiuctuations. See Water levels.

Definitions:

Area of diversion: Klaer $48 \mathrm{~b}$

Basal ground-water: MacDonald $47 \mathrm{~b}$; Stearns, H. T., 46

Capture: Stringfield 51a

Drought: Thomas 54

Effective radius: Jacob 47

Effective saturated thickness: Sniegocki 55

Geologic, hydrologic, and chemical terms used in reports on the ground-water resources and problems of Arizona: Halpenny $47 \mathrm{c}$

Half-journey: Theis 55

Hydraulic diffusivity: Ferris $\mathbf{5 4}$

Potential capillary water loss: Remson 55 a

Recharge wells-“dry" and "wet" types: Brashears 46

River factor: Rorabaugh 48

Specific permeability: Fishel 46

Temperature of equilibrium: Simpson, E. S., 52

Well efficiency: Rorabaugh 53a

Delaware.

Ground-water problems in highway construction and maintenance: Rasmussen 53
Delaware-Continued

Magnitude of ground-water supply: Rasmussen $\mathbf{5 5 a}$

Areal reports.

Delaware: Marine $\mathbf{5 5}$

Delaware River valley: Barksdale 53, 55a

Newark area, New Castle County: Groot 54

Geologic maps.

Delaware: Marine $\mathbf{5 5}$

Newark area: Groot 54

Geophysical surveys.

Resistivity and magnetic, Newark area: Groot $\mathbf{5 4}$

Hydraulics of aquifers.

Major aquifers, estimated ranges in transmissability: Rasmussen 55a

Patuxent sand, Newark: Groot 54

Hydrologic maps.

Delaware: Marine $\mathbf{5 5}$

Public water supplies.

Description and chemical quality: Lohr 54a; Marine 55

Quality of water.

Public supplies: Lohr $54 a$

Water-level measurements.

See fig. 1; table 1

Ground-water levels, 1952; Marine 54

1953: Boggess 55

1954: Coskery 56

District of Columbia.

Public water supplies.

Lohr: 54a

Quality of water.

Public supplies: Lohr 54a

Drainage studies.

Florida, underground drainage of Lake Tarpon: Heath 54b

Montana, Buffalo Rapids irrigation project: Moulder 53

Helena Valley: Lorenz 51

Nebraska, Dutch Flats area: Babcock 51

Pond drainage by wells: LaMoreaux $49 a$ Drought.

Arizona, effect on Safford Valley: Cushman, R. L., 55

Southwestern United States, 1942-53: Thomas 54

Utah, effect on Cedar City Valley: Waite 55

Earth tide. See also Water levels, earth-tide fluctuations.

Tide-producing forces and artesian pressures: George $51 \mathrm{~b}$

Earthquake water-level fiuctuations. See Water levels, seismic fiuctuations.

Electric-log interpretation.

Detection of salt-water contamination: Bennett 52

Estimating quantity and quality of ground water: Barnes, B. A., 47

Porosity determination in situ: Jones, $\mathbf{P}$. H., 51 
Electric-log interpretation-Continued

Principles and applications: Jones, P. H. 62

Quality-of-water estimates: Jones, P. H., 51

Electro-osmosis.

Use in soil stabilization: Rasmussen $5 ?$

Entrance losses. See Hydraulics of wells.

Equipment.

Casing length, device for measuring: Norris 49

Ink-well mercury gage: Jacob 52

Permeameter, for ground-water investigation: Smith, W. O., 55

Variable head: Stallman 52

Piezometer: Visher 53

Slide rule used in applying nonequilibrium formula: Theis 51

Water-level measurement, electric tape: de Laguna 53; Norris 52a

Evapotranspiration.

California, southern mountain drainage areas: Troxell 49

Determination, capillary-loss method: Remson 55a

Inflow-outflow method: Thomas 62c, $52 f$

Utah, Echo Park reservoir: Thomas 52b

Water use by phreatophytes, Safford Valley, Ariz.: Gatewood 50

Maricopa County, Ariz.: Turner 52 Florida.

Age of Tamiami formation: Hoy 52

Artiflcial recharge of artesian limestone at Orlando: Unklesbay 46

Cessation of flow of Kissengen Spring: Peek 51

Economic aspects of ground-water use: Stringfleld $51 \mathrm{~b}$

Ground-water in Florida: Cooper, H. H., 50

Perennial yield, Biscayne aquifer: Parker 51

Principal artesian aquifer: Stringfield 51a

Salt-water encroachment: Parker 55a, $55 \mathrm{c}$

Springs of Florida: Ferguson, G. E., 47

Submarine artesian spring off Florida coast: Stringfield $51 \mathrm{c}$

Areal reports.

Brevard County: Neill 65

Broward County: P'arker 55d

Central and Northern Florida: Cooper, $H$. H., 53

Dade County: Parker 65d

Everglades: Parker 48

Western: Schroeder 54a

Fair Point Peninsula, Santa Rosa County: Heath 51

Fort Lauderdale area, Broward County: Vorhis 48

Manatee County: Peek 55

Florida-Continued

Naples area, Collier County: Klein, H., 54

Palm Beach County: Schroeder 54a; Parker 55d

Pinellas County: Heath 54b

Ruskin area, Hillsborough County: Peek 53

Seminole County: Heath 54a

Southeastern Florida: Parker 55d

Geologic maps.

Brevard County: Neill 55

Everglades region: Parker 48

Florida: Cooper, H. H., 50; Stringfield 51b

Pinellas County: Heath 54b

Southeastern Florida: Parker 55d

Geophysical surveys.

Deep-well current meter, Manatee County: Peek 65

Resistivity, Miami and Fort Lauderdale: Spicer $\mathbf{5 5}$

Hydraulics of aquifers.

Biscayne aquifer, Miami: Warren 55

Biscayne aquifer, Fort Lauderdale: Vorhis 48

Shallow aquifer, Delray Beach: Schroeder $54 \mathrm{~b}$

Shallow artesian aquifer, Naples: Klein 54

Upper aquifer, Fair Point peninsula: Heath 51

Hydrologic maps.

Brevard County: Neill 55

Broward County: Parker 55e

Dade County: Parker 55e; Warren, 55

Florida: Cooper, H. H., 50; Heath 54a; Peek 51; Stringfield 51b, 51c

Fort Lauderdale area: Vorhis 48

Lake Worth area: Schroeder 54b

Manatee County: Peek 55

Miami area: Parker 55e

Naples area: Klein 54

Orlando area: Unklesbay 46

Pinellas County: Heath 54b

Ruskin area: Peek 53

Seminole County: Heath 54a

Southeastern Florida: Parker 55e

Public water supplies.

Description and chemical quality: Lohr 54a

Fort Lauderdale: Vorhis 48

Southern Florida: Parker 47

Quality of water.

Public supplies: Lohr 54a

Southeastern: Love 55

Water-level measurements.

See flg. 1; table 1

Fluctuations. See Water levels.

Fluoride in ground water.

Alabama: LaMoreaux 47, 48b, 50a

Virginia Coastal Plain: Sinnott 50 
Flushing of Aquifers.

Salt water and its relation to fresh ground water: Winslow, A. G., 54a

Texas, Galveston County: Petitt 55

Geochemistry.

Fluoride, origin in Coastal Plain water: Sinnott 50

Genesis, ground water of Virginia Coastal Plain: Cederstrom 46a, 46b

Ground water: Hem $\mathbf{5 0}$

Powder River basin, Wyo. and Mont: Swenson, H. A., 53

Geologic maps. See under state names.

Geologic structure. See Structural control of occurrence.

Georgia.

Ground water for irrigation in Georgia: Herrick, S. M., 46

Streamlining of the Carolina bays: LeGrand 53a

Water-level fiuctuations in sinks: Hendricks 52, 54

Areal reports.

Atlanta region: Herrick, S. M., 49

Atlanta metropolitan area: Carter 51

Clayton County: Herrick, S. M., 49

Coastal Plain, east-central Georgia: LaMoreaux $46 \mathrm{a}, 46 \mathrm{~b}$

Cobb County: Herrick, S. M., 49

De Kalb County, Herrick, S. M., 49

Douglas County: Herrick, S. M., 49

Fulton County: Herrick, S. M., 49

Gwinnett County: Herrick, S. M., 49

Rockdale County: Herrick, S. M., 49

Geologic maps.

Coastal Plain of east-central Georgia: LaMoreaux 46b

Hydrologic maps.

Atlanta area: Carter 51

Public water supplies.

Lohr 54a

Quality of water.

Lohr 54a

Water-level measurements.

See fig. 1; table 1

Geyser.

Regularity of Old Faithful: Fix 49

Glossary.

Definitions of geologic, hydrologic, and chemical terms used in reports on the ground-water resources and problems of Arizona: Halpenny 47c, 52

Graphical methods.

Aquifer compressibility, determination: Jacob 47

Aquifer permeability, determination: Jacob 47

Formation constants, determination: Cooper, H. H., 46

Head losses in wells, determination: Rorabaugh $49 \mathrm{c}, 53 \mathrm{a}$

Interpretation, water-level data: Fishel 55
Graphical methods-Continued

Kansas brines, representation: Jeffords $48 a$

Prediction of evapotranspiration salvage by lowering of water table: Parker $55 d$

Rate of water-level decline versus stage correlated with evaporation rate: Parker 55d

Specific capacity versus cumulative percentage of wells: Mundorff 53

Static head versus chloride content: Heath $54 \mathrm{a}$

Static head versus yield: Heath 54a

Temperature, hardness, chloride, and dissolved solids versus depth: Coines 51

Water-level rise related to precipitation: P'arker 55d

Yield versus well depth below water table: Mundorfi $\mathbf{5 3}$

Ground-water law. See Law relating to ground water.

Ground-water use. See Water use.

Grouting, seepage control: Visher 53

Guadalcanal.

Occurrence of connate water: Baker, $\mathbf{R}$. C., 50

Haiti.

Areal reports.

Cul-de-Sac plain: Taylor, G. C., $49 \mathrm{e}$

Gonaïves plain: Taylor, G. C., 49d., 50

Reconnaissance: Taylor, G. C., $49 \mathrm{a}$

Geologic maps.

Gonaïves plain: Taylor, G. C., 50

Hydrologic maps.

Gonaives plain: Taylor, G. C., 50

Hawaii.

Bibliography, geology and water resources: Macdonald 47a

Areal reports.

Hawaii: Stearns, H. T., 46

Molokai: Macdonald $47 \mathrm{~b}$

Niihau: Stearns, H. T., 47

Geologic maps.

Hawaii: Stearns, H. T., 46

Molokai: Macdonald 47b

Niihau: Stearns, H. T., 47

Highway hydrology.

Ground-water problems in highway construction and maintenance: Rasmussen 53

Importance of ground water studies to highway engineering: Norris 54

History.

Applications of geology to the investigation of our water resources: Sayre $50 a$

Artesian water, southeastern states: Stringfield $\mathbf{5 3}$

Geology and engineering in the production and control of ground water: Meinzer 50 
History-Continued

Ground water: Sayre $\mathbf{5 0 b}$

Lifeblood of the High Plains: Taylor, G. H., $\mathbf{5 3 b}$

Ground-water investigations, the United States: Sayre $48 b$

Mississippi: Lang, J. W., 55a

Permeability concept: Jacob 46a

Scientific management of ground-water resources: Meinzer $\mathbf{4 7 b}$

Hydraulies of aquifers.

Analysis of step-drawdown test of artesian well: Rorabaugh 53a

Evaluation of hydraulics of aquifers: Schaefer 60

Selected references on permeability: Johnson, A. I., 65

Slide rule used in applying nonequilibrium formula: Theis 51

Areal methods.

Flow-net analysis: Bennett $\mathbf{6 2}$

Forchheimer graphical solution: Bennett 52

Pumpage inventory and water-level maps, use in determining aquifer coefficients: Drescher 53a; Foley $\mathbf{5 3}$

Channel methods.

Distance to line source of recharge: Kazmann 46; Rorabaugh 48

Flow conditions near a line sink: Stuart 54

Hydraulics of drains: Ferris $50 \mathrm{a}$

Semilog solution for transmissibility: Rorabaugh 48

Well methods.

Analysis, aquifer-test data: Brown, R. H., 53

Corrections for thin water-table aquifer: Ferris 49

Evaluating formation constants and summarization of well-field history: Cooper, H. H., 46

Ground-water hydraulies, a geophysical aid: Ferris 48

Use in geologic interpretation: Walton 55

Image method: Ferris 48, 49; Rasmussen 52

With infinite series of wells: Stuart 48

Nonsteady flow with constant drawdown: Jacob 52

Prospecting by aquifer tests: Ferris $50 \mathrm{~b}$

Pumpage-increment method: Rasmussen 52

Pumping tests on wells in Iowa: Jeffords 52

Radial flow, leaky artesian aquifer: Jacob $46 \mathrm{~b}$

Speciflc yield from equilibrium test data: Remson 55e

Transmissibility from eyclic fiuctuations: Ferris 51a

Uniform-rate recharge test: Stuart 54
Hydraulics of wells. See also Hydraulies of aquifers.

Aquifer-test method for determining specific yield: Remson $\mathbf{5 5 c}$

Determination of effective radius: Jacob 47

Relation of well diameter to drawdown and yield: Stuart 48

River infiltration to wells: Kazmann 48

Step-drawdown test: Jacob 47; Rorabaugh 49c, 53a

Well-loss determination: Remson $\mathbf{6 5 c ;}$ Rorabaugh 53a

Hydrologic cycle.

Ferris 54; Piper 48, 53a

Hydrologic maps. See also the subheading Hydrologic maps under United States, the various states, and some countries.

State of Nebraska water levels: Schreurs 54

State of Oklahoma, ground-water resexvoirs: Schoff 65

Idaho.

Feasibility of ground-water features, alternate plan for Mountain Home project: Nace $\mathbf{5 5}$

Areal reports.

Aberdeen-Springfield area, Bingham and Power Counties (tabular data): Sisco 54,55

Bingham County, western (tabular data) : Shuter $\mathbf{5 3}$

Dry Creek area, Cassia and Twin Falls Counties (tabular data): West, S. W., 52

Goose Creek basin, Cassia County (tabular data): Mower $\mathbf{5 3 b}$

Jefferson County, western (tabular data) : Barraclough 53

Jerome County, eastern (tabular data): Mower 53a

Michaud Flats, Power County: Stewart 54

Minidoka County: Nace 48

Raft River valley, Cassia County (tabular data): Fader $\mathbf{5 1 b}$

Rathdrum Prairie, Bonner and Kootenai Counties (tabular data): Nace 50

Spokane-Coeur d'Alene River basin: Simons 53

Whitney Terrace area, Ada County: West, S. W., 55

Geophysical surveys.

Seismic, Spokane River valley: Newcomb 53

Hydrologic maps.

Michaud Flats: Stewart $\mathbf{5 4}$

Minidoka County: Nace 48

Whitney Terrace area: West, S. W., 55 Public water supplies.

Lohr 54b

Quality of water.

Public supplies: Lohr 54b 
Idaho-Continued

Water-level measurements.

See fig. 1; table 1

Rathdrum Prairie: Fader 51a Illinois.

Areal reports.

East St. Louis area: Searcy 52

Geologic maps.

East St. Louis area: Searcy $\mathbf{5 2}$

Public water supplies.

Lohr 54a

Quality of water.

Public supplies: Lohr 54a

Water-level measurements.

See fig. 1; table 1

India.

Dudhai area, Kutch: Taylor, G. C., 54

Geologic map.

Dudhai area, Kutch: Taylor, G. C., 54

Hydrological maps.

Dudhai area, Kutch: Taylor, G. C., 54

Rajasthan, western: Taylor, G. C., 52 Indiana.

Ground-water levels: Klaer 49, 50a

Present status of ground-water supplies: Klaer 50b

Areal reports.

Boone County: Brown, E. A., 49

New Albany and Jeffersonville, Floyd and Clark Counties: Rorabaugh 46b, 53b

Noble County: Stallman $\mathbf{5 0}$

South Bend area, St. Joseph County: Klaer $48 b$

Geologic maps.

Boone County: Brown, E. A., 49

Noble County: Stallman $\mathbf{5 0}$

South Bend area: Klaer 48b

Hydraulics of aquifers.

Glaciofiuvial sand and gravel, South Bend: Klaer $48 \mathrm{~b}$

Sand and gravel, Kendallville: Stallman 50

Hydrologic maps.

Boone County: Brown, E. A., 49

Ground-water provinces: Klaer $50 \mathrm{~b}$

Noble County: Stallman $\mathbf{5 0}$

South Bend area: Klaer 48b

Public water supplies.

Description and chemical quality: Lohr $54 a$

South Bend: Klaer 48b

Quality of water.

Public supplies: Lohr. 54a

Water-level measurements.

See fig. 1; table 1

Induced infiltration. See Artificial recharge. Induced recharge. See Artificial recharge.

Infiltration.

Effects of land management: Barksdale $55 \mathrm{~b}$

Hydrology of the San Bernardino and eastern San Gabriel Mountains: Troxell 54
Infiltration-Continued

Pedological relations of infiltration phenomena: Smith, W. O., 49

Infiow-outfiow studies.

Georgia, relation of ground-water levels to pond levels in limestone sinks: Hendricks 54

Relation of ground water to flow of Leona River, Tex.: Livingston $47 \mathbf{a}$

Utah and Colorado, Green River: Thomas $52 \mathrm{c}, 53 \mathrm{a}$

Inkwell mercury gage. See Equipment.

Ion exchange.

Removal of radioactive bases in groundwater fow: Theis $\mathbf{5 5}$

Iowa.

Areal reports.

Webster County: Hale $55 b$

Public water supplies.

Lohr 54b

Quality of water.

Public supplies: Lohr 54b

Water-level measurements.

See fig. 1; table 1

Iron.

Elimination by pumping: Brown, R. F., 50

Hypothesis on origin of a limonite bed: Schneider 49

Irrigation.

Available ground-water supplies, Missouri

River basin: Trylor, G. H., 53a

Rio Grande valley, N. Mex.: Conover 54

Effect on ground water, Wheatland Flats, Wyo.: Littleton 50c

Iwo Jima.

Geology and ground-water resources: Swenson, F. A., 48

Juvenile water.

Availability: McGuinness 54

Kansas.

Contamination from mineralized over fresh water in southeast: Williams $48 \mathrm{a}$

Glacial deposits in northeastern Kansas: Frye 50

Graphical representation of Kansas brines: Jeffords $48 \mathrm{a}$

Ground-water resources of Kansas: Fishel 47

Areal reports.

Barton County: Latta 50

Chase County: O'Connor 51

Cheyenne County: Prescott 52

Cloud County, northern: Fishel 48b

Edwards County: MeLaughlin 49

Film Creek valley, Barber County: Williams $46 \mathrm{a}$

Graham County: Prescott 55

Grant County: MeLaughlin 46c

Greeley County: Prescott 54

Haskell County: McLaughlin 46c 


\section{Kansas-Continued}

Hays, Victoria, Walker, Gorham, and Russell, in Ellis and Russell Counties: Latta 48a

Hutchinson area, Reno County: Williams $46 \mathrm{~b}$

Jackson County: Walters $\mathbf{5 3}$

Jewell County: Fishel 55

Kansas City area: Fishel 48a, 53

Kiowa County: Latta 48b

Lane County: Prescott 51

Lincoln County: Berry 52

Lyon County: O'Connor 51

Marshall County: Walters 54

Medicine Lodge area, Barber County: Williams 46a

MePherson County: Williams 49

Norton County: Frye 49b

Osage County: O'Connor 55

Pawnee County: McLaughlin 49

Pawnee Valley, Pawnee, Ness, and Hodgeman Counties: Fishel $52 b$

Phillips County, northwestern: Frye 49b Republic County: Fishel $48 \mathrm{~b}$

Rice County: Fent 50

Scott County: Waite 47b

Seward County: Byrne 48

Sherman County: Prescott 53

Smoky Hill Valley, Saline, Dickinson, and Geary Counties: Latta 49

Solomon River (North Fork), Mitchell, Osborne, Smith, and Phillips Counties: Leonard 52

South-Central Kansas, MePherson, Harvey, Sedgwick, and Marion Counties: Williams 49

Southwestern: Frye 49a

Stafford County: Latta 50

Stevens County: McLaughlin 46c

Wichita County: Prescott 54

Wichita well-field area: Williams, 47, 49 Geologic maps.

Barton and Stafford Counties: Latta 50

Chase County: O'Connor 51

Cheyenne County: Prescott 52

Graham County: Prescott 55

Grant, Haskell, and Stevens Counties: McLaughlin 46c

Greeley County: Preseott 54

Harvey County: Williams 49

Hutchinson area, Reno County: Williams $46 \mathrm{~b}$

Jackson County: Walters $\mathbf{5 3}$

Jewell County: Fishel 55

Kansas City area: Fishel 48a

Kiowa County: Latta 48b

Lane County: Prescott 51

Lincoln County: Berry 52

Lyon County: O'Connor 53

Marshall County: Walters 54

Medicine Lodge area: Williams $46 \mathrm{a}$

MePherson County: Williams 49

Norton County and northwestern Phillips County: Frye 49b
Kansas-Continued

Osage County: O'Connor 55

Pawnee and Edwards Counties: MeLaugh$\operatorname{lin} 49$

Pawnee Valley: Fishel $52 b$

Republic County and northern Cloud County: Fishel $48 \mathrm{~b}$

Rice County: Fent $\mathbf{5 0}$

Scott County: Waite $47 \mathrm{a}$

Sedgwick County: Williams 49

Seward County: Byrne 48

Sherman County: Prescott 53

Smoky Hill Valley: Latta 49

Solomon River valley, North Fork: Leonard 52

South-central: Williams 49

Wichita and Greeley Counties: Prescott 54

Hydraulics of aquifers.

Alluvium, Arkansas valley at Hutchinson: Williams $46 \mathrm{~b}$

Jewell City: Fishel 55

Kansas City: Fishel 48 a

Little Arkansas Valley at Wichita: Williams 49

Pawnee Valley: Fishel 52b

Republic Valley (laboratory permeabilities): Fishel $48 \mathrm{~b}$

McPherson formation, near Wichita: Williams 49

Ogallala formation, Sherman County: Prescott 53

Near Shields: Prescott 51

Wichita and Greeley Counties: Prescott 54

Pleistocene and Pliocene sand and gravel, Scott County: Waite $47 \mathbf{a}$

Rexroad(?) and Meade formations, Grant County: MeLaughlin $46 \mathrm{c}$

Hydrologic maps.

Arkansas-White-Red River basins : Lohman $53 \mathrm{~d}$

Barton and Stafford Counties: Latta 50

Chase County: O'Connor 55

Cheyenne County: Prescott 52

EIm Creek Valley near Medicine Lodge: Williams $46 \mathbf{a}$

Graham County: Prescott 55

Grant, Haskell, and Stevens Counties: MeLaughlin $46 \mathrm{c}$

Hutchinson area: Williams $46 \mathrm{~b}$

Jackson County: Walters 53

Jewell County: Fishel 55

Kansas City area: Fishel $48 \mathrm{a}$

Kiowa County: Latta $48 b$

Lane County: Prescott 51

Lincoln County: Berry 52

Lyon County: O'Connor 53

Marshall County: Walters 54

Norton County and northwestern Phillips County: Frye $49 \mathrm{~b}$

Osage County: $O^{\prime}$ Connor 55

Pawnee Valley: Fishel 52b 
Kansas-Continued

Pawnee and Edwards Counties: MeLaughlin 49

Republic County and northern Cloud County: Fishel $48 \mathrm{~b}$

Rice County: Fent 50

Scott County: Waite 47a

Seward County: Byrne 48

Sherman County: Prescott 53

Solomon River valley, North Fork: Leonard 52

South-central Kansas: Williams 49

Southwestern Kansas: Frye 49a

Wichita and Greeley Counties: Prescott 54

Wichita well-field area: Williams 49

Public water supplies.

Descriptions and chemical analyses: Lohr $54 \mathrm{~b}$

Wichita: Williams 49

Quality of water.

Contamination by oilfield brine, Elm Creek valley: Williams $46 a$

Oilfield brines, graphic representation: Jeffords $48 \mathrm{a}$

Public supplies: Lohr 54b

Salt-water problems, Wichita: Williams 49

Water-level measurements.

See fig. 1; table 1

Ground-water levels during fioods of 1951: Fishel 52a

Kentucky.

Artificial recharge at Louisville: Guyton 46

Ground water in the upper Mississippi Embayment: Schneider 47

Limestone, solutional features: Hamilton 48

Performance of collector-type well at Louisville: Rorabaugh 51

Areal reports.

Blue Grass region: Palmquist 53

Calvert City-Gilbertsville area, Marshall County: Prée 52

Campbellsville area, Taylor County: Otton $48 \mathrm{a}$

Covington-Newport alluvial area: Walker, E. H., 53

Elizabethtown area, Hardin County: Otton $48 \mathrm{~b}$

Inner Bluegrass region: Hamilton 50

Jackson Purchase region: Prée 53

London area, Laurel County: Otton 48c

Louisville area, Jefferson County: Rorabaugh $46 \mathrm{a}, 46 \mathrm{~b}, 49 \mathrm{a}, 49 \mathrm{~b}, 53 \mathrm{~b}$

Northeastern: Rorabaugh 48

Southwestern: Rorabaugh $46 \mathrm{a}$

Mississippian Plateau region: Brown, R. F., 54

Paintsville area, Johnson County: Baker, J. A., 55

Western Coal region: Maxwell 54
Kentucky-Continued

Geophysical surveys.

Resistivity, Louisville: Rorabaugh $\mathbf{4 6 a}$

Geologic maps.

Bourbon County: Hamilton 50

Elizabethtown area: Otton $48 \mathrm{~b}$

Fayette County: Hamilton $\mathbf{5 0}$

Jessamine County: Hamilton 50

London area: Otton $48 \mathrm{c}$

Louisville area: MacCary 55

Paintsville area: Otton $48 \mathrm{~b}$

Scott County: Hamilton 50

Southwestern Louisville: Rorabaugh $46 \mathrm{a}$

Hydrologic maps.

Bourbon County: Hamilton 50

Campbellsville area: Otton 48a

Elizabethtown area: Otton $48 \mathrm{~b}$

Fayette County: Hamilton $\mathbf{5 0}$

Jessamine County: Hamilton 50

Louisville: Rorabaugh 49b, 53b

Northeastern: Rorabaugh 48

Southeastern: Rorabaugh $46 \mathrm{a}$

Scott County: Hamilton 50

Hydraulies of aquifers.

Breathitt and Lee formations, Paintsville area: Baker, J. A., $\mathbf{5 5}$

Ohio Valley alluvium, Louisville: Rorabaugh 48

Public water supplies.

Blue Grass region: Palmquist 53

Description and chemical quality: Lohr $54 a$

Jackson Purchase region: Prée 53

Mississippian Plateau region: Brown, $\mathbf{R}$. F., 54

Westein Coal region: Maxwell 54

Quality of water.

Bluegrass region: Palmquist 53

Changes due to artificial recharge, Louisville: Rorabaugh $49 \mathrm{~b}$

Jackson Purchase region: Prée 53

Mississippian Plateau region: Brown, $\mathbf{R}$. F., 54

Public supplies: Lohr 54a

Western Coal region: Maxwell 54

Water-level measurements.

See fig. 1; table 1

Land management.

Effect on ground water: Barksdale $55 \mathrm{~b}$

Law relating to ground water.

Conservation: Sinnott $\mathbf{5 2}$

Hydrologic aspects: Broadhurst, W. L., 54; MeLaughlin 55 a

Legal and economic aspects of underground waters: Fiedler $\mathbf{5 0}$

Water law, United States: MeGuinness $51 b$

Water rights, areas of ground-water mining: Thomas $55 a$

Limestone hydrology.

Georgia, relation of ground-water levels to pond levels in limestone sinks: Hendricks 52, 54 
Limestone hydrology-Continued

Kentucky, Bluegrass region: Hamilton $\mathbf{5 0}$ Solution features near Lexington: Hamilton 48

New York, Schoharie County: Berdan 48 Texas, development of limestone aquifers, Comal County: George 48, 52a

Louisiana.

Industrial use of ground water: Turcan 52,55

Rice irrigation with ground water: Jones, P.' H., $47 \mathrm{a}$

Areal report8.

Acadia Parish: Jones, P. H., 54b

Alexandria area, Rapides Parish: Klug 55

Allen Parish: Jones, P. H., 54b

Baton Rouge area: Meyer, R. R., 55b

Beauregard Parish: Jones, P. H., 54b

Calcasieu P'arish: Jones, P. H., 54b

Cameron Parish: Jones, P. H., 54b

Evangeline Parish: Jones, P. H., 54b

Iberia Parish: Jones, P. H., 54b

Jefferson Davis Parish: Jones, P. H., 54b

Lafayette Parish: Jones, P. H., 54b

Monroe area, Ouachita Parish: Jones, P. H., $47 \mathrm{~b}$

Parish planning reports (with groundwater sections): Louisiana Dept. Public Works

Southwestern: Jones, P. H., 54b; Turcan 50

St. Landry P'arish: Jones, P. H., 54b

St. Martin Parish: Jones, P. H., 54b

St. Mary Parish: Jones, P. H., 54b

Vermilion Parish: Jones, P. H., 54b

Vermilion River basin: Jones, P. H., 54a

Geologic maps.

Baton Rouge area: Meyer, R. R., 55b

Southwestern: Jones, P. H., 54b

Hydraulics of aquifers.

Catahoula formation, Alexandria: Klug 55

Chicot aquifer, near Crowley: Fader $\mathbf{6 5}$ Southwestern Louisiana: Jones, P. H., $54 \mathrm{~b}$

"400", "600", "800", "1200", "1700", and "2000-ft" sands. Baton Rouge area: Meyer, R. R., 55b

Hydrologic maps.

Arkansas-White-Red River basins: Lohman $53 d$

Monroe area: Jones, P. H., 47b

Southwestern: Fader 54, 55; Jones, P. H., 47a, 54b; Turcan 50

Vermilion River basin: Jones, P. H., 54a Public water supplies.

Description and chemical quality: Lohr $54 \mathrm{~b}$

General: Turcan 53

Quality of water.

Public supplies: Lohr 54b

Temperature studies: Meyer, R. R., $\mathbf{5 5 b}$

Louisiana-Continued

Water-level measurements.

See fig. 1; table 1

Maine.

Public water supplies.

Description and chemical quality: Lohr $54 a$

Survey of public ground-water supplies: Brashears $49 \mathrm{~b}$

Quality of water.

Public supplies: Lohr $54 a$

Water-level measurements.

See fig. 1; table 1

Maps. See also Geologic maps and Hydrologic maps, subheads under United States and state names.

North America, southern border of permafrost: Cederstrom 53

U. S. S. R., distribution of permafrost: Cederstrom 53

Marshall Islands.

Hydrology of northern islands: Axnow 54 Maryland.

Areal reports.

Anne Arundel County: Brookhart 49; Otton 55

Baltimore area: Bennett $46 \mathrm{~b}, 52$

Calvert County: Otton 55; Overbeck 51

Carroll County: Bennett 46a

Charles County: Otton 55; Overbeck 48

Frederick County: Bennett 46a

Garrett County: Overbeck 54

Howard County: Dingman 54b

Montgomery County: Dingman 54b

Prince Georges County: Meyer, G., 52; Otton 55

Salisbury area, Wicomico County: Meyer, R. R., $55 a$

Somerset County: Rasmussen $\mathbf{5 5 b}$

Southern Maryland: Otton 55

St. Marys County: Ferguson, F. F., 53, Otton 55

Wicomico County: Rasmussen 55b

Worcester County: Rasmussen $55 \mathrm{~b}$

Geologic maps.

Anne Arundel County: Brookhart 49

Baltimore area: Bennett 52

Calvert County: Overbeck 51

Charles County: Overbeck 48

Prince Georges County: Meyer, G., 62

Somerset County: Rasmussen $\mathbf{5 5 b}$

Southern Maryland: Otton 65

St. Marys County: Ferguson, H. F., 53

Wicomico County: Rasmussen 55b

Worcester County: Rasmussen $\mathbf{5 5 b}$

Geophysical surveys.

Electric, caliper, and mud-salinity logging in test wells at Baltimore: Bennett 52

Hydraulics of aquifers.

Aquia greensand, Southern Maryland: Otton 65

"400-ft" aquifer, Cambridge: Rasmussen 52 
Maryland-Continued

Magothy formation, Southern Maryland: Otton 55

Manokin aquifer, Princess Anne, Ocean City, and Snow Hill: Rasmussen 55b

Patapsco formation, Glen Burnie: Brookhart 49

Patapseo and Raritan formations, Southern Maryland: Otton $\mathbf{5 5}$

Patuxent formation, Baltimore: Bennett 52

Southern Maryland: Otton 55

Pleistocene and Pliocene(?) formations, Salisbury and Ocean City: Rasmussen $55 b$

Pocomoke aquifer, Pocomoke City and Ocean City: Rasmussen 55b

Hydrologic maps.

Baltimore area: Bennett 52

Southern Maryland: Otton $\mathbf{5 5}$

Public water supplies.

Lohr 54a

Quality of water.

Public supplies: Lohr 54a

Salt-water relations, Baltimore: Bennett 52

Southern Maryland: Otton $\mathbf{5 5}$

Massachusetts.

Ground-water resources of Cape Cod: Halberg 48

Water-table ponds: Halberg 49

Yield of rock wells: Cushman, R. V., 53b

Areal reports.

Boston area: Halberg 50

Cambridge area: Halberg 49

Cape Cod: Halberg 48

Public water supplies.

Description and chemical quality: Lohr $54 a$

Survey of public ground-water supplies: Brashears $49 \mathrm{~b}$

Quality of water.

Public supplies: Lohr 54a

Water-level measurements.

See fig. 1; table 1

Methods of investigation. See also Graphical methods and Equipment.

Altitudes, altimeter determination: Lane 53

Analysis, aquifer-test data: Brown, R. H., 53

Applications of geology to water-resource investigations: Sayre $50 \mathrm{a}$

Areal studies: Stewart $\mathbf{5 4}$

Calibration of soil-moisture blocks: Remson $55 \mathrm{~b}$

Capillary-loss determination: Remson 55a

Closed basins: Thomas $51 \mathrm{~b}$

Determination of degree of connection between aquifer and river: Rorabaugh 48

Electric continuity method of measuring casing length: Norris 49
Methods of investigation-Continued

Electric-log interpretation: Barnes, B. A., 47; Jones, P. H., 52

Estimation of ground-water supply: Williams 47

Evaluation of formation constants and summarizing well-field history: Cooper, H. H., 46

Evaluation of hydraulics of aquifers: Schaefer 50

Geology and engineering in the production and control of ground water: Meinzer 50

Ground water: Sayre $50 \mathrm{~b}$

Head losses in wells, determination: Jones, P. H., 52; Rorabaugh 49c; 53a

Hydrologic interpretation of maps: Thomas 53d

Hydrology, relation to economic geology: Meinzer $46 \mathrm{~b}$

Infiow-outflow method: Thomas 52f

Land management, effect on ground water: Barksdale $\mathbf{5 5 b}$

Measurements - how made, how used: Sehoff 51a

Methods and results of ground-water investigation, arid parts of the United States: Thomas 53b

Piezometer installation: Visher 53

Rating curve, ground-water outflow: Garrett 49

Reconnaissance estimation of recharge and discharge: Eakin $\mathbf{5 0}$

Relations among well depth, topography, and well yield: Mundorff $48 \mathrm{~b}$

Sampling procedures for rotary-drilled wells: Gordon 49

Sedimentation and ground water: Foley 50

Suggestions for research in ground-water hydrology: Meinzer 47a

Temperature as a geophysical guide: Rorabaugh 48

Tests for salt-water encroachment: Bennett 52

Water budget: Ferris 49

Water-level measurement, access ports for measurements in wells: Newcomb 51a

Air-line method: Lohman 54

Water levels, adjustment for density: Parker 55c

Interpretation of fluctuations: Fishel 55

Well exploration: Rima 55

Yield of bedrock related to type of overburden: E. S. Simpson 52

Michigan.

Mine-drainage studies, iron ranges: Stuart 51

Areal reports.

Benton Harbor area, Berrien County: Stuart $45 b$ 
Michigan-Continued

Bessemer area, Gogebic County: E. A. Brown 51

Detroit area, Wayne, Washtenaw, Oakland, and Macomb Counties: Wisler 52

Grand Rapids area, Kent County: Stramel 54

Iron River district, Iron County: Stuart 48

Lansing area, Ingham, Clinton, and Eaton Counties: Stuart $45 a$

Marquette iron-mining district, Marquette County: Stuart 64

Oakland County, southeastern: Ferris 54 Ypsilanti area, Washtenaw County: McGuinness 49

Geologic maps.

Bessemer area: Brown, E. A., 61

Detroit area: Wisler 52

Grand Rapids area: Stramel 54

Iron River district: Stuart 48

Marquette iron-mining district: Stuart $\mathbf{5 4}$

Southeastern Oakland County: Ferris 54

Hydraulics of aquifers.

Glacial overburden, Iron County: Stuart 48

Marquette iron-mining district: Stuart 54

Glacial sand and gravel, Benton Harbor: Stuart $45 b$

Bessemer: Brown, E. A., 51

Flint: Ferris 48

Pontiac and Birmingham: Ferris 54

Ypsilanti: McGuinness 49

Pennsylvanian sandstone, Lansing: Stuart $45 a$

Rocks in Lake Superior district: Stuart 54

Hydrologic maps.

Detroit area: Wisler 52

Iron River district: Stuart 48

Lansing area: Stuart $45 \mathrm{a}$

Marquette iron-mining district: Stuart 54

Public water supplies.

Lohr 54a

Quality of vater.

Public supplies: Lohr 54a

Quantitative studies.

Quantitative approach: Ferris $\mathbf{5 5}$.

Water-level measurements.

See fig. 1; table 1

Military hydrology.

Ground-water problems and their relation to Army water-supply installations: Fiedler 48

Mine-water studies.

Alabama, red-iron-ore district: Simpson, T. A., 55

Aquifer test for evaluation of mine dewatering problem: Stuart $\mathbf{5 5}$
Mine-water studies-Continued

Michigan, iron ranges: Stuart 51

Iron River district: Stuart 48

Marquette district: Stuart 64

Oklahoma, lead-zine mines in Ottawa County: Reed, E. W., 55

Southeastern states: DeBuchananne 50

Tennessee, eastern zinc district: Kent $\mathbf{5 0}$

Mining of ground water.

Water rights: Thomas $\mathbf{5 5 a}$

Minnesota.

Current ground-water work: Akin 50

Areal reports.

Clay County: Dennis 49b

Cloquet area, Carlton County: Akin 62b

Minneapolis-St. Paul area: Prior 63

Moorhead area, Clay County: Byers 46

Traverse County, northwestern: Paulson 53

Wilkin County, southwestern: Paulson 58

Geologic maps.

Cloquet area: Akin $52 \mathrm{~b}$

Geophysical survey.

Resistivity, Cloquet: Akin 52b

Hydraulics of aquifers.

Glacial drift, Moorhead: Dennis 49b

Glacial outwash, Cloquet: Akin $62 \mathrm{~b}$

Hydrologic maps.

Cloquet area: Akin 52b

Minneapolis-St. Paul: Prior 63

Public water supplies.

Lohr: 54b

Quality of water.

Public supplies: Lohr 54b

Water-level measurements.

See fig. 1; table 1

Mississippi.

Ground water for the future: Lang, $J$. W., 55b

Ground water in the upper Mississippi Embayment: Schneider 47

Ground-water supplies for industry: Lang, J. W., 55a

Areal reports.

Alluvial plain, northwestern Mississippi: Brown, G. F., 47

Bolivar County: Brown, G. F., 47

Carroll County: Brown, G. F., 47

Coahoma County: Brown, G. F., 47

De Soto County: Brown, G. F., 47

Grenada County: Brown, G. F., 47

Folmes County: Brown, G. F., 47

Humphreys County: Brown, G. F., 47

Issaquena County: Brown, G. F., 47

Leflore County: Brown, G. F., 47

Mississippi: Lang, J. W., $55 \mathrm{~b}$

Panola County: Brown, G. F., 47

Quitman County: Brown, G. F., 47

Sharkey County: Brown, G. F., 47

Sunflower County: Brown, G. F., 47

Tallahatchie County: Brown, G. F., 47

Tate County: Brown, G. F., 47

Tunica County: Brown, G. F., 47

Warren County: Brown, G. F., 47 
Mississippi-Continued

Washington County: Brown, G. F., 47

Yazoo County: Brown, G. F., 47

Yazoo delta: Brown, G. F., 47

Geologic maps.

Northwest Mississippi: Brown, G. F., 47

Hydrologic maps.

Northwestern Mississippi: Brown, G. F., 47

Public water supplies.

Lohr 54a

Quality of water.

Public supplies: Lohr 54a

Water-level measurements.

See fig. 1; table 1

Missouri.

Ground water in the upper Mississippi Embayment: Schneider 47

Areal reports.

Kansas City area: Fishel 53

St. Louis area: Searcy 52

Hydrologic maps.

Arkansas-White-Red River basins: Lohman 53d

Public water supplies.

Lohr 54b

Quality of water.

Public supplies: Lohr 54b

Water-level measurements.

See fig. 1; table 1

Montana.

Ground water in Montana: Swenson, F. A., 53

Areal reports.

Buffalo Rapids project, Dawson and Prairie Counties: Moulder 53

Helena Valley, Lewis and Clark, Jefferson, and Broadwater Counties: Lorenz 51

Lower Yellowstone Valley, Custer, Dawson, and Prairie Counties: Torrey 51

Missouri valley, Roosevelt, McCone, Richland, and Valley Counties: Swenson, F. A., 55

Geologic maps.

Buffalo Rapids project: Moulder 53

Helena Valley: Lorenz 51

Lower Yellowstone River valley: Torrey 51

Missouri Valley in northeastern Montana: Swenson, F. A., 55

Geophysical surveys.

Resistivity, Medicine Lake area: Edwards 51

Hydraulics of aquifers.

Terrace gravel, Buffalo Rapids project: Moulder 58

Hydrologic maps.

Buffalo Rapids project: Moulder 53

Helena Valley: Lorenz 51

Public water supplies.

Lohr 54b

Quality of water.

Public supplies: Lohr 54b
Montana-Continued

Relation to depth and irrigation suitability: Torrey 51

Water-level measurements.

See fig. 1; table 1

Nebraska.

Ground-water resources: Taylor, G. H. $52 \mathrm{~b}$

Areal reports.

Box Butte County: Nace 53

Clay County: Keech 55

Dutch Flats area, Scotts Bluff and Sioux Counties: Babeock 51

Lower Platte River valley: Waite $48 \mathrm{~b}$, 49

Merrick County: Sniegocki 55

Middle Loup division, Blaine, Custer, Valley, Sherman, and Howard Counties: Brown, D. W., 55

Prairie Creek unit, Merrick, Nance, Platte, and Howard Counties: Sniegocki 55

Pumpkin Creek area, Morrill and Banner Counties: Babcock 52b

Republican and Frenchman River valleys: Waite $48 \mathrm{~b}$

Sand Hills area: Lohman $53 a$

Wood River unit, Buffalo and Hall Counties: Keech 52

Geologic maps.

Dutch Flats area: Babcock 51

Prairie Creek unit: Sniegocki 55

Pumpkin Creek area: Babeock 52b

Hydraulics of aquifers.

Alluvium, lower Platte Valley: Waite 49 Redington: Babcock 52b

Terrace deposits, Dutch Flats area: Babcock 51

Hydrologic maps.

Box Butte County: Nace 53

Clay County: Keech 55

Dutch Flats area: Babcock 51

Lower Platte Valley: Waite 48a, 49

Middle Loup division, lower Platte basin: Brown, D. W., 55; Keech 52

Nebraska: Schreurs 54

Prairie Creek unit: Sniegocki 55

Republican and Frenchman Valleys: Waite $48 \mathrm{~b}$

Sargent unit: Brown, D. W., 55

Wood River unit: Keech $\mathbf{5 2}$

Public water supplies.

Lohr 54b

Quality of water.

Irrigation suitability, Box Butte County: Nace 53

Dutch Flats area: Babcock 51

Pumpkin Creek area: Babcock 52b

Public supplies: Lohr 54b

Water-level measurements.

See fig. 1 ; table 1

Lower Platte River valley: Waite 48a 
Nevada.

Geochemical results, Steamboat Springs: Brannock 48

Ground water in Nevada: Robinson, $T$. W., $49 \mathrm{a}$

Sources of heat, water supply, and mineral content, Steamboat Springs: White, D. E., 48, 50

Areal reports.

Big Smoky Valley: Robinson, T. W., 53a

Buena Vista Valley, Pershing County: Loeltz $\mathbf{5 5}$

Clover and Independence Valleys, Elko County: Eakin 51b

Elko area, Elko County: Fredericks 47

Fish Lake Valley, Esmeralda County: Eakin 50

Goshute-Antelope Valley, Elko County: Eakin 49

Las Vegas and Indian Spring Valleys, Clark County (tabular data): Maxey 46

Las Vegas, Pahrump, and Indian Spring Valleys, Clark and Nye Counties: Maxey 47, 48

Lovelock Valley, Pershing County: Robinson, T. W., 46

Meadow Valley Wash, Lincoln County: Phoenix 48

Paradise Valley, Humboldt County: Loeltz 49

Railroad, Hot Creek, Reveille, Karwich, and Penoyer Valleys, Nye, Lincoln, and White Pine Counties: Maxey 50

Ruby Valley, Flko and White Pine Counties: Eakin 51a

Smith Valley, Lyon and Douglas Counties: Loeltz 53

Spanish Spring and Sun Valleys, Washoe County: Robinson, T. W., 48

Steamboat Springs: Brannock 48; White, D. E., 48,50

Verdi, Washoe County: Robinson, T. W., 51

White River valley, White Pine, Nye, and Lincoln Counties: Maxey 49

Geologic maps.

Buena Vista Valley: Loeltz 55

Clover and Independence Valleys: Eakin $51 b$

Elko area: Fredericks 47

Goshute-Antelope Valley: Eakin 49

Las Vegas, Pahrump, and Indian Spring Valleys: Maxey 48

Meadow Valley Wash: Phoenix 48

Railroad, Hot Creek, Reveille, Kawich, and Penoyer Valleys: Maxey 50

Ruby Valley: Eakin 51a

Smith Valley: Loeltz 53

Verdi: Robinson, T. W., 51

White River valley: Maxey 49

Hydraulics of aquifers.

Eldorado limestone, Eureka: Stuart 55

Humboldt formation, Elko: Fredericks 47

Nevada-Continued

Hydrologic maps.

Buena Vista Valley: Loeltz 55

Goshute-Antelope Valley: Eakin 49

Las Vegas, Pahrump, and Indian Spring Valleys: Maxey 48

Lund: Maxey 49

Paradise Valley: Loeltz 49

Smith Valley: Loeltz 53

Verdi: Robinson, T. W., 51

Public water supplies.

Lohr 54b

Quality of water.

Public supplies: Lohr 54b

Water-level measurements.

See fig. 1; table 1

Nevada valleys, 1913-45: Robinson, T. W., 47

New Hampshire.

Public water supplies.

Description and chemical quality: Lohr $54 a$

Survey of public ground-water supplies: Brashears $49 \mathrm{~b}$

Quality of water.

Public supplies: Lohr 54a

Water-level measurements.

See fig. I; table 1

New Jersey.

Artificial recharge of productive aquifers: Barksdale 46

Availability of ground water in lower Delaware basin: Barksdale 53

Ground-water depletion: Barksdale 49

Ground-water problems in the Philadelphia area: Graham 50a

Areal reports.

Camden area: Graham 50a

Delaware River valley: Barksdale 53, 55a

Newark area: Herpers 51

Pine Barrens area: Barksdale 52

Geologic maps.

Newark area: Herpers 51

Hydrologic maps.

Newark area: Herpers 51

Public water supplies.

Description and chemical quality: Lohr $54 \mathrm{a}$

Quality of water.

Public supplies: Lohr 54a

Water-level measurements.

See fig. 1; table 1

New Mexico.

Brine diversion to improve quality of Pecos River water: Hale, W. E., 54

Ground-water resources: Conover $\mathbf{5 1}$

Navajo County: Harshbarger 53

Possible flow from Rito Resumidera to Poleo Canyon Spring: Hollander 54

Possible improvement of river water by diversion of brine, Malaga Bend: Hale, W. E., 54

Thermal waters, Hot Springs artesian basin: Theis 42 
New Mexico-Continued

Areal reporte.

Carlsbad airport, Eddy County: Hale, W. E., 42

Chuska Mountains area, San Juan County: Harshbarger 54

Colfax County, eastern: Griggs 48

Curry County: Howard 54

Deming, Luna County: Murray 42

Eddy County: Hendrickson 52

Fort Wingate, McKinley County: Callahan 55

High Plains: Gaum 63

Hot Springs artesian basin, Sierra County: Theis 42

Lea County, northern: Conover $42 \mathrm{~b}$

Llano Estacado: Gaum 53

Malaga Bend, Eddy County: Hale, W. E., 54

Mimbres Valley, Luna County: Conover $42 a$

Navajo and Hopi Indian Rerservations: Halpenny 51; Harshbarger 53

Portales Valley, Roosevelt County: Conover $42 \mathrm{c}$

Rattlesnake Springs, Eddy County: Hale, W. E., 55a

Rincon and Mesilla Valleys, Dona Ana County: Conover 54

San Miguel County: Griggs 51

Socorro County, northeastern: Spiegel $\mathbf{5 5}$

South-central New Mexico: Conover 55

Geologic maps.

Eastern Colfax County: Griggs 48

Eddy County: Hendrickson 52

Hot Springs artesian basin: Theis 42

Rattlesnake Springs: Hale, W. E., 55a

San Miguel County: Griggs 51

Hydraulics of aguifers.

Alluvium, Rincon and Mesilla Valleys: Conover 54

Magdalena limestone, Hot Springs: Theis 42

Ogallala formation, Colfax County: Griggs 48

Quaternary alluvium, Mimbres Valley: Conover 42a

Quaternary gravel, Deming: Akin 42; Murray 42

Rustler formation, Malaga Bend: Fale, W. E., 54

Hydrologic maps.

Arkansas-White-Red River basins: Lohman 53d

Dona Ana County: Conover 54

Eastern Colfax County: Griggs 48

Eddy County: Hendrickson 52

Hot Springs artesian basin: Theis 42

Lea County: Conover 42b

Mimbres Valley: Conover 42a, 51

Portales Valley: Conover 42c, 51

Rattlesnake Springs: Hale, W. E., 55a

Roswell basin: Conover 51

San Mignel County: Griggs 51
New Mexico-Continued

Socorro County, northeastern: Spiegel 55

South-central New Mexico: Conover 65

Public water supplies.

Lohr 54b

Quality of water.

Improvement of river water by diversion of brine, Malaga Bend: Hale, W. E., 64

Public supplies: Lohr 54b

Water-level measurements.

Deming test well: Murray 42

New York.

Bibliography, geology and ground water of Long Island: Brashears $49 \mathrm{a}$

Buried channels, Albany-Schenectady area: Simpson, E. S., 49

Configuration of the rock floor, western Long Island: de Laguna 46

Geologic correlation of well logs, Kings County: de Laguna 48

Long Island: Perlmutter 49

Geologic history, Long Island: de Laguna $49 \mathrm{a}$

Ground-water sources, Long Island: Upson $55 a$

Hydrology of limestone terrane, Schoharie County: Berdan 48

Origin of Gardiners clay: Weiss 54

Records of wells, Queens County: Roberts 47

Recovery of ground-water level, Brooklyn: Lusezynski $\mathbf{6 0}$

Areal reports.

Albany County: Arnow 49

Bronx County: Perlmutter 53

Broome County, southwestern: Brown, $\mathbf{R}$. H., 46

Buffalo-Niagara Falls region, Erie and Niagara Counties: Reck 52

Columbia County: Arnow 51b

Cortland quadrangle, Cortland County: Asselstine 46

Delaware River valley: Barksdale 552

Fulton County: Arnow 51a

Greene County: Berdan 55

Long Island: de Laguna 49b, Lusezynski 51

Montgomery County: Jeffords 50

New York County: Perlmutter 53

Rensselaer County: Cushman, R. V., 50a

Richmond County: Perlmutter 53

Rochester area, Monroe County: Grossman 53

Schenectady County: Simpson, E. S., 52

Schoharie County: Berdan 50

Seneca County: Mozola 51

Washington County: Cushman, R. V., 53a

Wayne County: Griswold 51

Westchester County: Asselstine, E. S., 65 Geologic maps.

Albany-Schenectady area: Simpson, E. S., 49 
New York-Continued

Bedrock surface, western Long Island: de Laguna 46

Columbia County: Arnow 51b

Rochester area: Grossman 53

Schenectady County: Simpson, E. S., 52

Seneca County: Mozola 51

Wayne County: Griswold 51

Geophysical surveys.

Resistivity and seismic, Fulton County: Arnow 51a

Washington County: Cushman, R. V., $53 \mathbf{a}$

Hydraulics of aquifers.

Gravel aquifer, Lyons: Griswold 51

Mohawk Valley at Schenectady: Simpson, E. S., 52

Sand and gravel, Fenton: Brown, R. H., 46

Hydrologic maps.

Buffalo-Niagara Falls region: Reck 52

Kings County: Lusezynski 52

Long Island: Lusczynski 51, 52

Public water supplies.

Brooklyn: Lusczynski 52

Description and chemical quality: Lohr $54 a$

Quality of water.

Public supplies: Lohr $54 a$

Water-level measurements.

See fig. 1; table 1

Nitrate in ground water.

Alabama Coastal Plain: LaMoreaux 50b

Texas: George 51a

North Carolina.

Brackish water and its structural implications, Great Carolina Ridge: LeGrand $55 \mathbf{a}$

Flood-plain deposits as source of groundwater supplies: Mundorff $\mathbf{6 0}$

Solution depressions in diorite: LeGrand $52 a$

Streamlining of the Carolina bays: LeGrand $53 \mathbf{a}$

Areal reports.

Alamance County: Mundorff $48 \mathrm{~b}$

Alexander County: LeGrand 54

Bladen County: LeGrand 55a

Cabarrus County: LeGrand $52 \mathrm{c}$

Cape Fear River basin: Mundorff $47 \mathrm{~b}$

Caswell County: Mundorff $48 \mathrm{~b}$

Catawba and Broad River basins: Mundorff 49

Catawba County: LeGrand 54

Charlotte area: LeGrand 52c, 55b

Cleveland County: LeGrand 52e

Davidson County: LeGrand 54

Davie County: LeGrand 54

Edgecombe County: Mundorff 46

Elizabeth City area, Pasquotank County: Mundorff $47 \mathrm{e}$

Forsyth County: Mundorff $48 b$

French Broad River basin: LeGrand $\mathbf{5 0}$

Gaston County: LeGrand 52c
North Carolina-Continued

Greensboro area: Mundorff $48 \mathrm{~b}$

Guilford County: Mundorff 48b

Halifax County and area: Mundorff 46

Hiwassee basin: LeGrand $\mathbf{5 3 b}$

Iredell County: LeGrand 54

Lincoln County: LeGrand 52c

Little Tennessee basin: LeGrand $53 b$

Mecklenburg County: LeGrand 52c

Nash County: Mundorff 46

Neuse River basin: Mundorff $47 \mathrm{a}$

Northampton County: Mundorff 46

North Carolina: Mundorff 45

Polk County: LeGrand 52c

Roanoke and Tar River basins: LeGrand $52 b$

Rockingham County: Mundorff $48 \mathrm{~b}$

Rowan County: LeGrand 54

Rutherford County: LeGrand 52c

Statesville area: LeGrand 54

Stokes County: Mundorff $48 \mathrm{~b}$

Wilson County: Mundorff 46

Yadkin-Pee Dee River basin: Mundorff $48 \mathrm{a}$

Geologic maps.

Alexander County: LeGrand 54

Cabarrus County: LeGrand 62e

Cape Fear River basin: Mundorff $47 \mathrm{~b}$

Catawba County: LeGrand 54

Cleveland County: LeGrand 52c

Coastal Plain: LeGrand 55c

Davidson County: LeGrand 54

Davie County: LeGrand 54

Gaston County: LeGrand 52c

Halifax area: Mundorff 46

Iredell County: LeGrand 54

Lincoln County: LeGrand 52c

Mecklenburg County: LeGrand 52c, 55b

Neuse River basin: Mundorff $47 \mathrm{a}$

Polk County: LeGrand 52c

Roanoke and Tar River basins: LeGrand $52 b$

Rowan County: LeGrand 54

Rutherford County: LeGrand 52e

Yadkin-Pee Dee River basin: Mundorff $48 \mathrm{a}$

Hydrologic maps.

Coastal Plain area: Mundorff 45

Elizabeth City area: Mundorff $47 \mathrm{c}$

Halifax area: Mundorff 46

North Carolina: Mundorff 45

Public water supplies.

Lohr 54a

Quality of water.

Public supplies: Lohr 54a

Water-level measurements.

See fig. 1; table 1

North Dakota.

Current ground-water work: Akin $\mathbf{5 0}$

Areal reports.

Aneta area, Nelson County: Dennis $47 \mathrm{~b}$

Buxton area, Traill County: Dennis 47a

Cass County: Dennis 49b

Clay County: Dennis 49b 
North Dakota-Continued

Crosby quadrangle, Divide County: LaRocque 54b

Devils Lake area: Akin 51b

Dickinson, Stark County: MeLaughlin 46b; Tychsen 50

Fairmont area, Richland County: Paulson 53

Fargo area, Cass County: Byers 46

Fessenden area, Wells County: Filaseta 46

Fort Berthold Indian Reservation: Dingman 54a

Heart Valley, Burleigh, Morton, and Grant Counties: Tychsen 50

Hope area, Steele County: Dennis $48 \mathrm{~b}$

Kindred area, Cass and Richland Counties: Dennis 50b

Litchville area, Barnes County: Akin 52a

Michigan City area, Nelson County: Aronow $53 \mathrm{~b}$

Minnewauken area, Benson County: Aronow $53 a$

Minot area, Ward County: Akin 47

Mohall area, Bottineau and Renville Counties: Akin 51a

Mountain area, Pembina County: Akin 46

Neche area, Pembina County: Paulson 51

Noonan quadrangle, Divide County: LaRocque 54a

Oakes area, Dickey County: Rasmussen $47 \mathrm{~b}$

Portal quadrangle, Burke County: LaRocque $54 \mathrm{c}$

Portland area, Traill County: Dennis 50a

Sharon area, Steele County: Dennis $47 \mathrm{c}$

Stanley area, Mountrail County: Paulson 55

Streeter area, Stutsman, Logan, and Kidder Counties: Paulson 52

Wimbledon area, Barnes and Stutsman Counties: Dennis 48a

Wyndmere area, Richland County: Dennis $49 \mathrm{a}$

Zeeland area, McIntosh County: Laird, W. M., 48

Geologic maps.

Aneta area: Dennis 47b

Fort Berthold Indian Reservation: Dingman 54 a

Kindred area: Dennis $50 \mathrm{~b}$

Litchville area: Akin 52a

Lower Heart River valley: Tychsen 50

Michigan City area: Aronow 53b

Minnewauken area: Aronow 53a

Mohall area: Akin 51a

Oakes area: Rasmussen 47b

Sharon area: Dennis $47 \mathrm{c}$

Stanley area: Paulson 55

Streeter area: Paulson 52

Wimbledon area: Dennis $48 \mathrm{a}$

Wvndmere area: Dennis $49 a$
North Dakota-Continued

Hydraulics of aquifers.

Cretaceous (?) sand, Portland: Dennis 50a

Fort Union formation, Dickinson: McLaughlin $46 \mathrm{~b}$

Glacial drift, Fargo: Dennis 49b

Glacial lake deposits, Oakes: Rasmussen $47 \mathrm{~b}$

Glacial outwash, Michigan City: Aronow $53 \mathrm{~b}$

Souris Valley at Minot: Akin 47

Zeeland: Laird, W. M., 48

Lake Agassiz deposits, Fargo: Dennis 49b

Kindred: Dennis 50b

Pierre shale, Michigan City: Aronow 53b

Hydrologic maps.

Fairmont area: Paulson 53

Fort Berthold Indian Reservation: Dingman 54a

Mountain area: Akin 46

Neche area: Paulson 51

Oakes area: Rasmussen $47 \mathrm{~b}$

Zeeland area: Laird, W. M., 48

Public water supplies.

Lohr 54b

Quality of water.

Public supplies: Lohr 54b

Water-level measurements.

See fig. 1; table 1 Ohio.

Bedrock surface, Ada area: Walton $\mathbf{5 3}$

Montgomery County: Norris 48b

West-central Ohio: Norris 51

Significance of water-level data: Schaefer $46 \mathrm{a}$

Areal reports.

Ada area, Hardin County: Walton 53

Butler County: Bernhagen 47

Canton area, Stark County: Schaefer $46 \mathrm{~b}$

Cincinnati area, Hamilton and Butler Counties: Klaer $48 \mathrm{c}$

Clark County: Norris 52b

Cuyahoga County: Winslow, J. D., 53

Greene County: Norris $\mathbf{5 0}$

Hamilton County: Bernhagen 47

Mahoning River basin: Cross 52

Montgomery County: Norris 48a

Steubenville area, Jefferson County: Smith, R. C. 55

Summit County: Smith, R. C. 53

Tuscarawas County: Cummins 47

Youngstown area, Mahoning County: Cross 52

Geologic maps.

Canton area: Schaefer $46 \mathrm{~b}$

Clark County: Norris 51, 52b

Cuyahoga County: Winslow, J. D., 53

Greene County: Norris 50, 51

Madison County: Norris 51

Montgomery County: Norris 48a, 51

Summit County: Smith, R. C., 53

Tuscarawas County: Cummins 47

Youngstown area: Cross 52

Geophysical surveys. 


\section{Ohio-Continued}

Resistivity, Cuyahoga County: Winslow, J. D., 63

Hydraulice of aquifers.

Outwash gravel, west of Canton: Schaefer $46 \mathrm{~b}$

Tymochtee dolomite, Ada: Walton 63

Hydrologic maps.

Clark County: Norris $62 b$

Cuyahoga County: Winslow, J. D., 63

Greene County: Norris $\mathbf{5 0}$

Hamilton area, Butler County: Bernhagen 47

Ohio: Cross 49

Summit County: Smith, R. C., 53

Youngstown area: Cross $\mathbf{6 2}$

Public water supplies.

Lohr 54 a

Quality of water.

Public supplies: Lohr 64a

Water-level measurements.

See fig. 1; table 1

Ground-water levels, 1938-46; Van Tuyl

47.
1947: Van Tuyl 48
1948: Kaser 60
1949-50: Kaser 62
1951-52: Kaser 64

Okinawa.

Southern Okinawa: Cederstrom 47a

Geologic map.

Southern Okinawa: Cederstrom 47a

Oklahoma.

Aquifers in Ottawa County: Reed, E. W., $52 b$

Origin of Drummond Flat, Garfield County: Barclay 62

Pumpage and water levels in the Panhandle: Schoff 53

Unusual fluctuations in Rush Springs wells: Reed, E. W., 49

Areal reports.

Cherokee area, Alfalfa County: Schoff 50a

Cimarron Terrace, Alfalfa, Garfield, Kingfisher, and Major Counties: Reed, E. W., $52 \mathrm{a}$

Duke area, Jackson and Greer Counties: Reed, E. W., 50; Schoff 48

Fort Gibson flood plain, Muskogee County: Schoff 51b

Grady County: Davis, I. V., 55

Kingfisher County: Schoff 49a

Lake Hefner area: Dennis 54

Oklahoma City area: Jackson 49

Ottawa County: Reed, E. W., 55

Pond Creek basin, Caddo County: Davis, L. V., 50

Terrace deposits, northeast side of Cimarron River: Reed, E. W., 52a

Tillman County, western: Barclay 53

Geologic maps.

Bethany area, Oklahoma County: Jacobson 49

Cimmaron Terrace: Reed, E. W., 52a
Oklahoma-Continued

Fort Gibson flood plain: Schoff $51 \mathrm{~b}$

Grady County: Davis, L. V., 55

Ottawa County: Reed, E. W., 55

Stephens County: Davis, L. V., 55

Tillman County: Barclay $\mathbf{5 3}$

Hydraulics of aquifers.

Alluvium, Arkansas Valley at Fort Gibson: Schoff 51c

Flood plain near Fort Gibson: Schoff 51b

North Canadian Valley, near Fl Reno: Schoff 51c

Near Oklahoma City: Schoff 61c

Canadian series (Arbuckle group), near Miami: Reed, E. W., 55

Ottawa County: Reed, E. W., 55

Cimmaron Terrace deposits, Enid: Reed, E. W., 62a

Duncan sandstone, Grady County: Davis, L. V., 55

Permian strata, Enid: Reed, F. W., 52a Rush Springs sandstone, Grady County: Davis, L. V., 65

Pond Creek basin: Davis, L. V., 50

Terrace deposits, Chickasha: Davis, L. V., 55

Tillman County: Barclay 63

Hydrologic maps.

Arkansas-White-Red River basins: Loh$\operatorname{man} 53 \mathrm{~d}$

Cimarron Terrace: Reed, E. W., 52a

Fort Gibson flood plain: Schoff $51 b$

Lake Hefner area: Dennis 54

Oklahoma: Schoff $\mathbf{6 5}$

Tillman County: Barclay 63

Public water supplies.

Description and chemical quality: Laine 51; Lohr 54b

Quality of water.

Geologic control: Walling 51

Public supplies: Laine 51; Lohr 54b

Water-level measurements.

See fig. 1; table 1

Oklahoma Panhandle: Schoff $49 \mathrm{~b}$

Tillman County: Reed, E. W., 47 Oregon.

Ground-water situation: Newcomb 51a

Areal reports.

Lake County (tabular data): Trauger 50

Swan Lake-Yonna Valley area, Klamath County: Meyers 62

Walla Walla basin, Umatilla County: Newcomb 51b

Geologic maps.

Lake County: Trauger $\mathbf{5 0}$

Walla Walla basin: Neweomb $\mathbf{5 1 b}$

Hydrologic maps.

Swan Lake-Yonna Valley area: Meyers 52

Public water supplies.

Lohr 54b

Quality of water.

Public supplies: Lohr 54b 
Oregon-Continued

Water-level measurements.

See fig. 1; table 1

Pacific Islands.

Angaur, Palau Islands: Wentworth $\mathbf{5 5}$

Falalop Island, Ulithi Atoll: Schlanger 55

Guadalcanal: Baker, R. C., 50

Hawaii Island: Stearns, H. T., 46

Ifalik Atoll: Arnow 55

Iwo Jima: Swenson, F. A., 48

Marshall Islands, northern: Arnow 54

Molokai Island: Maedonald 47b

Niihau Island: Stearns, H. T., 47

Particle-size analyses. See Physical properties of sediments.

Pennsylvania.

Availability of ground water in lower Delaware basin: Barksdale 53

Ground water, air-conditioning use at Pittsburgh: Van Tuyl 51a, 51b

Collection and development methods: Adamson 47

Problems: Graham 51a

Triassic area: Graham $\mathbf{4 5}$

Valley-fill deposits, Pittsburgh: Van Tuyl 50

Hydrologic interpretation, maps of Hollidaysburg quadrangle: Thomas 53d

Relation, geology to water quality: Graham 49

Water resources and water uses: Graham $50 \mathrm{~b}$

Water under P'enn's woods: Graham 47

Water use, 1951: Mangan 53

Areal reports.

Allegheny County: Adamson 49b; Noecker 54

Beaver County: Van Tuyl 51e

Bucks County: Greenman 55

Southeastern: Graham 51b

Delaware River valley: Barksdale 53, 55a

Lake Erie shore region, Erie County: Mangan 52

Lansdale area, Montgomery County: Rima 55

Philadelphia area: Graham 50a

Pittsburgh area: Adamson 49a; Noecker 54

Geologic maps.

Pittsburgh Triangle area: Adamson 49a; Noecker 54; Van Tuyl 51a

Southeastern Bucks County: Graham 51b

Geophysical surveys.

Well logging, Lansdale area: Rima 55

Hydraulics of aquifers.

Glacial outwash, Ohio Valley at Ambridge: Van Tuyl 51c

Hydrologic maps.

Hollidaysburg quadrangle: Thomas 53d

Lansdale area: Rima 55

Pittsburgh Triangle area: Noecker 54; Van Tuyl 51a
Pennsylvania-Continued

Southeastern Bucks County: Graham 51b

Water use, 1951: Mangan 53

Public water supplies.

Lohr 54a

Quality of water.

Bucks County, southeastern: Graham 51a

Lake Erie shore region: Mangan 52

Public supplies: Lohr 54a

Water-level measurements.

See fig. 1; table 1

Ferennial yield. See Yield.

Permafrost.

Occurrence and development of groundwater in permafrost regions: Cederstrom 53

Permafrost and ground-water, Alaska: Hopkins 55

Permeability.

Darcy's Law: Jacob 46a

Laboratory determination: Smith, W. 0 ., 55

Permeability coefficient and its units: Fishel 46

Reduced by trapped gases: Smith, W. O., 55

Report, Subcommittee on Permeability: Jacob $46 \mathrm{c}$

Selected bibliography: Johnson, A. I., 55

Permeameter. See Equipment.

Phreatophytes.

Areas and use of water, western United States: Robinson, T. W., 49b, 52a, $52 b, 53 b$

Developments and problems: Robinson, $T$. W., $52 \mathrm{e}, 54$

Use of water, Maricopa County, Ariz.: Turner 52

Lower Safford Valley, Ariz.: Gatewood 50

Physical properties of sediments and rocks.

Kentucky, Ohio Valley alluvium: Rorabaugh 46a, 48

Lake Superior district, rocks: Stuart 54

Nebraska, mantle-rock materials: Sniegocki 55

Wyoming, North Park formation: Visher 52

Slope wash: Visher 58

Piezometer. See Equipment and Methods of investigation.

Pollution. See Contamination of ground water. Precipitation.

Relation to ground water, Wisconsin: Drescher 55

Southwestern United States: Thomas 54

Primary water. See Juvenile water.

Public water supplies. See also under states.

United States, eastern: Lohr 54a

Western: Lohr 54b

Puerto Rico.

MeGuinness $47 \mathrm{~b}, 48$ 
Pumping costs.

Southwestern Utah: Nelson 54

Pumping tests. See Hydraulics of aquifers for theory, and subheading of $\mathrm{Hy}$ draulics of aquifers under States.

Quality of water. See also Geochemistry.

Relation to depth: Goines 51

Relation to stream flow: Durum 53

United States: Lohr 54a, 54b

Quicksand.

Ground-water problems in highway construction: Rasmussen 53

Research needs.

Balanced water-information program: Piper 63a

Closed basins: Thomas 51b

Colorado: McLaughlin 53

Comprehensive basic-data program: Sayre $53 \mathrm{c}$

Cyclic storage: Poland 50

Geochemistry of ground water: Hem 60

Ground-water hydrology: Meinzer $47 \mathbf{a}$

Ground-water problems of the West, needed investigation: White, W. N., 46

Ground-water storage facilities: Thomas $52 a$

Missouri River basin: Taylor, G. H., 51

Nebraska: Taylor, G. H., 52b

Nevada: Robinson, T. W., 53a

Radioactive wastes, disposal in wells: Theis $\mathbf{5 5}$

Rejected recharge: Broadhurst, W. L., 53 Reviews.

Geology and ground-water resources, Island of Hawaii: Cederstrom 47c

Grundwasserkunde: Schneider 51

Water-a study of its properties, its constitution, its circulation on the earth, and its utilization by man: Sayre $53 \mathrm{~b}$

Rhode Island.

Ground-water investigations: Allen $51 b$, $53 \mathrm{~b}$

Yield, rock wells: Cushman, R. V., 53b Areal reports.

Bristol quadrangle, Bristol County: Bierschenk 54

Bristol, Warren, and Barrington, in Bristol County: Allen 50b

Exeter area, Washington County: Allen $48 \mathrm{~b}$

Georgiaville quadrangle, Providence County: Allen 51a

Pawtucket quadrangle, Providence County: Allen 48a

Providence: Jeffords $48 \mathrm{~b}$

Rhode Island: Allen $\mathbf{5 3 a}$

Woonsocket, Providence County: Allen $50 \mathrm{a}$

Geologic maps.

Bristol quadrangle: Bierschenk 54

Bristol, Warren, and Barrington: Allen $50 \mathrm{~b}$

Exeter area: Allen 48b

Georgiaville quadrangle: Allen 51a
Rhode Island-Continued

Pawtucket quadrangle: Allen 48a

Woonsocket: Allen 48a

Hydraulics of aquifers.

Glacial outwash, Ashton: Allen 48a

Barrington: Bierschenk 54

Exeter: Allen 48b

Near Mashapaug Pond: Jeffords 48b

Public water supplies.

Deseription and chemical quality: Lohr $54 \mathrm{a}$

Survey of public ground-water supplies: Brashears $49 b$

Quality of water.

Public supplies: Lohr 54a

Water-level measurements.

See fig. 1; table 1

Safe yield. See Yield.

Saline water.

Brackish water, structural implications, Great Carolina ridge, North Carolina: LeGrand $55 \mathbf{a}$

Salt-water encroachment.

Bibliography: Winslow, A. G., 53

California, Los Angeles County: Poland 46, 48; Piper 53b

Orange County: Poland 46, 47; Piper $53 \mathrm{~b}$

Encroachment, salt water into fresh: Parker 55b

Florida: Parker 55a

Pinellas County: Heath $54 \mathrm{~b}$

Southeastern: Parker 55c

Induced by excavation: Wentworth $\mathbf{5 5}$

Louisiana, Baton Rouge: Meyer, R. R., $55 b$

Maryland, Baltimore area: Bennett $\mathbf{6 2}$

New York, Brooklyn: Lusczynski 52

Texas, Galveston County: Petitt 55

Harris County: Winslow, A. G., 54a

Tide-induced: Parker 55c

Salvador, El.

Sayxe 51

Salvage of water.

Phreatophyte control: Robinson, T. W., 52c, 54

Pumping, Sevier Desert, Utah: Nelson 53

Saudi Arabia.

Ground-water in the Nejd: Bramkamp 48

Sedimentation and ground-water.

Foley 50

Size grade. See Particle size.

Soil analysis data.

Wyoming, Torrington demonstration area: Visher 63

Soil moisture.

Relation to land-management practices: Barksdale $\mathbf{5 5 b}$

Solution depressions in diorite.

LeGrand $52 a$

South Carolina.

Streamlining of the Carolina bays: Le Grand $63 \mathbf{a}$ 
South Carolina-Continued

Water resources: South Carolina Development Board 55

Areal reports.

Piedmont and Coastal Plain provinces: Siple 46

Public water supplies.

Lohr 54a

Quality of water.

Fluoride in ground-water: Siple 46

Public supplies: Lohr 54a

Water-level measurements.

See fig. 1; table 1

South Dakota.

Areal reports.

Angostura irrigation project, Fall River and Custer Counties: Littleton 49

Lower Grand River valley, Corson and Perkins Counties: Tychsen $\mathbf{5 5}$

Rapid Valley unit, Pennington County: Rosier 53

Sioux Falls area, Minnehaha County: Rothrock 47

Geologic maps.

Angostura irrigation project: Littleton $\mathbf{4 9}$ Lower Grand River valley: Tychsen 55 Minnehaha County: Rothrock $\mathbf{4 7}$

Hydraulics of aquifers.

Sand and gravel, Sioux Falls: Rothrock 47

Public water supplies.

Lohr 54b

Quality of water.

Public supplies: Lohr 54b

Water-level measurements.

See fig. 1; table 1

Specific capacity.

Collector-type well: Rorabaugh 51

Variation with discharge, well radius, and time: Jacob 47; Rorabaugh 49c, $53 a$

Specific permeability. See Deflnitions.

Specific yield.

Determined from equilibrium test data: Remson 55c

Springs.

Florida: Ferguson, G. E., 47

Cessation of flow of Kissengen Spring: Peek 51

Submarine artesian spring off coast: Stringfield $\mathbf{5 1 c}$

Nevada, Steamboat Springs, geochemical results: Brannock 48

Sources of heat, water supply, and mineral content: White, D. E., 48,50

Thermal-spring classiflcation: White, D. E,. $\mathbf{5 3}$

Stream flow decreased by ground-water pumpage.

Hale, W. E., 55

Structural control of occurrence.

Fault zone as ground-water barrier: Poland 46

Faulting: Thomas 48
Struetural control of occurrence-Continued

Flow in vertical and inclined aquifers: Stuart 48

Limestone solution features: Hamilton 48 North Carolina, Great Carolina Ridge: LeGrand $55 \mathrm{a}$

Oklahoma, Ottawa County: Reed, E. W., 55

Rio Grande graben: Spiegel 55

Sheet structure in granite: LeGrand 49

United States: Thomas 55c

Utah, Cedar City and Parowan Valleys: Thomas $46 \mathrm{c}$

Subsidence.

Due to pumpage: Petitt 55; Winslow, A. G., 54b

Solution depressions in diorite: LeGrand $52 a$

Subsurface dams.

Ferris 54

Surface water-relation to ground-water.

California, effect of earthquake on spring and stream flow: Briggs $\mathbf{5 5}$

Colorado, hydrologic reconnaissance, Green River: Thomas 52c, 53a

Kansas, North Fork Solomon River: Leonard 52

Pawnee Valley: Fishel 52b

New Mexico, Dona Ana County: Conover 54

Spring flow related to pumpage: Fale, W. E., 55

Stream flow reduced by ground-water pumpage: Hale, W. E., $\mathbf{5 5}$

Texas, relation of ground-water to discharge of Leona River: Livingston $47 a$

Relation of surface and ground-water: Twichell 54

Utah, Echo Park reservoir: Thomas 52b

Hydrologic reconnaissance, Green River: Thomas 52c, 53a

Washington, rise in level of Soap Lake: Mundorff 54

Temperature.

Change with induced infiltration: Rorabaugh 51

Control by artificial recharge: Cederstrom 47b; Guyton; 46; Rorabaugh 49b

Effect on fiow: Eisenlohr 48

Relation to viscosity: Meyer, R. R., 55b; Rorabaugh $\mathbf{5 1}$

Soil temperature computation: Langbein 49

Studies, Louisville, Ky.: Rorabaugh 49b

Schenectady, N. Y.: Simpson, E. S., 52

Temperature of equilibrium, computation: Simpson, E. S., 52

Temperature gradient, Baton Rouge, La.: Meyer, R. R., $\mathbf{5 5 b}$

Use to determine connection between aquifer and river: Rorabaugh 48 Tennessee.

Ground-water in the upper Mississippi Embayment: Schneider 47 
Tennessee-Continued

Origin of limonite in Eocene beds: Schneider 49

Areal reports.

Shelby County: Schneider 48

Upper Mississippi Embayment: Schneider 47

Geologic maps.

Memphis area: Schneider 48

Middle Tennessee: Newcome 54

Western Tennessee: Stearns, R. G., 65

Geophysical surveys.

Electric logs, western Tennessee: Stearns, R. G., 55

Hydraulies of aquifers.

Sand, "1,400-foot", Memphis: Schneider 48

Public water supplies.

Description and chemical quality: Lohr $54 a$

Western Tennessee: Lanphere $\mathbf{5 5}$

Quality of water.

Public supplies: Lohr 54a

Western Tennessee: Lanphere $\mathbf{5 5}$

Subsurface correlations.

Western Tennessee: Schneider 50; Stearns, R. G., $\mathbf{5 5}$

Memphis area: Schneider 48

Water-level measurements.

See fig. 1; table 1

Terraces. Texas.

Problems in mapping: Frye 54

Artificial recharge at El Paso: Sundstrom $52 b$

Conservation of ground-water supplies: Sundstrom 47

Edwards limestone aquifer in San Antonio area: Lang, J. W., $\mathbf{5 4}$

Ground-water development in the southern High Plains: Leggat 54a

Ground-water for irrigation: Broadhurst, W. L., 51a

Ground-water hydrology: Broadhurst, W. L., 54

Ground-water resources: Sundstrom 55

Southern region: Sundstrom $48 \mathrm{a}$

Ground-water in Trinity group, Bexar County: Lang, J. W., 53

Interrelation, surface and ground-water: Twichell 54

Irrigation supply, Lobo Flats area: Hood 51

Outlook for ground-water resources: Sundstrom $\mathbf{5 4}$

Pumpage and decline of artesian pressure, Houston district, 1950-51: Winslow, A. G., 52

1951-52: Doyel 54

Recharge of aquifers: George 52b

Relation of ground-water to flow of Leona River: Livingston 47 a

Salt-water problem: George $\mathbf{5 0}$

Subsidence due to pumpage: Winslow $54 \mathrm{~b}$
Texas-Continued

Tide-producing forces and artesian pressures: George $51 \mathrm{~b}$

Water supply of the Houston Gulf Coast region: Goines 51

Areal reports.

Atascosa County: Sundstrom 50

Bastrop County (tabular data): Austin 54

Bexar County: Livingston $47 \mathrm{~b}$

Borden County: Ellis 49

Brazoria County: Follett 47

Briscoe County (tabular data): Dante 46

Caldwell County: Rasmussen 47a

Cameron County: Dale 54

Comal County: George 48, 52a

Dell City area, Hudspeth County: Scalapino 50

Ector County: Knowles $\mathbf{5 2}$

El Paso area, El Paso County: Scalapino 49

Floyd County (tabular data): Follett 46

Fort Worth area, Tarrant County: George 42

Galveston County: Petitt 55

Gregg County: Broadhurst, W. L., 50a

Harris County: Winslow, A. G., 54a

Hays County (tabular data): DeCook 55

High Plains: Barnes, J. R., 49; Broadhurst, W. E., 46; Gaum 53; Leggat $51,54 a, 54 b$

Houston district, Harris County: Doyel 54; Lang 46, 50; Winslow, A. G., 52

Houston Gulf Coast region: Broadhurst, W. L., 53; Goines 51

Jones County: Winslow, A. G., 54c

Kenmore Farms, Kendall County: George 52c

La Tuna, El Paso County: Sundstrom 52a

Liberty County: Alexander $\mathbf{5 0}$

Linn district, Hidalgo County: George 47

Linn-Faysville area, Hidalgo County: Follett 49

Llano Estacado: Gaum 53

Lobo Flats area, Culberson and Jeff Davis Counties: Hood 51

Lynn County: Leggat 52

Matagorda County: Sundstrom 49b

Mitchell County: Dale 53

Nolan County, northwestern: Knowles $47 \mathbf{a}$

Odell sand hills, Wilbarger County: Willis 53

Parker County: Stramel 51

Pecos area, Reeves and Ward Counties: Hood 52

Pecos County, northern (tabular data): Dante 47

Reeves County: Knowles $47 \mathrm{~b}$

San Jacinto County: Alexander 47

Sourry County: Knowles 46

Sherman, Grayson County: Livingston 45

Starr County: Dale 52

Tom Green County: Willis 54 


\section{Texas-Continued}

Waco, McLennan County: George 45

Walker County: Winslow, A. G., 50

Waller County: Fluellen 52

Waxahachie, Ellis County: Sundstrom $48 \mathrm{~b}$

Wharton County: Barnes, J. R., 48

Winter Garden district: Outlaw 52

Geologic maps.

Caldwell County: Rasmussen 47a

Comal County: George 52a

Galveston County: Pettit $\mathbf{5 5}$

Harris County: Winslow, A. G., 54a; Sundstrom 54

Odell sand hills: Willis 53

Parker County: Stramel 51

Tom Green County: Willis 54

Winter Garden district: Outlaw 52

Geophysical surveys.

Electric logs, Cameron County: Dale 54

Galveston County: Petitt $\mathbf{5 5}$

Harris County, Winslow, A. G., 54a

Houston: Lang, J. W., 50

Starr County: Dale 52

Walker County: Winslow, A. G., 50

Waller County: Fluellen 52

Wharton County: Barnes, J. R., 48

Hydraulics of aquifers.

Alluvium of Rio Grande Valley, La Tuna: Sundstrom 52a

"Alta Loma" sand, Alta Loma area: Petitt 55

Beaumont clay, Texas City area: Petitt 55

Bolson deposits, El Paso: Scalapino 49; Sundstrom $52 b$

Coastal Plain sediments, Houston: Rorabaugh $49 \mathrm{c}$

Paluxy sand, Sherman: Livingston $\mathbf{4 5}$

Quaternary sand, Houston: Lang, J. W., 46,50

Seymour formation, Odell sand hills: Willis 53

Travis Peak formation (Trinity group), Waco: George $\mathbf{4 5}$

Trinity sand, Waxahachie: Sundstrom $48 \mathrm{~b}$

Woodbine sand, Sherman: Livingston 45

Hydrologic maps.

Arkansas-White-Red River basins: Loh$\operatorname{man} 53 d$

Comal County: George 52a

Ector County: Knowles $\mathbf{5 2}$

Galveston County: Petitt $\mathbf{5 5}$

Harris County: Winslow, A. G., 54a

High Plains: Barnes, J. R., 49; Leggat 51, 54a, 54b; Sundstrom 54

Houston district: Doyel 54; Lang, J. W., 46; Sundstrom 54

Odell sand hills, Wilbarger County: Willis 53

Pecos area: Hood 52

San Antonio area: Lang, J. W., 54

Waller County: Fluellen 52
Texas-Continued

Public water supplies.

Central and north-central: Sundstrom $49 \mathrm{a}$

Description and chemical quality: Lohr $54 \mathrm{~b}$

Eastern: Sundstrom $48 \mathrm{c}$

Southern: Broadhurst, W. L., $50 b$

Western: Broadhurst, W. L., 51b

Quality of water.

Comal County: George $52 a$

Description and chemical quality: Lohr $54 \mathrm{~b}$

El Paso area: Scalapino 49

Graph of quality relations, Galveston County: Pettit 55

Nitrate in ground water: George $\mathbf{5 1 a}$

Public supplies: Lohr 54b

Public supplies, eastern: Sundstrom 48c

Southern: Broadhurst, W. L., 50b

Western: Broadhurst, W. L., 51b

Public water supplies, central and northcentral: Sundstrom $49 a$

Salt-water encroachment, El Paso: Scalapino 49

Temperature, hardness, chloride, and dissolved solids versus depth: Goines 51

Water-level measurements.

See fig. 1; table 1

Atascosa County: Swartz 54

Bailey County: Follett 54c

Bastrop County: Austin 54

Bexar County: Livingston $47 \mathrm{~b}$

Briscoe County: Follett $54 \mathrm{c}$

Castro County: Follett 54c

Cochran County: Follett 54d

Comal County: George 52a

Crosby County: Follett 54d

Culberson County: Follett $54 \mathrm{~g}$

Dallam County: Follett 54a

Deaf Smith County: Follett 53c

El Paso County: Follett 54h

Floyd County: Follett 53d

Frio County: Swartz 54

Gaines County: Follett 54d

Hale County: Follett 53a

Hansford County: Follett 54a

Hartley County: Follett $54 \mathrm{a}$

Haskell County: Follett 55

High Plains: Broadhurst, W. L., 46

Hockley County: Follett 54d

Houston district: Lang, J. W., 46

Hudspeth County: Follett $54 \mathrm{~g}$

Hutchinson County: Follett 54a

Jeff Davis County: Follett $54 \mathrm{~g}$

Knox County: Follett 55

Lamb County: Follett 53e

Loving County: Follett 54e

Lubbock County: Follett 53b

Lynn County: Follett 54d

Martin County: Follett 54b

Moore County: Follett 54a

Ochiltree County: Follett 54a

Parmer County: Follett 54c 
Texas-Continued

Potter County: Follett 54c

Randall County: Follett 54c

Reeves County: Follett $54 f$

Sherman County: Follett 54a

Swisher County: Follett $53 \mathrm{f}$

Terry County: Follett 54d

Ward County: Follett 54e

Wharton County: Barnes, J. R., 48

Winter Garden district: Outlaw $\mathbf{5 2}$

Thermal water.

California, Lake City Hot Springs: White, D. E., 55

Classification of thermal springs: White, D. E., 53

New Mexico, Hot Springs artesian basin: Theis 42

Nevada, Steamboat Springs: Brannock 48: White, D. E., 48, 50

Tracing ground-water flow.

Mine water, East Tennessee zinc district: Kent 50

New Mexico, Rito Resumidera to Poleo Canyon Spring: Hollander 54

Transmissibility. See Hydraulics of aquifers. Ulithi Atoll.

Falalop Island: Schlanger $\mathbf{5 5}$

United States.

Artesian water, southeastern states: Stringfield 53

Bibliography of ground-water publications: Waring 47

Drought in Southwest, 1942-53: Thomas 54

Ground water, Western States: White, W. N., 46

Ground-water conditions: MeGuinness 51a

Geology, southeastern States: Stringfleld 50

Oceurrence and movement: Thomas $55 \mathrm{~b}$ Oceurrence and utilization: Thomas $55 \mathrm{c}$

Regions and their storage facilities: Thomas 52a

Situation: Parker 49

Use: Graham 52

For public supply, New England: Brashears $49 \mathrm{~b}$

High Plains: Lohman 53b

Missouri River basin: Taylor, G. H., 51, $53 a$

Need of comprehensive basic-data program for water resources: Sayre 53c

Potential ground-water irrigation, Missouri River basin: Taylor, G. H., 53a

Predicitions of water use: Piper 53a

Scientiflc management of ground-water resources: Meinzer $47 \mathrm{~b}$

Underground sources of water: Thomas $55 b$

Water law: McGuinness 51b

Water levels, observation wells: See fig. 1; table 1
United States-Continued

Water situation: McGuinness $\mathbf{5 1 a}$

Water use 1945: Guyton 49

1950: Mackichan 51; Piper 53a

Hydrologic maps.

Areas, artesian flows in southeastern States: Stringfield 53

Heavy ground-water use: Parker 49

Intensive ground-water investigation: Parker 49

Substantial ground-water information: MeGuinness 51a

Ground-water areas: McGuinness 51a; Thomas $55 \mathrm{~b}$

Reservoirs with perennial overdraft: Thomas 55b

Use, 1945, municipal, industrial, and total: McGuinness 51a

Use for irrigation: McGuinness $\mathbf{5 1 a}$

Significant cones of depression: Thomas $55 b$

Water used, in 1950, for domestic and stock, municipal, industrial, irrigation, and water-power supplies: MacKichan 51

Public water suppliee.

East of the Mississippi: Lohr 54a

New England: Brashears 49b

West of the Mississippi: Lohr 54b Utah.

Artificial recharge at Bountiful: Thomas $49 \mathrm{~b}$

Deep water wells, Utah County: Thomas $52 d$

Effect of drought, Cedar City Valley: Waite $\mathbf{5 5}$

Evapotranspiration, Ashley Valley: Thomas $52 f$

Fluctuations of ground-water levels, 198645: Thomas 46a

Navajo Country: Harshbarger 53

Pumping costs: Nelson 54

Pumping from wells, Sevier Desert floor: Nelson 53

Reconnaissance studies, Green River: Thomas 53 a

Status of development, selected groundwater basins: Thomas 52e

Water resources, northern Utah valley: Thomas 53e

Areal reports.

Cedar City Valley, Iron County: Thomas 46e; Waite 55

East Shore area, Bountiful district, Davis County: Thomas 48, 49b

Echo Park reservoir: Thomas 52b

Escalante Valley, Beaver, Iron, and Washington Counties: Fix $\mathbf{5 0}$

Green River reconnaissance: Thomas 52c

Jordan Valley, Salt Lake County: Taylor, G. H., 49

Navajo and Hopi Indian Reservations: Halpenny 51; Harshbarger 53

Ogden Valley: Lofgren 55 
Utah-Continued Parowan Valley, Iron County: Thomas

Pavant Valley, Millard County: Dennis 46

Southeastern: Lofgren 54

Southwestern: Waite 64

Tooele Valley, Tooele County: Thomas $46 \mathrm{~b}$

Weber Basin: Feth 64a

Geologic maps.

Beryl-Enterprise district: Fix $\mathbf{5 0}$

Blanding-Montezuma Valley area: Lofgren 54

Cedar City Valley: Thomas 46c

East Shore area, Bountiful district: Thomas 48

Parawan Valley: Thomas 46c

Pavant Valley: Dennis 46

Tooele Valley: Thomas 46b

Hydraulies of aquifers.

Pre-Lake Bonnerville deposits, Topaz: Nelson 53

Stream and lake deposits, Jordan Valley: Taylor, G. H., 49

Hydrologic maps.

Beryl-Enterprise district: Fix 50; Waite 54

Cedar City Valley: Thomas $46 \mathrm{c}$

East Shore area: Thomas 48

Milford district: Fix 50; Waite 54

Northern Utah Valley: Thomas 53c

Parowan Valley: Thomas $46 \mathrm{c}$

Topaz area: Nelson 63

Public water supplies.

Lohr 54b

Quality of water.

Public supplies: Lohr 54b

Water-level measurements.

See fig. 1; table 1

Southwestern: Waite 54

Vegetational use of ground-water. See Phreatophytes.

Vermont.

Public water supplies.

Description and chemical quality: Lohr $54 a$

Survey of public ground-water supplies: Brashears $49 \mathrm{~b}$

Quality of water.

Public supplies: Lohr 54a

Water-level measurements.

See fig. 1; table 1

Virgin Islands.

Areal reports.

St. Croix: Cederstrom $\mathbf{5 0}$

Geologic maps.

St. Croix: Cederstrom 50

Virginia.

Areal reports.

Eastern Shore peninsula: Sinnott 54, 55

Public water supplies.

Lohr 54a

Virginia-Continued

Quality of water.

Fluoride, Coastal Plain: Sinnott 60

Gasoline contamination, Arlington: Cederstrom $47 \mathrm{~d}$

Geochemistry, Coastal Plain aquifers: Cederstrom $46 \mathrm{a}, 46 \mathrm{~b}$

Public supplies: Lohr 54a

Water-level measurements.

See fig. 1; table 1

Viscosity. See Temperature.

Washington.

Rise in level of Soap Lake: Mundorff 64

Areal reports.

Adams County: Mundorfi $\mathbf{6 2}$

Columbia Basin project, Grant, Franklin, and Adams Counties: Mundorff 62 , 53

East Sound area, Orcas Island, San Juan County: Washburn 54

Franklin County: Mundorff 52

Grant County: Mundorff 52

Sammamish Lake area, King County: Liesch $\mathbf{5 6}$

Skagit County, southwestern: Sceva 50

Snohomish County: Newcomb 62

Spokane-Coeur d'Alene River basin: Simons 53

Spokane Valley, Spokane County: Weigle 52

Tacoma area, Pierce County: Sceva 55

Yelm area, Thurston and Pierce Counties: Mundorff $\mathbf{6 5}$

Walla Walla basin, Walla Walla County: Newcomb 51b

Geologic maps.

Columbia Basin project: Mundorff 52

Snohomish County: Newcomb 62

Soap Lake area: Mundorff 54

Southwestern Skagit County: Sceva 50

Walla Walla basin: Newcomb $51 b$

Yelm area: Mundorff $\mathbf{5 5}$

Geophysical surveys.

Seismic, Hillyard trough: Newcomb 63

Hydraulics of aquifers.

Pre-Vashon outwash, Orcas Island: Washburn 54

Hydrologic maps.

Columbia Basin project: Mundorff $\mathbf{5 2}$

Snohomish County: Newcomb 62

Soap Lake area: Mundorff 64

Spokane Valley: Weigle 52

Tacoma area: Sceva 55

Yelm area: Mundorfi 55

Public water supplies.

Lohr 54b

Quality of water.

Public supplies: Lohr 54b

Water-level measurements.

See fig. 1; table 1

Waste disposal.

Aquifers as waste-disposal reservoirs: Ferris $51 b$ 
Waste disposal-Continued

Artificial recharge of artesian limestone: Unklesbay 46

Atomic wastes: Warde $\mathbf{5 5}$

Geologic and hydrologic factors: Theis 55

Kansas, Wichita area: Williams 49

Louisiana, recharge of industrial ground water: Turcan $\mathbf{5 2}$

Pond drainage by wells: LaMoreaux 49a

Sprinkler irrigation: Barksdale $55 \mathrm{~b}$

Water-budget studies.

New Mexico, Rincon and Mesilla Valleys: Conover 54

New York, Broome County: Brown, R. H., 46

Storage equation: Ferris $\mathbf{4 9}$

Water levels.

Cyclic fluctuations used in caleulating transmissibility: Ferris $\mathbf{5 1 a}$

Effect, recharge and depletion: McGuinness $47 a$

Fluctuation interpretation: Fishel 55; Guyton 48; Thomas $51 \mathrm{a}$

Utah, 1936-45: Thomas 46a

Rise with cessation of pumping: Lusczynski 52

United States, water levels and artesian pressures, observation wells: See fig. 1; table 1

Wisconsin, relation to precipitation: Drescher $\mathbf{5 5}$

Barometric fluctuations.

Tide-producing forces and artesian pressures: George 51b

Tornadoes: Reed, E. W., 49

Utah: Taylor, G. H., 49; Thomas 46b

Winds and pressure changes: Parker 50 Earth-tide fluctuations.

Tide-producing forces and artesian pressures: George 51b

Utah: Thomas 46b

Measurement.

Air-line method: Lohman 54

Electric tape: de Laguna 53; Norris 52a

Methods: Guyton 48; Schoff 51a

Miscellaneous fiuctuations.

Factory machinery: Bennett 52

Ocean tides: P'arker $\mathbf{5 0}$

Trains: Parker 50

Seismic fluctuations.

Alabama wells: LaMoreaux 53a

California wells: Davis, G. H., 55

Florida wells: Parker 50

Interpretation: Vorhis 53, 55

Nebraska well: Taylor, G. H., 52a

United States, 1943; Bodle 45

1944: Bodle 46

1949: Murphy 51

1950: Murphy 52

1951: Murphy 53

1952: Murphy 54

1953: Murphy 55

Utah: Taylor, G. H., 49
Water use.

Air conditioning, Pittsburgh: Van Tuyl $51 \mathrm{a}$

Oil industry: Maher 51

Pennsylvania, 1951: Mangan 53

Phreatophytes, western United States: Robinson, T. W., 49b, 52b

United States, 1945: Guyton 49 1950: MacKichan 51

Well construction and maintenance.

Design of wells: Rorabaugh 48

Development of ground water in permafrost regions: Cederstrom 53

General: Jones, P. H., 54b

Geology and water-well construction: Schoff $50 \mathrm{~b}$

Incrustation, treatment: Carlston $\mathbf{5 5}$

River infiltration as a source of groundwater supply: Kazmann 48

Well-cleaning methods: Rasmussen $55 \mathrm{~b}$

Well efficiency. See Definitions.

Well exploration. See Well logging.

Well logging.

Pennsylvania, Lansdale area: Rima 55

Wagon-drill cuttings, sample collectors: Gordon 53

Caliper method.

Test wells: Bennett 52

Casing exploration.

Measuring casing length in wells: Norris 49

Electric. See also Electric-log interpretation. Bibliography: Richardson $\mathbf{5 0}$

West Virginia.

Ground water: Johnston, H. F., 49

Areal reports.

Charleston: Jeffords 46

Ohio River valley: Carlston 55

Wheeling area: Smith, R. C., 55

Hydraulics of aquifers.

Ohio Valley alluvium: Carlston 55

Public water supplies.

Lohr 54a

Quality of water.

Comparison of ground water with Ohio River water: Carlston $\mathbf{5 5}$

Public supplies: Lohr 64a

Water-level measurements.

See fig. 1; table 1

Wisconsin.

Ground-water studies: Foley 47

Areal reports.

Brown County: Drescher 53a

Green Bay area: Drescher 63a

Langlade County: Harder 54

Milwaukee-Waukesha area: Drescher 53b; Foley 53

Geologic maps.

Langlade County, southwestern: Harder 54

Milwaukee-Waukesha area: Drescher 53b; Foley 53

Geophysical surveys.

Resistivity, Antigo: Spicer 
Wisconsin-Continued

Hydraulics of aquifers.

Glacial outwash of Cary age, Antigo: Harder 54

Sandstone aquifer, Green Bay area: Drescher 53a

Milwaukee-Waukesha area: Foley 53

Hydrologic maps.

Brown County: Drescher 53a

Langlade County: Harder 54

Milwaukee-Waukesha area: Foley 53

Public water supplies.

Lohr 54a

Quality of water.

Public supplies: Lohr 54a

Water-level measurements.

See fig. 1; table 1

Wyoming.

Regularity of Old Faithful Geyser: Fix 49

Summary of ground-water resources of Laramie River drainage basin and North Platte River drainage basin: Bradley 55

Areal reports.

Cokeville area, Lincoln County: Berry 55

Egbert-Pine Bluffs-Carpenter area, Laramie County: Rapp 53c

Gillette area, Campbell County: Littleton $50 \mathrm{a}$

Glendo-Wendover area, Platte County: Rapp 53b

Horse Creek-Bear Creek area, Laramie and Goshen Counties: Babcock 52a

Laramie basin, Albany County: Littleton $50 \mathrm{~b}$

Laramie River drainage basin: Bradley $\mathbf{5 5}$

La P'rele area, Converse County: Rapp $53 \mathbf{a}$

Newcastle area, Weston County: Williams $48 \mathrm{~b}$

Paintrock irrigation project, Big Horn County: Swenson, F. A., 51

Pass Creek Flats area, Carbon County: Visher 52

Ranchester area, Sheridan County: Warner 46

Torrington demonstration area, Goshen County: Visher 53

Wheatland Flats area, Platte County: Littleton $50 \mathrm{c}$
Wyoming-Continued

Geologic maps.

Albany County: Littleton 50b

Cokeville area: Berry 55

Egbert-Pine Bluffs-Carpenter area: Rapp $53 \mathrm{c}$

Glendo-Wendover area: Rapp 53b

Horse Creek-Bear Creek area: Babcock $52 a$

La Prele area: Rapp 53a

Paintrock irrigation project: Swenson, F. A., 51

Pass Creek Flats area: Visher 52

Torrington demonstration area: Visher 53

Wheatland Flats area: Littleton 50c

Hydraulics of aquifers.

"Converse sand" of Hartville formation, Glendo-Wendover area: Rapp 53b

Hydrologic maps.

Egbert-Pine Bluffs-Carpenter area: Rapp $53 \mathrm{c}$

Torrington demonstration area: Visher 53

Public water supplies.

Lohr 54b

Quality of water.

Irrigation suitability, Glendo-Wendover area: Rapp 53b

Horse Creek-Bear Creek area: Babcock 52a

Water-level measurements. Yield.

See fig. 1; table 1

Perennial yield.

California, Santa Maria Valley: Worts 51

Delaware: Marine $\mathbf{5 5}$

Newark: Groot 54

Florida, Biscayne aquifer: Parker 51 Principal artesian aquifer: Stringfield 51a

Oklahoma, Tillman County: Barclay 53

Relation of bedrock yield to type of overburden: Simpson, E. S., 52

Relation of well depth, topographic location of well, and geology: Dingman $54 \mathrm{~b}$

Relation to topography: LeGrand 52c

Rock wells in New England: Cushman, R. V., 53b

Safe yield, Maryland, Baltimore area: Bennett 52 